\title{
A ECONOMIA POLÍTICA E OS CONTRATOS COLETIVOS DE TRABALHO NOS EUA, MÉXICO E BRASIL:
}

\section{ASPECTOS COMPARATIVOS}

Tese de Doutoramento apresentada ao Programa de Pós-Graduação do Departamento de História da Faculdade de Filosofia, Letras e Ciências Humanas da Universidade de São Paulo, para a obtenção do Título de Doutor em História Econômica.

Orientadora: Profa. Dra. A. Fernanda Pacca Wright 


\title{
A ECONOMIA POLÍTICA E OS CONTRATOS COLETIVOS DE TRABALHO NOS EUA, MÉXICO E BRASIL: ASPECTOS COMPARATIVOS
}

\author{
por \\ SÉRGIO MOTEJUNAS RAMOS
}

Tese de Doutoramento apresentada ao Programa de PósGraduação do Departamento de História da Faculdade de Filosofia, Letras e Ciências Humanas da Universidade de São Paulo, para a obtenção do Título de Doutor em História Econômica.

Orientadora: Profa. Dra. A. Fernanda Pacca Wright

Aprovada por

Dirigente da Comissão Fiscalizadora

Programa autorizado

para oferecer o título de:

Data 


\section{DEDICATÓRIA}

Ao meu primeiro, querido e saudoso mestre, Huberto Rohden, ad hominem:

Meu caro amigo,

Recebi tuas felicitações. Muito obrigado!

Atingi o 'vértice da pirâmide' dizes.

Enchi de mil conhecimentos o espírito - é verdade.

Cinge-me a fronte o laurel de doutor - sou acadêmico.

Entretanto - não me iludo...

Quase todo o humano saber - é crer...

Nossa ciência é fé.

Creio no testemunho dos historiadores - porque não presenciei o que referem.

Creio na palavra dos químicos e físicos - porque admiti que não se tenham enganado, nem me queiram enganar.

Creio na autoridade dos matemáticos e astrônomos - porque não sei medir uma só das distâncias e trajetórias siderais.

Tenho de crer em quase todas as teses e hipóteses da ciência - porque ultrapassam os horizontes da minha capacidade de compreensão.

Creio até nas coisas mais quotidianas - na matéria e na força que me circundam...

Creio em moléculas e átomos, em elétrons - que nunca vi...

Creio nas emanações do radium e nas partículas do helium - enigmas ultramicroscópicos.

Creio no magnetismo e na eletricidade - esses mistérios de cada dia.

Creio na gravitação dos corpos sidéreos - cuja natureza ignoro.

Creio no princípio vital da planta e do animal - que ninguém sabe definir.

Creio na própria alma - esse mistério dentro do Eu.

Não te admires, meu amigo, de que eu, formado em ciências naturais, creia piamente em tudo isto...

Admira-te antes que haja quem afirme só admitir o que compreende - depois de tantos anos de fé quotidiana.

O que me espanta é que homens que vivem de atos de crença descreiam de Deus - "por motivos científicos".

Homem! Tu, que não compreendes o artefato - pretendes compreender o Artífice?

Que Deus seria esse que em tua inteligência coubesse?

Um mar que coubesse numa concha de molusco - ainda seria mar?

Um universo encerrado num dedal - que nome mereceria?

$O$ infinito circunscrito pelo finito - seria infinito?

Convence-te, ó homem, desta verdade: só há duas categorias de seres que estão dispensados de crer - os da meia-noite - e os do meio-dia...

As trevas noturnas do irracional - e a luz meridiana da Divindade...

O insciente - e o onisciente...

Aquele, por incapacidade absoluta - este, por absoluta perfeição...

O que oscila entre a treva total do insciente e a luz integral do onisciente - deve crer...

Deve crer, porque a fé se move nesse mundo crepuscular, eqüidistante do vácuo e da plenitude, da meia-noite e do meio-dia...

(Huberto Rohden) 


\section{AGRADECIMENTOS}

À minha orientadora, Profa. Dra. A. Fernanda Pacca Wright, mestra extraordinária! Por ser a primeira a desvendar os árduos caminhos que ainda hoje me levam a sonhar, e a sentir-me capaz de oferecer modesta contribuição ao conhecimento. Agradeço-lhe pelo dinamismo, incentivo e o cultivo da liberdade essencial na busca do saber científico, independente das eventuais carências materiais ou espirituais. Pela dedicada orientação, tanto quanto pelos conhecimentos transmitidos. Obrigado, querida Mestra.

À prezadíssima Profa. Dra. M. Cristina Cacciamali que me conduziu primeiramente ao mundo acadêmico. Obrigado caríssima professora.

À Pró-Reitoria de Cultura e Extensão Universitária: Prof. Dr. Adilson Avansi de Abreu, nomeando-me representante discente no Conselho Deliberativo do Cinusp, pelo apoio à realização da pesquisa.

À Pró-Reitoria de Pesquisa, representada pelo Prof. Dr. Luiz Nunes de Oliveira, nomeando-me representante discente no NAPs (Núcleos de Apoio à Pesquisa), pelo incentivo indispensável à realização da pesquisa.

Ao Núcleo de Apoio à Pesquisa em Estudos Norte-Americanos (NAPENA), coordenado pela minha orientadora Profa. Dra. A. Fernanda P. Wright que disponibilizou a sala e recursos informacionais do Núcleo de Informática em Comunicações e Artes (NICA) na Escola de Comunicação e Arte (ECA).

À minha irmã Cleire e meu sobrinho Denny, pelo apoio à pesquisa nos Estados Unidos, em especial à minha sobrinha Rita pela disponibilização e apresentações de professores ligados às áreas de meu interesse no campus de Ann Harbor da Universidade de Michigan. Á minha irmã Denise e minha mãe Stanislava pelo apoio à viagem.

Ao meu caríssimo e distinto amigo Enelruy Camacho Azambuja, que tornou possível a realização de minhas viagens de pesquisa ao exterior.

Ao apoio recebido do amigo Francisco Pelucio, Ilmo. presidente do Sindicato das Empresas de Transporte de Carga de São Paulo e Região (SETCESP).

Ao meu querido e saudoso mestre, Huberto Rohden, pela sapiência transmitida e o apoio inestimável à minha formação humana e acadêmica. 
Aos mestres incentivadores da Faculdade de Filosofia, Letras e Ciências Humanas (FFLCH) pelos conselhos transmitidos; e de modo especial, aos PROFESSORES da Faculdade de Direito (FD) da Universidade de São Paulo preceptores de minha estima e reconhecimento, propositalmente, com letras maiúsculas: Prof. Dr. Antonio Rodrigues de Freitas Jr. e Prof. Dr. Enoque Ribeiro dos Santos, responsáveis por ministrar a disciplina "Direito Coletivo do Trabalho" (DTB5730-3) no segundo semestre de 2006.

Aos amigos discentes da mesma turma: Carolina de Oliveira Lemos Santos, pelos gentis e-mails enviados; Fernando Corrêa Martins, pelo árduo trabalho de escaneamento; Jouberto de Quadros Pessoa Cavalcante, pelas oportunas observações; Lauro Campos, pelas observações, cópias e acaloradas discussões; Mauricio Rodrigo Tavarez Levy, Renato de Almeida Oliveira Muçouçah, Rosimeire Cássia de Souza Cerqueira, Verônica Cavalcante da Fonseca e Wilson Pirotta, pela amável atenção recebida na obtenção de cópias via e-mail e salutares observações e sugestões. Muito obrigado aos colegas, inesquecíveis companheiros de estudos.

A toda a equipe da Coordenadoria de Assistência Social (COSEAS) da USP, pelo amparo e pelos recursos disponibilizados à execução deste trabalho.

Aos companheiros e companheiras de jornada e luta na Associação dos PósGraduandos (APG) da Universidade de São Paulo, campus Cidade Universitária-Butantã, gestão 2001, 2002 e 2003 (Chapa Pós-Pública), com quem compartilhei idéias e ações políticas em prol dos direitos dos estudantes pós-graduandos: defesa da universidade pública, gratuita e de qualidade. Deixo registrado testemunho de amizade e dedicação a todos: Menezes, Irani, Adelina, Ania, Daniel, Vivian, Max, Márcia, Mário, Wagner, Gigi, Arlene, Marisa, Arthur, Wagner, César, Zé Paulo, Giselle, Telmo, Cecília, Gilberto e Heitor. Saudações acadêmicas e saudades das reuniões de trabalho compromissadas na defesa por nossos ideais. Aos meus companheiros da Associação dos Moradores PósGraduandos do Crusp (AMPG), gestão 2004, partícipes de intensas lutas pela defesa dos direitos dos pós-graduandos no convívio nosso do dia-a-dia, em especial a Evandro de Carvalho Lobão, pela eficiência e dedicação.

Ao Senhor Alejandro Manuel Buenrostro y Arellano, coordenador do movimento "Xojobil", que mui gentilmente apresentou-me ao Sr. José Andres Peraza Menéndez e sua esposa, Profa. Dra. Leonor Sangines de Peraza, pela gentileza e hospitalidade durante 
minha estada na cidade do México, facilitando-me o acesso à produção desta pesquisa, visto que moram na Vila Panamericana, próxima à Universidade Autônoma do México, "Departamento de Coyocon". Ao meu dileto amigo Raul Arrioja Juarez que me hospedou em sua residência e conduziu-me a diferentes locais onde a cultura tradicional do povo mexicano se manifesta.

Ao amigo lingüista e bibliotecário, Edison Luís dos Santos, pela preparação, revisão e edição do texto original.

Aos meus prezados amigos uspianos, Daniel Afonso da Silva, mestre em História Social e Júlio Couto Filho, mestre e doutor em Filosofia, pela revisão conceitual, contribuições e oportunas observações.

Por fim, agradeço a todos os colaboradores e demais incentivadores, impossíveis de serem aqui nomeados, mas que de alguma maneira deram prestimosa contribuição à realização deste trabalho de pesquisa. 


\section{RESUMO}

A presente pesquisa pretende ser útil nos esclarecimentos da maneira pela qual a experiência advinda do processo de industrialização na Inglaterra, e aperfeiçoada pelos estadunidenses, denominada contrato coletivo de trabalho, poderia servir de parâmetro para o Brasil e México, em termos da contribuição que este instrumento tem dado ao bem-estar social dos trabalhadores. As relações históricas de trabalho no contexto da economia política e na contemporaneidade destes relacionamentos com blocos econômicos diversos são analisadas, bem como as implicações para as relações de trabalho, em especial para os contratos coletivos. As análises feitas visam contribuir para uma melhor compreensão histórica do conflito do capital versus trabalho para elucidar a maneira pela qual seria conveniente atentar para uma melhor compreensão do equilíbrio necessário para valorizar estas relações. Propõe analisar a situação econômica básica versus o processo político e a dinâmica do relacionamento das classes sociais trabalhadoras tendo em vista a influência da doutrina monetarista-liberal de Milton Friedman, chamada de neoliberal, incluindo-se aspectos do peso secundário que a América Latina tem no cenário estratégico dos grandes países capitalistas, por isso as análises foram realizadas tendo em vista preliminarmente uma distinção metodológica fundamental entre direito objetivo e direito não objetivado para que se compreendesse sob a luz dessa distinção as influências recíprocas da economia e da política sobre o homem no horizonte das indefinições da práxis social.

Procurou-se, também, o espírito da investigação histórico-estrutural, imiscuir-se nas influências externas comuns, questionando as facetas do internacionalismo trabalhista e suas ramificações, e a maneira como se desenvolveram comparativamente.

Palavras-chave: sindicato; contrato coletivo do trabalho; economia política; direito trabalhista; trabalhismo internacional. 


\begin{abstract}
The present study should be of interest for the understanding how the experience of labor collective bargain contract, allowed by the industrialization process in England and improved by the North Americans, should be used as parameter for Brazil and Mexico, in terms of the contribution that this instrument has been giving to the workers' social welfare. It analyzes also the history of the political economy and its contemporariness and the relationships with several capitalist blocks and the implications for the collective bargain contracts. It seeks for a best understanding the conflicts between capital versus labor, trying to elucidate the way should be better to comprehend the necessity of equilibrium, to promote the best value to the workers. It analyzes moroever the basic economy status versus the political process and the dynamics of the relationship of the working classes, considering the influence of the monetarist-liberal doctrine of Milton Friedman, called as neoliberal, included aspects of the secondary influence that Latin America has in the great capitalists' strategic scenery. The analyses were done in terms of the fundamental methodological distinction between the objective law and nonobjective law as a way to comprehend, under the focus of this distinction, the reciprocal influences from economics and politics concerning the man in the indefinite horizon of social praxis.
\end{abstract}

The spirit of the historical-structural investigations also attempts for a critical look of the external influences, questioning about labor internationalism faces and their ramifications that has been developed comparatively.

Key words: Labor Union, Collective bargain contract, political economy, Labor Law, Labor Internationalism. 


\section{SUMÁRIO}

DEDICATÓRIA _ 02

AGRADECIMENTOS _ 03

RESUMO _ 06

ABSTRACT 207

I - INTRODUÇÃO _

1.1. Metodologia __ 14

1.2. Problemas metodológicos das comparações estatísticas internacionais _ـ

II - SINDICALISMO NA ÉPOCA CONTEMPORÂNEA ___ 24

2.1. Estados Unidos _ 28

2.2. México _ 42

2.3. Brasil _ 58

III - EXPERIÊNCIA SINDICALISTA NOS ESTADOS UNIDOS __ 70

3.1. Federação Americana do Trabalho (AFL) _ 79

3.2. A lei trabalhista e os sindicatos __ 87

3.3. Classificação dos sindicatos nos EUA ___ 96

3.4. Descrição da organização sindical ___ 103

3.5. A formação de sindicatos trabalhistas (Modus operandi)___ 108

3.6. Alguns aspectos do cotidiano dos sindicatos ___ 114

3.7. O crime organizado e suas relações com as empresas e os trabalhadores organizados em sindicatos __ 123

IV - EXPERIÊNCIA SINDICALISTA NO MÉXICO ___ 131

4.1. O México pós-revolucionário ___ 134

4.2. Classificação dos sindicatos no México _ـ_ 140

V - EXPERIÊNCIA SINDICALISTA NO BRASIL___ 142

5.1. Experiência sindical no Brasil pré-1964__ 142

5.1.1. Classificação dos sindicatos no Brasil ___ 144

5.1.2. Descrição dos alicerces do sistema nacional de relações do trabalho ___ 150

5.1.3. A peculiaridade do sindicalismo brasileiro ___ 152

5.2. Sindicalismo brasileiro no regime de exceção (1964-1985)___ 156

5.2.1. A tácita persuasividade estratégica ___ 166

5.2.2. Balanço e retrospectiva histórica ___ 181

5.3. Experiência sindical na "Nova República” (1985-2005)___ 187

CONCLUSÃO _ 197

BIBLIOGRAFIA _ 224

ANEXOS 230

APÊNDICE _ 232 


\section{Ca pít u lo I}

\section{INTRODUÇÃO}

"Screib dich nicht zwischen die Welte, komm auf gegen der Bedeutungen Vielfalt vetrau der Tränenspur und lerne leben".

(Paulo Celan)

Com base no modo pelo qual se estruturaram as experiências do Contrato Coletivo de Trabalho (CCT) nos Estados Unidos, México e Brasil, em determinado ciclo histórico, examinaram-se os termos em que este instrumento tem (ou não) contribuído para ampliar o bem-estar social aos trabalhadores. De outro modo, investigou-se em que medida a consolidação dos Contratos Coletivos de Trabalho poderiam servir de parâmetro às regulações do mercado de trabalho e relações de trabalho no Brasil. E, na medida do possível, agregar novos saberes à diversificação da produção científica brasileira, por meio do diálogo com os demais setores de produção do conhecimento e co-participação com outras esferas de poder.

Do ponto de vista metodológico, e sem maiores pretensões, buscou-se torná-lo um instrumento acessível à compreensão dos interessados em aprofundar sobre a questão. Nesse sentido, a orientação desse estudo pautou-se em uma investigação históricoestrutural e conjuntural que procurou imiscuir-se das influências externas comuns, com ênfase de análise na maneira pela qual se desenvolveram comparativamente.

O Contrato Coletivo do Trabalho (CCT) mantém relação direta com o contexto histórico e a situação econômica, política e cultural dos países em questão; e suas funções têm se desenvolvido a partir da interação dinâmica desse contexto no ambiente das relações laborais. A maneira pela qual se estruturam grandes acordos capitalistas intermediados por blocos econômicos - Nafta (México, Estados Unidos e Canadá), Mercosul (Brasil, Paraguai, Uruguai e Argentina etc.) — influenciaram as relações

\footnotetext{
1 "Não escrevas entre palavras, / sobreponhas um olhar diante dos significados múltiplos, / confias no rastro das lágrimas e aprendas a viver". (Tradução do Autor)
} 
trabalhistas dos países-membros, introduzindo modificações na constituição dos acordos trabalhistas, em especial, nos Contratos Coletivos de Trabalho.

Quais são as perspectivas em médio e longo prazo destes acordos? E quais são os benefícios para os trabalhadores no âmbito do mundo globalizado? Que contribuição tais acordos trouxeram para a compreensão do conflito histórico entre os trabalhadores e empregadores? Ao debruçarmo-nos sobre a questão, haveria um modo mais conveniente de nos atermos à valorização desta interação? Com o intuito de esclarecer as indagações aqui perfiladas, empenhamos nosso esforço em descrever comparativamente as experiências de sistemas distintos de relações de trabalho, buscando contextualizá-las em relação aos sistemas político e econômico vigentes.

Cumpre ressaltar que, além da importância que o trabalho representa para o entendimento das novas relações sociais do mundo globalizado, a abordagem sobre o tema proposto oferece uma oportunidade de observação desses fenômenos em fluxo, e de modo abrangente, por isso procuramos sempre que possível compreendê-los à luz de uma inter-relação que se faz permanentemente, dinâmica, paradoxal e prospectiva.

A fim de propiciar estudo mais detalhado e didaticamente satisfatório, procuramos sistematizá-lo, conforme tipologia a seguir, principalmente com base nos aspectos dos sindicatos de trabalhadores, em relação a:

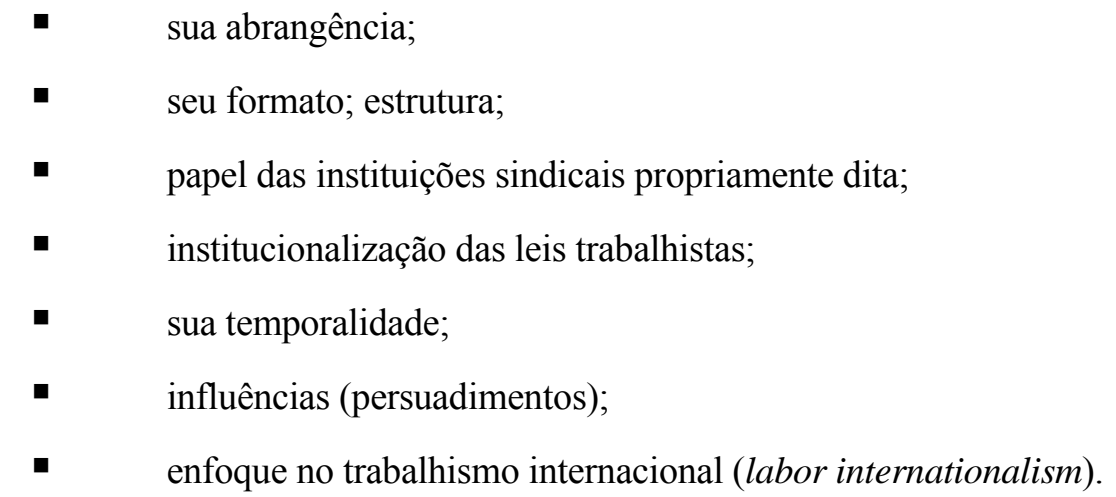

As relações de interlocução empresariais comumente mantidas com sindicatos, em particular, os de trabalhadores, têm sido objeto de grandes transformações consubstanciadas por diferentes influências de ordem político-econômicas, concomitantes à adoção de políticas econômicas neoliberais e, de igual modo, ao fortalecimento institucional das grandes corporações afinadas com premissas difundidas respectivamente 
pela segunda escola econômica de Chicago e pela Universidade de Harvard, as quais, por sua vez, foram endossadas pelo Consenso de Washington ou "Consenso Privado", uma das maiores expressões do neoliberalismo, no início dos anos 90.

Ao longo de diversos processos produtivos e formações socioculturais, não são raras as culturas e instituições que se têm posposto ao avanço das classes trabalhadoras não só para freá-la, mas para manter, a qualquer custo, o seu império político-econômico, a despeito da consciência de homens e mulheres, base de opressão milenar sob a qual a classe trabalhadora vem sendo, ao longo dos anos, relegada à berlinda da história. Esse mesmo espírito histórico do processo do desenvolvimento econômico-social aqui se apresenta de modo apriorístico, no sentido de revalorização do ser humano e recuperação da dignidade dos trabalhadores, como seres conscientes e não meramente acessórios, eventuais, tal como a história econômica os tem demonstrado.

Nessa perspectiva humanístico-científica, as universidades, especialmente as públicas, têm um importante papel a desempenhar na promoção do bem-estar do ser humano e na defesa da inaliabilidade dos valores éticos que refletem a dignidade de cada cidadão, para que sejam capazes de orientar a consecução de seu insofismável desígnio, em benefício próprio e da sociedade.

A racionalidade humana tem sido refém de armadilhas, busca-se quase sempre cooptá-la, e de modo mais intenso, afiná-la com os interesses do capital em detrimento do bem-estar social da classe trabalhadora, esta mesma racionalidade que destrói o próprio habitat, evidencia que o caminho a ser percorrido necessita ainda de muita reflexão, para clarear o obscurantismo da mente humana que, inadvertidamente, não se cansa de iludirse, vítima de sua própria insensatez.

O Contrato Coletivo de Trabalho é abrangente no sentido que procura incorporar valores econômicos, valores sociais e exercer determinada influência sobre os valores políticos quanto aos quesitos acordados num processo de interação crescente.

Num mundo cada vez mais contendente, explicações mais dinâmicas competem entre si, assim como as possibilidades de observações diretas que as sustentam. Tendo compartilhado das graduações em Ciências Econômica e Contábil em minha formação acadêmica, neste trabalho de pós-graduação em História Econômica, optei por empregar

\footnotetext{
2 DREIFUSS, René. A internacional capitalista: estratégias e táticas do empresário transnacional 19181986. $2^{\mathrm{a}}$ edição. Rio de Janeiro: Espaço e Tempo, 1987, p. 98.
} 
as metodologias das ciências sociais e suas diversas formas de acercar-se da realidade, porém, adotando mais a perspectiva histórica do que a teoria econômica, na tentativa de melhor compreender a verdade do sujeito interdependente do objeto. Sem entrar no mérito das contradições filosóficas de sujeito e objeto na teoria do conhecimento, mas de considerar o objeto como predicativo do sujeito capaz de realizar de maneira retroativa o revigoramento da interpretação que o sujeito dá ao objeto na dimensão dialética. A teoria em si não é absoluta na construção histórica, mas é fundamental para a interpretação coerente dos acontecimentos de modo a evitar contra-sensos.

Procurei explorar a alternativa do olhar interdisciplinar cujo propósito julguei condição necessária para uma visão abrangente de todos os atores envolvidos na consecução de seus objetivos, pois o caráter sinergético da interdisciplinaridade tem sido vital nas descobertas fundamentais interativas do ser humano em consonância com a complexidade e instabilidade dos sistemas em constante transformação.

Procurei destacar a questão dos juízos de valor, dependentes ou independentes de nossa vontade, implícitos ou explícitos na sua natureza, tendo seu uso deliberado somente no sentido de relevar o ser humano deste contexto contemporâneo de disformidade que a luta desigual provoca para a grande maioria e o leva a lutar por um padrão mínimo de sobrevivência, e com o intuito de diminuir, ao máximo possível, a sua ação deformante na investigação científica.

As mudanças na economia têm os seus reflexos observáveis nos acontecimentos políticos, sociais e, de uma maneira mais geral, culturais que acabam por consubstanciar os fatos históricos. Contudo, o que se convencionou chamar de "superestrutura", por uma questão de honestidade científica, não pode ser vista como sendo determinada estritamente pela "infra-estrutura", a despeito de o paralelismo existente de ambas ser altamente elucidativo para a compreensão desses mesmos fatos históricos.

A história não acabou nem nunca poderia terminar, o que tem que acabar é a análise linear da história e reafirmá-la como disciplina interativa dos verdadeiros valores da sociedade humana. Urge reinterpretá-la sob um enfoque não-linear que caracteriza a interdisciplinaridade. Os fatos quando analisados, linearmente, têm sido direcionados na ênfase sobre aspectos inerentes ao determinismo histórico; a aceleração do ritmo da evolução humana como seqüela da metamorfose acelerada do mundo material, ditada pelo desenvolvimento tecnológico, por vezes, de caráter inconseqüente. Esta perda 
momentânea do controle na capacidade de diferenciar o essencial do acidental é o aspecto negativo daquela análise linear, muito apropriada quando aplicada à ciência exata, mas inadequada à ciência humanista que a difere essencialmente pelo livre arbítrio, inerente ao espírito do sujeito humano e pela "creatividade"3 com poderes de mudar e romper as perspectivas sombrias que a análise linear tem retratado na construção histórica. Tal análise linear tem sido aduzida por uma pequena parcela da sociedade que não abre mão de seus privilégios exclusivos, pois ao analisar a essência menospreza a precedência de nossa existência cuja liberdade deveria prevalecer sobre nossas carências materiais e espirituais. Isto poderia invocar a construção de um modelo político que explicite o fundamento para o verdadeiro crescimento humano, obscurecido por uma interpretação rudimentar e secularizada por um condicionamento implícito. Ninguém se torna explicitamente aquilo que não é implicitamente. ${ }^{4}$ Na perspectiva linear do fim da história, o próprio direito acabaria não tendo sentido, pois a lei que tem sido um instrumento intransigente na defesa dos valores humanos, estaria sujeita a não se efetivar, por uma questão de temporalidade, pois a evolução material é tão rápida e constante que invalidaria sua eficácia em detrimento dos reais valores humanos. São os valores de mercado e a subserviência política que hoje se imiscuem de maneira inconseqüente em detrimento daqueles valores tão bem resguardados pelo verdadeiro direito. O que deveria ter um fim é a fantasia, que sempre muda, pois que continuamos a mesma coisa. A história não teria mais sentido, pois seria apenas uma curiosidade, somente quando o homem atingir sua plenitude.

\footnotetext{
${ }^{3}$ Como se referia meu saudoso mestre Huberto Rodhen: a palavra latina "creatividade" é a manifestação da Essência em forma de existência e o neologismo moderno "criatividade" é a transição de uma existência para outra existência. Como ele grafou, preferimos a verdade e clareza de pensamento a quaisquer convenções acadêmicas. O insofismável poder "creador" do universo e o "criador" de gado!

${ }^{4}$ Huberto Rodhen.
} 


\subsection{Metodologia}

A metodologia aqui adotada buscou combinar a necessidade de potencializar a perspectiva histórica comparativa com o procedimento dialético de análise, no sentido de investigar e interpretar, dinamicamente, os fatos histórico-econômicos que envolvem a constituição dos Contratos Coletivos de Trabalho em três diferentes países: EUA, México e Brasil. O estudo comparativo se debruçou sobre temas que propiciassem reflexão histórica em torno dos aspectos que o constituíram, segundo pressupostos teóricos de autores reconhecidos perante as ciências humanas e alinhados ao objetivo clássico da história: apreensão das experiências humanas para não incorrer em erro subentendido e sugerir alternativas através da síntese dialética, ou seja, um olhar atento ao historicismo relativista do neokantiano Wilhelm Dilthey, ${ }^{5}$ que pretende ter a consciência referente do passado como forma de poder compreender o presente e, assim, ter condições de vislumbrar um possível futuro mais promissor, mas não dentro de uma perspectiva linear de causa e efeito, mas numa perspectiva não-linear onde a compreensão é considerada a ferramenta capaz de atingir a realidade humana nas suas dimensões interativas fundamentais. Em se desembaraçando do passado, a história crítica proporciona-nos a construção da história científica, tornando inteligível o presente e nos prevenindo no tempo que se segue ao presente.

O tipo de pesquisa é a exploratória que objetiva tornar mais explícitas as idéias sobre o objeto do estudo. Recorremos à combinação de pesquisas bibliográficas aliadas à busca de informações na rede mundial interligada de computadores Internet, com participação em grupos temáticos <h-labor@h-net.msu.edu>, membro do Institute for Labor Studies \& Research $<$ http://www.rilaborinstitute.org $>$ e The Council for Research in Values and Philosophy (RVP), revistas especializadas, jornais, coleta de dados e entrevistas. Empregou-se a metodologia da história oral no México, Brasil e Estados Unidos da América, entrevistando pessoas especializadas no assunto, além de meu testemunho experimental "de visu" na área, que assim somados formaram o arcabouço do presente trabalho.

\footnotetext{
${ }^{5}$ Filósofo germânico (1833-1911) que empregou nova técnica de interpretação histórica ao abordar aspectos diferentes das experimentações psicológicas e empíricas próprias daquela época, abordado na sua obra póstuma Weltanschauung und Analyse des Menschen seit Renaissance und Reformation (1913) [Filosofia e análise do homem desde a Renascença até a Reforma].
} 
Um dos fatores inerentes ao processo histórico é a subjetividade cognitiva dos fatos sociais da qual a peculiaridade da história oral, como metodologia de trabalho, beneficia-se de ferramentas teóricas de diferentes disciplinas das ciências humanas. Tais fatos sociais, imbuídos de experimentos vivenciados pelos atores em sua íntima individualidade, têm o propósito de dar uma contribuição à história das relações de trabalho na reflexão dos personagens representados por cada um dos atores na formulação do conhecimento histórico quando relatam situações de aprendizado e decisões estratégicas.

Ao estudar a constituição de memórias, com o uso da história oral e fontes críticas, adotei postura de prevenção a fim de evitar a construção de memórias, além de empregar olhar atento quanto à distinção de memória permitida ou dominada como estratégias que buscaram reconhecer a realidade histórica, tão presente e tão distante. Tem o propósito de exprimir as situações-limite bem como a área máxima de que a história oral pode nos conduzir na investigação dos eventos histórico-trabalhistas com o uso da metodologia da Associação Brasileira de História Oral (ABHO).

No intuito de evitar o uso subjetivo de ideologias indevidas, preconceitos tendenciosos e o desvanecimento de memórias próprio da história oral, precavi-me no sentido de preparar-me com relatos mais contemporâneos sobre o assunto, indagando sobre estes relatos nos colóquios como forma de dar estrutura à entrevista, visto que tais relatos poderiam evidenciar prova ou testemunho de aptidão no assunto relatado. A fita cassete, com duas horas de duração, da entrevista com a diretoria do Centro de Apoio aos Trabalhadores (CAT) da cidade de Puebla de los Angeles, México, realizada no mês de setembro de 2004, encontra-se à disposição de interessados.

Consultando a Internet, tomei a devida precaução, dado o crescimento geométrico de informações disponíveis em quase quatro bilhões e meio de páginas (incluso cachê, dados de 2005), no sentido de observar atentamente as desvantagens embutidas no sistema, principalmente no que tange a aspectos como efemeridade das informações, inconsistência dos dados, controle bibliográfico obscuro e instantaneidade informativa, ou seja, mantendo permanente olhar crítico diante do binômio "tecnologia eletrônica versus produção acadêmica". É mister pesquisá-los para determinar se se harmonizam com os fatos conhecidos, e não moldá-los para que se ajustem, de modo apriorístico, a algum esquema teórico; numa alusão sobre o livre arbítrio de que a pessoa 
humana tem e na assunção de que os fatos históricos dependem mais da nossa liberdade do que de nossos ideais e carências materiais.

As causas e os efeitos das relações sociais entre seres humanos dificilmente podem ser entendidos somente por via do relato ipso facto, como conseqüência automática das circunstâncias; cumpre determinar em que grau a explicação relaciona o fato concreto com as disciplinas com as quais mantêm articulações, semelhanças ou vinculações sistemáticas. No estudo histórico das relações do trabalho e o capital, a presença do diálogo interdisciplinar permite apreender o modo como tais relações se emulam em contradições no Contrato Coletivo de Trabalho.

A observação social sem uma profunda reflexão e análise interdisciplinar não informa nem explica, consentaneamente, quaisquer que sejam as disciplinas. A complexidade, a falta de fundamentos e as variantes dos múltiplos fenômenos políticoseconômicos requerem que a investigação histórica seja complementada por muitas análises e que a investigação não deva ser somente estatística, mas de observações diretas e o uso de fontes originais. O uso de técnicas cliométricas pretende ter como resultado a reinterpretação do conteúdo real das informações no aprofundamento dos estudos históricos sobre a América Latina, bem como as considerações de políticas externas governamentais divulgadas, em parte, pelos meios midiáticos subjugados com o intuito persuasivo ideológico de inculcar aqueles valores. A produção científica tem demonstrado a capacidade do homem de conhecer e transformar seu meio, mas seu uso tem se mostrado insuficiente para atender as demandas sociais.

Uso pragmático do famoso provérbio Chinês: "Nada melhor que dar uma olhada in loco com os próprios olhos", de maneira despretensiosa com o intuito de procurar ter uma visão não distorcida da realidade.

Dentre os métodos estatísticos, preferi o de comparação binária. Este método pressupõe que a verdadeira relação entre os padrões de vida dos dois países fique entre os valores das duas relações obtidas inicialmente por uma avaliação dos PNBs (Produto Nacional Bruto) dos dois países aos preços de um país e depois aos preços do outro, e pressupõe que esse valor se aproxime da média geométrica destas duas relações.

O PNB (Produto Nacional Bruto) melhor do que o PIB (Produto Interno Bruto) reflete a vulnerabilidade dos países dependentes de capital externo, nesta fase neoliberal do capitalismo em que se privilegia o financeiro em detrimento do econômico, pois o 
PNB incorpora a RLFE (Renda Líquida de Fatores Externos) que, no Brasil (2004), tem sido negativa, pois se envia muito mais para o exterior a título de lucros que não são reinvestidos aqui, ou seja, com uma delicada situação de política econômica assaz atrelada à dependência de capital, das privatizações que apesar de terem aumentado nosso ativo líquido, em longo prazo, em nada favorecem a economia nacional e dos juros bancários diversos. Isto tudo, tendo em mente a crescente exportação e o mercado de câmbio, inclusive o negro, que garantem os recursos reais que são enviados ao exterior, comprometendo assim o desenvolvimento econômico com crescimento sustentável como condição indispensável para a respectiva criação de empregos e o progresso de suas relações desde que formam o elo complementar ao progresso econômico com desenvolvimento social.

Entretanto, a interpretação da matriz do PNB habitualmente usada pelos governos não foca o trabalho doméstico, serviços na economia informal, potencialidades latentes na educação e a qualidade das pesquisas, custos da poluição do ar, água e da destruição das florestas. No Brasil, segundo IBGE (2005), dos aproximadamente, 80 milhões de trabalhadores, apenas 32 milhões estão protegidos pela lei e 48 milhões (34\% são jovens) não têm proteção alguma, ou seja, uma vez e meia do total dos protegidos estão na informalidade.

Outro fator a considerar refere-se ao conceito de serviço e produto que do ponto de vista da produção final de uma mercadoria na empresa, quando terceirizada na intermediação daquele produto, é contabilizada como serviço. O conceito de serviço, de grande heterogeneidade, faz das comparações quantitativas internacionais uma tarefa relativamente difícil de acordo com projeto International Comparison Project da ONU, que vem investigando outros métodos de interpretação mais adequados, pois as comparações internacionais têm componentes essencialmente relativos e arbitrários tornando os cotejamentos entre países bastante duvidosos, e pouco convincentes.

O crescimento da demanda por serviços no mundo globalizado cresce em importância na determinação do desempenho econômico das nações, pois a razão para o crescimento da oferta de tais serviços está na sua própria demanda fortemente elástica medida pela respectiva proporção da força de trabalho e o resultado da combinação daqueles fatores na produção de serviços. 
A empresa privada muito mais capacitada e eficiente de seu desígnio capitalista neoliberal leva nítida vantagem ao segregar seu desempenho real, dificultando uma análise que pudesse nos dar uma dimensão mais adequada da sua contribuição econômico-social.

Quando por falta de dados consistentes ou quaisquer aspectos de percepção que não pudessem ser, adequadamente, mensurados, pesquisei baseado em observações históricas e empíricas, essas junto aos atores no cenário cotidiano e procurando realçar o ethos nas suas acepções semânticas de: costume, moral, ética e proceder.

Outros estudos estatísticos, elaborados com base na metodologia do professor Hossein Arsham, disponível em http://home.ubalt.edu/ntsbarsh/index.html, foram utilizados numa tentativa de oferecer melhor entendimento da matéria exposta. Qual o resultado de tal processo contratual coletivo, de origem anglo-saxônica, aplicado a países latino-americanos onde estão implícitos os fatores culturais e dinâmicos de suas economias?

Um dos propósitos deste trabalho, após a devida apreciação da distinta mesa, é torná-lo mais acessível aos trabalhadores (as), se possível, adaptando-o à linguagem mais didática e coloquial, com base em explicações extraídas da experiência, conquanto mantido o rigor científico, como forma de retribuição àqueles que financiam a universidade pública, e o compromisso moral de levar conhecimento a quem o tem por direito e dele mais o necessitam. 


\subsection{Problemas metodológicos das comparações estatísticas internacionais}

Dados estatísticos agregados não permitem uma visão real dos aspectos microeconômicos de uma economia. Nos estudos das relações do capital e o trabalho é comum defrontarmo-nos com índices estatísticos diversos, mas o que nos interessa aqui é o índice de produtividade do trabalho. Nem sempre estão disponíveis, estudos pormenorizados de tais índices, o que pode levar à ausência de precisão e/ou interpretações indevidas.

Destacamos a relevância do estudo realizado pelo Departamento de Comércio Norte-Americano por intermédio do "Center of Economic Studies of U. S. Census Bureau" que exemplifica bem o fato. Houve um aumento de $2.4 \%$ na produtividade do trabalho na Indústria de Reposição de Auto Peças de 1987 a 1992. Examinemos o gráfico a seguir:

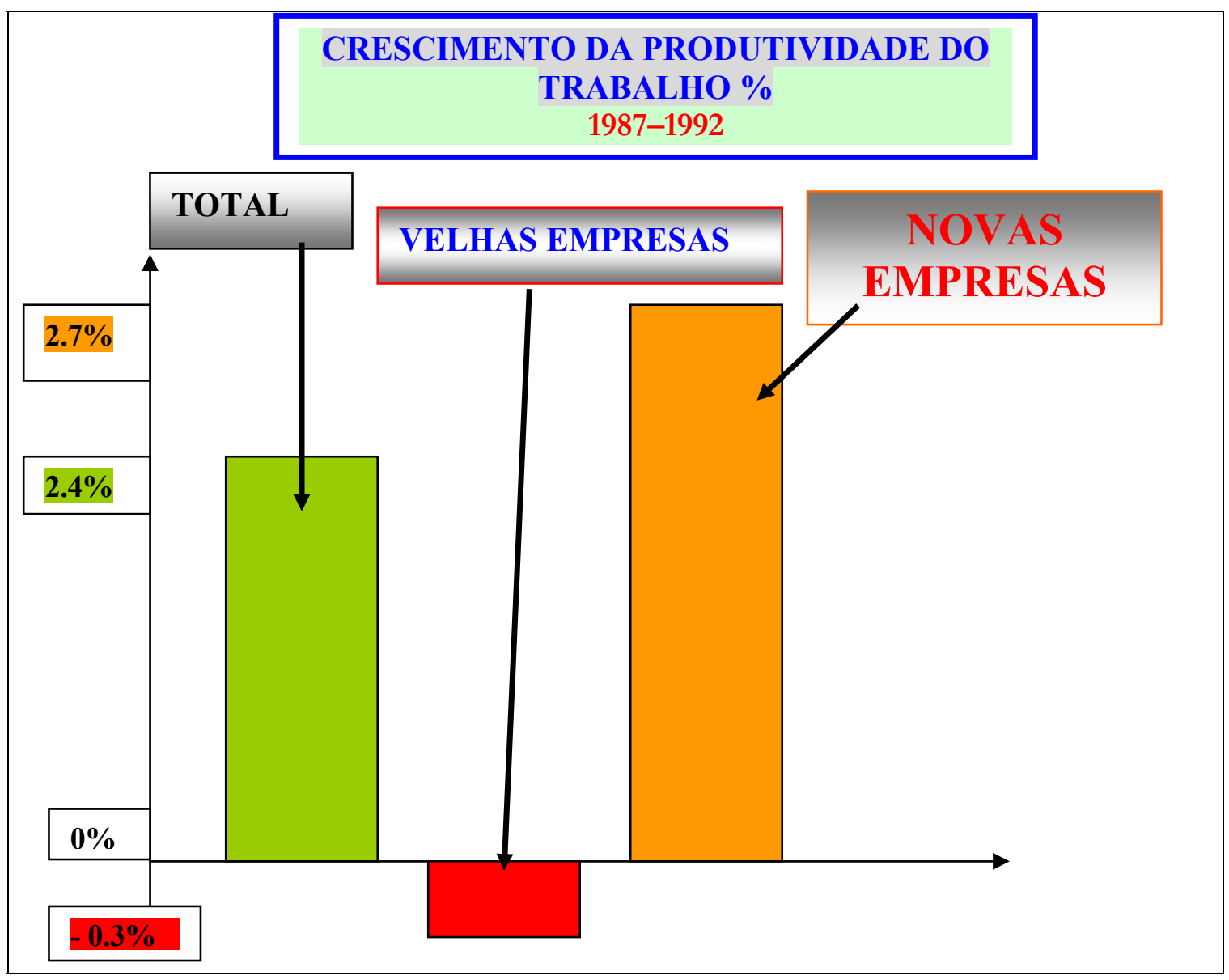

Fonte: Departamento do Comércio USA - Bureau of Census. 
Os novos negócios do setor foram responsáveis por um aumento de $2.7 \%$ na produtividade do trabalho, conquanto as velhas empresas reduziram a produtividade do trabalho em $-0.3 \%$, resultando um aumento líquido de $2.4 \%$.

Vejamos o que apontam os indicadores de aumento líquido dos empregos numa relação direta com a produtividade no mesmo setor e período:

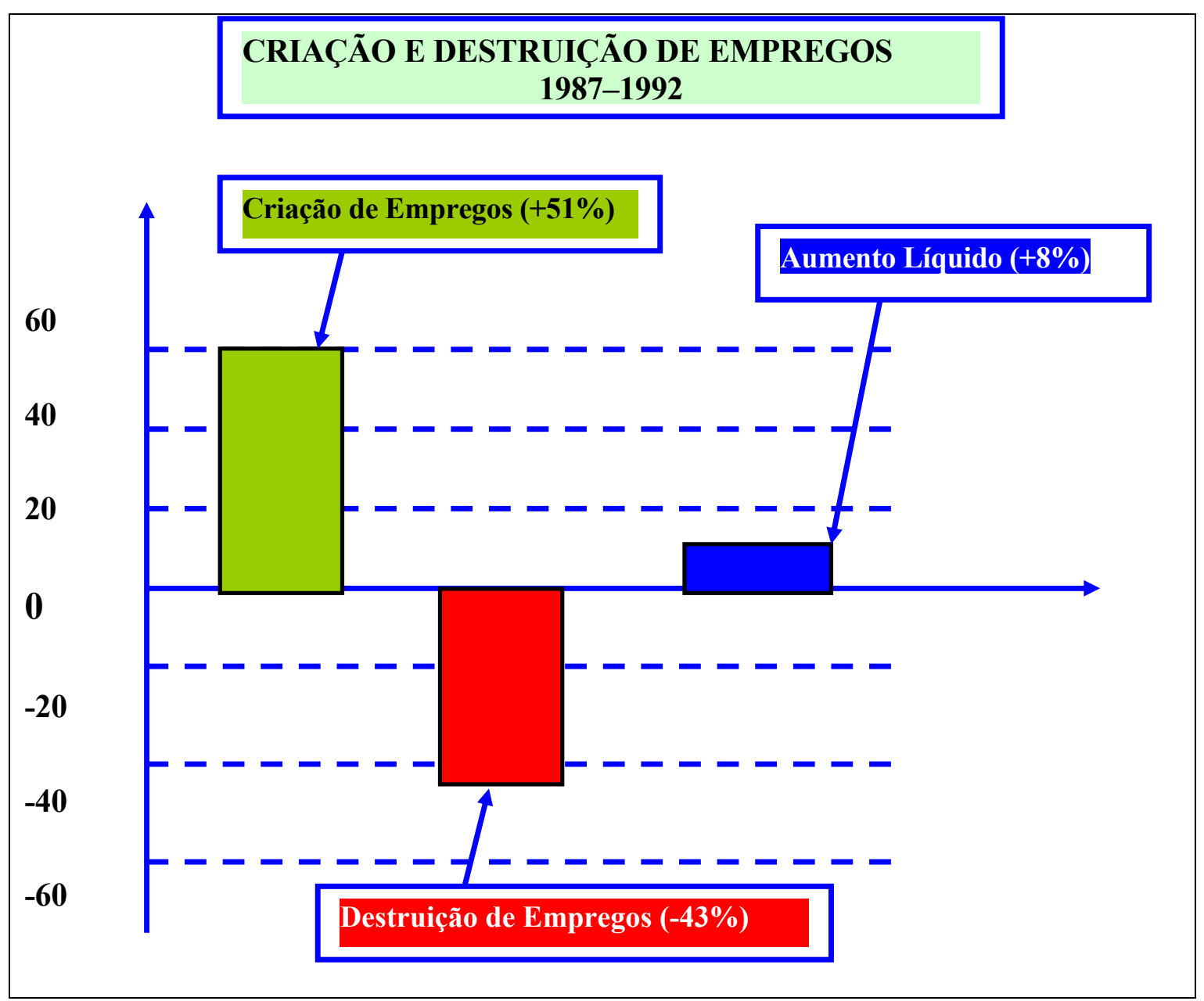

Fonte: Departamento do Comércio USA - Bureau of Census.

De acordo com ambos tipos de empresas, as novas e velhas apresentaram um aumento bruto na taxa de emprego de $\mathbf{5 1 \%}$ o que significa que mais da metade dos empregos em 1992 não existiam em 1987. As velhas empresas tiveram uma destruição de emprego bruto de $\mathbf{- 4 3 \%}$ o que significa que mais de 4 em 10 empregos que existiam em 1987 foram eliminados em 1992 e que resulta num crescimento líquido do emprego de 8\% (Bureau Census). As análises das magnitudes destas constantes mudanças são fundamentais para a compreensão da produtividade na atual conjuntura internacional de divisão do trabalho, pois as empresas despedem e contratam grupos de trabalhadores 
assim que se aventuram em novas empreitadas em diversas áreas com o uso de alta tecnologia. Despedem os empregados com velhas habilidades e contratam novos empregados com conhecimento de programação computacional, trabalho e experiência na rede internacional mundial interligada de computadores e outras especialidades da incrível velocidade do avanço tecnológico hodierno. Fato que, geralmente, no Brasil e México se dá com a demissão do trabalhador sem a contrapartida de uma nova contratação o que vem caracterizar seus altos índices de desemprego em suas respectivas economias mal estruturadas. Dentro da lógica neoliberal de uma industrialização secundária a destruição de empregos tende a ser maior do que sua criação.

Estas informações, detalhadas em nível microeconômico, são fundamentais para orientar políticas públicas e neste caso refletem bem as mudanças na bastante flexível economia de mercado norte-americana e a relação dos salários com respectiva produtividade de trabalho que os sindicatos têm de negociar nos Contratos Coletivos de Trabalho.

Outro aspecto na análise estatística, no Brasil e México, principalmente, é a "taxa de desemprego aberta" oficial que constitui um subconjunto da população economicamente ativa (PEA) que não tem emprego, mas desconsidera certos aspectos econômicos e sociais dos que estão empregados no que se refere à qualidade em termos de salários, temporalidade e o emprego disfarçado da economia informal. Seguindo os padrões estritos de cálculo do desemprego para países de industrialização secundária, apesar do constante aprimoramento, ainda carecem de método mais específico para auferir resultados que condigam mais apropriadamente com as realidades inerentes desses países.

Tal qual a História, a Estatística emprega habitualmente experiências passadas para interpretar possíveis acontecimentos no futuro. Adotei os seguintes símbolos na interpretação dos significados estatísticos:

- $\quad$ = Dados não existentes

- $\quad$ = Dados contraditórios

- $\quad ! \quad=$ Dados não confiáveis

- $\quad$ N\$ $=$ Dados sem significado econômico

- $\quad \& \quad=$ Dados tendenciosos

- $\%=$ Dados importantes para industrialização secundária 
Assim como as leis trabalhistas são diferentes em países diversos, também as funções dos sindicatos diferem-se de país para país, bem como suas relações políticopartidárias. No caso brasileiro, por exemplo, a unicidade sindical de base territorial é um sistema de representação obrigatória, recebendo as benesses acordadas em contratos coletivos, independentemente de sua filiação, apenas os agregados recebem serviços assistenciais e votam em eleições sindicais, pois estas particularidades podem tornar as comparações ambíguas. Estas relações são importantes para se ter uma compreensão dos conflitos que se verificam entre os interesses capitalistas e dos trabalhadores. No Brasil e México, o sistema de leis trabalhistas afeta o papel dos sindicatos desde que salários e benefícios são notoriamente determinados por ação governamental, ainda que, mais recentemente, com a diminuição da função do Estado na proteção do empregado dentro da ótica neoliberal, verifica-se uma precarização generalizada nas relações sociais, principalmente nas relações de trabalho.

Porém, nos EUA, os sindicatos barganham coletivamente seus salários + benefícios e as forças de mercado determinam as resoluções dos possíveis conflitos de interesses com pouca interferência de leis trabalhistas, exceto nas suas atribuições de um padrão mínimo aceitável destas relações, condizentes com o atual estádio de desenvolvimento capitalista mais liberal da sua extensa economia global.

As particularidades da origem do termo "Contrato Coletivo" nas diversas legislações nacionais, incluindo as próprias doutrinas, sem uma conotação jurídica mais lata, vinculam-se tão estreitamente, que se torna possível distinguir diferenças históricas fundamentais; remete-nos aos primórdios do direito civil, como ordenamento regulador de relações voluntárias, em que a legitimação desta relação fazia-se através de um contrato, que se denominava "coletivo" quando consagrado a uma agremiação de trabalhadores.

No direito de trabalho contemporâneo, o vocábulo "contrato" tem um significado característico, bem distinto daquele derivado do direito civil no qual a vontade das partes predominava, pois as relações entre empregado e empregador deveriam sujeitar-se às determinações protecionistas e vindicatórias de sua inserção dentro dos parâmetros do direito social e, essencialmente, do trabalho, como determinantes de suas ações. Em certos casos, a figura de um Contrato Coletivo do Trabalho (Collective Bargain Contract) estaria mais de acordo com o interesse profissional; o termo "contrato 
profissional de barganha" estaria mais bem conceituado e mais afinado com um pacto deliberado por meio do qual se busca regulamentar as condições coletivas de trabalho.

FLUXOGRAMA DA EVOLUÇÃO DO CONTRATO COLETIVO DE TRABALHO

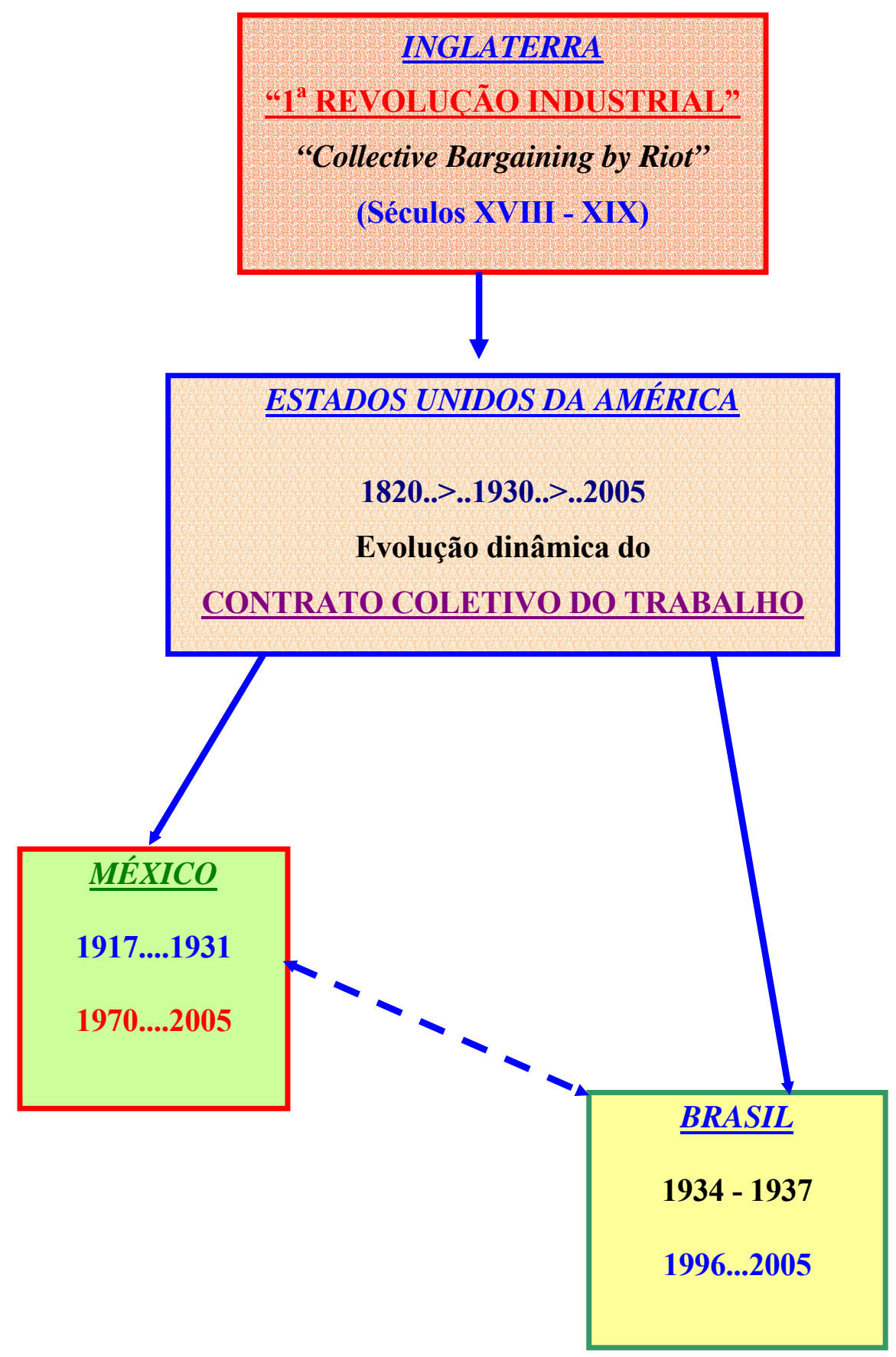




\section{Ca pít u lo I I}

\section{SINDICALISMO NA ÉPOCA CONTEMPORÂNEA}

Após a divulgação do relatório elaborado pela OIT (Organização Internacional do Trabalho) em 1997, tornou-se notável a unissonância de opiniões quanto ao declínio do movimento trabalhista sindical não só na América Latina, mas em diferentes partes de todo o mundo. As raras exceções se aplicam apenas a alguns países da Europa setentrional, onde a distribuição de renda é mais socialmente equilibrada como Suécia e Finlândia. Segundo estudo realizado em 1995, o economista Gerald Friedman constatou que a densidade de membros de sindicatos de trabalhadores tem caído firmemente em 12 de 16 países capitalistas. Beneficiando-se de emprego estável, e interessados em defender a continuidade de seus postos de trabalho, os trabalhadores se viram inseridos em formas de organização social e profissional que lhes tornam os sindicatos, em muitos casos, não somente dispensáveis, mas igualmente antipáticos.

Diversos estudos sobre a densidade sindical indicam tendência inexorável de encolhimento na maioria das economias desenvolvidas: no Canadá de 37\% em 1984 para 30\% em 2004; na Inglaterra de 44\% em 1969 para 30\% em 2000 (19\% no setor privado); na Austrália de 51\% em 1971 para 23\% em 2002; na Alemanha de 37\% em 1969 para 19\% em 2003; nos Estados Unidos de 35\% em 1943 para 13\% em 2002 (8,6\% no setor privado).

$\mathrm{Na}$ maioria dos países industrialmente desenvolvidos cerca de $40 \%$ da população economicamente ativa encontra-se subempregada no que se caracterizou chamar de emprego anômalo, parcial e temporário de curta duração, intermediado com taxas de desemprego crescente e remuneração decrescente. Nos países em vias de desenvolvimento esta taxa é ainda maior, no caso do Brasil são $60 \%$, pois dos aproximadamente 70 milhões de trabalhadores, de 10 trabalhadores, 6 estão no mercado informal e somente 4 encontram-se no mercado formal.

De acordo com estudo realizado por pesquisadores do Bureau of Labor Statistics (BLS) dos Estados Unidos da América, os Contratos Coletivos de Trabalho (CCTs) que 
contêm cláusulas de arbitragens com referência às queixas trabalhistas têm crescido regularmente. Assim, em 1944 era de 73\%, enquanto no começo dos anos 80, de 95\%, e em 2005 de 98,5\%, evidenciando o crescente descontentamento geral da classe trabalhadora norte-americana. $\mathrm{O}$ procedimento de arbitragem foi o método preferencialmente usado, de maneira mais categórica, nas disputas trabalhistas desde o início da industrialização quando as greves eram vistas de uma maneira muito arbitrária pelos respectivos governos.

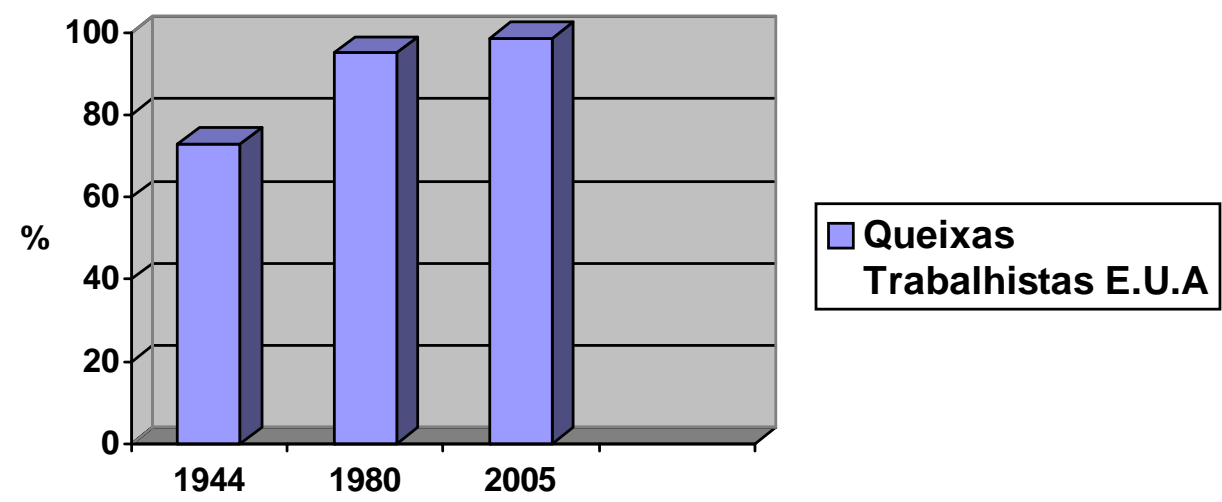

Fonte: Bureau of Labor Statistics (BLS).

Cada vez mais este instrumento na decisão de disputas trabalhistas tem sido preferido pelas partes sindicalizadas e, crescentemente, pelos setores não-sindicalizados como forma de desafogar os abarrotados tribunais de justiça. Nos EUA tornou-se popular durante a Segunda Guerra Mundial quando a interrupção grevista na produção de armamentos colocava em perigo a segurança nacional, por isso, acrescentaram a cláusula de arbitragem nos Contratos Coletivos de Trabalho nos quais aquela relação se verificava. Tornou-se efetiva como cláusula resolutiva de acontecimentos, dinâmicos por natureza, não previstos pelas partes ou se uma das partes não cumprisse cláusulas contratuais.

A vertente internacionalista dos sindicatos europeus tem se reunido no que denominaram Congresso do Sindicalismo Global (CONSIG) onde contestam os desafios das organizações trabalhistas no mundo sob a égide neoliberal.

Para se ter uma idéia, em Portugal, o contrato coletivo é uma reprodução deformada do que supostamente o deveria ser, com pouquíssimas alterações nos últimos anos: dos 415 contratos coletivos em vigor (2002), mais de $80 \%$ são cópias literais do que 
haviam sido há mais de 15 anos, salvo mudanças insignificantes nos quesitos salário, vale-refeição e outros benefícios que descaracterizam a esfera da negociação propriamente, resultando em situações que sugerem haver a concessão unilateral do empregador. Colin Crouch elabora uma nova tipologia para os sindicatos com características neocorporativistas; sua proposta de classificação se compõe basicamente de 2 (duas) variáveis principais:

1. o poder das representações sindicais;

2. o nível de articulação organizacional do capital e do trabalho, ou seja, a capacidade das organizações representativas de empregados e empregadores de agir estrategicamente, exercendo liderança sobre seus membros de forma a garantir os acordos firmados. ${ }^{6}$

Da junção de ambas as variáveis derivam 4 (quatro) modelos:

I. Países com negociação e contestação pluralistas e com baixo poder sindical, gerando um sistema de relações de trabalho estável;

II. Pluralistas, com sindicatos fortes e, portanto, com sistemas instáveis;

III. Neocorporativistas com sindicalismo forte; e

IV. Neocorporativos com sindicalismo fraco.

No último grupo estariam Suíça e Holanda e, em certa medida, a Alemanha. No grupo III, os países classicamente citados como neocorporativos: Suécia, Noruega e Áustria. No grupo dos pluralistas instáveis estariam Reino Unido, Finlândia e Itália; e no grupo I, tanto Portugal e Espanha, como diversas regiões dos Estados Unidos. Conforme aponta Noronha, "o modelo de Colin Crouch, apesar de instigante é, ao mesmo tempo, um tanto desconcertante por agrupar países em que a legislação do trabalho é bastante abrangente (Espanha) com países (ou regiões) onde ela é residual (EUA)". 7 Para efeito de comparação, achei pertinente registrar o modelo proposto por esses autores, a fim de

\footnotetext{
${ }^{6}$ CROUCH, Colin. Industrial Relations and European State Traditions. Oxford: Clarendon Press, 1994, p. 43.

${ }^{7}$ NORONHA, Eduardo Garuti. O modelo legislado de relações de trabalho no Brasil. In: Dados [online]. 2000, vol. 43, n. 2. Disponível em http://www.scielo.br/scielo.php?script=sci arttext\&pid=S0011$\underline{52582000000200002 \& \operatorname{lng}=\text { pt\&nrm }=\text { iso. }}$.
} 
ampliar o entendimento das experiências relativas aos sistemas de relações de trabalho nos casos brasileiro, mexicano e estadunidense.

Rigorosamente, enquanto tipos ideais distinguem-se apenas dois modelos puros:

1. modelos em que a lei predomina sobre os acordos coletivos e sobre o poder discricionário das empresas - é o caso do Brasil, México e da maioria dos países latino-americanos;

2. modelos em que predominam os acordos coletivos como marco normativo das relações de trabalho - o Reino Unido e EUA.

Muitos países podem ser considerados modelos híbridos, onde há relativo equilíbrio entre lei e acordos coletivos. Por fim, poder-se-ia supor a existência de países nos quais predomina o poder discricionário dos empresários, livre de pressões expressivas de sindicatos ou constrangimentos legais; neste caso dificilmente poderíamos fazer menção a modelos, mas tão-somente a um sistema primitivo ou inicial de relações de trabalho.

De um certo ponto de vista, conforme conclui Eduardo Garuti Noronha, poderse-ia dizer que no Brasil "o poder discricionário do empregador desafia a preponderância da lei, enquanto os contratos, se existentes, têm papel subordinado"; ${ }^{8}$ contudo, com o advento de uma nova perspectiva dos contratos coletivos que sobrepujam a lei, exceção feita aos direitos constitucionais, de acordo com a lei 5483/2001, evidencia que as coisas estão mudando, grosso modo, em consonância aos parâmetros políticos adotados pela perspectiva neoliberal em curso no país. De acordo com a visão de Colin Crouch, o Brasil parece estar atualmente inserido em um modelo híbrido. ${ }^{9}$

\footnotetext{
${ }^{8}$ NORONHA, Eduardo Garuti. Idem, ibidem.

${ }^{9}$ CROUCH, Colin. (1994) Op. cit., p. 12-20.
} 


\subsection{Sindicalismo nos Estados Unidos}

Pode-se dizer que os trabalhadores estadunidenses têm alcançado relativo êxito econômico, principalmente, por causa da consolidação e alavancagem de sua extensa economia que lhes têm permitido tal desempenho. Exxito relativo, pois nos últimos 20-25 anos, as enormes riquezas derivadas do trabalho ( $38 \%$ do total das riquezas $)^{10}$ foram aproveitadas por uma minoria, mas que retém domínio e grande influência político-social e corresponde a apenas $1 \%$ da população.

De acordo com as estatísticas do Bureau of Labor Statistics (BLS), de 1947 a 1972, a produtividade e o crescimento salarial real estiveram pari passu numa relação de equivalência ótima para o trabalhador. Apesar de ser consenso designar o ano de 1950, após o término da Segunda Guerra Mundial, o início da era pós-industrial, tal fato se dá com maior intensidade nos anos 1970 e tem evidenciado um aumento de contradições ainda não devidamente resolvidas. A produtividade em relação aos salários + benefícios entre 1973 e 1993 apresentou bom desempenho no sentido de uma distribuição daquela produtividade atrelada ao crescimento salarial, mas a partir de 2000 esta diferença vem crescendo sobremaneira em favor do lucro das corporações, mas em detrimento do crescimento salarial real. Os gráficos abaixo mostram como a produtividade cresce muito mais rapidamente do que os salários. Isto significa que os lucros líquidos das corporações cresceram muito mais em função, principalmente, desta relação decrescente dos salários reais.

Com isso enfraquecem o poder aquisitivo das famílias americanas, bem como tendem a conduzir a economia a uma recessão, uma vez que para as corporações continuarem com os altos lucros em cima da produtividade dos trabalhadores, como condição necessária na lógica capitalista neoliberal, deveriam, impreterivelmente, baixar o nível do salário real ainda mais. $\mathrm{O}$ estudo comparativo leva em consideração toda a evolução histórica de ambas as partes, salientando, entretanto, que não podemos incorrer num sofisma de composição social ao considerar os valores humanos como meta a ser alcançada tão somente após as prerrogativas do capital e nos abstermos da condução de nossos desígnios em prol de uma sociedade que seja sustentável, não só para uma minoria

\footnotetext{
${ }^{10}$ The Guardian, em 28 de Abril de 2002.
} 
privilegiada, mas, principalmente, para a grande maioria, miserável, sem o que não haverá equilíbrio de sustentação jamais. E os primeiros reflexos de tal insustentabilidade começam a preocupar a humanidade, ao que parece, atualmente mais ciente deste modelo de inexorabilidade que pode vir a caracterizar tal ato perverso.

$1^{\mathrm{O}}$ QUARTO DE $2000 \mathrm{AO} 1^{\mathrm{O}}$ QUARTO DE 2004.

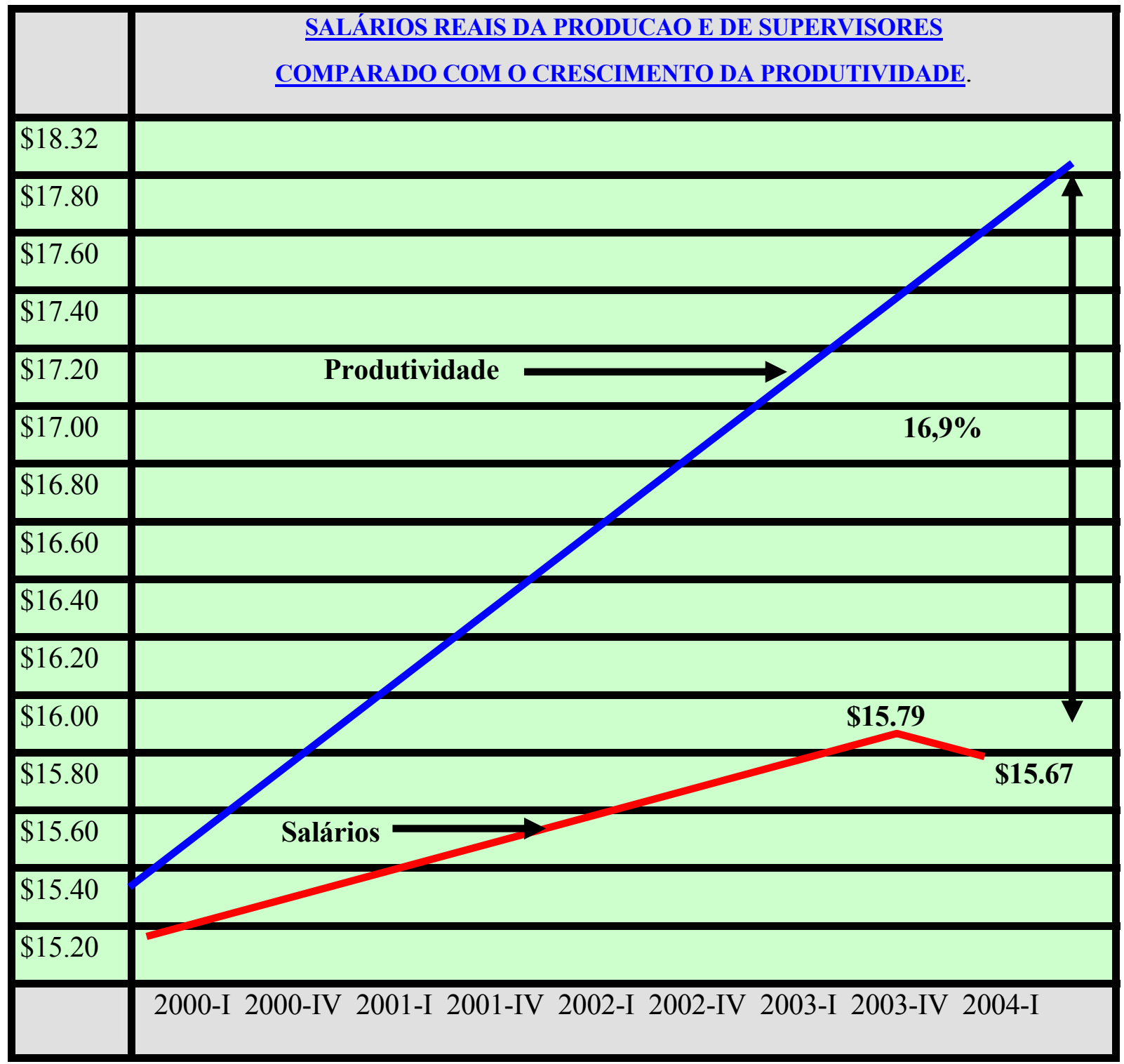

Fonte: Bureau of Labor Statistics (BLS), Current Employment Statistics.

O crescimento do déficit estadunidense retrata a dependência de capital virtual que correntemente a economia norte-americana tem em relação ao capital real que o está conduzindo a um labirinto sem saída quando esta relação com a situação de fato da sua extensa economia globalizada é falaz. Haja vista um só aspecto de tal assertiva no 
delineamento da atual crise imobiliária que demanda capital (virtual) em contrapartida ao bem econômico real (Real State)! Um ótimo indicador desta relação é a Bolsa de Valores, palco de dramas contundentes, pois mede a relação lucro/ações que historicamente esteve situada na proporção estável e real de 15/1, mas nos últimos 15 anos a proporção tornouse instável e irreal de 35/1. Em outras palavras, isto significa que os investidores julgam, segundo lucubração do Fundo Monetário Internacional, que seus lucros irão crescer de $6 \%$ a $8 \%$ ao ano, mas até quando os trabalhadores vão permitir tamanhos despojos.

Aparenta ser uma armadilha tal situação, podendo transformar-se numa crise de grandes proporções com a destruição de vários segmentos de mercado. ${ }^{11}$ Tem sido constante o aumento do endividamento das famílias norte-americanas, a julgar pela disponibilidade de renda que duplicou, elevando-se de 65\%, em 1985, para 132\% contemporaneamente.

Segundo a Organização Internacional do Trabalho, em outubro de 2001, o consumo estadunidense cresceu cerca de 7.3\% com a injeção de US\$ 307 bilhões na economia, mas proveniente da reinversão de seu próprio capital pró-consumo, via empréstimos bancários diversos, e não da contribuição da produtividade ao salário, mas sim, na manutenção dos preços com reduzida taxa de juros (Sub Prime). Atualmente, a economia norte-americana necessita cerca de US\$ 2 bilhões de ingresso-dia para continuar ativa e a mudança conjuntural global na disponibilidade de recursos sinaliza dificuldades crescentes, principalmente se os juros crescerem, para seu financiamento; o eixo Norte-Norte muda-se gradativamente para o eixo Sul-Norte, pois os fundos de mercados emergentes do sul são investidos maciçamente no Norte. Os cinqüenta vôos diretos em 2007 para os sete vôos de 2000, os 69 bilhões de dólares de 2006 para os 6 bilhões em 1995 demonstram o aumento vertiginoso do fluxo de comércio entre o Oriente Médio e a China ${ }^{12}$.

Mudou a fantasia em relação à explosão da crise de 1929, mas as condições são semelhantes e a ilusão do lucro fictício é contumaz, a crise contemporânea caracteriza-se

\footnotetext{
${ }^{11} \mathrm{O}$ autor desta tese em viagem aos EUA (junho a outubro de 2004) pode constatar que apesar dos salários não estarem crescendo como deveriam, o consumo vinha batendo recordes desde 2001 crescendo na base de até $7 \%$, sobretudo em função dos empréstimos bancários diversos, em particular nos "credit cards" em que os $60 \%$ da população mais pobre sobrecarregou-se com a elevação de suas dívidas em até três vezes mais.

12 Financial Times, December 10,2007.
} 
por ser mais homeopática e persistente e bem por isto nem sempre devidamente observada nas conseqüências de longo prazo.

\section{DÉFICIT ESTADUNIDENSE}

\section{PERCENTAGEM DO PRODUTO INTERNO BRUTO}

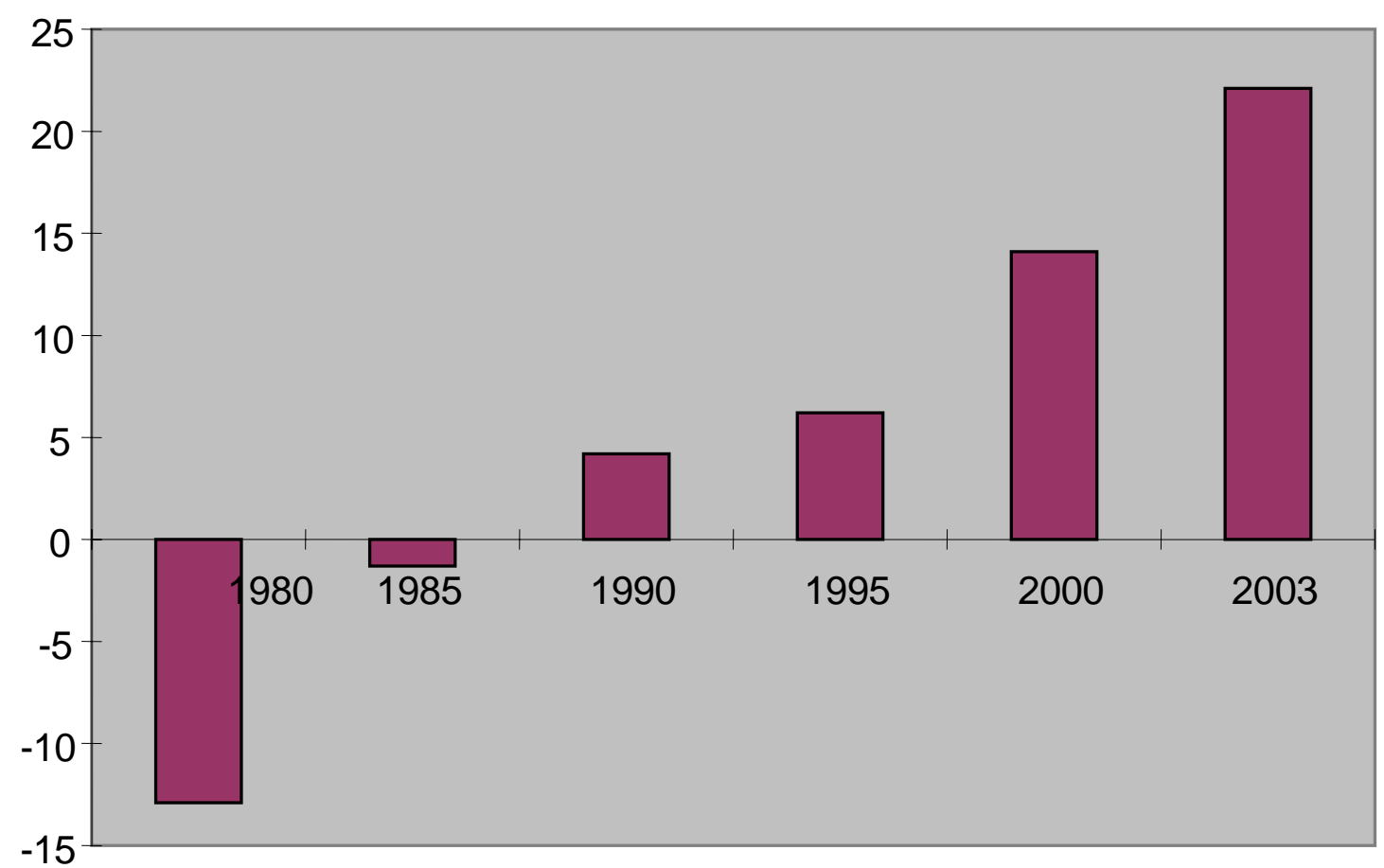

Fonte: BLS - Bureau of Labor Statistics, Department of Labor - Overall Most Requested BLS Statistics. Disponível em: http://data.bls.gov/cgi-bin/surveymost?bls. Statistical Overview of the U. S. Economy. March 2006. 


\begin{tabular}{|c|c|c|c|c|}
\hline & Período & $\begin{array}{l}\text { Benefícios } \\
\text { + Salários }\end{array}$ & $\begin{array}{c}\text { Lucros } \\
\text { Corporações }\end{array}$ & $\begin{array}{c}\text { Lucros } \\
\text { Corporações/Salários }\end{array}$ \\
\hline 1950 Q I - & - 1951 Q IV & 61.0 & 17.9 & 0.29 \\
\hline 1954 Q III - & - 1956 Q II & 63.5 & 17.8 & 0.28 \\
\hline 1958 Q III - & - 1960 Q II & 64.4 & 17.4 & 0.27 \\
\hline 1961 Q II - & - 1963 Q I & 58.0 & 19.0 & 0.33 \\
\hline 1971 Q I - & - 1972 Q IV & 59.8 & 13.7 & 0.23 \\
\hline 1975 Q II & - 1977 Q I & 66.5 & 15.4 & 0.23 \\
\hline 1983 Q I - & - 1984 Q IV & 54.5 & 14.5 & 0.27 \\
\hline 1991 Q II & - 1993 Q I & 67.3 & 12.0 & 0.18 \\
\hline 2002 Q I - & - 2003 Q IV & 38.6 & 40.5 & 1.05 \\
\hline
\end{tabular}

Fonte: US Bureau of Economics Analysis, National Income and Products Accounts Tables, 19612003; prepared by Andrew Sum, Paul Harrington, Paulo Tobar and Ishwar Khatiwada. Center for Labor Market Studies, North-eastern University. Boston, Massachusetts, March 2004. Disponível em: www.bea.gov; adaptada e complementada com outros cálculos.

As oscilações dos lucros das corporações em relação aos salários + benefícios estiveram, razoavelmente, equilibradas no período de 1950 a 1993 com um pico de 19\% entre 1961 e 1965, que se verificou após a recessão de 1960 quando o salário de executivos das corporações norte-americanas tinha sido na proporção 20:1 em relação a um trabalhador comum da indústria, mas a partir de 1989 esta proporção que já havia crescido de 56:1 eleva-se para 116:1 em 1997, ou seja, mais que o dobro, em um breve período de apenas 8 anos, sob pertinaz orientação da política neoliberal.

A partir do quarto final de 2001 e o ano todo de 2003, os lucros corporativos de 40.5\% na fatia da Renda Nacional mais do que triplicaram em relação aos salários daquele período (1961-1963); havia sido o maior índice após a Segunda Guerra Mundial. A inclemência liberal e sem controle da concorrência global tem sido muito favorável aos lucros corporativos e aos salários de seus altos executivos denominados em inglês CEO's (Chief Executive Officers), mas bastante desfavorável para a grande maioria de 
trabalhadores, com perda salarial e as precarizações relativas de suas históricas relações de trabalho. No período de 1991 e 1993, os trabalhadores assalariados obtiveram uma melhor distribuição de renda, atrelado ao crescimento dos seus salários + benefícios como parcela do crescimento da Renda Nacional Americana, mas em função, principalmente, do aumento de horas trabalhadas que, em 1992, representara para o trabalhador peculiar estadunidense mais 163 horas de trabalho em relação a 1972, ou seja, o mesmo que 21 dias a mais de trabalho ao ano. O próprio salário mínimo em 1998 decresceu em média $22 \%$ a menos em relação ao de 1968 .

Quanto menor a relação na tabela Lucros Corporações/Salários, melhor a distribuição das rendas aos trabalhadores que recebem Salários + Benefícios.

O acúmulo extraordinário nas mãos de uma minoria tem influenciado a mudança para pior na situação não só dos trabalhadores estadunidenses, mas também daqueles outros que ficam à mercê da potestade do capital acumulado na perspectiva neoliberal globalizada. Para fazer frente à drástica competição internacional e para não perder mais terreno no mercado global, agem nesta perspectiva, usando instrumentos ortodoxos de economia localizada, a exemplo do que se fez magnificamente durante 25 anos após a Segunda Guerra Mundial.

À maneira de uma pessoa idosa que não consegue resolver satisfatoriamente seus problemas de saúde, claro que em função da inexorabilidade do tempo e da exigüidade física, mas também pelo histórico das suas atitudes em relação ao seu bemestar. Por mais que implementem novas técnicas, métodos e estudos não resolvem satisfatoriamente seus graves problemas e os resultados são paliativos, de curta duração como são características desta política neoliberal interagindo na rede internacional e que vem resultando neste estado de extrema dificuldade de resolução, situação que coloca a própria humanidade em risco.

São bastante conhecidos os sofrimentos mortificantes que a classe trabalhadora em geral tem suportado; em particular, os trabalhadores estadunidenses, tão capazes de trabalho, tão eficientes nos seus desígnios, mas pouco eficazes na condução da riqueza produzida, têm estado bem acomodados e condicionados e, de certa maneira, agora se encontram com as mãos atadas para reverter esta situação, incluindo a de sua própria indiferença. 
O interessante no mundo caótico é a desvantagem comparativa que se sobrepõe aos menos preparados, portanto o mais oportuno a fazer é usar a "navalha de Occam", partindo da alusão mais simples sem as contradições permitidas pelas teorias impostas de cima pra baixo, para que não nos iludamos mais e deixemos de lado o sofisticado e nos atenhamos ao mais relevante em tudo àquilo que realmente dignifique o trabalho social como forma de poder sustentar as instituições trabalhistas e seus instrumentos de luta em prol de uma sociedade e natureza mais equilibradas.

Atualmente, os sindicatos do setor privado têm contribuído de maneira menos eficaz para a melhoria do bem-estar social do trabalhador, atestado pela diminuição crescente de seus associados, evidenciando em parte um problema estrutural, quando muda a situação do emprego de setores da indústria fortemente sindicalizada para os menos sindicalizados, levando em consideração que a grande maioria dos empregadores estende automaticamente as condições dos benefícios acordados nos contratos coletivos para os não-sindicalizados, a fim de deixá-los fora dos sindicatos.

Os trabalhadores estadunidenses elegem uma unidade de barganha, mormente aliados a um sindicato industrial ou profissional, como representante legal para a negociação coletiva (Statutory Bargaining Representative), o que inevitavelmente acaba por afetar não somente os seus filiados, mas atinge a todos os trabalhadores daquela unidade legal de negociação (Statutory Bargaining Unit). A NLRA superintende a eleição secreta de representante exclusivo do Contrato Coletivo mediante uma petição de pelo menos 30\% dos empregados que, assim ajustados, ficam autorizados a eleger um representante (individual ou ligado a um sindicato) que deverá reunir então no mínimo $50 \%$ dos votos para a efetivação. Nas eleições, os trabalhadores têm a opção de eleger vários representantes ou podem optar pela não-representatividade exclusiva.

Existe um ressentimento histórico das empresas empregadoras em relação aos sindicatos de trabalhadores que retrata a luta heróica destes em face à intransigente força capitalista. Segundo consta no Censo de 2003-2004, aproximadamente 1/4 da população economicamente ativa, ou seja, aproximadamente 34 milhões de trabalhadores, não estão cobertos por Contratos Coletivos de Trabalho. ${ }^{13}$ Deste total, cerca de 8 milhões são empregados do setor público em 14 estados, 26 milhões do setor privado empregados nas indústrias, incluindo os trabalhadores da agricultura, empregados domésticos e outras

\footnotetext{
${ }^{13}$ Occupational Outlook Quarterly Winter, 2003-2004.
} 
categorias de baixo salário. Nota-se precarização das condições dos trabalhadores; aqueles que não pertencem às elites não alimentam quaisquer perspectivas de uma pensão decente no futuro, nem mesmo de um plano mínimo de saúde, pois dos 46 milhões de pessoas sem seguro de saúde, a maioria é de trabalhadores deselitizados (U. S. Census Bureau, 2005).

A tendência é recorrer a contratos temporários e de curta duração, regulados por uma tendência de maior imposição legal que se verifica com a diminuição da força de barganha dos sindicatos, contrariando toda a tradição de luta destes, mas de acordo com as práticas do sistema neoliberal como força política global, que dia a dia tornam bastante controvertida a proteção sindical local. A tendência avassalante de investir no preenchimento de empregos precários caracteriza o enfoque neoliberal, pois não se tratando de empregos regulares nega-se-lhes a proteção sindical.

De acordo com o jornal The Guardian, ${ }^{14}$ cerca de $1 \%$ das famílias no topo da pirâmide social norte-americana, recebeu $64 \%$ de aumento em seus rendimentos desde 1980 até 2000 , sendo que $65 \%$ das famílias não recebeu aumento e os $25 \%$ da parte mais baixa da pirâmide social teve seus salários diminuídos. Cerca de $1 \%$ da população mais rica detém $38 \%$ da riqueza e os $20 \%$ daquela ganha 9 vezes mais que os $20 \%$ da população mais pobre, o que caracteriza uma das sociedades mais desiguais do mundo industrializado ocidental, contrapondo arbitrariamente a ufania de sociedade justa, como imagem exemplar da maior democracia ocidental.

As relações trabalhistas no geral, tal como hoje são concebidas, tendem a valorizar a mão-de-obra não-sindicalizada e desqualificada nas fábricas automatizadas e que acabam garantindo a qualidade dos produtos a custos baixos com o uso de avançadas tecnologias em robótica. Com isso fazem frente à concorrência desenfreada e sem escrúpulos para atender à demanda de mercado criada; diga-se de passagem, inteiramente fictícia, no sentido que é insubsistente no longo prazo, mas em médio e curto prazo os resultados desta são deveras subsistentes no aprofundamento das vicissitudes das variáveis sociais e ambientais.

Obviamente que essas minorias elitizadas nos diversos países são, notoriamente, competentes para efetivar o sistema com o aumento de emprego de pessoas altamente qualificadas de renomadas universidades e que têm orientado eficazmente não só as

\footnotetext{
${ }^{14}$ The Guardian, edição de 28 de Abril de 2002.
} 
guerras econômicas entre nações, mas estratégias dominadoras, parecidas com aquelas já registradas pela história, à época em que títeres levaram os generais romanos a realizar proezas monumentais como se fossem os bastiões dos construtores de impérios.

\section{SalÁrio Alto EXecutivo X MÉdia TrabalHador COMUM}

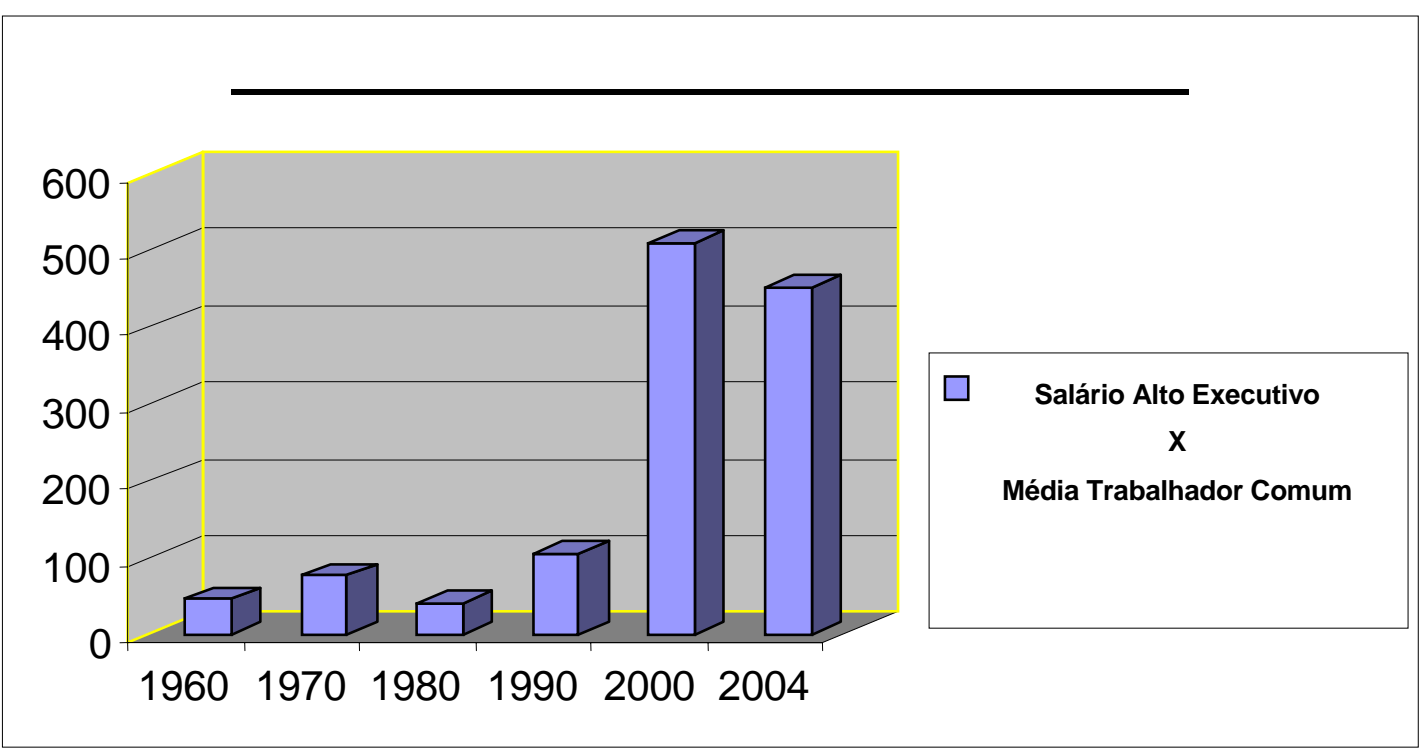

Fonte: U. S. Bureau of Labor Statistics. Business Week Annual CEO Pay Survey.

Observa-se no gráfico acima o crescimento salarial vertiginoso dos executivos das grandes corporações $(\mathrm{CEO}=$ Chief Executive Officer $)$ cujos salários médios em 1960 eram cerca de 41 vezes maiores que a média salarial do trabalhador comum. Já em 2004, eram 431 vezes superiores.

Atualmente, o avanço do neoliberalismo e o fortalecimento das corporações superpoderosas, que manipulam tudo o que possa alterar-lhes a lógica míope de excessiva acumulação, vem atuando em detrimento do povo trabalhador num formidável concerto de esterilização social! Eis um grande desafio para o homem do século XXI que não pode se curvar diante da desigualdade social; a fim de superar-se e poder fazer frente ao seu destino, a construção de uma sociedade mais equilibrada e sustentável, tornou-se ademais uma condição sine qua non para a sobrevivência. A título de ilustração, assim define Guy Debord: O espetáculo é o capital em tal grau de acumulação que se torna imagem. 
GANHOS POR OCUPAÇÃO DOS SINDICALIZADOS E NÃO-SINDICALIZADOS

NORTE-AMERICANOS EM 2001.

SALÁRIOS E REMUNERAÇÕES TEMPO INTEGRAL - MÉDIA SEMANAL

\begin{tabular}{|c|c|c|c|}
\hline OCUPAÇÃO PRINCIPAL & $\begin{array}{c}\text { SINDICALIZADO } \\
\text { LEGAL }\end{array}$ & $\begin{array}{c}\text { NÃO- } \\
\text { SINDICALIZADO }\end{array}$ & $\begin{array}{c}\text { DIFERENÇA } \\
\%\end{array}$ \\
\hline TOTAL & 718 & 575 & 25 \\
\hline EXECUTIVO, GERÊNCIA & 869 & 865 & -.4 \\
\hline PROFISSIONAL & 864 & 853 & .1 \\
\hline TÉCNICOS & 731 & 662 & 11 \\
\hline VENDAS & 559 & 575 & -3 \\
\hline $\begin{array}{l}\text { ADMINISTRATIVOS } \\
\text { ESCRITÓRIO }\end{array}$ & 597 & 472 & 26 \\
\hline SERVIÇOS - PROTEÇÃO & 809 & 518 & 56 \\
\hline SERVIÇOS - OUTROS & 426 & 333 & 27 \\
\hline ESPECIALISTAS & 822 & 590 & 39 \\
\hline OPERADORES, MÁQUINAS & 587 & 421 & 39 \\
\hline TRANSPORTE, MUDANÇA & 724 & 521 & 39 \\
\hline OPERÁRIO MANUAL & 530 & 369 & 44 \\
\hline FAZENDA, FLORESTA, PESCA & 587 & 345 & 70 \\
\hline
\end{tabular}

Fonte: Depto. Trabalho dos EUA - Empregos e Ganhos, Janeiro de 2003; preparado pela AFL-CIO.

Verifica-se pela tabela acima um esforço na interpretação estatística da AFLCIO (American Federation of Labor - Council of Industrial Organization) para comprovar, atualmente, as supostas vantagens da sindicalização, mais em função da campanha para reverter o quadro declinante de membros que se verifica na tabela da densidade dos quadros sindicais privados norte-americanos do que da situação real. Com efeito, não está devidamente demonstrado, de modo estrito, quanto de aumento salarial se deve aos sindicatos, em se comparando a remuneração que a eficiência do mercado competitivo poderia resultar numa economia de tendência global fortemente ascendente, e mais agravante, se considerarmos a quantidade de problemas sociais gerados pela 
destruição de empregos, afetando as bases de uma sociedade sustentável. Até quando o governo americano conseguirá contrabalançar esta situação é uma incógnita?

As indústrias de ponta, em determinados momentos de grande crescimento econômico, histórica e relativamente, remuneravam o fator trabalho humano de maneira bastante generosa bem antes da sindicalização ${ }^{15}$ de seus trabalhadores. Esta tendência, nem sempre bem observada, verifica-se nas modernas indústrias contemporâneas de ponta em tecnologia onde o esforço de cada um é reconhecido como importante para o desenvolvimento do capital humano da empresa.

A campanha da AFL-CIO de 1999 que objetivara o acréscimo de 1 milhão de novos membros por ano aos quadros sindicais fracassou. É nítida a vantagem que levam as minorias na sindicalização, mas os jovens brancos em profissões pós-industriais, literalmente não prescindem tanto dos sindicatos nos moldes como têm atuado. $\mathrm{O}$ dado relevante é que nas profisssões tradicionais, os que procuram a sindicalização são as minorias, os mais idosos e no item Serviço-Proteção estão incluídos membros de entidades de segurança pública que vêm descaracterizar o índice. Em 2002, cerca de 16 milhões de membros - somente $13,3 \%$ da força americana de trabalho $(8,6 \%$ no setor privado e $37,8 \%$ no setor público $)^{16}$ - pertenciam a sindicatos, sendo que a metade dos membros há pelo menos 30 anos e 1/3 há 60 anos.

\section{Membros dos Sindicatos nos Estados Unidos - 1930-1999}

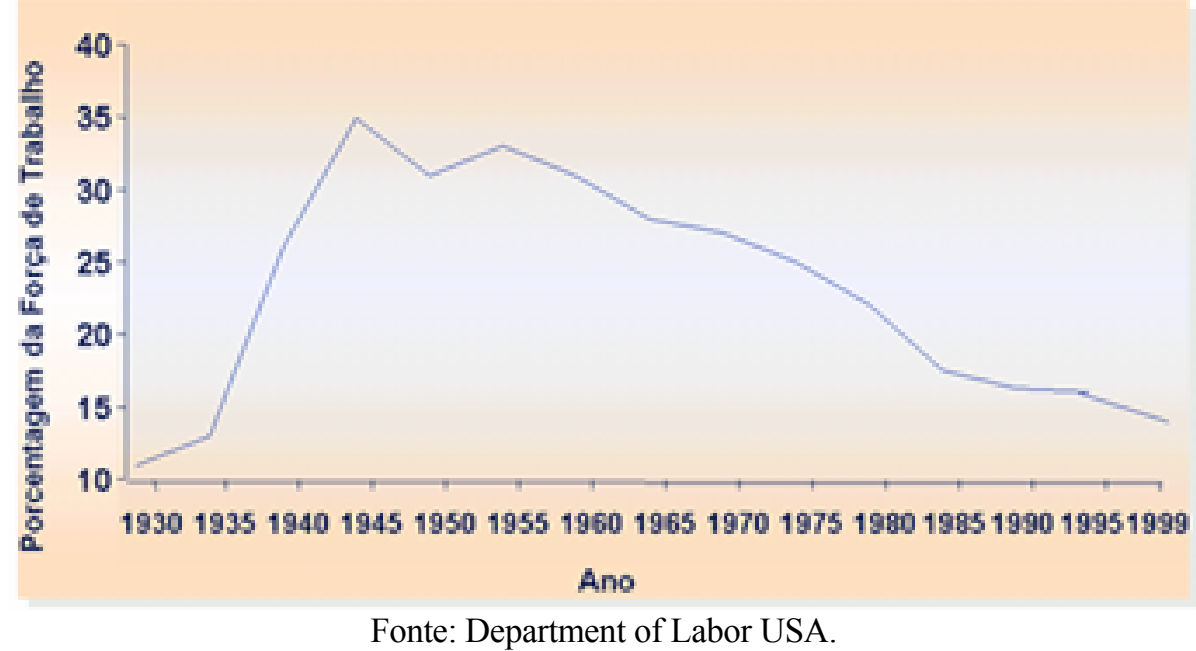

\footnotetext{
${ }^{15}$ Nos EUA existe uma tendência de sindicalização de apenas uma única empresa ou uma indústria.

${ }^{16}$ Extraído do periódico Statistical Abstract of the United States, 2003.
} 


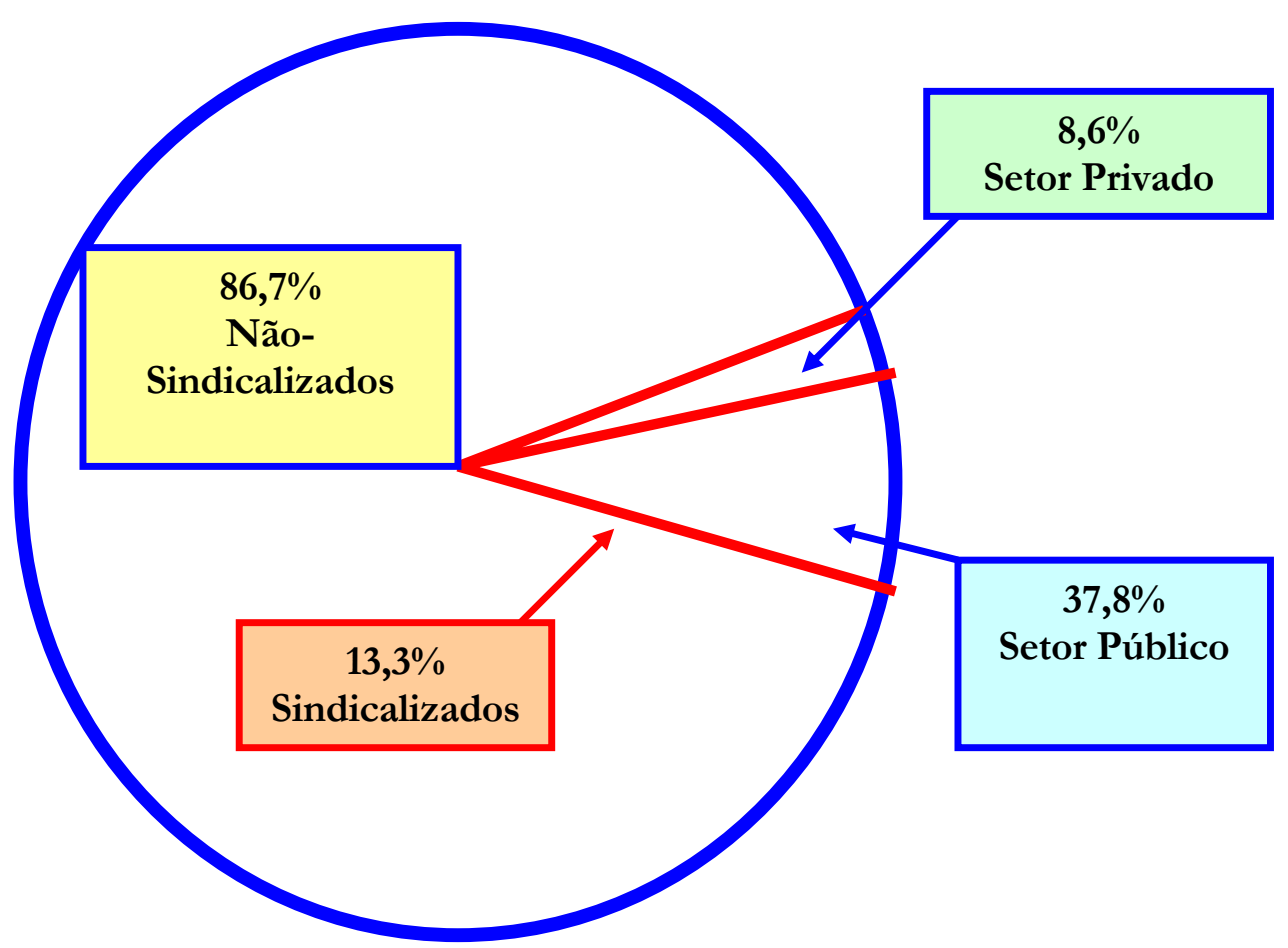

Fonte: Bureau of Labor Statistics - Statistical Abstract of USA, 2003.

O decréscimo ainda é constante; em 2006 há registro de que a densidade sindical do setor privado caiu para 7,4\%.

A maioria dos sindicalizados integra o conjunto de 13 milhões de trabalhadores membros da forte AFL-CIO (2003) que, atualmente, tem que lutar com o problema de como reverter o quadro de declínio e como mudar a atitude de aproximadamente 100 milhões de trabalhadores americanos não-sindicalizados. Além disso, muitos estados do sul que tiveram recentemente um desempenho econômico melhor que os do norte, têm leis que restringem muito mais as atividades dos sindicatos, ainda reflexo daquela sociedade escravocrata que sempre a caracterizou.

As políticas sindicais usuais recorrem pragmaticamente por aumentos salariais a fim de atrair novos membros em vez de procurar enfatizar uma maior mudança no paradigma social que pudesse dotar garantias mais estáveis no longo prazo, a título de como fazem muitos sindicatos europeus, em particular, os escandinavos. 
Nos Estados Unidos, há uma profunda disparidade entre negócios e trabalho, que o governo não resolve, tornando a oposição trabalhista menos integrada e mais politizada, sem equacionar, contudo, os graves problemas que se evidenciam para um futuro próximo.

Os direitos de sindicalização e de greve "de facto" não estão adequadamente protegidos na legislação trabalhista dos EUA, o que explica em parte o persistente declínio na sua densidade de membros efetivos. A lei é incapaz de proteger os trabalhadores quando o empregador está decidido a destruir ou evitar a representação sindical. Pelo menos um em cada dez ativistas que fazem campanha para formar um sindicato é despedido ilegalmente. Pelo menos um trabalhador será ilegalmente despedido em mais de $30 \%$ de todas as campanhas de sindicalização.

A oposição dos empregadores para a formação de sindicatos é notória; criam um clima de hostilidade que dificulta a organização. "Praticamente, todas as pesquisas acadêmicas mostram a oposição do empregador, legal ou ilegal, que é o elemento-chave para os sindicatos não se organizarem", afirmou o professor Adrienne Eaton da Universidade de Rutgers. Já o número exato de empregados que são demitidos ilegalmente, na tentativa de organizar um sindicato, é difícil de determinar, mas segundo apurou a Commission on the Future of Worker-Management Relations, ${ }^{17}$ conhecida como Comissão Dunlop de 1994, a National Labor Relation Board (NLRB) tem sido obrigada a solicitar a readmissão de cerca de 2.000 trabalhadores anualmente. Constatou-se também que $79 \%$ dos estadunidenses crêem que os trabalhadores se arriscam a serem despedidos se tratam de organizar um sindicato e $41 \%$ dos trabalhadores não-sindicalizados afirmaram que poderiam perder seu emprego nesta mesma tentativa.

Segundo estimativas do National Labor Relation Board havia, em 1995, cerca de 25.000 casos acumulados e atrasados em relação às práticas trabalhistas injustas, por parte dos empregadores, contra as atividades sindicais. $\mathrm{O}$ aspecto positivo é que a lei é soberana para assegurar alguns direitos trabalhistas básicos conquanto a essência esteja garantida pelo Contrato Coletivo, em que as partes sentam-se juntos e discutem suas reivindicações em termos dinâmicos, atuais e reais das condições diversas daquele momento e lugar específicos. Claro que abusos gritantes, como é comum nas relações

\footnotetext{
${ }^{17}$ USA Federal Commission on the Future of Workers and Management Relations. The John T. Dunlop Commission on the Future of Worker-Management Relations - Final Report.1994. Disponível em http://digitalcommons.ilr.cornell.edu/key workplace/2.
} 
capital x trabalho, devem ser julgadas por um poder moderador supostamente isento e neutro. Este poder moderador é representado pelos mediadores (mediator, go to mediation) e árbitros (arbitrator, go to arbitration) os quais podem ser públicos ou privados dependendo do acordo prévio entre as partes conflitantes.

PORCENTAGEM DE TRABALHADORES SINDICALIZADOS - EUA (1983-2004)

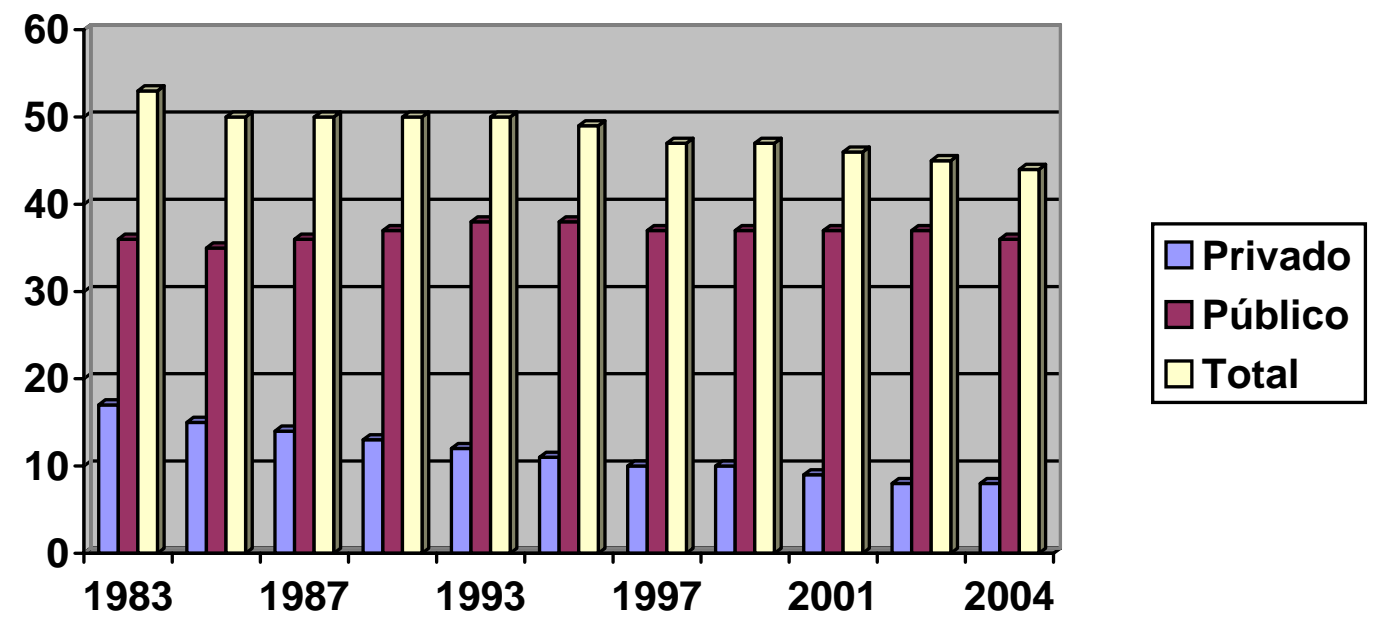

Fonte: Bureau of Labor Statistics

Por outro lado, o sindicalismo do setor público encontra-se em plena estabilidade, tanto nos países centrais como nos periféricos, evidenciando sua força no suporte tácito que dão às forças políticas, pois graças à estabilidade, segurança e privilégios tornam-se especialistas dos caminhos que a máquina administrativa tem a oferecer, mormente nos países de desenvolvimento capitalista secundário onde as forças políticas ainda não estão adequadamente estruturadas. Salientando aqui que, antes de 1960, os sindicatos de trabalhadores públicos estadunidenses, exceto os federais, não tinham instrumento legal para se organizar e formalizar um Contrato Coletivo de Trabalho. Sua organização aconteceu de maneira voluntária por seus membros que, na maioria das vezes, contavam com uma minoria disposta a enfrentar as forças políticas constituídas e quase sempre contrárias à efetivação de sua união. Mais de $40 \%$ dos empregados do setor público não têm o direito legal de se organizarem.

Num primeiro momento, o sistema neoliberal não tem afetado tanto o emprego do setor público como o do setor privado, mas com a crescente efetivação do estado mínimo, tais prerrogativas tendem a ser, gradativamente, inseridas dentro das perspectivas de maior eficiência e competência corporativas. 


\subsection{Sindicalismo no México}

Foi no período marcado pela guinada da terceira revolução industrial ocorrida nas últimas décadas do século XX que o México assistiu de maneira interessante à evolução dos "Contratos de Proteção" (Contratos de Protección). Estes contratos dominam as relações trabalhistas contemporâneas; têm origem no corporativismo que caracterizou os anos 30, firmando-se a partir dos anos 40 do século passado como forma de incentivar e proteger os capitais de investimentos dos grandes conglomerados capitalistas, por isso os "Contratos de Proteção" representam um instrumento do sindicalismo pelego (os mexicanos chamam de "charro").

Los contratos de protección han sido una respuesta que gobierno y patrones han encontrado para preservar esquemas de acumulación y de relaciones obreropatronales muy conservadores en los cuales han sustentado altas tasas de ganancia y de subsidiaridad por parte de los trabajadores, sin cuestionarse sobre las conveniencias de sustituir estos esquemas por fórmulas que garanticen no sólo mayor competitividad, niveles de acumulación y de productividad, sino también contratos sociales más equitativos y representativos para el factor trabajo. ${ }^{18}$

Os verdadeiros Contratos Coletivos de Trabalho representam, aproximadamente, menos de $10 \%$ de todas as relações contratuais do trabalho, abrangendo somente um número limitado de trabalhadores inter-relacionados aos sindicatos mais autênticos, pois tal situação confirma que esta relação tem sido marginal desde bem antes da lei federal do trabalho (LFT) mexicana de 1931, quando se formalizaram as relações jurídicas de trabalho. O mundo globalizado sob a égide neoliberal tem tornado, não só os Contratos Coletivos de Trabalho, mas os próprios instrumentos normativos, figuras jurídicas mais polêmicas. O que se assiste aqui é uma mistura de influências neocorporativistas em contraste com a forte cultura inerente ao universalismo que caracteriza o revolucionário povo mexicano. Da parte investigativa, seria ingênuo relegarmos para segundo plano a influência das grandes corporações transnacionalizadas na formulação de políticas nacionais que determinam a precarização

\footnotetext{
${ }^{18}$ LÓPES, Maria Xelhuantzi. La democracia pendiente: la libertad de asociación sindical e los contratos de protección en México. México: Sindicato de Telefonista de la República Mexicana, 2000, p. 61.
} 
da política trabalhista vigente, pois, a partir do fim dos anos 70, o desdobramento dos Contratos de Proteção verifica-se também nas empresas prestadoras de serviços.

Segundo López, existem cerca de 600.000 Contratos Coletivos de Trabalho registrados no país, dos quais 107.000 contratos na capital federal, mas destes, somente 17.000 são revisados anualmente. ${ }^{19}$ Parece que os Contratos de Proteção $(\mathrm{CP})$ na capital federal têm uma porcentagem maior que a média nacional de $10 \%$, pois estão em torno de $15 \%$ os que se revisam a cada dois anos de acordo com o que determina a LFT.

Afora as contradições sobre o número exato de Contratos Coletivos de Trabalho depositados na Junta Federal de Conciliação e Arbitragem, que se justifica com a alegação de que tal prática possibilita a continuidade da interlocução dos debates intersindicais, na realidade revela a carência de fontes abertas e confiáveis que origina este clima de clandestinidade. A reforma da LFT tem sido a bandeira levantada pelas empresas no intuito de despojar os índices reais de produtividade, precarizando ainda mais a relação capital/trabalho.

Ressalta-se que mais de $90 \%$ dos contratos de trabalho são, de fato, Contratos de Proteção habilmente elaborados por experientes advogados trabalhistas. Convencionou-se chamar de sindicatos de proteção, as alianças que estes efetuam entre o governo, com favores políticos, e as grandes empresas no que tange à titularidade na negociação do $\mathrm{CP}$. O Contrato de Proteção é assinado de acordo com o conluio convencional entre governo, empresas e sindicatos servilões, que entre outros condicionantes, previnem-se na formação de sindicatos independentes e autênticos que pormenorizariam os direitos e obrigações a que um verdadeiro CCT deveria pautar-se para que se pudesse efetivar uma melhoria com mais equilíbrio nas relações laborais. Segundo o sindicato dos aeronautas do México, na prática usual, são os empregadores, por vezes assessorados pelo próprio governo, que escolhem o sindicato de acordo com suas predileções ao entabular a negociação de um CP, fato que dificulta e até mesmo impede aos trabalhadores a escolha vindoura de um sindicato autêntico. Tal fato ocorre pelo favorecimento da lei quanto à cláusula leonina de exclusão (close shop). ${ }^{20}$

Apesar de a Suprema Corte mexicana tê-la confirmado ilegal em 2001, tal procedimento ainda não corrobora poder sancionador devido a dependência de outras

\footnotetext{
${ }^{19}$ LÓPES, Maria Xelhuantzi. Op. cit., p. 120.

${ }^{20}$ Modelo em que empregadores somente contratam membros de certos sindicatos, determinando, mais apropriadamente em termos jurídicos, um contrato precário.
} 
resoluções ainda não apreciadas por aquele órgão, deliberando, na prática, a sua impermanência. Por exemplo, a Corte Suprema determinou a inconstitucionalidade, dois anos depois, ao prazo em que o tempo útil de uma greve deveria se pautar, contrariando as condições impostas pela Junta de Conciliação e Arbitragem aos diversos sindicatos. Para um empregado ser desligado de um sindicato, há necessidade de votação de seus correligionários, mas tal exigência quase sempre é descumprida, o que comumente resulta em sua dispensa compulsória, sem direito à indenização.

Enquanto os Contratos de Proteção atrelados aos mesmos sindicatos incrementam-se, os verdadeiros CCTs ligados aos sindicatos autênticos diminuem, haja vista a redução média de $18 \%$ de sindicalização nos últimos 20 anos que, entre outras razões, destacam-se o expressivo aumento das subcontratações e dos cargos de confiança nos setores público e privado, características do novo modelo de relações de trabalho que o neoliberalismo impõe, descaracterizando e procurando tornar as leis trabalhistas superadas no sentido de abstrair a proteção ao hipossuficiente, em se comparando com a dinâmica cumulativa do capital. A partir dos anos 80 , com o neoliberalismo firmando-se de maneira mais incisiva na flexibilização das relações trabalhistas, os "Contratos de Proteção" estenderam-se ao setor terciário atingindo as empresas de pequeno e médio porte com as subcontratações, terceirizações e contratos provisórios. As propaladas reformas trabalhistas que advêm de tais fatos, sempre trazem no bojo de suas conjecturas perdas reais para os trabalhadores.

A legalidade pela qual os sindicatos de proteção são reconhecidos é a facilidade do seu registro, porque a lei mexicana não abona de antemão a validade dos votos efetuados pelos sindicalizados para que seja efetivada, é realizada através de um processo viciado, enfadonho e moroso.

Dentre os poucos organismos internacionais que realmente se interam da realidade na tentativa de melhorar as condições humanas nas relações de trabalho, a maioria destes institutos ou organizações internacionais ligadas ao estudo das relações trabalhistas, ao analisarem o óbvio procuram desviar a atenção das suas reais intenções de domínio, para que nas horas oportunas e incertas do futuro, seus interesses mediatos sejam preservados de acordo com a agenda liberal acintosamente aplicada aos países que ainda (ingenuamente) sonham com um futuro mais promissor. 


\section{ORGANIZAÇÕES TRABALHISTAS MEXICANAS \\ (Breve Painel)}

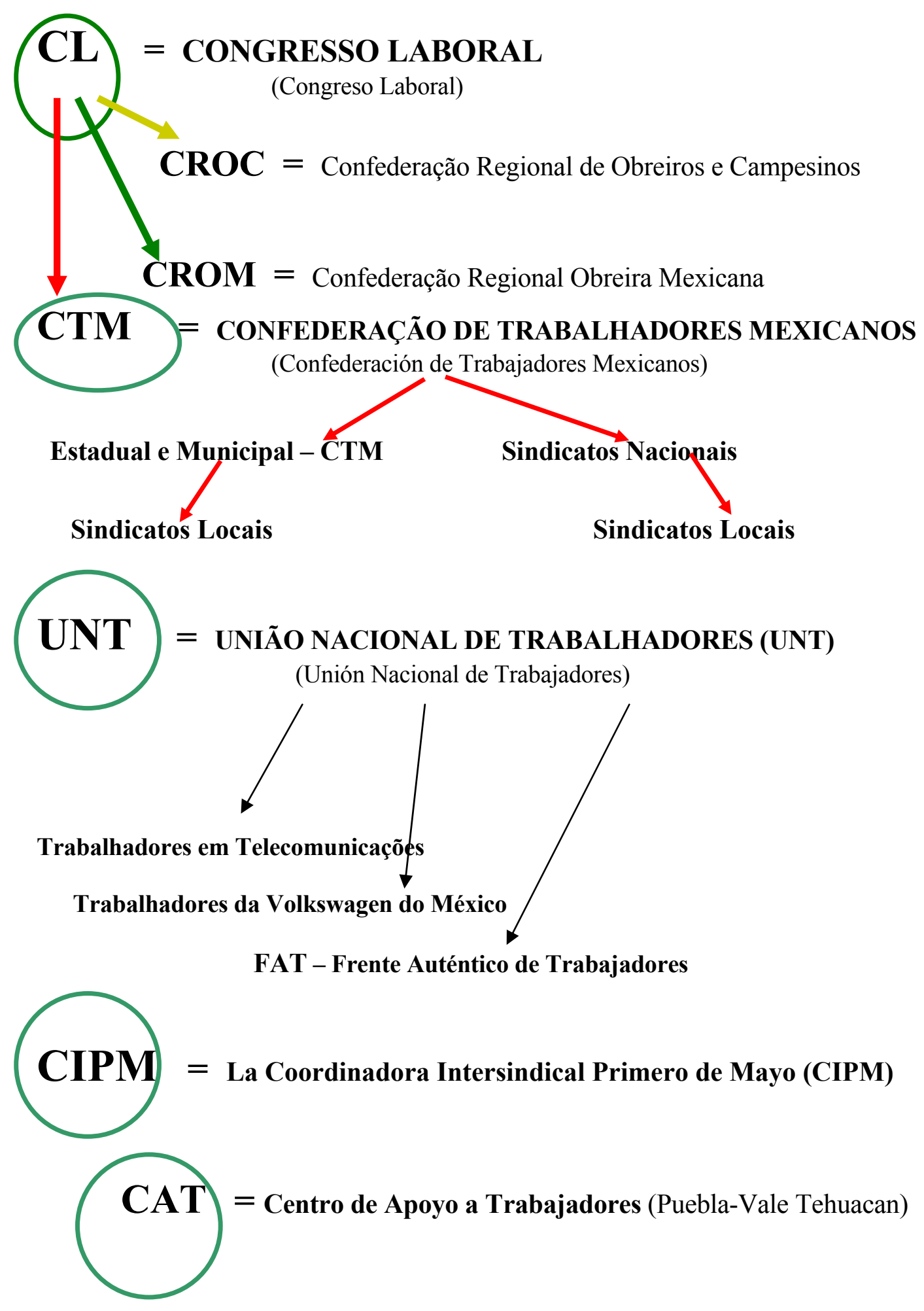


De acordo com estatística da Secretaria do Trabalho e Previsão Social (STPS) de 2003, a população economicamente ativa (PEA) no México era 40.633.197 de trabalhadores. Segundo o Instituto Nacional de Estatística, Geografia e Informática (INEGI) existem cerca de 1.200.000 trabalhadores ambulantes junto a outros na informalidade.

O velho Congreso Del Trabajo (CT), controlado pelo Partido Revolucionário Institucional (PRI), declara possuir, aproximadamente, $12.500 .000(\boldsymbol{\&})$ trabalhadores, sendo que a:

- CTM congrega cerca de 4 milhões de trabalhadores em 140.000 empresas (média de 29 empregados por empresa). Esta confederação foi dirigida pelo legendário líder sindical nonagenário Fidel Velázques desde os anos 40 até os anos 90 do século passado.

- Federação de Sindicatos de Trabalhadores a Serviço do Estado (FSTSE): congrega cerca de 2 milhões de trabalhadores em 83 sindicatos regulamentados pelo parágrafo B do artigo 123 da Constituição.

A União Nacional de Trabajadores (UNT), fundada em 1997, congrega 160 Federações de Trabalhadores independentes com cerca de 1.500 .000 (Um milhão e quinhentos mil) trabalhadores segundo suas próprias fontes. A UNT caracteriza-se com a premissa do sindicalismo tradicional estadunidense, ou seja, de não se filiar a nenhum partido político, mas de apoiar partidos e candidatos que lutem pela causa dos trabalhadores. Sua plataforma de insubmissão do sindicato em face do partido que detém o poder político, e a luta por uma democracia sindical mais um programa econômico opcional ressaltaram a expectativa de uma atuação mais decisiva dos trabalhadores na luta pelos seus direitos fundamentais. A necessidade de uma opção econômica que desse aos trabalhadores uma perspectiva mais alentadora frente a precarização das relações trabalhistas que vem resultando na expressiva debilitação dos sindicatos, com o desvanecimento dos verdadeiros Contratos Coletivos de Trabalho.

De acordo com o primeiro congresso nacional da CIPM em 1997, concluiu-se que esta frente heterogênea formou-se, inicialmente em primeiro de maio de 1995 frente a uma forte crise econômica, como uma comissão coordenadora entre sindicatos mais 
autônomos, ligas camponesas, grupos políticos de esquerda e movimentos populares. Nesses anos iniciais serviu aos propósitos de luta e política sindical contra o arrocho capitalista, atendendo à parcela de insatisfeitos que, desde os anos 70, insurgiram-se contra o modelo ortodoxo dominante, denominando-se sindicalistas independentes e cujas convicções políticas e sociais já vinham se formando desde as conflituosas repreensões aos sindicatos no final dos anos 50 do século passado.

A maioria dos membros da CIPM faz parte da Frente Sindical Mexicana (FSM) formada em 1988 como resposta ao neoliberalismo e à pretensiosa reforma trabalhista ainda em curso, mas com tendência bastante clara de arranjo institucional, estrategicamente planejada pela elite empresarial e governo, tendo em vista os interesses corporativos transnacionalizados e o pacto laboral firmado pelo NAFTA, denominado North American Agreement on Labor Cooperation (NAALC).

De acordo com dados do congresso de 1997, a CIPM foi composta de 765.000 afiliados dentre as diversas associações trabalhistas, o que representava cerca de $9 \%$ dos trabalhadores agrupados em associações sindicais. A maioria dos sindicatos membros da CIPM também faz parte como membro da UNT, mas a CIPM se recusa a participar como organização de per si, por ter um olhar menos ortodoxo da situação sindical e estar mais voltada aos ideais da Frente Zapatista de Libertação Nacional (FZLN), ainda que setores mais radicais da CIPM não vislumbrassem o movimento zapatista como uma verdadeira luta de classes. Sindicatos tradicionais e fortes, mormente ligados à comunicação e serviços públicos, são constantemente criticados por membros da CIPM pelas suas alianças políticas mais conservadoras.

O FAT é uma agremiação sindical autêntica que surge em cena em 1960, cuja década caracterizara o otimismo econômico e o bem-estar social, mas que em longo prazo não correspondeu àquelas condições, nem ao estado objetivo da economia que prevalecera naqueles efusivos anos. Teve posição chave resolutiva dentro da UNT a proposta, logo no primeiro ano, de uma liderança coletiva composta de 3 membros, em vez de um secretário geral que no sistema mexicano é o mais alto grau de comando dentro de uma agremiação sindical.

Os dados estatísticos acima, com exceção dos dados da Secretaria del Trabajo y Previsión Social abaixo são: ? (contraditórios); ! (não confiáveis); $\underline{\boldsymbol{\&}}$ (tendenciosos), conforme convenção simbólica já mencionada no começo do presente trabalho. 


\begin{tabular}{|c|r|r|r|}
\hline \multicolumn{5}{|c|}{ POPULAÇÃO ECONOMICAMENTE ATIVA } \\
\hline OCUPAÇÃO & 1999 & 2001 & 2003 \\
\hline Empregadores & $1.597,282$ & $1.738,661$ & $1.632,724$ \\
\hline $\begin{array}{c}\text { Trabalhadores/ } \\
\text { Conta própria }\end{array}$ & $9.391,538$ & $9.477,269$ & $10.177,552$ \\
\hline Assalariados & $23.863,352$ & & $24.748,809$ \\
\hline Outros & $4.101,165$ & $3.422,766$ & $3.463,676$ \\
\hline TOTAL & $\mathbf{3 8 . 9 5 3 , 3 3 7}$ & $\mathbf{3 9 . 3 8 5 , 5 0 5}$ & $\mathbf{4 0 . 6 3 3 , 1 9 7}$ \\
& & & \\
\hline
\end{tabular}

Fonte: Secretaria del Trabajo y Previsión Social.

O CT congrega 34 federações de todos os ramos da economia onde se destacam, pela afluência de grande quantidade de membros e força política, as seguintes:

- CTM Confederación de Trabajadores de México

- $\quad$ FITSE Federación de Sindicatos de Trabajadores al Servicio del Estado

- $\quad$ STPRM Sindicato de Trabajadores Petroleros de la Republica Mexicana

- SNTE Sindicato Nacional de Trabajadores de la Educación

- $\quad$ FENASIB Federación Nacional de Sindicatos Bancarios

- CROC Confederación Revolucionaria de Obreros e Campesinos

- CROM Confederación Regional Obrera Mexicana

- COR Confederación Obrera Revolucionaria

- FTDF Federación de Trabajadores del Distrito Federal

- ANDA Asociación Nacional de Actores

A UNT congrega várias organizações entre as quais destacam-se:

- STRM Sindicato de Telefonistas de la Republica Mexicana

- FNSU Federación Nacional de Sindicatos Universitarios

- $\quad$ SNTSS Sindicato Nacional de Trabajadores del Seguro Social

- SME Sindicato Mexicano de Electricistas

- CIOAC Central Independiente de Obreros Agrícolas y Campesinos 


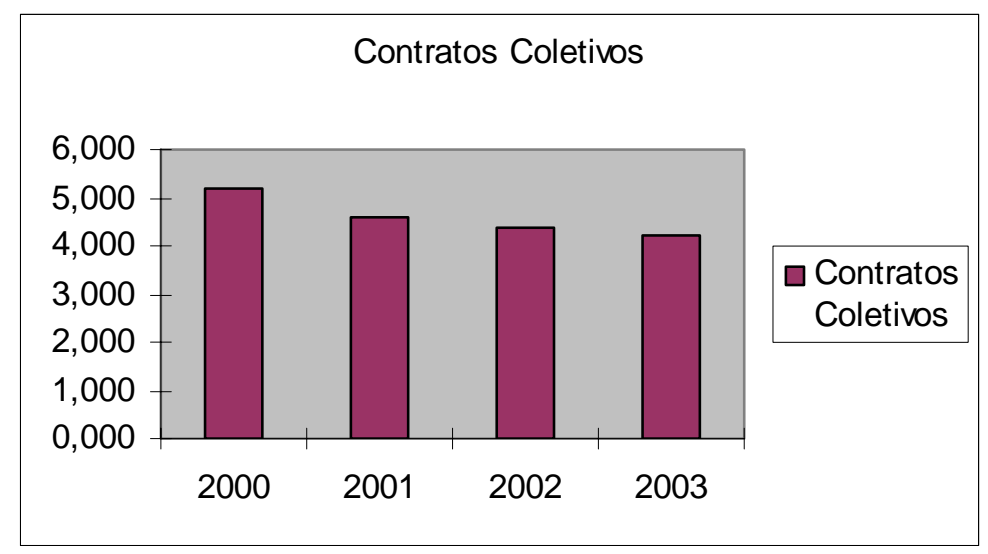

Fonte: STPS (JFCA)

Frente à forte têmpora do corporativismo ainda resistente, mas menos homogêneo do movimento trabalhista e as atitudes opostas à atuação revolucionária do proletariado da UNT, surgem grupos dispersos independentes de trabalhadores mais conscientes das novas formas de relações de trabalho advindas da produção transnacionalizada que caracteriza o neoliberalismo, como o Centro de Apoyo a Trabajadores (CAT), organização não-governamental da cidade de Puebla de los Angeles, que procura conscientizar os trabalhadores quanto à necessidade de representação verdadeira e sindicatos livres de quaisquer ingerências para a defesa dos direitos trabalhistas, dentre os quais a autenticidade de um Contrato Coletivo de Trabalho.

O CAT revela-se numa luta constante em não se ajustar somente a uma simples melhoria da condição econômica dentro do sistema, mas procura formas de luta mais de acordo com o realismo econômico que exterioriza o transnacionalismo da produção corporativa exemplarmente refletida nas "zonas maquiladoras" em que impera a precariedade das relações de trabalho e os preconceitos de raça e gênero. O CAT foi constituído formalmente em maio de 2001 como organização civil democrática e solidária, tem-se incumbido de dar respostas às violações dos direitos mais fundamentais em matéria de trabalho em que as "maquilas", não só da região do estado de Puebla têm estado submetidas. ${ }^{21}$ A cidade de Puebla está caracterizada por três regimes de desenvolvimento econômico, de caráter não-sustentável, na produção transnacionalizada

\footnotetext{
${ }^{21}$ Este termo derivado de maquila e de raiz árabe "mak-la" (medida) refere-se ao preço que se cobrava para beneficiar grãos e que hoje identifica as indústrias especializadas em importar matérias-primas ou pouco elaboradas, que exploram mão-de-obra local com a produção orientada para a exportação. O autor desta tese esteve em Puebla em setembro de 2004 e sua estada foi congraçada pela estimulante entrevista com Srta. Blanca Velásquez Díaz (Coordenadora e Relações Exteriores), Srta. Gabriela Cortez Cabrera (Cultura e Finanças) e o membro do Centro de Apoio a Trabajadores, Sr. Ivan de Erique.
} 
voltada à exportação de bens que requerem elaboração mais intensiva de mão-de-obra direta:

- Agrupamentos industriais engendrados em diversas regiões como a indústria automobilística e suas ramificações.

- Regime de zona "maquiladora" caracterizado pelo deslocamento da produção final, de elaboração mais extensiva, a outros horizontes, incentivado por atividades comerciais conjuntas elaboradas nos EUA e aplicadas no México.

- Ora concentração, ora difusão da laboração produtiva em espaços geográficos adversos, mas ricos em matérias-primas que são exploradas de modo automático, contribuindo para o desenlaçamento na criação de empregos e a péssima distribuição de renda, onde $43 \%^{22}$ da população vive com menos de 2 salários mínimos, contrapondo a sensatez que deveria prevalecer em um estado que tem tido participação significativa na produção da riqueza nacional.

Espera-se que o estado de Puebla, em fase de reestruturação produtiva devido às atuais condições de competitividade instigadas pelo mercado globalizado, releve aqueles aspectos na sua disposição de incrementar maior autonomia ao mercado de trabalho para possibilitar a geração de empregos estruturais capaz de atender sua demanda; caso contrário, o sistema econômico aprofundará ainda mais as espécies de acumulação capitalista e exclusão que causa a marginalidade social, cuja atuação na sociedade mexicana vem ocorrendo desde há muito tempo.

Esta zona "maquiladora" representa mais de $10 \%$ do total de $700.000^{23}$ empregos em nível nacional das indústrias de confecção no país. Estas zonas são notoriamente conhecidas como intolerantes à formação de sindicatos autênticos na representação dos trabalhadores, como exposto em viva voz pelo CAT, pois são frutos da exploração do trabalho que caracteriza a produção transnacionalizada quando tiram proveitos de situações em que os trabalhadores são vistos como simples peças sobressalentes de mercado. Caso que evidencia tal fato foi, segundo o CAT, a empresa maquiladora Tarrant que é do grupo Tarrant Apparel Group (TAG), parte de um

\footnotetext{
${ }^{22}$ Anuário Estatístico do Estado de Puebla, INEGI-2000.

${ }^{23}$ Dados do INEGI-2004: as estatísticas oficiais não dão conta do trabalho clandestino oferecido às "maquilas", prática muito comum na América Latina, portanto, dados referentes à geração tanto quanto à destruição de empregos não são devidamente apuradas de acordo com esta realidade.
} 
conglomerado com sede na cidade de Los Angeles (EUA). Esta "maquiladora" TarrantAjalpan produz jeans para vários destinatários, dentre os quais, a empresa Levi's Company, Abercrombie \& Fitch, Limited Brands, Charming Shoppes, Federated Department Stores, Tommy Hilfiger etc. Como sói acontecer tradicionalmente nas relações do capital versus trabalho, as diversas violações trabalhistas desta empresa fez com que cerca de 728 empregados, de um total de 1100, assinassem, em 19 de julho de 2003, uma petição à Junta de Conciliação e Arbitragem de Tehuácan para o reconhecimento de um novo sindicato independente que se chamaria Sindicato Único Independente de Trabalhadores da Empresa Tarrant (SUITTAR), sob a alegação, dentre várias, da necessidade de um Contrato Coletivo de Trabalho mais autêntico, pois aqueles que estiveram em vigência eram, na realidade, Contratos de Proteção ligados a sindicatos de proteção dos interesses corporativos.

O fato é que o pedido foi negado e até aquela oportunidade encontrava-se em situação pendente por questões aparentemente burocráticas, mas quando submetido a um olhar mais crítico, revela-se que por trás de tais acontecimentos, existe uma luta incansável pela sobrevivência destes indígenas e mestiços, pois lhes falta o básico para a sua preservação, sendo que o clamor que trazem imbuídos no âmago de seus espíritos, reflete a forte cultura exemplar de luta pelos seus valores autênticos e transparência, que o processo de produção transnacionalizada, em conivência com autoridades locais, desconhece como verdadeira a natureza sui generis deste povo admirável e imprevisível. Tais sindicatos (Sindicatos de Protección) são usualmente acobertados e o conteúdo dos contratos de trabalho desconhecido de todos os trabalhadores. ${ }^{24}$

O CAT organizou sua estratégia internacional com a procura de aliados para denunciar estas práticas trabalhistas que explicitam a imagem verdadeira destas empresas em que setores submissos da nova mídia globalizada, financiadas pelos interesses embutidos em tal relação, tão bem as vêm dissimulando. Após várias manifestações de aliados internacionais em defesa dos trabalhadores desta "maquiladora", as transações comerciais inter e intratransnacionais foram revistas desde que poderiam afetar a imagem de seus produtos no mercado. Os diversos casos têm tido um desfecho favorável aos

\footnotetext{
${ }^{24}$ Durante minha estada em Puebla, após a entrevista com o CAT, dirigia-me para os portões de algumas fábricas e apresentava-me a algumas trabalhadoras e acompanhava-as aos seus locais de morada para ter uma idéia mais real das péssimas condições de habitação que têm estas nativas.
} 
interesses corporativos, pois as empresas transferem-se para outros locais onde tais inconveniências, segundo sua ótica, não estão ainda conscientizadas.

A empresa Tarrant-Aljapan fechou sua fábrica de Puebla em fevereiro de 2004, bem como todas as outras fábricas no México, destruindo pelo menos cinco mil empregos. As empresas megacorporativas usam tal tática para tirar maior proveito deste interregno com uma maior acumulação de capital e assim poderem fazer frente à desenfreada, caótica, nefasta e propositada competição globalizada, cujo resultado tem sido apreciado somente na retrospectiva histórica. Quando não é mais possível tirar vantagens competitivas através de ausências ou violações das leis trabalhistas e ambientais, as empresas megacorporativas transferem-se para localidades onde tais e outras ignomínias ainda não são observadas. Segundo relatório da UNCTAD (United Nations Conference on Trade and Development) de setembro de 2004, cerca de 532 "maquiladoras" deixaram o México entre 2000 e 2003, ocasionando a notável perda de aproximadamente 280.000 empregos.

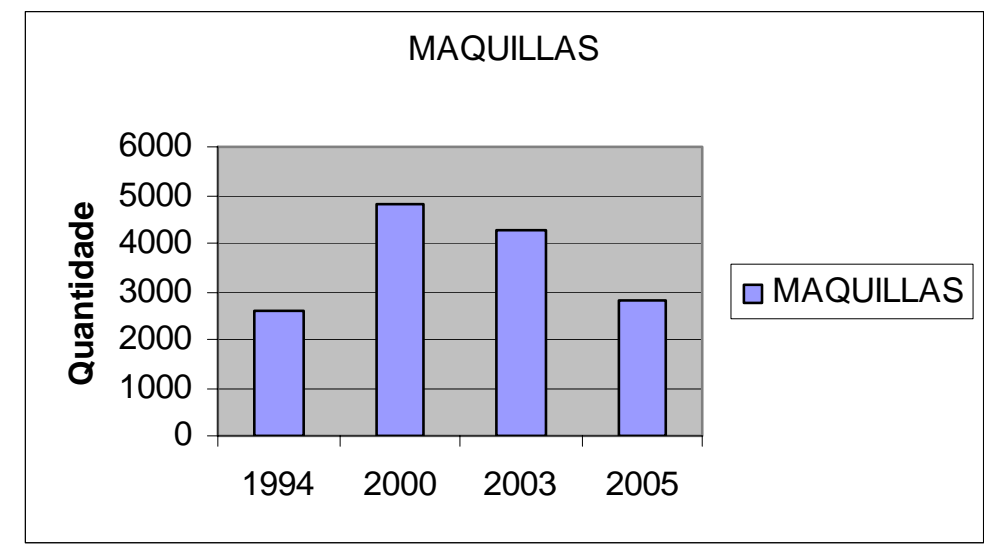

Fontes: National Labor Committee (2005); UNCTAD (2004).

Em 2000, os componentes montados no México através de "maquillas" perfizera um total de $90 \%$ das exportações às suas matrizes no EUA, em 2004, aquele montante caíra para $69 \%$ por causa das transferências a outras regiões da América Central e Caribe com um aumento retrospectivo de $28 \%$ na região asiática.

Estas empresas transnacionais investem em locais de pouca ou nenhuma organização trabalhista autêntica, legislação ambiental e mão-de-obra barata transferindose para regiões da China, Índia, América Central e Caribe, onde os salários estão abaixo dos US\$ 0,70 por hora, média nas zonas maquiladoras do México. De acordo com 
pesquisas em 2005 do National Labor Committee, os salários em Honduras são US\$ 0,65 por hora, na Nicarágua US\$ 0,41 e no Haiti US\$ 0,30.

Segundo apresentação em 2003 do professor Huberto Juárez Núñez da Universidade Autônoma da cidade de Puebla de los Angeles, o trabalhador chinês experiente é remunerado na média anual em US\$2.000 e no México em US\$ $3.300 \mathrm{sem}$ bônus e outros benefícios. A grande reserva de mão-de-obra que ainda existe naquelas regiões sinaliza em médio prazo uma perda maior de empregos nas zonas "maquiladoras" ou a opção de descer ao patamar de salários dos Chineses, com maior precarização das leis trabalhistas, segurança social, distribuição de rendas e incremento da corrupção, explicitado na frase "corrida global para baixo". 25

A tentativa de reverter este quadro da lógica neoliberal em que o capital privatizado, liberalizado e desregulamentado sobrepõe-se às implicações sociais e ambientais fazendo com que países concorram entre si na oferta de mão-de-obra, de acordo com a preocupação capitalista de reverter a queda da taxa de lucro, com um mínimo de concernência quanto aos valores humanísticos e ambientais, revelando-se no longo prazo a persistente insustentabilidade do sistema. Tal perspectiva faz-se desenvolver ainda mais a disputa da conglobação financeira instigada pelos fundos de pensão, mercado acionário e o mercado negro com suas falcatruas insondáveis que vêm caracterizando o mundo globalizado sem restrições. Dentro deste cenário, "urge"26 edificarmos uma utopia ${ }^{27}$ - a Cosmocracia, ${ }^{28}$ na qual a compreensão será a nossa principal ferramenta da mudança, esta mesma que já temos erigida em nosso espírito.

\footnotetext{
${ }^{25}$ Global Race to the Bottom.

26 "Dentro de este escenario, urgid edificar la Cosmocracia donde la comprensión será nuestra principal herramienta de la mudanza, esta que ya tenemos erigido en nuestro espíritu". Considere o uso do imperativo afirmativo em espanhol, pois em português ainda não há convenção.

${ }^{27}$ Talvez fosse melhor o termo heterotopia, conforme definido por Michel Foucault, que é o contra-espaço a meio caminho da percepção do sentido a que, uma realidade ainda difusa e necessária, se delineia no horizonte não tão distante das que caracterizam as tradicionais utopias. As heterotopias são contraespaços inquietantes e deslocados que permitem visualizar, de maneira incomum, a percepção de uma nova realidade que possibilitaria a perspicuidade necessária para a construção do novo.

${ }^{28}$ Dada a importância da "Cosmocracia" como solução possível das injustiças sociais, independentemente de apresentarmos explicação ad hoc, diríamos de modo preliminar que a mudança de tal quadro tenderia a consolidar valores atualmente defendidos por segmentos sociais inconformados com a situação atual e suas conseqüências nefastas, com a finalidade de preservar a dignidade humana. Seria preciso que tais valores se tornassem legalmente protegidos e fossem criadas novas instituições (ou não?) para que se implementasse a "Cosmocracia" como novo sistema político que conduzisse as relações sociais, em especial as de trabalho para garantir um maior equilíbrio e harmonia destas relações. Este ideal regulador foi inspirado a partir da filosofia univérsica criada pelo professor Huberto Rohden. Tradicionalmente, "revolucionários" se opõem a "reformistas", pois consideram que os últimos são conservadores; porém, após a derrocada do comunismo à esquerda política sobrou apenas a possibilidade reformista pela qual
} 
$\mathrm{Na}$ ânsia de auferir maior desenvolvimento econômico, os governos municipais mexicanos vêm oferecendo às "maquilas" todo tipo de incentivos, desde a oferta gratuita de terrenos, redução de impostos, e mão-de-obra barata que com a conivência, ineficiência ou mesmo ausência das autoridades trabalhistas formaram o quadro favorável para a instalação das "maquilas". Apesar de todos os esforços do governo mexicano, reduzindo ainda mais as taxas e o imposto de renda, não tem conseguido reverter este quadro, pois no período de 2002 a 2004, significou para as zonas "maquiladoras" perdas de $21 \%$ do total de empregos e $1 / 3$ dos investimentos diretos estrangeiros.

Na China, a média dos investimentos diretos estrangeiros (IDE), mais do que dobrou a cada ano, pois passou de US\$ 2,5 bilhões na segunda metade da década de 80 do século passado para US\$ 64 bilhões em 2004. ${ }^{29}$ As leis trabalhistas que poderiam assegurar os direitos fundamentais aos trabalhadores são aviltadas pela ação sinistra das transnacionais em conluio com a elite orgânica local, precarizando as relações de trabalho e a seqüela que produz nas relações sociais e ambientais, pois as revoltas no meio trabalhista pretendem somente resguardar os direitos fundamentais de associação e negociação do Contrato Coletivo de Trabalho digno do caráter inteligível do ser humano.

ocorreria a mudança para a ainda utópica "Cosmocracia". Palavras chaves: harmonia, equilíbrio e compreensão.

${ }^{29}$ World Investment Report from United Nations (UN), 2005. 


\section{DESEMPREGO EM AGOSTO/2004 Milhões de Pessoas}

\begin{tabular}{|l|c|}
\hline REGĨ̃O & \% \\
\hline Tijuana & $\mathbf{0 . 9 2 \%}$ \\
\hline Cancun & $\mathbf{1 . 1 4 \%}$ \\
\hline Acapulco & $\mathbf{1 . 3 9 \%}$ \\
\hline Tampico & $\mathbf{1 . 5 4 \%}$ \\
\hline Campeche & $\mathbf{1 . 6 8 \%}$ \\
\hline Queretaro & $\mathbf{4 . 5 9 \%}$ \\
\hline Aguascalientes & $\mathbf{4 . 9 4 \%}$ \\
\hline Toluca & $\mathbf{5 . 4 8 \%}$ \\
\hline Saltillo & $\mathbf{5 . 5 6 \%}$ \\
\hline Ciudad México (Distrito Federal) & $\mathbf{5 . 7 8 \%}$ \\
\hline
\end{tabular}

Taxa de Desemprego Aberto (TDA)

Milhões de Pessoas

MÉXICO

\section{Tiiuana}

Cancun

Acapulco

Tampico

Campeche

\section{$3,96 \%$}

1.644 .021

2003

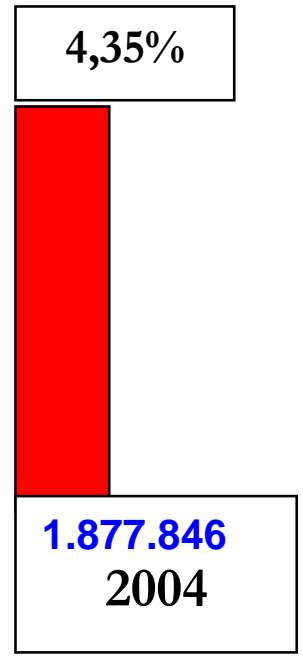

Oueretaro

Aguascalientes

Toluca

Saltillo

Ciudad de Mexico

Fonte: Instituto Nacional de Geografia Estatística e Informática (INEGI). Agosto de 2004. 
A região metropolitana da cidade do México foi a que mais contribuiu para a taxa de desemprego aberta, pois foi $1.43 \%$ superior que a média nacional de $4.35 \%$. A região metropolitana da cidade do México representa $42 \%$ da população economicamente ativa (PEA), o que daria cerca de 17.000 .000 (dezessete milhões) de trabalhadores. $\mathrm{O}$ subemprego situa-se em torno de 39\%, acima da média geral de $35 \%$ dos países da $\mathrm{OCDE}^{30}$ com um diferencial de gênero feminino de 59\%, ou seja, $24 \%$ acima da média geral. Esta foi a pior época desde 1997, sinalizando que a situação tende a piorar, pois a taxa média de desemprego em 2001 era de $2.4 \%$, segundo INEGI.

MÉXICO: Produtividade, Salário Real e Empregos

$$
(1980=100)
$$

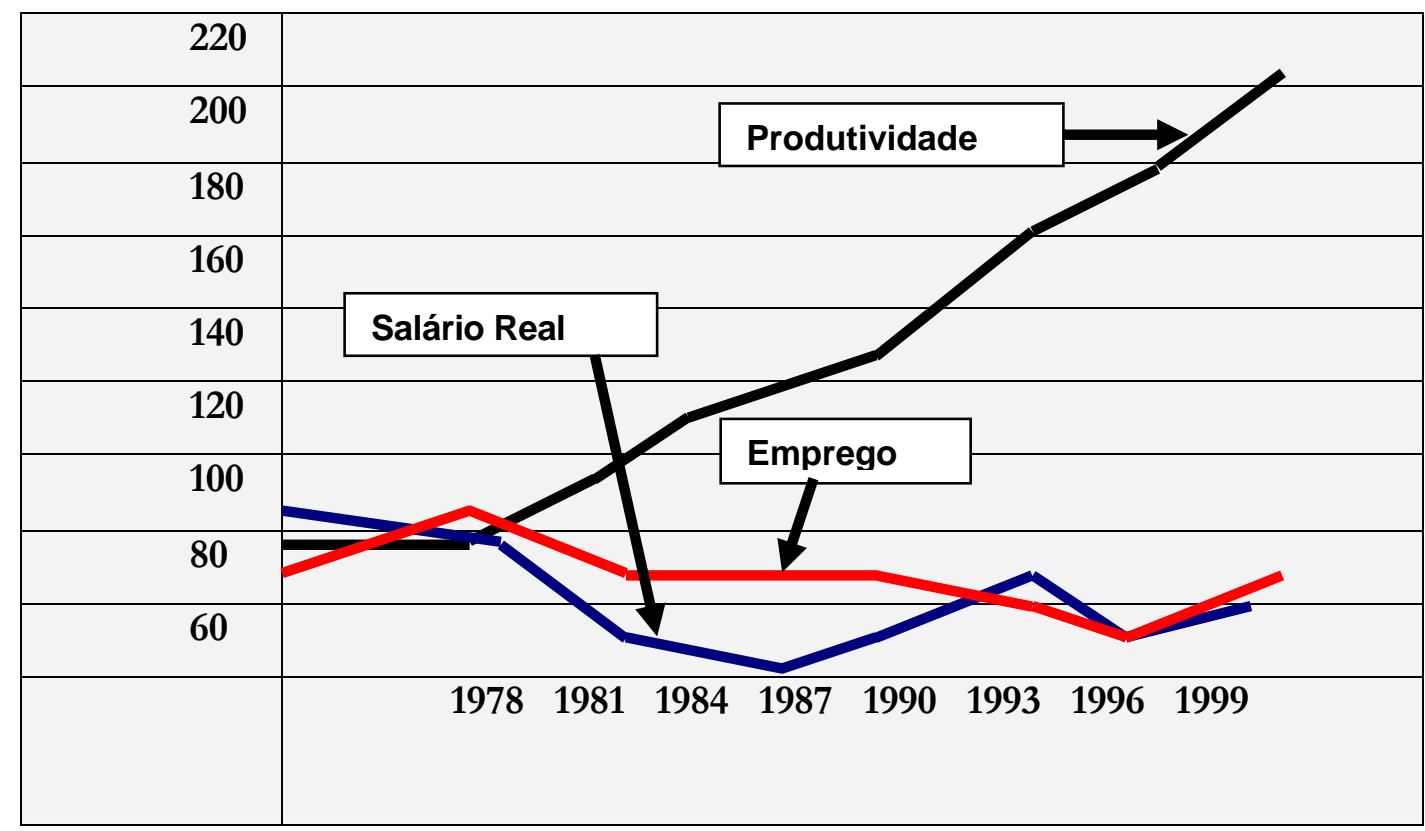

Fonte: Instituto Nacional de Geografia Estatística e Informática (INEGI). Banco do México. Terceiro Seminário sobre Rendas e Produtividade do NAFTA. Commission for Labor Cooperation, 2000.

Quando entrou em vigor o Acordo de Livre Comércio da América do Norte, que incluiu a adesão de México e Canadá aos Estados Unidos, em voga a partir de 1994, os investimentos diretos cresceram, mas aqui aconteceu exatamente o que tem acontecido em todos os lugares onde o sistema neoliberal tem atuado, inclusive nos Estados Unidos, ou seja, a produtividade tem crescido bastante, mas os salários crescem pouco,

\footnotetext{
${ }^{30}$ Organização de Cooperação e Desenvolvimento Econômico. OCDE - Employment Outlook, OECD, Paris, 2005.
} 
estabilizam-se ou decrescem. O argumento clássico de que o aumento da informalidade deve-se à baixa produtividade, que poderia estar relacionada à menor capacidade financeira, tem sido pouco consistente na atual conjuntura, pois a financeirização dos bancos privatizados têm domínio e controle dos ativos financeiros mais de acordo com os interesses rentistas.

A diferença é que nos Estados Unidos a situação do desemprego (destruição de 766.030 empregos entre 1994 e 2000) tem sido resolvida com os instrumentos de uma economia planejada e avançada, mas no México e Brasil as taxas recentes de desemprego têm sido crescentes, concomitantemente, à criação de empregos com taxas decrescentes. Nos EUA, o desnível entre produtividade e crescimento salarial é bem menor que no Brasil e México. O que se tem procurado afirmar é que a situação social dos trabalhadores, ao longo dos anos, vem se tornando cada vez mais precária em detrimento de uma acumulação indescritível de capital das corporações. 


\subsection{Sindicalismo no Brasil}

O Contrato Coletivo de Trabalho foi infundido a se reinstalar no país (1975/1984) pelo próprio processo histórico que nos tem sido imposto desde há muito tempo e devido, principalmente, aos interesses econômicos externos predominantes e que apropriadamente manipulados têm conseguido atitudes comportamentais que favorecem ideais de conduta que servem de guias na ação humana e, hoje, reforçada pelo padrão neoliberal, tem atuado sempre de forma a desviar a influência do Estado Nacional nas atribuições ligadas ao social para reforçar as de mercado cujas seqüelas, quando não devidamente orientadas, têm sido a falta de genuinidade e de uma menor dinâmica no desenvolvimento econômico do país, que pode ser traduzido por:

- $\quad$ falta da criação de empregos;

- $\quad$ desemprego causado por tecnologias importadas e não adequadas;

- $\quad$ excessivo aumento da lucratividade corporativa multinacional;

- $\quad$ desmonte da organização sindical;

- crescimento da má distribuição de riquezas sob o domínio de uma elite bem relacionada à elite orgânica transnacional, extraindo deste processo riquezas desequilibrantes que contribuem ainda mais para a deterioração da já péssima distribuição de rendas, e que acabam criando todo tipo de tensão econômica, social e política cujas soluções de harmonização vão-se tornando progressivamente mais difíceis.

Desta maneira no Brasil, a partir dos anos 80 do século passado, a tendência do econômico prevalecer sobre o político tem tido preponderância nas políticas externas dos países capitalistas, pois é esta a relação estratégica que favorece os interesses hegemônicos de dominação econômica que se traduz com as inferências da política neoliberal intervencionista que, de forma indelével, a todos tem constrangido.

O Contrato Coletivo de Trabalho vem sendo inculcado, estrategicamente, nas relações trabalhistas dos países que detêm os diversificados interesses comerciais das empresas multinacionais, como modelo tradicional dos países já detentores de tal 
especificidade em suas relações de trabalho, como forma de assegurar o bom andamento dos negócios sem interferências indevidas, ou seja, demasiada particularização, rigor e imperatividade de uma legislação do trabalho que procura atender o hipossuficiente, e da interposição do poder normativo da Justiça do Trabalho nos conflitos econômicos, que vinha descaracterizando, segundo aquela visão, sua função judicial em função da especificidade do fato econômico em si que não demanda determinações legais na sua construção, mas de fatores específicos de produção de mercado na sua relação com a divisão internacional do trabalho.

O que se tem verificado, de fato, em tal relacionamento, é uma precarização dos agentes em função da falta de uma regra mais bem definida que norteasse as nossas atitudes como país demasiadamente influenciado por idéias que não as suas próprias, como sói acontecer quando o espírito de colonizado ainda paira indelével no fundo do subconsciente. Nestas circunstâncias, observa-se um modo artificial de ser, e que é caracterizado por um intelectualismo extremado que identifica a frustração que a situação de dependência permeia na mente dos menos esclarecidos.

A propósito, esse poder normativo vem sendo cada vez menos utilizado nas soluções dos conflitos trabalhistas, fruto de uma influência engenhosamente orquestrada, eis que gradativamente substituído pela negociação coletiva, segundo padrão desenvolvido na Inglaterra, aperfeiçoada nos EUA; pois a interação jurídico-econômica deveria ser feita, teoricamente, no âmbito dos interesses mútuos, a econômica que ofereça à empresa as condições que garantam a manutenção e a criação de empregos e a jurídica que dê respaldo aos menos favorecidos. Tais variáveis estão constantemente em mudança, ocasionando uma situação caótica em que o imprevisível se encontra em toda parte e os mais conscientes são os que conseguem identificar pequenas mudanças que advirão em grandes transmutações, nem sempre de acordo com o projeto nacional, se no início de tal processo não forem identificadas para que se sejam tomadas as devidas precauções. Entre outras, a falta de desenvolvimento com crescimento econômico para as empresas genuinamente nacionais e a falta de condições que pudessem garantir um melhor desempenho da Justiça Trabalhista na defesa dos trabalhadores.

Durante as gestões do ex-presidente da República, Fernando Henrique Cardoso, foram introduzidas várias modificações flexibilizantes na legislação trabalhista, entre elas: 
- $\quad$ Banco de horas

- Contratação a tempo parcial

- Suspensão do contrato de trabalho para a qualificação profissional

- $\quad$ Contrato de trabalho por tempo determinado

- $\quad$ Participação dos trabalhadores nos lucros e resultados das empresas.Lei 10.101

- Instituição das comissões de conciliação prévia. Lei 9958, 12/jan/2000

Agora surge este projeto de lei 5483/01, complementada pela lei 9307/96 que na área trabalhista tem flexibilizado e descentralizado as relações de trabalho ainda que um estudo da OIT (2000) alerte sobre prejuízos da flexibilização do mercado aos trabalhadores da construção civil para cerca de 120 milhões de trabalhadores do setor no mundo, mas mesmo antes da tal lei já se encontra, no Brasil, totalmente flexibilizado e precarizado por conter trabalhadores oriundos das zonas mais pobres do país e destarte sem condições adequadas de uma autêntica representação para uma efetiva negociação coletiva.

Os custos trabalhistas muito elevados dos trabalhadores, mais especificamente desse setor, variam de $90 \%$ a $180 \%$ de seu salário e os investidores desse capital, não só em maior escala na área da construção civil, mas também em outras áreas, não têm regularizado suas respectivas carteiras de trabalho, negando-lhes o registro que os qualificariam a todos os benefícios da Seguridade Social. Dada a precariedade fiscal institucional, a situação degrada-se paulatinamente, e desvanecem-se as perspectivas de solução para este problema tão crucial. Em 1999, no Brasil, apenas 20\% dos trabalhadores estavam registrados, enquanto que nos anos 80 a proporção era de $40 \%$, e para piorar, a OIT (Organização Internacional do Trabalho) lembra que o número de operários passou de $2 \%$ da mão-de-obra do país para 4,4\%, totalizando 4,7 milhões de pessoas.

Além disso, a aludida lei 9307 sobre arbitragem e mediação, de 23.09.1996, também conhecida como lei Marco Maciel, reduziu a um mínimo a intercessão do Poder Judicial, aferindo à sentença arbitral igual competência à do juiz estatal, conforme artigo 31: "A sentença arbitral produz, entre as partes e seus sucessores, os mesmos efeitos da sentença proferida pelos órgãos do Poder Judiciário e, sendo condenatória, constitui título executivo". Verifica-se que tal apreciação de arbitragem não é novidade alguma, pois que prevista desde a promulgação da CLT em $1^{\mathrm{o}}$ de maio de 1943, no artigo $764 \S 2^{\mathrm{o}}$ : “Os dissídios individuais ou coletivos submetidos à apreciação da Justiça do Trabalho 
serão sempre sujeitas à conciliação. $\S 2^{\circ}$ Não havendo acordo, o juízo conciliatório converter-se-á obrigatoriamente em arbitral, proferindo-se a decisão na forma prescrita neste título".

$\mathrm{Na}$ análise do problema, sob a ótica específica do Contrato Coletivo de Trabalho, observa-se ênfase nas questões que demandem celeridade quanto aos aspectos econômicos do processo, evidenciando uma forte influência da política neoliberal, cujos interesses não se coadunam com os tradicionais direitos dos trabalhadores e segue a lógica acumulativa das grandes corporações transnacionais. Autoridades diplomáticas ligadas à área de trabalho (Labor Attachés), e que à época transitavam por aqui, referiam-se ao sistema jurídico brasileiro como arcaico e ineficiente, cujas sentenças trabalhistas levavam em média 8 anos para tramitarem em julgado.

A crítica sutil de tais autoridades subentendia não uma preocupação autêntica quanto ao bem-estar do trabalhador, mas ao próprio Poder Judiciário ainda capaz de interferir nos grandes interesses corporativos. A voluntariedade arbitral de que trata a referida lei sinaliza que o Judiciário vem sendo, paulatinamente, privatizado em detrimento da real defesa judicial já dotada, de mecanismos apropriados para o exercício do poder normativo da justiça do trabalho, tão bem alicerçados na tradição secular da difícil luta em favor dos trabalhadores, com ênfase nos hipossuficientes, como dita o espírito do próprio Direito Trabalhista.

Apesar de esforços para deslindar o sistema jurídico e alijá-lo de todo o conservadorismo que ainda o tem impregnado, pois não se coaduna com a dinâmica econômica global, uma vez que as normas jurídicas (que deveriam estar em constante mutação, seguindo mais de perto o maior dinamismo da economia capitalista sob a égide neoliberal) não se apresentam de maneira explícita na construção daquilo que constitui a razão própria do direito do trabalho, ou seja, com base em fundamentos provenientes de estudos filosóficos sobre a moral e a ética.

Em março de 1996, foi promovido pelo Superior Tribunal de Justiça um painel de debates sobre soluções alternativas de controvérsias que tratara do tema "Perspectivas 'brasileiras' no campo da solução alternativa de conflitos" que contara com o apoio integral das grandes corporações norte-americanas representadas pela sua Embaixada em Brasília. Seis meses depois foi promulgada a lei Marco Maciel denotando forte influência 
do conceito valorativo de Harvard, como pertinaz e dominante, em detrimento do mesmo conceito em Bernard Mayer $^{31}$ que impõe o valor como mais um elemento na disputa.

O sistema neoliberal preceitua que o "financeiroleconômicolprivado" deva prevalecer sobre o "políticolsocial\coletivo"; e o direito, essencialmente político, tem sido contrário às regras flexibilizantes que possam deturpar a conduta ilibada que o verdadeiro direito do trabalho tem o dever de assegurar aos trabalhadores, em especial aos menos favorecidos.

PROJETO DE LEI N 5.483, DE 2001.

Altera o dispositivo da Consolidação das Leis do Trabalho, aprovada pelo Decreto-Lei $n^{\circ} 5.452$, de $1^{\circ}$ de maio de 1943.

O CONGRESSO NACIONAL decreta:

Art. $1^{\circ}$. - O art. 618 da Consolidação das Leis do Trabalho, aprovada pelo Decreto-Lei no 5.452, de 1o de maio de 1943, passa a vigorar com a seguinte redação:

“Art. 618. As condições de trabalho ajustadas mediante convenção ou acordo coletivo prevalecem sobre o disposto em lei, desde que não contrariem a Constituição Federal e as normas de segurança e saúde do trabalho".

Art. $2^{\circ}$. - Esta Lei entra em vigor na data de sua publicação.

Enfatizando a disposição dos agentes já devidamente condicionados pela lógica neoliberal em disponibilizar conteúdo tipo: "no campo das relações trabalhistas, a disposição sobre direitos negociáveis deverá ser feita por quem as desejam e considerem mais vantajoso entabular uma negociação ou seja, serão os próprios interessados que de comum acordo, deliberarão se o direito legislado deverá prevalecer ou não", ou ainda: "o tipo de negociação coletiva apregoada na presente sugestão preserva os direitos mínimos dos trabalhadores previstos na Constituição Federal, as normas de segurança, higiene e saúde do trabalho". Estas declarações têm demonstrado que pessoas não devidamente

${ }^{31}$ MAYER, Bernard. The Dynamics of Conflict Resolution: a Practioner's Guide. San Francisco: Editor Jossey Bass, 2000, p. 140-212. 
qualificadas, mal preparadas e intencionadas têm contribuído na condução dos destinos da nação para aqueles efeitos perversos que advêm de modelos impostos de outras culturas, não devidamente adaptados, pois que apesar de todo este apregoamento falta-lhes a sustentabilidade que caracterizam modelos autênticos. Para poucos setores da produção esta relação tem sido proveitosa, mas para a grande maioria de trabalhadores os resultados não são animadores, pois carece de um processo formativo que envolva aspectos essenciais para uma melhor caracterização de sua identidade cidadã.

Não só a condição muito conservadora da CLT, bem como o excesso de tributos tem desestimulado a criação de novos empregos e a inclusão efetiva do trabalhador com seus direitos assegurados no mercado de trabalho.

O equilíbrio é a função que efetivamente regula a harmonia do poder nas relações trabalhistas, não só da lei trabalhista protetora em si mesma, mas da presença de sindicatos independentes, dinâmicos e autênticos. A lei trabalhista sem sindicatos livres, não protege o trabalhador como também não deslinda o poder do empregador. Os dispositivos da Convenção $\mathrm{n}^{\circ}$ 98, da OIT, de 1949, identificam perfeitamente tais preocupações.

O fato da função do Estado, quanto ao reconhecimento e a atuação como árbitro neutro, de assegurar o direito de associação sindical livre e amparo contra o excessivo poder econômico e influência política indevida são metas que identificam sua conscientização social do devir que a ação humana soberana poderá desempenhar no amparo às futuras gerações.

Melhor do que o desenvolvimento de uma nova ferramenta, mormente, imposta de maneira indevida por grandes interesses ligados ao capital hegemônico e, destarte, não adequados ao país receptor, é o aprimoramento reformista próprio de nossas instituições trabalhistas já consolidadas e aptas às reformulações necessárias quando efetivadas de acordo com nossas características, que irão permitir um melhor entendimento das relações de trabalho específicas desta ou daquela sociedade.

A construção de uma reforma no sistema de relações do trabalho que ajude definitivamente a fazer das relações trabalhistas não um simples jogo, mas uma estratégia que contribua para o incremento dessas relações, tendo como prioridade o conjunto dos interesses da sociedade. Deve-se reformar e não se deixar iludir pelas manipulações que 
caracterizam as políticas hegemônicas de dominação com a arregimentação de uma elite submissa e muito comprometida com seus próprios interesses.

O equilíbrio regulador de harmonia de poder nas relações trabalhistas parece ser o fator fundamental para que seja exercida a "Cosmocracia". Como é clara a opção pelo reformismo, o "estado regulador" deverá deliberar de acordo com permanente consulta de órgãos competentes, como os sindicatos entre outros, que mais e mais ganharão poder decisório quanto mais integrados estiverem no planejamento estatal da política econômica.

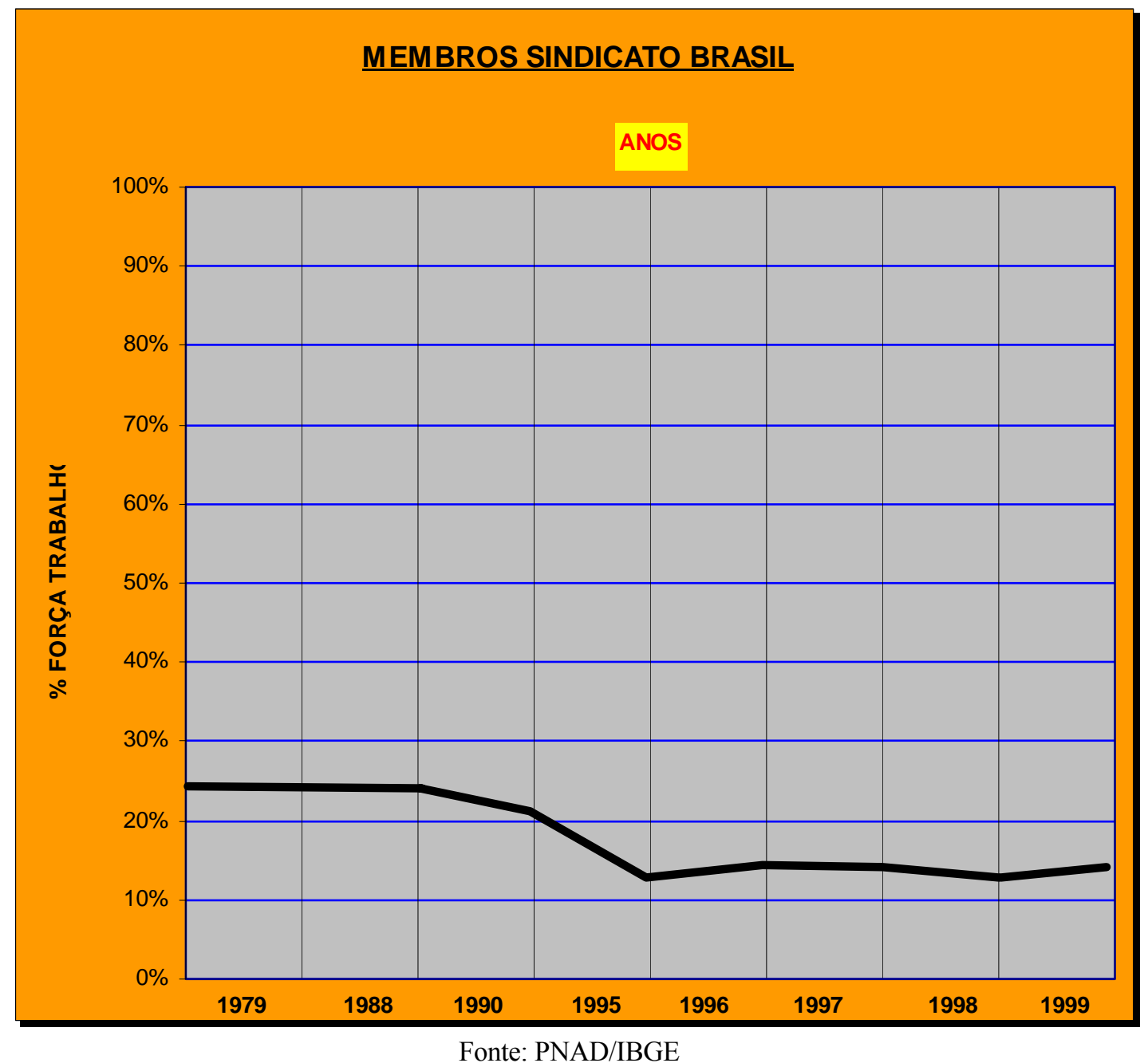

Conforme está mostrada graficamente acima, em 1999, a porcentagem da força de trabalho sindicalizada no Brasil era de 15\%, quando, em 1979, era de 22.5\%. Pelo que se observa neste gráfico, infere-se que, a força dos sindicatos não era muito vigorosa à época, vinte anos atrás, e acompanha a tendência mundial de decrescer cada vez mais. 
Estudos da densidade sindical no Brasil realizados alhures indicam densidade média em torno de $40 \%$ a $45 \%$, pois levam em consideração a obrigatoriedade que caracteriza a sindicalização brasileira com a instituição do imposto sindical, mas que não refletem, de fato, a sindicalização propriamente dita. Estes números são conseqüências, entre outras descritas na conclusão do presente trabalho, de basicamente três limitações das atividades sindicais, ou seja:

1) As restrições institucionais já descritas.

2) Reestruturação produtiva, novas tecnologias, interatividade internacional megacorporativa. Essas mudanças nos últimos vinte anos na economia brasileira têm resultado numa estrutura de mercado mais aberta, mais competitiva e inserida na globalização neoliberal que tem resultado numa maior precarização nas relações trabalhistas pelo simples motivo de não ter maior autenticidade, mas derivadas de economias capitalistas bem consolidadas.

3) A existência de um grande setor informal crescente, conseqüência desta derivação, sendo que proceder à organização tem sido uma tarefa muito árdua para os sindicatos de trabalhadores que se preocupam com este aspecto perverso do sistema.

\section{EMPREGO, PRODUÇAO E PRODUTIVIDADE INDUSTRIA} $1985=100$

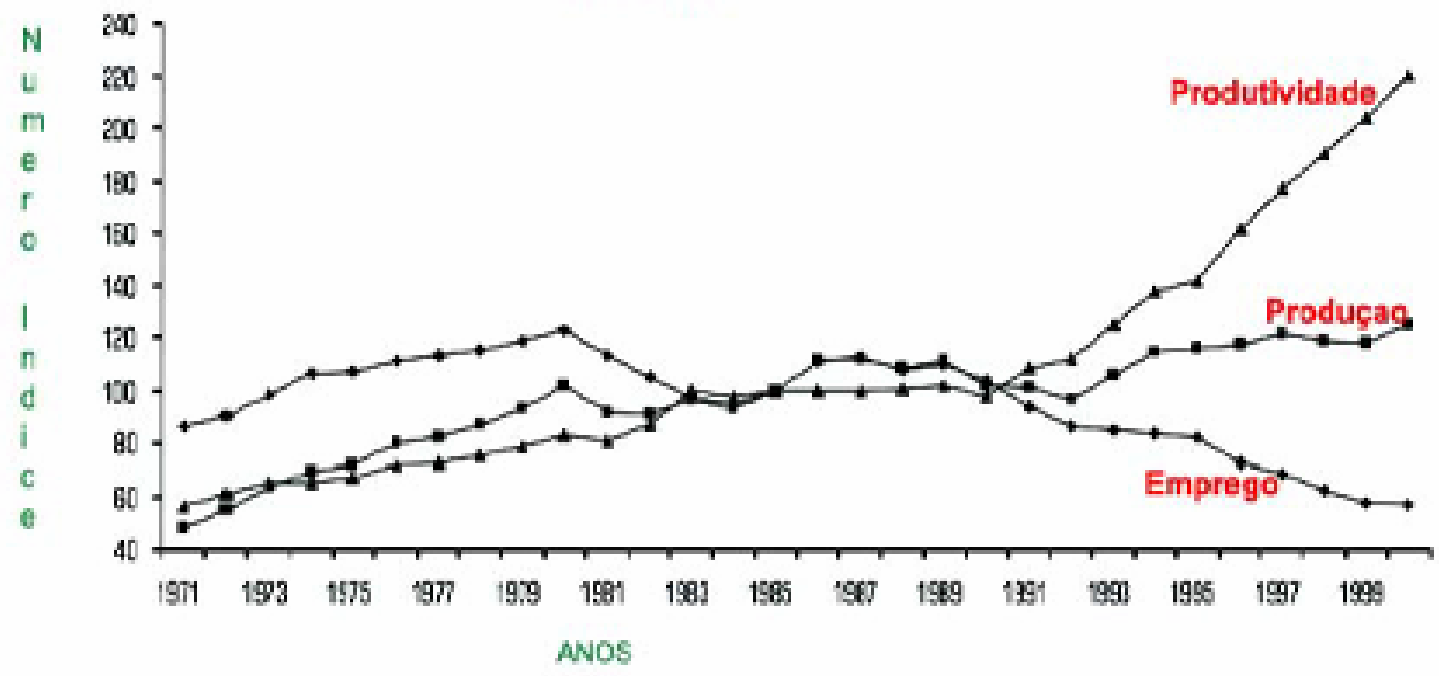

Fonte: Instituto Brasileiro de Geografia e Estatistica (IBGE) Pesquisa Mensal. 
Foi a partir de 1990 que a produtividade apresentou um crescimento desproporcional em relação à produção e a diminuição da criação de empregos que, coincidentemente, tem sido conseqüência do efeito neoliberal em que a globalização traz em seus desdobramentos mais aparentes a precarização do emprego, o desemprego e as formas inéditas de organização do trabalho. Os efeitos perniciosos das propostas neoliberais trazem no bojo da sua configuração o aumento do desemprego no âmbito da produção, inicialmente para os paises periféricos dependentes e finalmente para os próprios países detentores hegemônicos de capital e tecnologia. $\mathrm{O}$ atrelamento da produtividade ao salário decai conforme as perspectivas do mercado global, primeiro nas economias menos desenvolvidas, para em seguida, atingir as próprias economias mais desenvolvidas.

A produtividade do capital oscila da estabilidade ao crescimento sem controle, evidenciando a falta de políticas públicas autênticas direcionadas ao crescimento do emprego e do bem-estar social do trabalhador com salários reais crescentes, com isso a taxa bruta de lucro das corporações têm crescido de maneira desproporcional a favor da acumulação exagerada que, em contrapartida, não tem gerado os respectivos investimentos, enfraquecendo o desempenho econômico, e os sindicatos e fortalecendo o desemprego estrutural.

Os sociólogos explicam que as formas rígidas de produção no modelo fordista, expresso pela produção uniforme em série, com hierarquia austera e inflexível, fundem-se com o modelo toyotista japonês mais flexível e já bem amoldado à produção globalizada, com o uso de recursos da tecnologia de informação e automação. O resultado da importação destes modelos tem sido a precarização do trabalho e desemprego estrutural crescente, sempre frutos da falta de crescimento econômico, que numa análise mais ampla, conduz-nos à inexorável força do capital, que está sendo deformada em atitudes inovadoras por aqueles que já têm a hegemonia do poder e que dependem quase que exclusivamente de suas aptidões intelectuais, mas não atentam às circunstâncias que distinguem as pessoas, graças às quais é possível individualizá-las quanto ao objeto das ciências humanas, do processo cognoscitivo que em vez de analisar as causas primárias esmiúçam os efeitos secundários num formidável espetáculo que maquila a verdadeira face da realidade. A importação de modelos e equipamentos favorece para quem produz 
tais tecnologias com o crescimento do emprego e no índice de desenvolvimento pessoal, mas não para quem as apropria de maneira inadequada ou imprópria.

O conjunto das mudanças institucionais, que tem provocado a redução dos investimentos com o crescimento da taxa real de juros, resultando no aumento da nossa dívida externa, repercutiram na área trabalhista com a falta de elementos que pudessem propiciar a criação de empregos. Observe-se que não podemos falar de criação de empregos e o progresso de suas relações, sem levar em consideração estes aspectos macroeconômicos. Com isso o acúmulo de capital para investimentos diretos nos anos 90 continuou com taxas reduzidas de crescimento em níveis similares aos verificados nos anos 80, pois apesar de haver um maior dinamismo na transferência tecnológica para países de industrialização secundária, o que significa menor desembolso para $\mathrm{o}$ financiamento de capital humano próprio, essencial para um desenvolvimento econômico que ofereça suporte a um crescimento mais autônomo.

Os efeitos da terceira revolução industrial têm evidenciado que a velha retórica clássico-econômica, de que se se aumenta a produtividade, as pessoas trabalharão menos e de maneira mais eficiente, pois a caída inicial da remuneração seria superada pelo grande aumento na produtividade, tem-se revelado falaz quanto ao aumento real de salário e na criação de empregos. $\mathrm{O}$ efeito é temporizado de acordo com a conjuntura econômica globalizada: num primeiro momento atinge as economias de industrialização secundária para, no próximo momento atingir as próprias economias de industrialização primária. O que tinha sido válido na era da primeira e segunda revolução industrial, com os instrumentos econômicos clássicos, neoclássicos e keynesianos, na era pós-industrial o enfoque deve-se voltar principalmente ao olhar crítico de nós mesmos e encarar os diversos desafios que se nos apresentam, para a análise econômica e implementação de políticas mais adequadas. Há necessidade de um novo sistema político-econômico que condiga com a realidade global e que tenha os atributos sociais voltados ao nosso destino como seres humanos e não como meros objetos de uma teoria de jogos, em que a humanidade não vem sendo devidamente considerada e cuja situação está, inexorável e paulatinamente, levando-nos a uma insustentabilidade global crescente.

Contemporaneamente, o acréscimo da produtividade tem possibilitado pequenos aumentos do salário real somente a uma pequena parcela de empregados privilegiados das grandes indústrias mais dinâmicas onde se destaca o setor automobilístico, como fonte de 
inovações na estrutura da produção capitalista. Nestas, os sindicatos são mais estruturados, mas sob o sistema neoliberal tais custos do trabalho estão gradativamente sendo minimizados para serem acrescidos aos lucros corporativos numa atitude antisindical preocupante.

De 1991 a 1998, a taxa agregada de produtividade no Brasil foi de $2.53 \%$ ao ano, destacando-se a indústria automobilística que cresceu $9.4 \%$ ao ano. ${ }^{32}$ Os empregados das grandes indústrias no Estado de São Paulo tiveram um aumento real de 8,6\% nos seus salários desde o começo do plano real (Instituto de Estudos para o Desenvolvimento Industrial, Carta IEDI, n. 146, 2004).

Segundo dados do Departamento Intersindical de Estatística e Estudos SócioEconômicos (DIEESE-Anuário 2000) o total de empregados, nas montadoras na região metropolitana de São Paulo, em 1990 era de 57.939 e no ano 2000 reduziu-se para 33.877, ou seja, o total de empregados nas montadoras, nesse ano era bem menor que o total de uma só montadora em $1979 .{ }^{33}$

Nos EUA, a redução na indústria automobilística foi ainda mais radical, pois em quatro anos, de 1978 a 1982, foram destruídos cerca de 450.000 empregos que foram transferidos para outros locais, preferencialmente, aonde os direitos trabalhistas não são, devidamente, observados e de mão-de-obra barata. Em ambos os casos, o já forte sindicato de trabalhadores ou o fortalecimento deste, as novas tecnologias eletrônicas e robóticas aliada à nova estrutura organizacional transnacionalizada, tem ocasionado nos EUA a destruição de empregos e a criação destes em outros setores, mas, em outros países do capitalismo secundário, destruição com pouca ou nenhuma criação de empregos. A precarização relativa das relações de trabalho em ambos casos tem sido uma resultante sempre ruim para os trabalhadores estadunidenses; evidentemente, bem mais grave para os trabalhadores dos países latino-americanos dependentes.

Faz 45 anos, desde a instalação da indústria automobilística no Brasil, facilitada pelo Plano de Metas do então presidente da república, o médico-cirurgião Juscelino Kubitschek (1956 a 1961); até 1980 essas indústrias criaram diversos empregos, tendo

\footnotetext{
${ }^{32}$ BONELLI, R. e FONSECA, R. Ganhos de produtividade e eficiência: resultados novos da economia brasileira. Texto 557. Rio de Janeiro: IPEA, 1998.

${ }^{33}$ A indústria automobilística da região do $\mathrm{ABC}$, na área metropolitana de São Paulo, é um exemplo prático da experiência profissional do autor desta tese que trabalhou no final dos anos 70 , na área de recursos humanos de uma grande montadora, quando esta contava com um contingente de aproximadamente 45.000 empregados.
} 
atingido o grau máximo de utilização do recurso produtivo com a mão-de-obra qualificada e semiqualificada devidamente empregada. Foi a partir do final dos anos $70 \mathrm{e}$ início dos anos 80 que o ponto de inflexão tornou-se mais evidente por uma série de fatos combinados que, ora nem sempre o foram devidamente divulgados, ora tampouco foram coerentemente bem interpretados. 


\section{C a pít t u lo I I I}

\section{EXPERIÊNCIA SINDICALISTA NOS ESTADOS UNIDOS}

A historiografia do trabalhismo norte-americano existe desde o final do século XIX, mas foi tratada com bastante indiferença até meados dos anos 50 do século XX quando floresceram os historiadores sociais que vêm desafiando a cultura, política e instituições dominantes.

Até 1910, os historiadores estadunidenses, membros da elite branca protestante, preocuparam-se quase que exclusivamente em relatar os feitos das autoridades governamentais, diplomáticas e militares. A partir daquele ano é que surgiram então os historiadores que programam passo-a-passo o rumo a um desenvolvimento de uma nova história mais conectada com as ainda incipientes ciências sociais, imprescindíveis para a formulação de políticas públicas, mas que não se desenvolveram do modo pelo qual seria conveniente, no sentido de assegurar uma maior valorização do ser humano e assim assegurar uma perspectiva de vida mais adequada aos trabalhadores.

A classe dominante tem arregimentado todas as forças disponíveis na expectativa de perpetuação de seus valores, mas o surgimento de uma nova classe de historiadores que se distinguia pelo engajamento nos valores progressistas com a libertação das restrições que a ignorância da realidade e dos fatores objetivos e subjetivos da cultura dominante pudesse-lhes condicionar a sua maneira progressiva de analisar os fatos. A partir deste importante marco, a nova história reformulou o passado norteamericano, delineando as perspectivas de uma nova direção que os levasse ao conhecimento da realidade daqueles que sempre estiveram à margem da história e, contudo, são os responsáveis pelo alicerce que vem caracterizando a sua economia: os trabalhadores.

Sob o signo das ciências humanas, a era progressista termina com o advento da Primeira Guerra Mundial após atingir o auge desde 1890. A partir desta Primeira Grande Guerra iríamos contemplar a década da "eficiência" imperiosa que, aliada a uma democracia incipiente preservou aspectos progressistas até meados da grande crise capitalista de 1920-1930. Aliás, o conceito de "progressivismo" está vinculado à 
criatividade distinta da classe média crente que se encontra aturdida com conflitos de valores morais e religiosos e a crescente competição capitalista, mas que não sabendo como, necessitava de um instrumento conciliador para uma nova reforma. O aparecimento dos economistas institucionais sublevara a economia clássica ortodoxa de mercado competitivo livre e das ações coletivas dos trabalhadores, que têm sido vistas como interferências indevidas no livre jogo de mercado que já não se coadunavam com a emergente industrialização de produção escalar. A procura de modelos abstratos para explicar o ambiente econômico conduziu-os às práticas metodológicas advindas da pesquisa histórica.

A negociação coletiva do trabalho nos Estados Unidos, tal qual conhecemos hoje, foi fruto das grandes mudanças sociais e econômicas que caracterizaram os anos 30 do "New Deal" do presidente Roosevelt, ${ }^{34}$ que devemos ter em mente para analisar de que maneira a influência deste instrumento tem repercutido na economia-política norteamericana. Mesmo com a elitista Suprema Corte norte-americana agindo contra as medidas reformadoras de Roosevelt, aquela granjeara a ratificação dos fundamentos da legislação trabalhista americana com a sanção da Lei Wagner (Wagner Act) e a Lei de Segurança Social (Social Security Act). A cultura foi moldada em termos de padrão de comportamento e valores nacionalistas que culminou em frases de estilo, a exemplo de " $\mathrm{O}$ sonho americano" (American Dream) ou "Ame-o ou Deixe-o" (Love it or Leave it) etc.

A estrutura Taylorista $^{35}$ propiciou relações empregatícias estáveis de longo prazo no mercado de trabalho interno.

Faz-se necessário mencionar aqui o aforismo que resume bem o ambiente teórico-econômico que prevalecia à época da depressão econômica ocorrida dos anos 20 do século passado:

"Let do, let pass: the world goes by itself".

"Deja hacer, deja pasar: el mundo camina por sí mismo".

Deixa fazer, deixa passar: o mundo anda por si mesmo.

"Laissez faire, laissez passer: le monde va de lui même".

\footnotetext{
${ }^{34}$ Franklin D. Roosevelt (1882-1945) conseguiu aprovar duas normas liberais em 1935 que são os alicerces da legislação trabalhista norte-americana: Lei Wagner e Lei de Segurança Social.

${ }^{35}$ In: TAYLOR, Frederick Winslow (1856-1915). Princípios de administração científica (1911); engenheiro tecnocrata norte-americano que formulou soluções racionais de maximização produtiva relegando aspectos humanos, sociais ou psicológicos; alienou a iniciativa, fantasia e inteligência do trabalhador.
} 
Esse aforismo liberal iluminista do século XVIII foi utilizado pela burguesia na sua luta contra o poder da igreja e da nobreza que tradicionalmente usufruíam os privilégios de classe. Desde então, entre 1920 e 1936, foram praticamente dois séculos, que culminaram com a mais grave crise do capitalismo na sua fase neoclássica marshalliana; ${ }^{36}$ a situação da análise teórica econômica fora a "lei de Say"37 que propugnava "a oferta cria sua própria demanda" e o "desemprego seria temporário, parcial e esporádico" e a "concorrência seria perfeita".

Após a quinta-feira negra da Bolsa de Valores de Nova Iorque (EUA), em outubro de 1929, desabou todo o arcabouço teórico em voga até então, pois o desempenho que já era adverso à expansão econômica e, primordialmente, o desemprego persistente desde 1920, fez a economia desandar de vez, causando graves reflexos sobre o mercado mundial, especialmente nos países que viviam em função da economia estadunidense. Surgia uma nova teoria para tentar explicar os sérios acontecimentos.

De um lado, os trabalhadores:

- Salários: o salário já não obedece à lei de procura e oferta de trabalho

- Sindicatos: o sindicalismo impede que os salários decresçam, desfazendo artificialmente o livre jogo de mercado.

De outro lado, as empresas:

- Monopólio: empresas do início do século XX afastaram-se do modelo de concorrência perfeita com o acúmulo desproporcional do estoque.

- Oligopólio: houve acordos empresariais para o domínio da maior parcela de mercado com controle de preços e, só que, a demanda neste caso não se efetivou por causa dos altos estoques, suficientes para atender à demanda várias vezes e, como refutara $\mathrm{Keynes}^{38}$, com a possibilidade real de insuficiência global da demanda para as novas sociedades industriais.

\footnotetext{
${ }^{36}$ MARSHALL, Alfred. (1842-1924) Principles of Economics (1890); escola marginalista inglesa.

${ }^{37}$ SAY, Jean-Baptiste (1767-1832). Traité d'économie politique (1803); princípio fundamental da economia ortodoxa até então.

${ }^{38}$ KEYNES, John Maynard. (1883-1946) The General Theory of Employment, Interest and Money (1936).
} 
Foi neste clima que surgia em 1936 a macroeconomia, ramo da ciência econômica, que com o keynesianismo e a respectiva sistematização teórica botou abaixo todos os conceitos da ortodoxia da Escola Marginalista, colocando o Estado num estreito relacionamento das atividades econômicas, desmistificando a existência do equilíbrio automático.

Nos anos dourados do capitalismo, no período seguinte à Segunda Guerra Mundial, e sob condições político-econômicas peculiares, a relação do capital versus trabalho intensificou os aspectos macroeconômicos do nível de emprego ascendente, as condições de saúde e higiene do trabalho e a posição vantajosa dos trabalhadores nas discussões sistemáticas dos Contratos Coletivos de Trabalho, demonstrando uma conciliação peculiar e exemplar do capital em questões trabalhistas e sociais.

Paralelamente, um acentuado desempenho nacionalista dos Estados em direção ao crescimento sustentado de suas economias, e as reformas keynesianas do bem-estar social e pleno emprego foram questões preferenciais dos compromissos nacionaisdesenvolvimentistas.

A estruturação do movimento trabalhista nos EUA nunca teve a mesma orientação, decisivamente, mais política que a do Brasil e México e de alguns países da Europa ocidental, pois as idéias socialistas foram infrutíferas desde que seu desenvolvimento capitalista, sem precedentes na história, fez da propriedade e sucesso particulares uma idolatria e que bem tem caracterizado a sua alienação das relações de classes dentro do sistema produtivo próprio, bem como nas suas relações com países menos desenvolvidos, retratando bem o problema clássico da Sociologia, segundo sublinhou Sombart. ${ }^{39}$

Desde os primórdios da industrialização, a força titânica do capitalismo norteamericano fez com que os sindicatos de trabalhadores confrontassem-se de maneira muito parcial com as tramóias capitalistas das empresas, como na troca das famosas "listas negras" em que os nomes de empregados partícipes de greves eram identificados com a finalidade de negar-lhes emprego. Naqueles Estados onde o desenvolvimento econômico era maior, com a respectiva interação das forças políticas, sempre foram sancionadas leis estaduais que restringiam as atividades sindicais, bem como o envio de tropas federais e milícias estaduais para terminar com as greves. A batalhas com que enfrentavam os

\footnotetext{
${ }^{39}$ Werner Sombart (1863-1941): economista alemão da Escola Histórica alemã. In: SOMBART, Werner. Pourquoi le Socialisme n'Existe-t-il pas aux États-Unis?. France-Paris: P.U.F., 1992.
} 
trabalhadores na luta por seus direitos, desde fura-greves até guardas particulares armados da famosa agência nacional de detetives Pinkerton, eram intensas. Essa agência contava, em 1890, com cerca de 2000 agentes efetivos, mais dezenas de milhares de agentes eventuais envolvidos nas mais diversas áreas, que faziam o papel de guardas armados e agentes secretos ao se infiltrarem nos movimentos operários para obter todas as informações necessárias para o contra-ataque das empresas. Tinham uma disciplina militar, adaptada para ser usada nos meios mercantis e dotada de um sistema de patrulha preventiva muito eficiente.

Agentes da Pinkerton

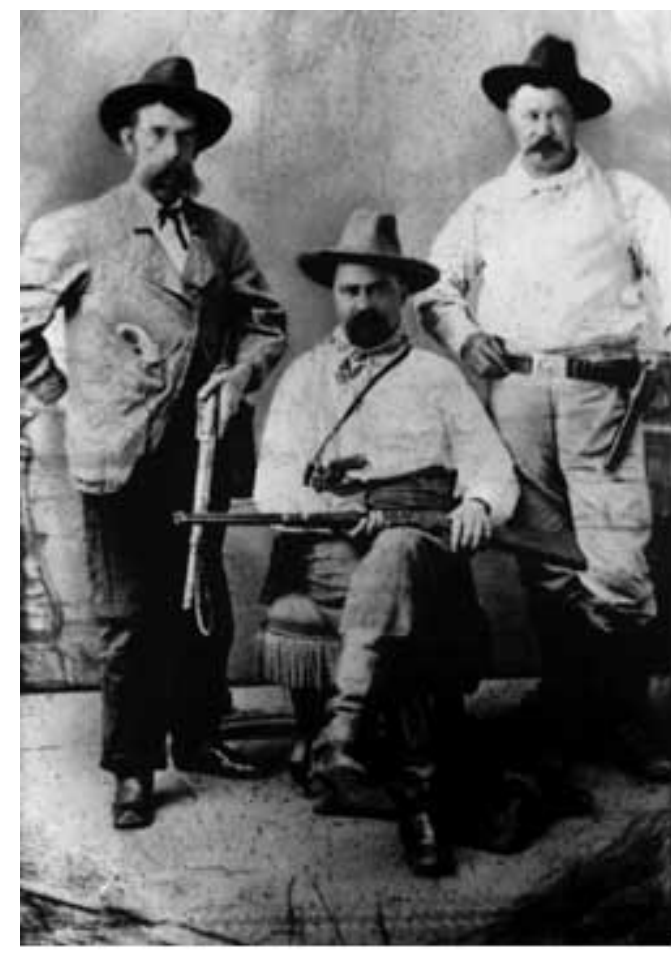

Fonte: The Library of Congress - The First Private Eye (O primeiro olhar privado); Agentes especiais da segurança ferroviária nos últimos anos de 1870. Disponível em http://www.loc.gov/loc/lcib/0006/pink.html. Acesso em Março de 2005.

Dadas as circunstâncias peculiares daquele momento histórico factual da industrialização e opressão aos trabalhadores dos sindicatos mais fortes, ligados aos produtos e serviços primordiais, tais como: carvão, ferro, madeira, vias férreas, estivadores e comércio; as patrulhas preventivas Pinkerton garantiam um serviço de qualidade ao identificarem movimentos paredistas, organizações secretas trabalhistas que 
pudessem ameaçar a propriedade e a estabilidade do negócio das empresas. Ameaças violentas sempre foram "ilegais", mas os tribunais têm se mostrados inócuos para punir as eventuais empresas que usassem de tal artifício para intimidar o trabalhador. Somente de 1935 a 1947, foram amenizadas as ameaças violentas explícitas, com a lei Wagner "Wagner Act" que pune a prática trabalhista injusta, ainda que, tornando-se mais sutis, implicitamente, não deixassem de ocorrer. Nestes quase 200 anos da história trabalhista norte-americana, os tribunais e o poder legislativo sempre tiveram uma posição antisindicato e a norma tem sido sempre a favor do empregador; aqueles partem do pressuposto de quem acumulou capital fez por merecê-lo, o que nem sempre é verdadeiro.

No final do século XIX, em plena depressão econômica, uma série de greves foi esmagada violentamente por tropas do governo e pelo movimento empresarial antigreve. O que chama a atenção foi a controvertida greve de 1894, a greve da Companhia de Vagões Ferroviários Pullman, que envolveu um total de 50.000 empregados entre trabalhadores da indústria Pullman, então integrantes do Sindicato dos Ferroviários Americanos (American Raiway Union - ARU) e dos próprios trabalhadores ferroviários das vias então pertencentes ao Sindicato dos Trabalhadores Ferroviários Americanos (American Railway Workers Union - ARWU) que lutaram contra as dispensas e cortes dos salários. A imagem do sindicato e seu poder foram enfraquecidos durante este período que poderíamos chamar de período anti-sindical.

Foi somente a partir de 1932, com a eleição do presidente Franklin Delano Roosevelt, que o movimento sindical começou a ser visto não como uma ameaça, mas como peça chave para o desenvolvimento e crescimento econômico. O "New Deal" de Roosevelt fortaleceu os sindicatos, regulamentou as condições de trabalho e salários, multiplicou as obras públicas para conter o desemprego e, após a sua reeleição, mesmo com a forte oposição da Corte Suprema, conseguiu a aprovação das leis: "Wagner Act" e "Social Security Act", que são os alicerces da legislação federal trabalhista norteamericana. Foi o início da época de concessões pró-sindicato, que perdurou até o fím da Segunda Guerra Mundial. Desde então, o período tem sido de relativo equilíbrio com tendências recentes pró-corporações.

A lei Wagner (Wagner Act) regulamentou a NLRA (National Labor Relation Act) através da NLRB (National Labor Relation Board) que é o instrumento principal dos CCT (Contratos Coletivos de Trabalho) na formação da Unidade de Barganha Coletiva 
(Bargaining Unit). A Unidade de Barganha é um grupo de trabalhadores nem sempre sindicalizados que, à custa do processo produtivo ou interesses comuns é eleita e determinada pela NLRB como representante daquela unidade de trabalhadores para a negociação do Contrato Coletivo de Trabalho. Neste propósito os mais eficientes são os delegados naturalmente mais competitivos.

De acordo com uma pesquisa realizada pela NLRB, cerca de 180 mil unidades de barganha coletiva foram selecionadas, em conformidade com os critérios de interesses comuns, destacando-se: os ganhos, benefícios, habilidade, interação, equivalência de funções, proximidade da função produtiva, entre outras.

Tais disposições nem sempre são integralmente aceitas, é quando a NLRB pode usar o instrumento democrático do voto secreto para assegurar a preferência majoritária dos empregados. Dependendo da estrutura organizacional da empresa, às vezes, com uma mesma supervisão para diferentes secções, as unidades podem ser concertadas, mas sempre devem ser resolvidas caso a caso, prevalecendo o histórico destas relações. Caso haja consenso entre a empresa e o sindicato, e sendo este consistente com as normas da NLRA, tal unidade de barganha coletiva poderá ser aceita pela NLRB com a denominação de "unidade ajustada" àquelas condições específicas. Entre os mais especializados, por exemplo, os torneiro-mecânicos ou ferramenteiros, tem ocorrido problemas de perdas quando a maioria naquela unidade não é especializada, problema clássico das negociações de contratos coletivos nos Estados Unidos, devido a heterogeneidade da composição dos trabalhadores daquela área nem sempre ajustada às especificações mais genéricas. Ocorre um rompimento por divergência de interesses e a decisão vai depender da tradição da empresa, do histórico de seus contratos coletivos, dimensão da homogeneidade e a probabilidade na quebra do contrato.

Para aqueles trabalhadores mais especializados que envolvem trabalho mais intelectual e diverso, com prática de apreciação mais independente e requerendo estudos mais avançados e especializados, a NLRA (Section 2, 12) oferece a opção de escolha, permanecer no grupo ou separar-se, podendo tal ato ser definido quando da emissão do certificado daquela unidade de barganha pela NLRB.

Para todo pessoal de segurança das firmas, por uma questão de bom senso, pois envolve conflito de interesses durante uma greve, não podem ser representados na mesma 
unidade de barganha dos outros empregados. O pessoal de segurança precisa ser representado por um outro sindicato, conforme normas da NLRA (Section 9, b, 3).

Por causa dos grandes conflitos de interesses e do próprio sentido do direito à livre agremiação: supervisores, gerentes e cargos de confiança não têm seus direitos garantidos pelas emendas da lei Taft-Hardley que revisionou a NLRA (WagnerAct), regulamentada e supervisionada, pela NLRB. Eles têm negociado direta e individualmente, caso a caso, com a cúpula da firma.

Então, os supervisores não podem ser representados pelo sindicato, pois suas atribuições conferem a eles domínio sobre os empregados (NLRA: Section 2, 11) nos seguintes quesitos:

- Empregar ou despedir,

- Transferir ou suspender,

- Atribuir funções,

- Revogar ou promover,

- Gratificar e

- Disciplinar.

Os gerentes, na grande maioria dos casos, formam uma comunhão entre os executivos de uma firma, responsáveis pela política administrativa que atende às resoluções do proprietário ou da assembléia geral dos acionistas.

Os cargos de confiança que têm acesso às informações confidenciais financeiras e da secção pessoal, também não podem participar daquela unidade de barganha.

Serviços prestados por empreitada são também excluídos das unidades de barganha, pois o empreiteiro controla o preço, bem como o trabalho que será prestado, a contratação de outros empregados e a compra de materiais, uma vez que a sua renda, através de seus lucros, é que irá renumerar os fatores. Caso haja pagamento de salário sem a intermediação na compra de materiais, pelo empreiteiro, o caso poderá ser incluído na unidade de barganha.

Os empregados temporários regulares tendo cumprido pelo menos $1 / 6$ dos dias estipulados para aquela tarefa com expectativa de recontrato são incluídos na unidade de barganha, assim como os empregados de meio-período que compartilham os mesmos 
interesses dos demais. Os empregados temporários esporádicos, sem expectativa de recontrato, são omitidos daquela unidade de barganha.

Motivo de grandes contradições têm sido as aquisições e fusões de empresas que formam grandes conglomerados quanto à situação dos acordos coletivos precedentes no sentido de assegurar os direitos trabalhistas aos empregados. $\mathrm{O}$ empregado sucedido não se obriga aos acordos firmados pelo antecessor da mesma forma que ao empresário sucessor não está prescrita a obrigatoriedade de empregar trabalhadores do antecessor. Se a maior parte dos empregados sucedidos estiveram a coberto de um acordo precedente e o processo de produção for o mesmo, o sucessor estaria obrigado a participar da unidade de barganha, ainda que pudesse oferecer novo prazo e condições de emprego. No caso de reabertura de uma firma falida, com uma mesma gerência e as mesmas linhas de negócios, então é obrigada a aceitar os acordos precedentes. 


\subsection{Federação Americana do Trabalho (AFL)}

A tradição sindical nos Estados Unidos está fortemente ligada à American Federation of Labor (Federação Americana do Trabalho - AFL) de Samuel Gompers, ${ }^{40}$ organizada em 1886, com seu modelo de sindicalismo corporativista, comercial e excludente, do tipo "Craft Unions" (sindicatos profissionais). Seus membros eram quase que exclusivamente do gênero humano de cor branca e nacionalidade norte-americana. Em 1900, apenas 5\% pertenciam a sindicatos que foram organizados a partir destes trabalhadores especializados em máquinas, ferramentas mecânicas, carpinteiros, padeiros, estivadores, "craftsmen" como eram então designados estes artesãos e que foram os primeiros a se organizarem em suas especialidades em sindicatos locais e na determinação do Contrato Coletivo de Trabalho como sua arma principal para alcançar seus objetivos. Graças as suas habilidades e capacidades, tiveram uma posição relativamente forte para alcançar poder indutivo na esfera competitiva de valores e idéias junto à classe dominante e, destarte, influenciaram a política externa que se desenvolve, desde então, com a inclusão de instrumentos tradicionais e não-clássicos, na sua luta para alcançar seus objetivos estratégicos globais.

No seu primeiro $1 / 4$ de século de existência, sua batalha ferrenha foi caracterizada, principalmente, pela busca de melhores condições de trabalho e pelo direito de reconhecimento à própria sindicalização para a chamada "aristocracia dos trabalhadores", que contava com um complexo controle e estrutura hierárquica dos seus membros.

Dentre os diversos grupos que compunham as bases dos sindicatos trabalhistas, aqueles mais ideologicamente motivados com o socialismo ficaram insatisfeitos com o sistema horizontal que priorizava a profissão especializada e a negociação coletiva daqueles contratos. Alegavam que a AFL era por demais condizente com a ordenação existente, em vez de esforçar-se pela mudança do sistema, tradicionalmente, muito voraz quanto ao reconhecimento dos direitos elementares do trabalhador e cuja dimensão do processo histórico têm determinado, nas relações de produção, os sistemas de valores e normas. A facção socialista separou-se da AFL e fundou o seu próprio grupo que se denominou Trabalhadores Industriais do Mundo (Industrial Workers of the World -

\footnotetext{
${ }^{40}$ Fundador da American Federation of Labor (AFL).
} 
IWW $)^{41}$ ou "Wobblies" ou mesmo "I Won’t Work" (eu não quero trabalhar) como eram chamados então, e palavras cujas semânticas denotam uma característica preconceituosa de sindicalistas vacilantes e inseguros conquanto eram basicamente formados por imigrantes ainda não naturalizados, minorias raciais e mulheres que executavam os trabalhos mais penosos das indústrias no leste do país.

Fundada em 1905, a IWW defendeu a formação de "um grande sindicato", organizado em termos de indústria por indústria e que lutaria contra o capitalismo com greves gerais e, possivelmente, reorganizaria a economia com o controle dos trabalhadores.

Uma das mais significativas vitórias da IWW, nos três meses de conflito envolvendo 25.000 trabalhadores nas indústrias têxteis, foi a greve do pão e rosas "Bread and Roses Strike”, ocorrida em 1912. Foi um marco importante para a emancipação das mulheres na sua luta por maior justiça e contra a discriminação de gênero, pois foram elas, principalmente, que empunharam as faixas que induziam à adesão ao movimento grevista, com os dizeres "Queremos pão, mas rosas também”, embaladas pela música Greve do pão e rosas, cuja magnitude da letra enobrece o caráter solidário da luta que caracterizou a greve e que foi determinante na libertação da super exploração à qual crianças e mulheres trabalhadoras eram submetidas; pela beleza de sua representação de um modelo holístico de solidariedade e a lição de humanidade agregadas à sua letra, ressalte-se que foi o resultado de inúmeras reuniões das trabalhadoras.

A garota rebelde de James Oppenheim acabou por receber o crédito da letra deste poema-canção. "Garota rebelde", assim era conhecida Elizabeth Gurley Flynn, possuidora de grande eloqüência, militante desde dos 16 anos de idade na IWW e fundadora da Associação Americana de Liberdades Civis cuja liderança foi primordial no sucesso da negociação coletiva para as trabalhadoras: uma conquista da greve.

\section{LYRICS BY JAMES OPPENHEIM (Letra de James Oppenheim)}

As we go marching, marching in the beauty of the day,

(Assim que vamos marchando, marchando na beleza do dia,)

A million darkened kitchens,

(Um milhão de cozinhas obscuras,)

\footnotetext{
${ }^{41}$ Esta fase caracterizou o sindicalismo revolucionário de Big Bill Haywood, socialista utópico.
} 
a thousand mill lofts gray.

(mil sótãos cinzentos das tecelagens.)

Are touched with all the radiance that a sudden sun discloses,

(São tocadas com todo o brilho que um sol repentino desperta,)

For the people hear us singing:

(Para o povo escutar-nos cantando:)

"Bread and Roses! Bread and Roses!"

("Pão e Rosas! Pão e Rosas!")

As we go marching, marching we battle too for men,

(Assim que vamos marchando, marchando nós batalhamos também para os homens,)

For they are women's children and we mother them again.

(Visto que são filhos das mulheres e nós mães outra vez.)

Our lives shall not be sweated from birth until life closes.

(Nossas vidas não serão exploradas do nascimento até o fim da vida.)

Hearts starve as well as bodies;

(Corações famintos assim como os corpos;)

give us bread but give us roses.

(dê-nos pão, dê-nos rosas.)

As we go marching, marching unnumbered woman dead.

(Assim que vamos marchando, um sem número de mulheres mortas.)

Go crying through our singing their ancient call for bread.

(Vamos chorando através de nossa antiga canção que clama por pão.)

Small art and love and beauty their drudging spirits knew.

(Arte trivial e amor e beleza que suas almas escravizadas sabiam.)

Yes, it is bread we fight for, but we fight for roses too!

(Sim, é por pão que nós lutamos, mas lutamos por rosas também!)

As we go marching, marching we bring the greater days.

(Assim que vamos marchando, marchando nós guiamos os grandes dias.)

The rising of the women means the rising of the race,

(A ascensão das mulheres significa a ascensão da raça humana,)

No more the drudge and idler, ten that toil where one reposes.

(Não mais ao trabalho escravo e à indolência, dez que trabalharam duro onde um descansou.)

But a sharing of life's glories:

(Mas compartilhando as glórias da vida:)

Bread and roses! Bread and roses!

(Pão e rosas! Pão e rosas!) [Tradução livre] 
As indústrias têxteis da cidade de Lawrence (Massachusetts) empregavam metade dos 85.000 habitantes acima dos 14 anos de idade. A situação de exploração da mão-de-obra e o ambiente de insalubridade eram tão consternadores que 36 de 100 empregados morriam antes de completar os 35 anos. A seguir, fotos que ilustram a situação da época: ${ }^{42}$
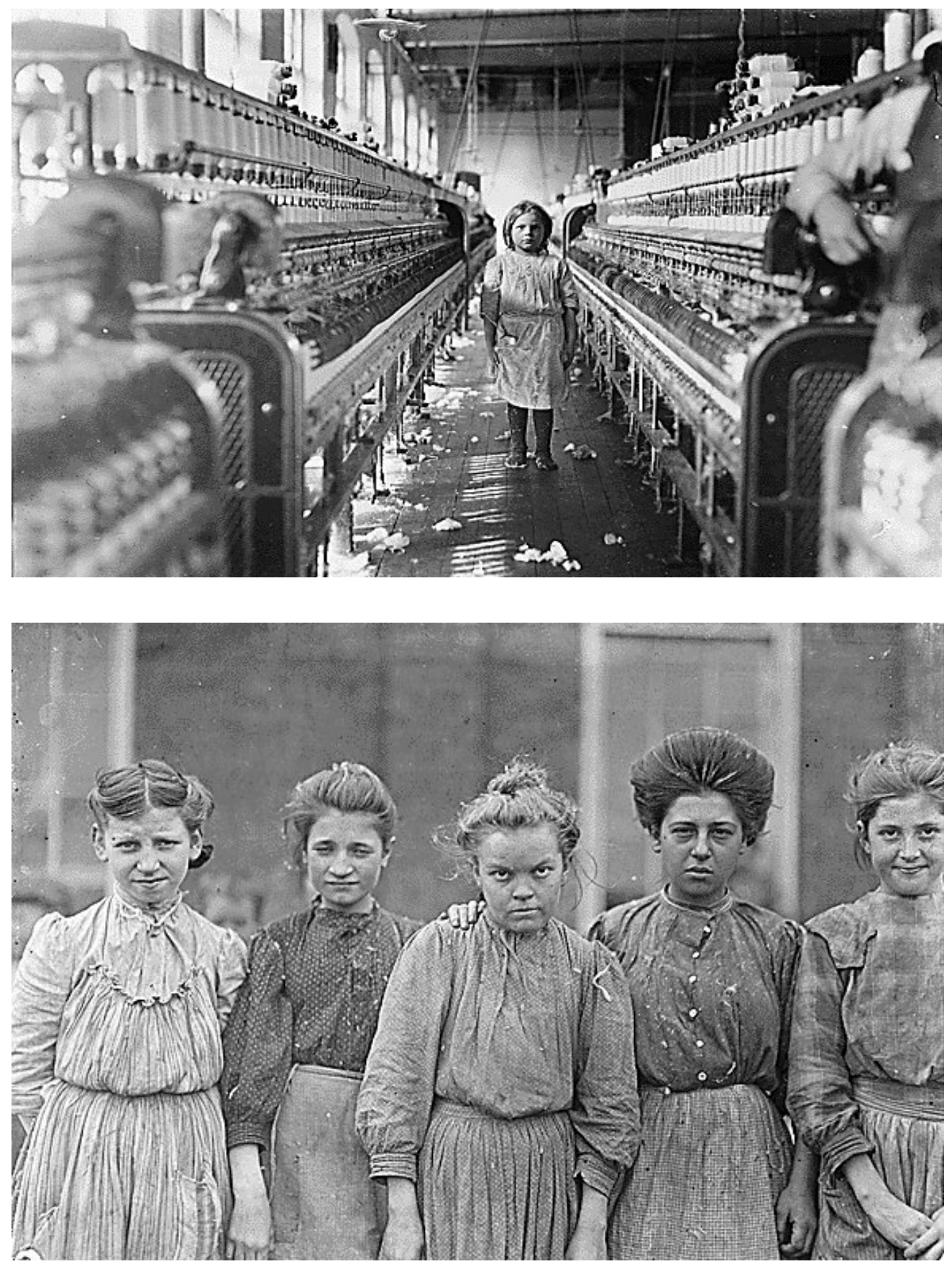

${ }^{42}$ Child Labor in America 1908-1912, fotografias realizadas por Lewis W. Hine. Disponível em: http://www.historyplace.com/unitedstates/childlabor. Acesso em 6 de março de 2006. 
Esta dura realidade, retratada nas fisionomias embrutecidas das crianças, fruto da ganância indescritível que dormita incansável nos recônditos do subconsciente, associada ao fordismo aplicado às máquinas têxteis, representavam uma ameaça à integridade física das crianças trabalhadoras, pois os patrões aceleravam a rotação das máquinas, obrigando-as a um trabalho desumano como forma de compensação de eventuais ganhos que as trabalhadoras pudessem receber, como tinham sido os vários casos de diminuição das horas semanais trabalhadas para mulheres e crianças através de leis estaduais, mudando de estratégias assim que a nova situação se configurasse mais adequada à exploração daquela mão-de-obra barata. Naquela ocasião, as horas semanais das trabalhadoras foram diminuídas de 58 para 56, ocasionando a aceleração da rotação para compensar as duas horas. Esta situação foi regulamentada somente em 1938, por intermédio da lei "Fair Labor Standards Act".

Os resultados da greve "Bread and Roses Strike" foram alvissareiros para outras categorias de mão-de-obra:

- $\quad 15 \%$ de aumento salarial.

- $\quad$ Hora extra em dobro.

- Sem retaliação aos grevistas.

- Padronização da rotação das máquinas.

- $\quad$ Fim da discriminação a estrangeiros.

São estas situações extremas que levam os trabalhadores a agirem em prol de sua própria sobrevivência cujo estado mais consternador tem sido a escravidão, sendo que a emancipação consolidada pelos anglo-saxões revigorou a hegemonia dos valores capitalistas excludentes.

A IWW organizou sindicatos que a AFL tinha excluído e foi acusada de enfraquecer o movimento sindical por ter sido a causadora da desunião do trabalho organizado norte-americano. As instituições políticas norte-americanas têm limitado o crescimento do socialismo por razões da própria dinâmica do processo histórico inerente ao povo norte-americano, cujas raízes derivam de suas origens étnicas, mais o desenvolvimento complementar que se verificou nas relações acirradas das disputas na Guerra de Secessão e da própria conquista do Oeste, geraram certa falta de coesão entre seus concidadãos. 
Desde o final do século XIX, a corte suprema de justiça norte-americana tem sido sui generis quanto à sua independência, no sentido de proteger a propriedade particular e rejeitar quaisquer legislações que pudessem ser consideradas contrárias aos negócios. Aqui os sindicatos dos trabalhadores têm tido que lutar muito para provar que seus Contratos Coletivos de Trabalho nunca tiveram a pretensão de serem contra os negócios, mas sim, contra a ganância de patrões inescrupulosos. Existem sindicatos que procuram tirar proveito de certas situações, mas historicamente a regra que prevalece tem sido sempre a da supervalorização do capital em relação à mão-de-obra.

É consensual entre a população norte-americana que os programas de bem-estar social é direcionada, exageradamente, de modo desproporcional para as minorias e que estas são ociosas, parte do pretexto democrático que a sociedade aberta provê oportunidades, só não as usa quem não as quer! Com a crise de 1929, as pretensões socialistas de mudanças radicais através de eleições foram relegadas e banidas do cenário norte-americano.

Em 1935, um grupo dissidente da AFL liderado pelo legendário John L. Lewis então presidente do Sindicato dos Trabalhadores em Minas (United Mine Workers UMW) formou um comitê denominado "Committee for Industrial Organization". Em contrapartida, como esse comitê foi bem sucedido em arregimentar novos membros, a liderança da AFL foi ameaçada e, em 1938, numa decisão histórica, a AFL não só descredenciou os sindicatos dos trabalhadores da indústria automobilística, do aço e das minas, como também desqualificou o politicamente militante sindicato do vestuário feminino (International Ladies Garment Workers Union - ILGWU). Os dissidentes reiteraram seu desagravo com a proclamação de sua independência, elegendo um novo nome para aquela arregimentação, mantendo as mesmas iniciais: Congress of Industrial Organizations (CIO).

O período seguinte à crise de 1929 foi bastante agitado (mais de 9 mil bancos e 85 mil empresas decretam falência, a cotação das ações cai em média 85\% entre 1929 e 1932). A redução de salários chegou a 60\% e o desemprego atingiu 13 milhões de norteamericanos. Nesse contexto, o crescimento de sindicatos industriais propiciou a criação desta grande central de trabalhadores de esquerda após uma série de rebeliões, combatidas exaustivamente pelas autoridades, e que determinou o segundo movimento "Red Scare" anticomunista (1940-1950), dando inicio à campanha radical de direita denominada 
macarthismo, que se caracterizara por fazer acusações, insinuações e delações sem provas cabais. A CIO foi formada com o intuito de agregar ao sindicalismo o crescente número de trabalhadores nas indústrias em fase de aproveitamento racional e intensivo dos fatores de produção da qual podemos destacar a indústria siderúrgica e a automobilística.

Adaptando-se ao declínio da produção manufatureira mais artesanal frente à produção em massa, no momento que o taylorismo maturava, a CIO adotou o conceito da IWW de organização por indústria, realçando a transformação do conceito corporativista da AFL que não mais condizia com o crescimento escalar da economia norte-americana.

A CIO era uma mescla de sindicalistas mais radicais com dirigentes que propalavam poderes iguais aos seus membros. Foi expulsa da AFL pelo seu desafio ao sindicalismo mais comercial, mas fundiu algumas experiências tradicionais da AFL, tais como: contratos obrigatórios, diretoria mais profissionalizada, concentração de poder em nível nacional e aliança partidária mais progressista. Após a transição da Lei Wagner (National Labor Relation Act, 1935) estas práticas vieram a se integrar, rapidamente, dentro da estrutura nacional de barganha coletiva, institucionalizada por lei federal do trabalho.

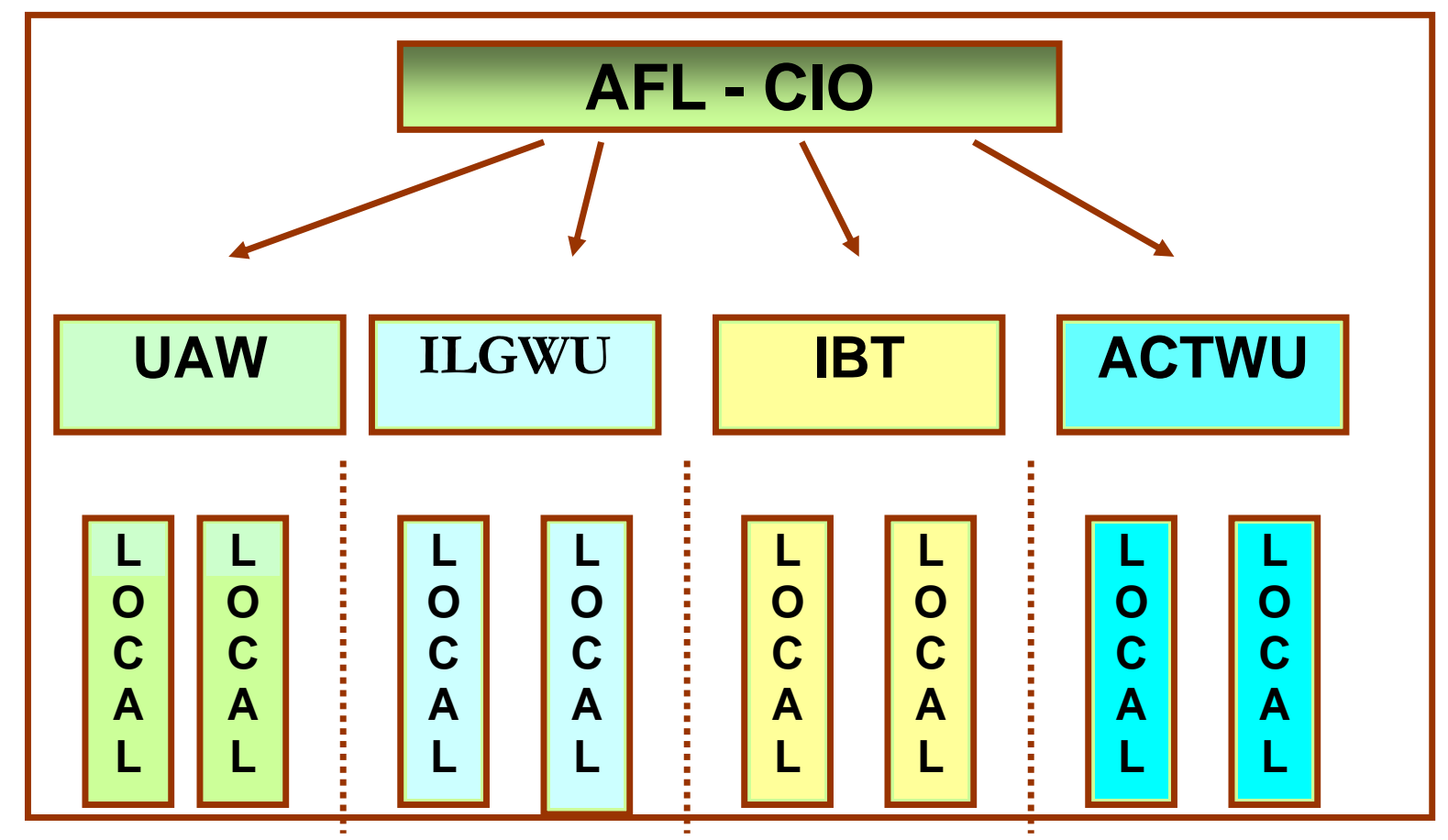

UAW - United Auto Workers

ILGWU - International Ladies Garment Workers Union

IBT - International Brotherhood of Teamsters 


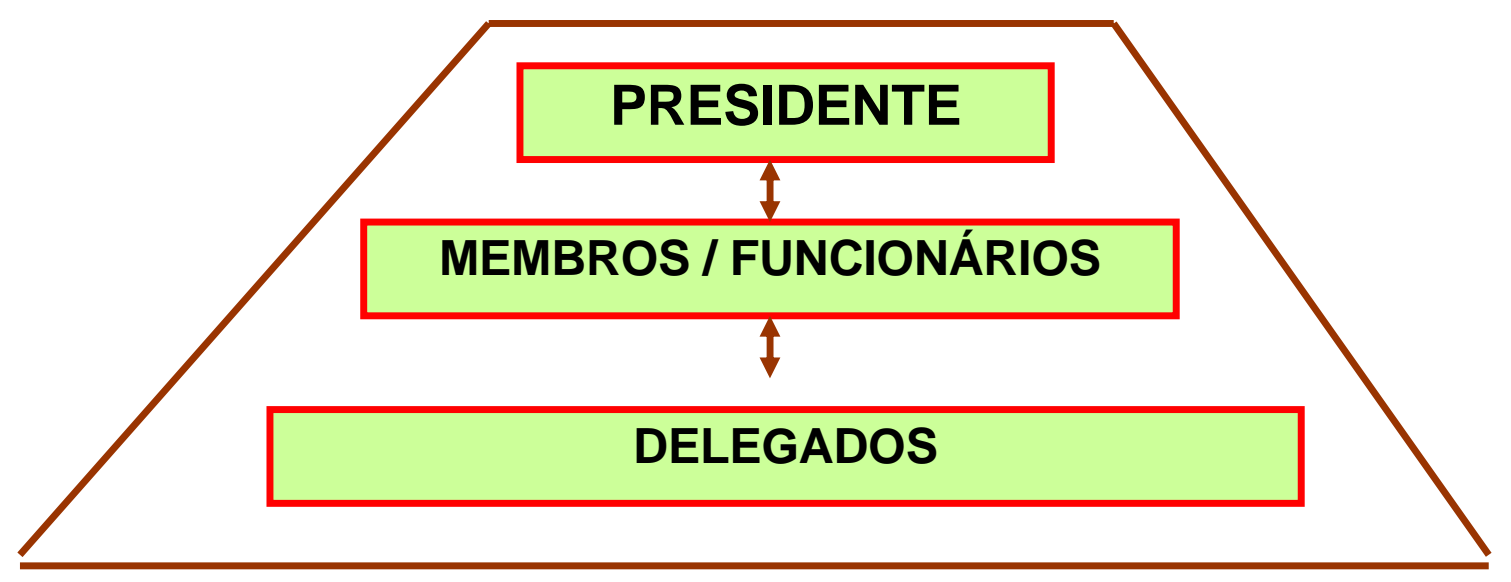

O diagrama identifica os principais quadros da estrutura da AFL-CIO:

\section{Estrutura da AFL-CIO}

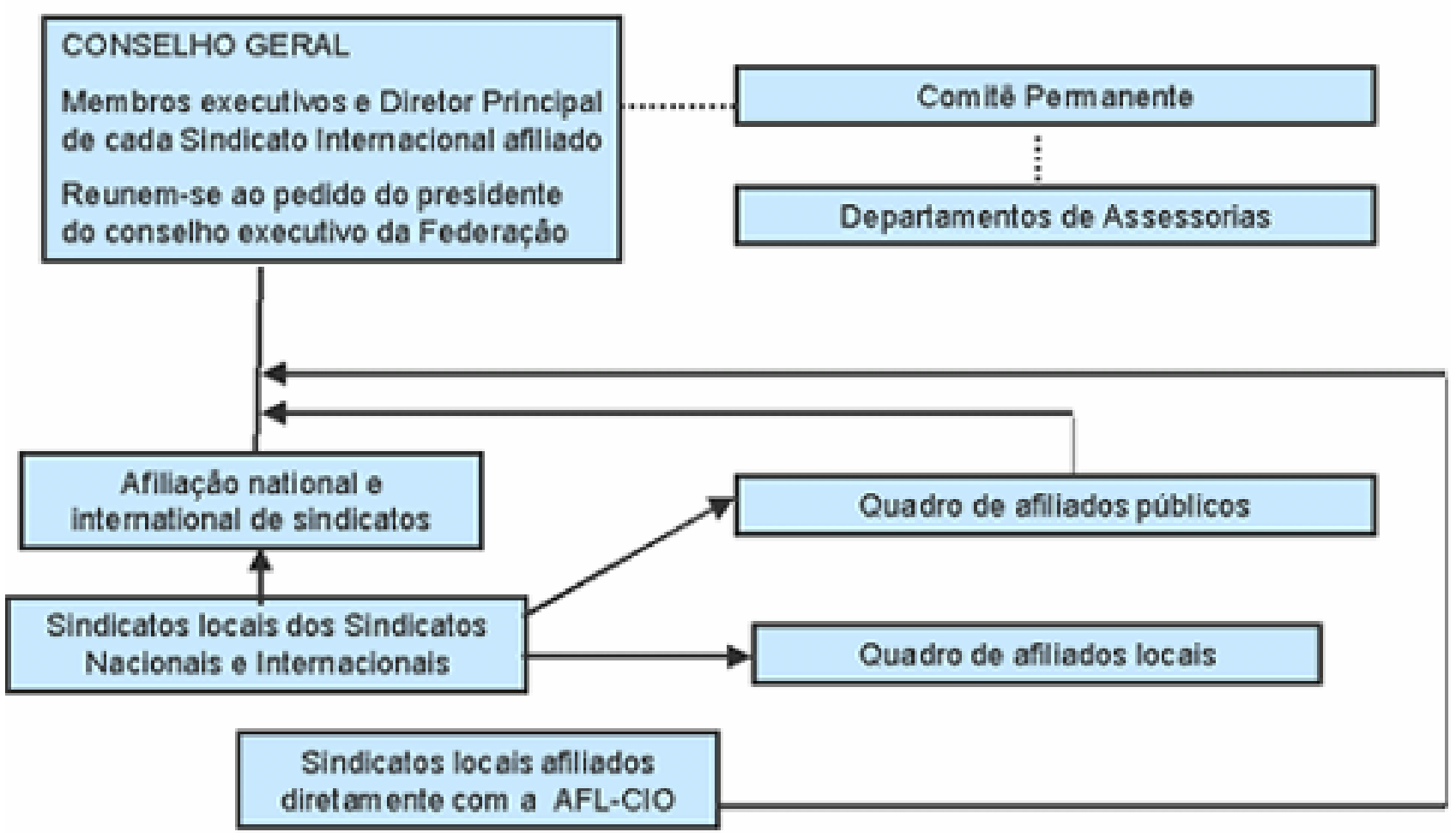




\subsection{A lei trabalhista e os sindicatos}

Para os legisladores estadunidenses, os sindicatos nunca alcançaram o êxito almejado dos trabalhadores, pois tanto os Estados como a própria União sempre tiveram uma posição pró-empregadores e mesmo as diversas Cortes Públicas, invariavelmente, têm tido uma interpretação da lei mais favorável ao empregador. A história das leis trabalhistas norte-americanas tem sido a própria história dos trabalhadores nas formulações estratégicas dos Contratos Coletivos de Trabalho, na defesa intransigente das condições de trabalho e de melhores salários e, de maneira precípua, pela delimitação institucional e a luta pela pressuposta ilegalidade de seus movimentos no ordenamento jurídico.

Exceção feita após outubro de 1929, quando houve a queda da Bolsa de Nova York, em conseqüência da grande depressão econômica, quando o desemprego alcançou cifras alarmantes. E foi graças à posterior recuperação da economia, que trouxe aumento de empregos e o crescimento espetacular de novos sindicalizados, que os trabalhadores fortaleceram-se nos aspectos político e econômico, de acordo com a segunda onda de reformas do "New Deal" 43 por intermédio do qual o governo se propunha a determinar o tipo de relacionamento mais conveniente com as organizações trabalhistas. Após o sufoco do desemprego em massa, os trabalhadores sindicalizaram-se a fim de fortalecer o sindicato, posição que perdurou até mesmo após a Segunda Guerra Mundial. Cresceu sobremaneira a filiação aos sindicatos, atingindo o ápice entre os anos de 1940 a 1950 (36\%), acompanhando o desenvolvimento tão grandioso da economia que caracterizara bem a época em função das indústrias manufatureiras já bem consolidadas e em crescente transformação com economias de escala.

A discussão teórica de que a lei afeta o desempenho da economia do mesmo modo que a lei em si é importante para o controle da economia se recrudesce quando se invoca a escassez, uma das características do conceito da lei econômica, que acaba por configurar e limitar de fato a atuação das leis jurídicas quando se evoca o social. A preponderância que tem, nos Estados Unidos, o livre fluxo do comércio, em nível constitucional, orienta a predisposição de não reconhecer nos sindicatos, nem mesmo nas

\footnotetext{
${ }^{43}$ A nova política do bem-estar social do presidente norte-americano Franklin D. Roosevelt (1933 a 1941) que se baseou na nova política econômica de John Maynard Keynes, conseqüência do ápice da crise econômica em 1929.
} 
próprias normas jurídicas, a suplantação da imperatividade que determina a lei econômica de procura e oferta. A predisposição contemporânea de encarar como forma de mercadoria todos os fatores de produção contraria o consenso de boa índole para o qual o fator de trabalho humano, através do Direito do Trabalho consciente, tem tido um papel regulador e protetor da dignidade humana com a valorização dos direitos fundamentais. Entre a teoria e a prática há diferenças defasadas, da mesma maneira, entre a teoria do Direito do Trabalho na exigência de um direito adquirido e a prática econômica, de fato.

Foi a partir da obra de Jean-Jacques Rousseau (1712-1778), ${ }^{44}$ Du Contrat Social (1762), muito discutida e na qual afirmara que os homens nascem bons, mas carentes de acuidade moral e responsabilidade, que o direito individual permeia-se com o direito coletivo numa tentativa de harmonização. A regulamentação dos contratos pessoais da lei cível para a lei trabalhista foi um marco na história das relações do capital versus trabalho que evidencia a epopéia dinâmica das relações humanas, de modo que a soberania da "voluntas" das partes transforma-se numa ferramenta poderosa da ordem do fato, mas não a interpreta como compleição teórica da sabedoria. A seguir, o elenco das principais leis federais que têm orientado as relações de trabalho nos EUA:

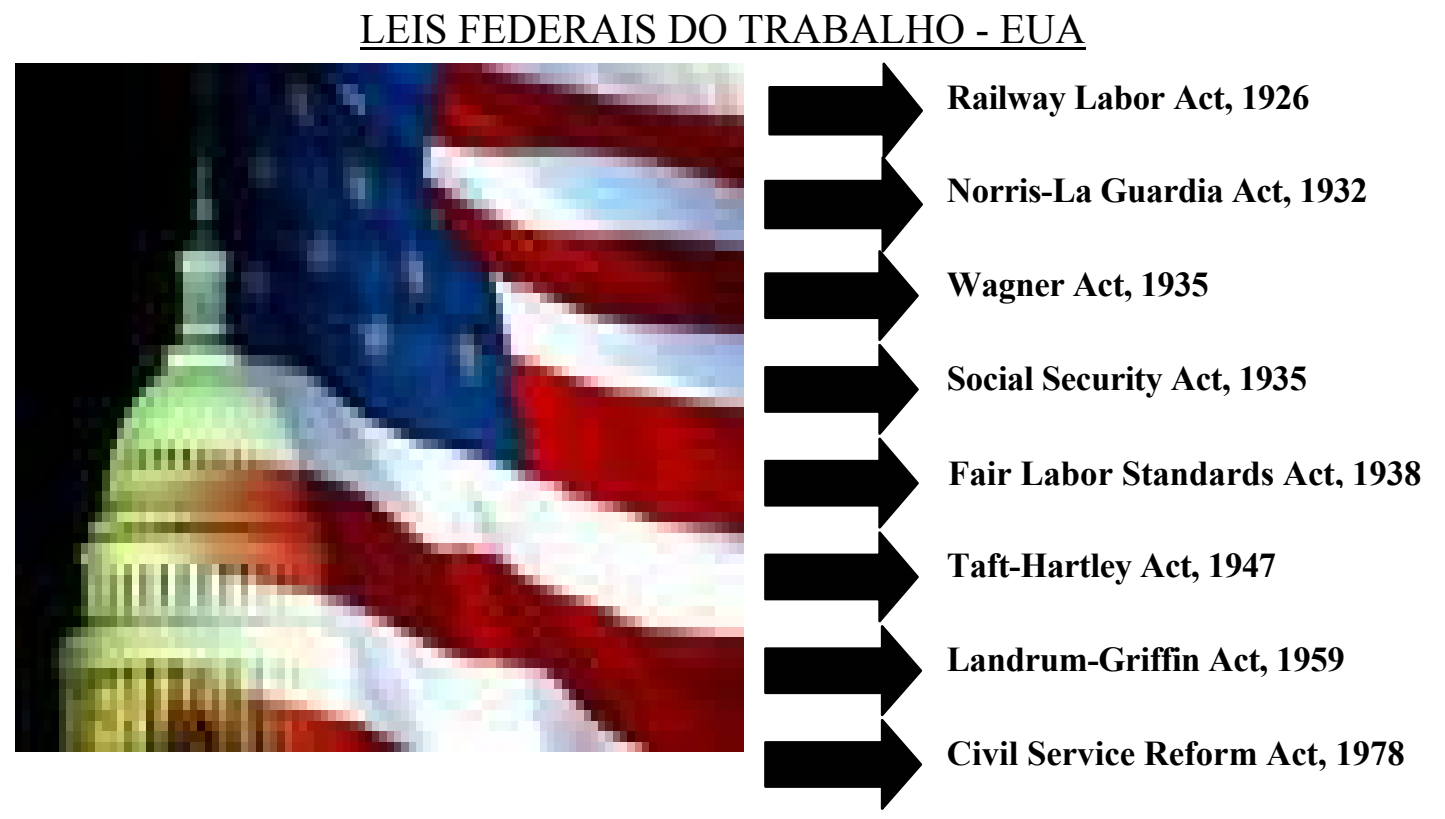

\footnotetext{
44 O estado moderno caracteriza-se fundamentalmente por ser laico; a laicização foi um processo que culminou com a revolução francesa (1789-1815). A justificativa moral adveio de que sentimentos tais como a compaixão são próprios dos seres humanos e não infundidos por temor a uma divindade, pois estes decorrem da própria natureza humana, muito embora os homens se associem por necessidade, diferentemente da concepção hobbesiana, que embora também seja imperiosa a necessidade de associação, o homem não é naturalmente bom.
} 
A seguir, breve panorama das principais leis federais do trabalho:

\section{National Railway Labor Act - 1926}

Foi o marco institucional mais significativo nas relações do capital e trabalho e serviu de parâmetro para as legislações que se seguiram, pois sua excelência foi fruto da interação equilibrada entre empregados e empregadores que, conjuntamente, trabalharam com dignidade e técnica na tentativa de resolver suas acirradas disputas. Como resultado desta interação coletiva justa e transparente, não houve greve significativa no setor até o início dos anos 60. A lei permite que ferroviários e aeroviários formem sindicatos sem a interferência do empregador. Proíbe às Cortes Federais o despacho de injunções (uso coercitivo da lei; tutela antecipada provisória) em disputas trabalhistas pacíficas envolvendo termos, condições de emprego e representação sindical.

Antes do surgimento dessa lei, a influência coercitiva era baseada no decreto-lei federal "The Sherman Antitrust Act" que procurava regular os trustes corporativos ou quaisquer iniciativas que eventualmente restringissem ou limitassem os negócios e o comércio. Na interpretação das Cortes Públicas, os sindicatos representavam um obstáculo quando se organizavam ou entravam em greve, garantindo, assim, uma injunção contra os trabalhadores por violação do dito decreto-lei.

A "National Railway Labor Act" trouxe uma difusão considerável do Contrato Coletivo de Trabalho, com a criação do "National Mediation Board" na mediação, práticas discriminatórias e resolução dos arbítrios somente entre ferroviários e aeroviários. Essa lei foi o estandarte da legislação federal na construção da regulamentação trabalhista mais abrangente do Contrato Coletivo de Trabalho através da formulação da lei proposta pelo senador Wagner também conhecida como "National Labor Relations Act".

\section{Norris-La Guardia Act (Anti-Injunction Act) - 1932}

Permite aos empregados a formação de sindicatos sem a interferência do empregador. Delimita, expressamente, o poder do Tribunal Federal, na aplicação de injunções (tutelas provisórias antecipadas) contra as atividades sindicais nas disputas trabalhistas, denotando forte componente progressista quando sinalizara a regulamentação de piquetes e outras táticas dos empregados. Entretanto, permite a tutela antecipada em 
casos de atividades ilegais e aquelas que poderiam pôr em perigo a saúde e segurança nacional. Suprimiu os "yellow dog contracts" nas quais os empregadores obrigavam o empregado a não se juntar ou dar assistência aos sindicatos. O termo "yellow dog" remete-nos aos anos 1880/1890 quando a lei ordinária (common law) ${ }^{45}$ era associada ao que convencionaram chamar de lei de cachorro (dog law) no sentido de que, para se treinar um cão, há a necessidade de muito castigo.

O ambiente econômico de recessão proporcionado pela crise econômica de 1929, quando o desemprego elevou-se de 3,2\% para 25,2\%, produzindo contingente de 13 milhões de desempregados, foi o acontecimento extraordinário que permitiu $\mathrm{o}$ reconhecimento de certos direitos trabalhistas, principalmente o Contrato Coletivo de Trabalho que sinalizara a mudança de atitude anti-sindical do governo em relação aos sindicatos dos trabalhadores no período de 1935 a 1947. A execução da lei, entretanto, nem sempre coincidia com a intenção do legislador e as práticas trabalhistas de fato, pois que o empregador continuara com total liberdade de lutar contra as organizações trabalhistas, utilizando instrumentos ambíguos, quando aquela admitia interpretações diversas.

\section{Wagner Act - 1935 (National Labor Relations Act)}

O caos provocado pela grande depressão de 1929, intensificou o desejo dos trabalhadores quanto à uma legislação nacional mais abrangente no sentido de pôr fim às interferências judiciais e do empregador para com as atividades dos sindicatos. Esta tem sido a lei nacional das relações trabalhistas que força o empregador a negociar com os sindicatos "em boa fé", sendo a não-observância deste item considerada uma "prática discriminatória" e, por conseguinte, sujeita às punições da lei. Recusar as responsabilidades e obrigações pelas quais uma negociação coletiva tem o dever de se pautar, ou omitir-se perante elas, determina uma violação intrínseca e, portanto, uma conduta injusta e ilegal. A lei, ainda, declara proteção federal ao direito de formar sindicatos, barganhar coletivamente por um representante eleito democraticamente e atividades de greve e piquete.

\footnotetext{
${ }^{45}$ Como reflexo do sistema inglês de leis que se desenvolveram pelos costumes e decisões de juízes, mas não criadas pelo parlamento. Nos EUA, tais leis variaram substancialmente de estado para estado, dificultando a organização de sindicatos, bem como uma política nacional de trabalho.
} 
Assim, os sindicatos civis têm os privilégios de representação exclusiva e direito à cobrança de uma taxa de todos daquela unidade, desde que o empregador esteja de acordo, inclusive de quem votou contra, sendo o valor da taxa estipulado arbitrariamente. Estas taxas sindicais podem ser descontadas pelo empregador em folha de pagamento com autorização por escrito do empregado, portanto não é permitido o desconto em folha, compulsoriamente, o que seria considerado uma prática desleal. Entretanto, esta lei não se aplica à maioria dos sindicatos do setor público, aos militares e ao pessoal de escolas pela razão de que sindicalismo compulsório, nesses casos, politizará excessivamente o governo, fazendo-o mais dispendioso e ineficiente e podendo causar problemas de segurança pública. Muitos Estados partilham desta razão e não estabeleceram Contrato Coletivo Obrigatório para seus empregados públicos. Esta lei tal qual foi promulgada em 1935 transmudou de forma radical as relações das empresas com os trabalhadores. Com efeito, o Congresso americano emendou esta lei diversas vezes, no sentido de restaurar o equilíbrio entre ambos. Em resumo, esta proíbe práticas injustas do empregador quanto a:

- Restrição aos empregados de exercerem seus direitos.

- Ameaça de perda de benefícios.

Emendas a esta lei garantem direitos de não-sindicalização mesmo em estados que permitem a "union shop", que consiste na contratação de um empregado nãosindicalizado com o compromisso a posteriori de sindicalizar-se.

A criação da NLRB (National Labor Relation Board) foi para administrar e executar esses direitos e é considerada a alma das leis trabalhistas.

4. Social Security Act -1935

- Promulgada em Agosto de 1935 por F.D.Roosevelt como parte do segundo estádio do "New Deal", através do Comitê de Segurança Econômica;

- $\quad$ Pagou o primeiro benefício em 1940;

- Programa de seguro social em escala nacional para atender às necessidades do idoso e do desempregado;

- Pretendia ser um benefício (pensão) às viúvas; 
- $\quad$ Em 1937, a taxa sobre a folha de pagamento era de 2\% e hoje é de $12.4 \%$ (metade empregadora, metade empregado);

- $\quad$ Em 1937, a expectativa de vida era de 59.7 anos e a aposentadoria ocorria aos 65 anos. Hoje a expectativa de vida é de 77.4 anos e a aposentadoria ocorre aos 65-67 anos.

\section{Fair Labor Standards Act - 1938}

O congresso negou por três vezes leis similares a esta, denotando sua tradicional complacência extensiva aos interesses corporativos. A proposta desta lei foi iniciativa do terceiro estádio do New Deal (1937/38). Seu principal objetivo foi a regulamentação do salário mínimo em US\$ 0,25 por hora, 40 horas semanais (horas extras: uma vez e meia após as 40 horas) e do trabalho de crianças. Atualmente, o salário mínimo urbano varia de US\$ 5,15 a US\$ 7,93 de acordo com a competência dada aos estados em legislar sobre esta matéria. Aprovada a lei, as condições das crianças foram regularizadas assim:

- Crianças de 14 e 15 anos de idade podem trabalhar fora do horário escolar desde que não seja em indústrias, minas e trabalhos perigosos e dentro das seguintes condições: não mais de 3 horas em dia de aula e 8 horas em dia que não tem aula. Com 16 anos já podem trabalhar na maioria dos empregos não-rurais e, com 18 anos, em empregos não-rurais declarados pelo Ministério do Trabalho como perigosos ou arriscados.

- Regulamentou também a obrigação do patrão em manter arquivado, em até 3 anos, os registros completos dos trabalhadores.

Instituiu duas categorias de empregados:

EMPREGADOS ISENTOS, QUE NÃO RECEBEM SALÁRIO MÍNIMO E HORAS-EXTRAS.

1. Gerentes, especialistas, executivos, vendedores externos; fazem testes de adequação salarial e de cargo.

2. Trabalhadores voluntários e prestadores de serviços.

3. Motoristas de táxis, trabalhadores rurais, domésticas e marinheiros. 
4. Garçons, "office-boys", ${ }^{46}$ estagiários, mensageiros, que são designados de "tipped job" ${ }^{47}$ onde a gorjeta é sempre maior que o próprio salário, cujo salário é, hoje, de US\$2,13 a hora.

\section{EMPREGOS NÃO-ISENTOS.}

1. Obrigados a pagar salário mínimo e horas-extras. Já foi emendada (última emenda em 1996) diversas vezes desde então.

\section{Robert Taft-Fred Hartley Act ${ }^{48}-1947$}

Lei que delimitou as atividades sindicais como resposta do governo. Ao ser pressionado pelos setores empresarial e financeiro, concordou com o que consideraram excessivo poder de barganha dos trabalhadores reunidos em sindicatos. Conhecida como a lei que regula as relações do trabalhador com as empresas, a Labor-Management Relations Act proíbe práticas discriminatórias dos sindicatos dos trabalhadores:

- Coerção de companheiros trabalhadores.

- Ameaças físicas.

- Obtenção de tutela antecipada provisória para deter o progresso de greve com mais de 80 dias de duração, dada ao presidente dos EUA, quando se trata de problemas de saúde e segurança nacionais.

- Os "close shops" que são acordos por meio dos quais o empregador só contrataria membros de determinado sindicato na hora da efetivação.

- O que se convencionou chamar de "boicote secundário" que é a inibição de transações de uma terceira parte com o intuito de punir ou constranger o empregador; designada, também, por greve de solidariedade. Tal prática é considerada discriminatória pela legislação federal (NLRA) e por vários Estados e, portanto, considerada ilegal.

- Greves e boicotes jurisdicionais.

A lei permite aos chamados "Union Shops" na qual o empregador pode contratar um não-sindicalizado, mas este tem que se sindicalizar, no máximo, em 7 dias para não perder o emprego e também as "Agency Shops" cujo sistema permite a um

\footnotetext{
${ }^{46}$ Aprendiz de escritório; contínuo.

${ }^{47}$ Empregos nos quais a gorjeta é prática usual.

${ }^{48}$ A lei conhecida como Taft-Hartkey Act foi uma emenda à Lei Wagner (Wagner Act) feita pelo Congresso com a finalidade expressa de equilibrar o poder entre sindicato e empresas.
} 
sindicato legalizado receber uma quantia de dinheiro de não membros, equivalente à taxa sindical dos membros efetivos. Tem a intenção de eliminar a corrupção nos sindicatos de trabalhadores exigindo mais divulgação dos fundos sindicais e a responsabilidade pelo seu devido uso bem como eleições regulares de seus mandantes.

\section{Landrum-Griffin Act - 1959 ou The Labor-Management Reporting and Disclosure Act (LMRDA)}

Esta lei surgiu em cena, principalmente, para proteger o trabalhador da forte onda de violência, bem como da corrupção que imperava junto aos dirigentes sindicais devassos, geralmente em conluio com os empregadores e o crime organizado. A lei surgiu como conseqüência da pilhagem nas finanças sindicais e na não observância dos direitos mais elementares dos trabalhadores sindicalizados. Em suma, foi ordenada visando ao maior controle governamental dos negócios internos dos sindicatos de trabalhadores. A Declaração de direitos aos sindicalistas incluía:

- Liberdade de discurso, eleições secretas, direito de processar o sindicato, limite na cobrança das taxas.

- Exceção ao "close shop" ${ }^{49}$ somente para construtoras que estabelecem a contratação de emprego através dos sindicatos. Procura o equilíbrio desde que a construtora individualizada esteja à mercê de um tradicional sindicato forte.

- A obrigação dos dirigentes sindicais de apresentarem relatórios de transações financeiras.

Restrição a certos tipos de boicote e piquete:

- $\quad$ Piquete a favor de sindicatos não certificados.

- Arranjos entre sindicatos cujos sindicalizados recusam-se a trabalhar em materiais advindos de trabalhadores não-sindicalizados, ou mesmo quando esteja ocorrendo uma greve na fábrica que produz bens intermediários.

- Boicotes secundários ou de solidariedade.

\footnotetext{
${ }^{49}$ Modelo em que o empregador concorda em contratar somente os trabalhadores sindicalizados.
} 


\section{Civil Service Reform Act (CRSA) - 1978}

Substituiu as normas executivas governamentais como lei básica que rege as relações trabalhistas dos empregados federais. Protege os direitos de negociação para os empregados públicos na maioria das agências executivas do governo federal, incluindo a biblioteca do congresso e o serviço de impressão governamental. Esta regulamentação põe em prática os padrões de conduta prescritos pela Labor-Management Reporting and Disclosure Act (LMRDA). Como parte desta lei, foi instituído o estatuto Federal Service Labor-Management Relations Statute (FSLMRS) que regula a formação, participação e oferece assistência pública às organizações trabalhistas, como:

- Instigar, participar ou ignorar ou aceitar como inofensiva uma greve, paralisação intermitente ou operação tartaruga que são consideradas práticas desleais e o certificado pode ser anulado.

- Cerca de 32 estados permitem a negociação coletiva dos servidores públicos com ampla legislação estadual trabalhista prescrita por órgãos estaduais próprios em que cuidam das vinculações empregatícias. 


\subsection{Classificação dos sindicatos nos EUA}

A classificação de um sindicato pode ser feita de várias maneiras, de acordo com os seguintes critérios:

- sociais;

- $\quad$ econômicos;

- funções históricas;

- geográficos.

A organização horizontal leva em consideração a profissão exercida pelos sindicalizados, sem relevância para a empresa onde trabalham; constituída como a mais antiga e tradicional forma de organização sindical nos EUA deu origem aos "craft union" (sindicatos profissionais).

Por outro lado, tem-se o sindicato vertical, no qual tem importância a índole da atividade desenvolvida pela firma e não a profissão, propriamente. Da forma vertical originou-se a "company unions", ou mesmo "industrial unions" conforme a descrição estrutural dos sindicatos estadunidenses como segue abaixo:

\section{A. Sindicato Profissional (Craft Union)}

Trabalhadores que têm como vínculo comum um mesmo conjunto de experiência, a mesma profissão. São organizados segundos os princípios de exclusão. Têm consciência de emprego e da necessidade de seus conhecimentos para o empregador e poderíamos denominá-los de bastante especializados. O gráfico abaixo mostra como têm agido para alcançar seus objetivos. 


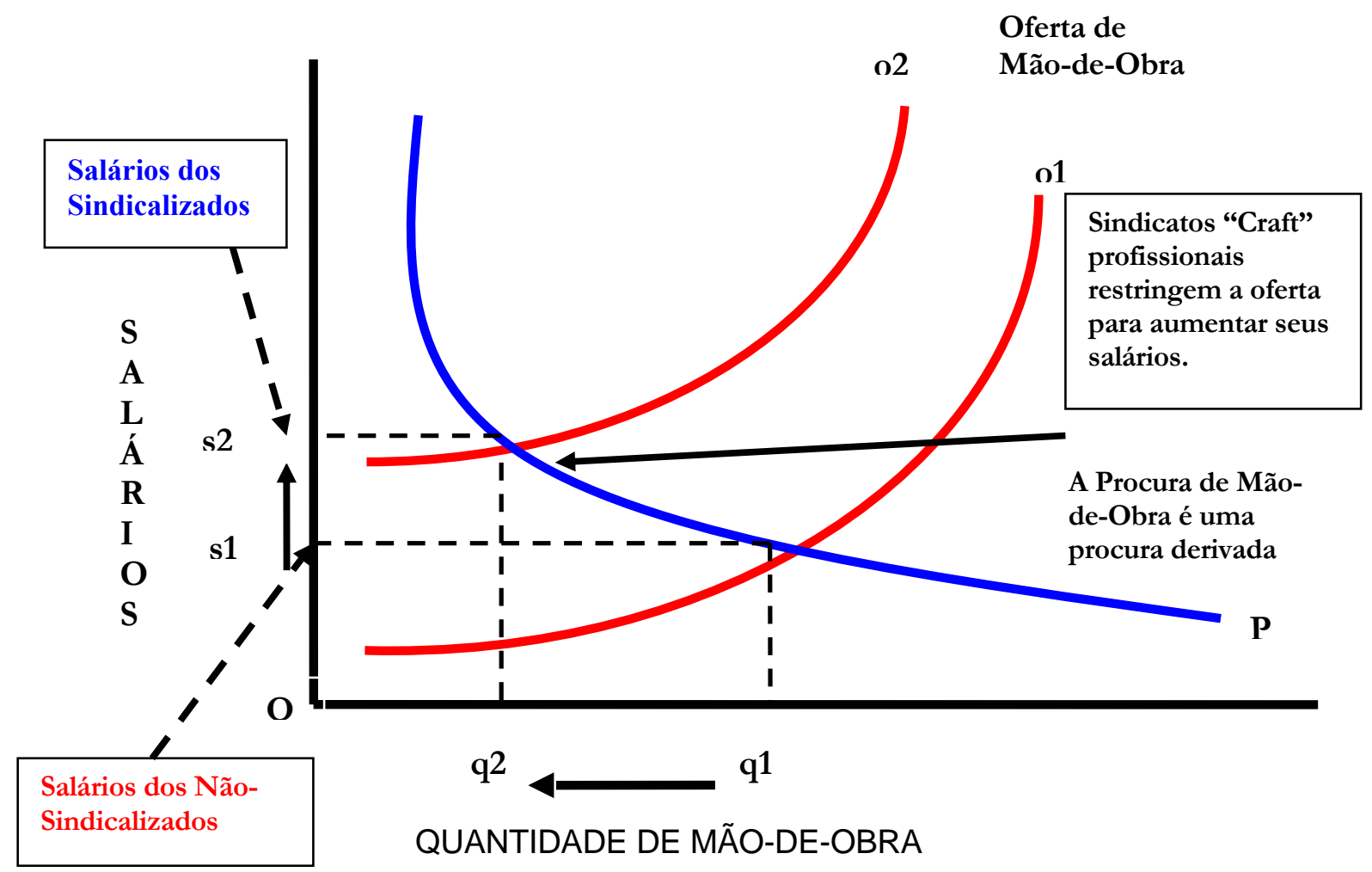

* Refere-se a profissões com maior poder de barganha, dada a sua especialidade, e por isso caracterizam bem o "Craft Union". Exemplificando: os ferramenteiros, segundo índice de negociação de Nash (Nash Bargaining Maximin), ${ }^{50}$ têm um poder de barganha muito maior do que os torneiros mecânicos. $\mathrm{O}$ índice de Nash identifica o grau de poder de barganha dos diversos atores na negociação coletiva. Com o índice de Nash, os sindicatos e as empresas barganham no Contrato Coletivo a taxa do salário, ou seja, horas de trabalho, de acordo com a seguinte fórmula:

$$
\mathbf{\Omega}=\mathbf{U}^{\beta} \Pi^{1-\beta}
$$

$\mathbf{U}$ é a função utilidade do sindicato, $\Pi$ o lucro da empresa e $\boldsymbol{\beta}$ representa o poder de barganha do sindicato.

O Contrato Coletivo de Trabalho é definido, em termos gerais na teoria dos jogos de Nash, como a negociação entre o empregador e o sindicato de trabalhadores em que se procura um nível de equilíbrio que satisfaça as partes. Este pressupõe que as partes são bastantes racionais e igualmente capazes, que compartilham conhecimento mútuo e adequado de suas respectivas predileções e preferências segundo parâmetro que possa ser

\footnotetext{
50 John Nash, matemático da Universidade de Princeton, publicou em 1950 sua teoria do jogo, mas foi somente reconhecido, primeiramente, pelos economistas e depois por profissionais de outras áreas, que constataram quão fundamental tem sido sua teoria baseada em modelo matemático, sendo agraciado em 1994 com o Premio Nobel.
} 
considerado razoável. O fato de os atores expressarem opiniões diferentes, quanto ao que pode ser considerado razoável, demonstra a variação que pode existir neste conceito, não só da razoabilidade, mas também em termos de aptidão e competência. Também parte do pressuposto de que numa greve nenhuma das partes detém uma razão intrínseca para colaborar, então, nesta teoria, a situação é a de um jogo não-cooperativo, provendo a competição com ferramentas privilegiadas ao mais apto e relegando a justiça a um plano inferior. É, outrossim, um modelo ótimo para culturas que já atingiram certo grau de sofisticação, entretanto costuma ser inadequado na maioria dos casos em que o trabalhador tem sido visto como hipossuficiente na defesa de seus direitos.

Um episódio clássico deste embate ocorreu na primeira gestão do governo Ronald Reagan $^{51}$ (1980-1984), envolvendo os controladores de vôo em greve que, cientes de sua condição privilegiada de barganha $(\beta)$, exerceram pressão considerável sobre o governo que os demitiu; e, assim, obtiveram uma derrota histórica. A aplicação da lei "The Norris-Laguardia Act", não permite greve quando impacta diretamente a segurança pública; neste caso, subentende-se que a essencialidade no andamento dos negócios foi indevidamente perturbada pela greve. E, por mais contraditório que pareça, tal medida veio das mãos de um ex-membro do sindicato dos atores que havia recebido o apoio total daquele sindicato na sua eleição em 1980. Em agosto de 1981, Ronald Reagan, voluntariamente, demitiu os grevistas controladores do tráfego aéreo (Professional Air Traffic Controllers Association-PATCO), depois de haver sido declarada ilegal; ação esta que assinalou para o setor privado que a contratação de substitutos não só era legal, como plenamente aceitável! Observe-se que o viés político desta atitude anti-sindical tinha a finalidade de mostrar ao sindicato que ninguém é insubstituível, numa clara demonstração de afronta ao seu mandonismo.

Seria possível denominar estes sindicatos de "sindicatos restringíveis" que, historicamente, são bastante parecidos com as guildas da Idade Média, pois agrupavam cidadãos com interesses comuns, tais como: comerciantes, artífices, artistas que recebiam assistência e proteção. Estes sindicatos de trabalhadores mais especializados, formados por marceneiros, pedreiros, encanadores, e tipógrafos, restringiam artificialmente a oferta

51 Ronald Wilson Reagan (1911-2004): quadragésimo presidente norte-americano, conservador e intervencionista; seus oito anos de mandato foram identificados com os princípios neoliberais dos interesses dominantes da burguesia empresarial (Corporate America), enfraquecimento da função social do Estado e maior participação privada na economia. 
de mão-de-obra como forma de elevar seus salários, com a exclusão de muitos trabalhadores disponíveis na economia. A política sindical formulada por estes sindicalistas consistia em forçar o empregador a contratar somente membros associados do sindicato, mas, por outro lado, dificultavam ao máximo o ingresso de novos membros, com cobrança extorsiva de taxa de inscrição e mensalidades abusivas. Em suma, praticavam a exclusão através de medidas como as que se seguem:

- Apoio às políticas de imigração mais restritivas.

- Diminuição de horas de trabalho diária.

- Desencorajamento do trabalho aos sábados.

- Aposentadoria na data certa, sem extensão de prazo.

- $\quad$ Restrições ao trabalho de menores.

Enfim, todas estas medidas de exclusão visavam ao controle total da oferta daquela mão-de-obra para a qual o sindicato incumbia-se de ministrar cursos de especialização que duravam, em média, duas a três vezes mais do que o tempo necessário.

\section{B. Sindicatos Industriais ou de Firmas (Industrial Unions ou Company Unions)}

Estes sindicatos congregam trabalhadores com um grande número de habilidades e que usualmente estão incluídos dentro de uma mesma indústria ou firma de um distrito industrial.

Atualmente limitado, a priori, a sindicatos locais específicos, demonstrando a tendência mundial, nos países mais industrializados, de convergirem ao que se denomina "sindicato por empresa". 


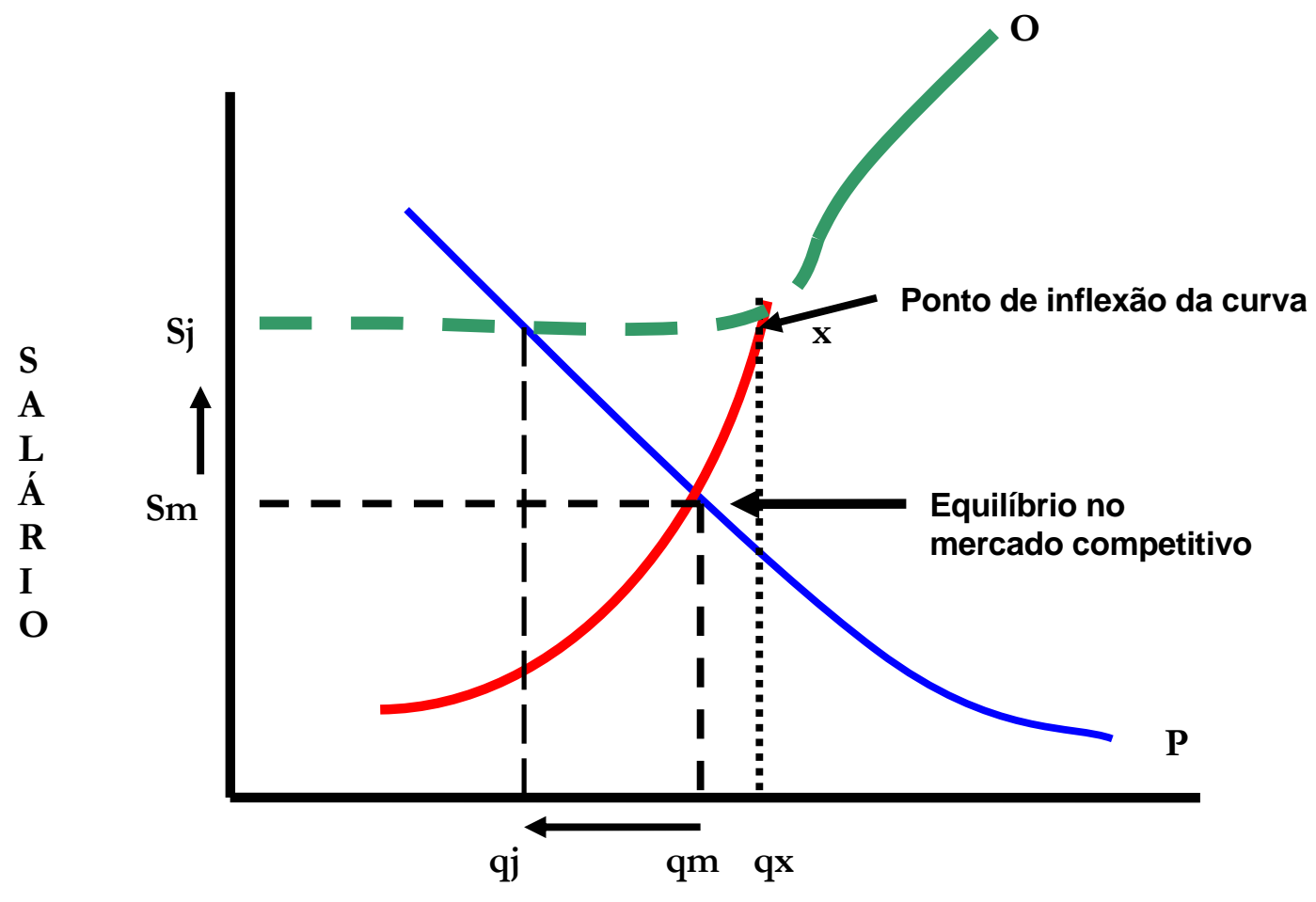

QUANTIDADE DE MÃO-DE-OBRA

Os sindicatos industriais (amplos), ao lutarem por um salário maior ( $\mathrm{Sj}$ ) que o de equilíbrio de mercado $(\mathrm{Sm})$, acabam por restringir, não tão diretamente como o sindicato restritivo, a oferta de mão-de-obra daquele setor específico de mercado (qm > qj). A posição do empresário é muito mais cômoda do que fora nos anos dourados (1945/1975) da economia norte-americana pós-Segunda Guerra Mundial, pois o aparato tecnológico tem facilitado cada vez mais a substituição de mão-de-obra e outros fatores que ele tem a sua disposição na produção transnacionalizada; isto traz conseqüências graves para a manutenção dos postos de trabalho, mas, graças à eficiência de instrumentos protetores do governo norte-americano, eles acabam por compensar a perda momentânea de emprego com instrumentos delineados em seu planejamento estratégico global de oferta condizente com a crescente demanda de mão-de-obra.

Infelizmente, a tentativa por manter o equilíbrio de mercado não é observada nem pelos sindicatos e muito menos pelas empresas ávidas de competirem no desregulado mercado global. 
$\mathrm{Na}$ análise econômica de cálculo da determinante mais incisiva sobre a elasticidade da demanda ${ }^{52}$ de mão-de-obra, o que mais ressalta é a elasticidade da demanda do produto daquele setor industrial e as despesas de salário do pessoal; se a elasticidade do preço for pequena, menor será a perda de empregos.

No caso dos metalúrgicos, tanto faz os norte-americanos de Detroit como os do $\mathrm{ABC}$ paulista no Brasil, onde seus salários médios são os maiores daquele setor em seus países de origem, entretanto a destruição, e mesmo a criação, de postos de trabalhos têm tido características proporcionais diretas ao aumento salarial fazendo com que grandes parcelas de desempregados daquele setor procurem colocações em diferentes áreas ou setores, mas tal fato se permite somente quando a economia está em crescimento real. Fica mais evidente a assertiva quando as empresas fecham e as abrem em outros locais onde os sindicatos não sejam tão fortes nas suas determinações, como são os casos que vêm ocorrendo em diversos países com transferências de mão-de-obra e empresas cuja história tão bem os qualifica.

A diferença entre o "craft" e o "industrial" consiste em:

a. ser o "craft" baseado em habilidade, experiência, (horizontal) por exemplo: o ferramenteiro, carpinteiro, torneiro-mecânico; e "industrial" em diferentes tipos de industrias, (vertical) por exemplo: metalúrgica, têxtil, autos etc.;

b. o alcance do acordo ser diferente em ambos casos, por causa do poder de barganha diferenciado entre os seus contendores;

c. diferentes habilidades e características do emprego. O torneiro-mecânico é muito menos especializado do que o ferramenteiro e, por conseqüência, tem menos poder de barganha;

d. diferente função do líder; o poder de barganha é mais forte, o líder tem mais força política;

e. O "craft" ter estado mais diretamente vinculado à AFL e o "industrial" ao CIO.

\footnotetext{
${ }^{52}$ Mede a relação variacional entre as diferentes quantidades compradas numa unidade de tempo quando ocorre uma variação em um fator, ou do preço da mercadoria, ou da renda, ou do gosto do cidadão, ou de outros fatores, ficando os demais constantes.
} 


\section{Sindicatos profissionais amalgamados (Amalgamated Craft Union)}

O sindicato associa diversas profissões relacionadas. Por exemplo:

Fraternidade Internacional dos Caldeireiros, Construtores de Navios de Ferro, Ferreiros, Forjadores e Ajudantes; ACTWU (Almagamated Clothing and Textile Workers Union); ILGWU (International Ladies Garment Workers Union).

\section{Sindicatos multi-industriais (Multi Industrial Union)}

São sindicatos que combinam diversas indústrias que estão relacionadas, a exemplo de: OCAW (Oil, Chemical and Atomic Workers); UAW (United Auto Workers); URW (United Rubber, Cork, Linoleum and Plastic Workers of America); IBT (International Brotherhood of Teamsters).

Sindicatos profissionais e industriais genuínos são raros nos Estados Unidos. Em vez de seguirem um padrão rigoroso, os sindicatos tendem a se organizar em quaisquer setores que lhes pareçam mais prováveis, no sentido de lhes trazer maior número de membros, realçando sua liberdade de organização.

Tanto a organização horizontal como a vertical tem seus benefícios, dentre os quais podem-se destacar:

- a organização horizontal propicia similaridade de tratamento entre os trabalhadores que desempenham tarefas equivalentes;

- já a organização vertical confere maior força aos sindicatos, pois pode ocorrer a unificação dos mesmos, aumentando-se o seu poder de pressão e negociação;

- a tendência natural de evolução sindical não concebe ingerências externas, nem tampouco imposições legais aos atores interessados quanto ao aspecto de escolha do tipo de sindicato que desejam implementar. 


\subsection{Descrição da organização sindical}

Desde os primórdios da industrialização, as economias têm demonstrado tendência à concentração crescente, característica fundamental do capitalismo racionalista, mas ainda muito insipiente, mas que se devidamente aferido poderia resultar em mudanças que assegurariam sua sustentabilidade efetiva; o que até hoje só lhe assegurou sustentabilidade parcial dada a sua extraordinária capacidade de interação e eficácia, um tanto quanto controvertida. No caso norte-americano, mais da metade da sua força econômica está concentrada em aproximadamente seis centenas ${ }^{53}$ de megacorporações, conquanto sua sustentação financeira seja extremamente complexa e vaga numa rede remota que congrega agremiações sofisticadamente especializadas.

A Associação Nacional de Manufatureiros (National Asssociation of Manufacturers - NAM) congrega a maior parte das indústrias norte-americanas. Megacorporações ligadas ao aço, petróleo, transporte, alta tecnologia entre outros setores, mantêm cada uma seu próprio lóbi que as representa nas instâncias políticas em defesa de seus interesses imediatos.

Os sindicatos norte-americanos têm um quadro similar, pois são organizados livremente, estruturados de maneira descentralizada e em nível federal e revelam poucas camadas hierárquicas. Melhor exemplificando, temos o seguinte quadro:

Nos EUA, os trabalhadores organizam-se em sindicatos locais e estes geralmente localizam-se nos lugares em que as firmas atuam ou representam um grupo especializado (craft) na região. Quase todos os sindicatos locais são afiliados com a grande central sindical nacional, denominada AFL-CIO, que foi o resultado da fusão de duas centrais sindicais em 1955: a American Federation of Labor (AFL) com a Congress Industrial Organization (CIO). A maior parte dos sindicatos são estruturados e organizados em bases de:
a) Uma indústria (Industrial Union). [fase fordista]
b) Uma profissão (Craft Union). [ofício especializado]

\footnotetext{
${ }^{53}$ Forbes Magazine - Who is Who, Abril/2004.
} 
Recentemente (2003), cerca de 80\% (dados são constantemente modificados de acordo com a dinâmica da sua economia) dos sindicatos nacionais ainda eram afiliados com a AFL/CIO (American Federation of Labor / Congress Industrial Organization) que é a única central que os representam em nível federal, demonstrando aqui uma unicidade no topo. Vejamos aqui três exemplos ilustrativos:

1. Os carpinteiros da cidade de Nova Iorque têm o seu sindicato afiliado à AFL/CIO, mas a partir de 2001, quando contavam com cerca de 400.000 membros, foi desligado desta, embora estivessem entre os seus fundadores. Numa leitura posterior deste trabalho, muito provavelmente, o quadro já poderia vir a ser um outro.

2. Os trabalhadores da indústria automobilística da cidade de Chicago têm também seu sindicato local, que também é afiliado à AFL/CIO. Os sindicatos, ditos internacionais nos Estados Unidos, são compostos basicamente de sindicatos locais dos próprios Estados Unidos e do Canadá. ${ }^{54} \mathrm{O}$ Sindicato Internacional dos Madeireiros (The International Woodworkers of América - IWA) é um exemplo clássico de tal afirmativa, pois a localização geográfica parece ter sido um fator de bastante peso para a sua "internacionalização" aqui, no sentido de que congrega trabalhadores da indústria madeireira no norte dos Estados Unidos e no sul do Canadá com interesses comuns. O fator geográfico tem sido cada vez menos considerado, pois com a sua política neoliberal a globalização desconhece "fronteira" e os interesses comuns são os que determinam suas ações.

3. A maioria dos professores, por outro lado, são membros da Associação Nacional de Educação (National Education Association - NEA) que, por sua vez, não são afiliados à $\mathrm{AFL} / \mathrm{CIO}$ e é a maior associação de trabalhadores nos EUA. Esta não foi criada como propriamente um sindicato, mas sim como associação, principalmente em áreas rurais e, destarte, com uma cultura e origem distintas daquelas que formaram a AFT (American Federation of Teachers), esta sim, mais condizente com a estrutura de um sindicato propriamente dito. Apesar dos esforços que vêm sendo desenvolvidos para uma fusão da NEA/AFT, tal intento não tem conseguido uma concretização, principalmente pelos fatos já descritos acima.

\footnotetext{
${ }^{54}$ Talvez seja melhor esclarecer o paradoxo de que "internacional", neste caso, não significa a associação de trabalhadores de vários países, o que talvez, com a globalização econômica, pudesse ser o caminho para o melhor equilíbrio das relações de trabalho nas produções transnacionalizadas que a caracterizam.
} 
A AFL/CIO também mantém escritórios representativos em nível municipal e estadual. Na cidade de Lexington, estado de Kentuky, a maioria dos sindicatos locais é afiliada à AFL-CIO Lexington Kentucky Labor Council (local) e à AFL-CIO Kentucky State (estadual). Estas afiliações são, de qualquer modo, voluntárias e alguns sindicatos locais podem não se juntar a um ou a ambos os grupos. Os sindicatos que não fazem parte da AFL/CIO são o NEA (National Education Association), o UEW (United Eletronics Workers) e o NTEA (National Tresaurer Employees Agency) e, também, até o presente momento (2002), os Carpinteiros (The Carpenters).

Os sindicatos do funcionalismo público, além daqueles dos professores, são: AFSME (American Federation of State, County and Municipal Employees), SEIU (Service Employees International Union) e AFGE (American Federation of Goverment Employees).

O sistema de representação dos trabalhadores (shop steward) nos locais de trabalho tem sido aquele instituído por lei, com representação geral, autônoma e independente dos sindicatos, mas com respeito à atividade sindical nos moldes do direito internacional do trabalho. Isso quer dizer: competência para todos os assuntos ligados direta ou indiretamente aos interesses dos trabalhadores nos locais de trabalho, tendo por composição unicamente os trabalhadores na proporção da força de trabalho, eleitos pelo voto direto dos representados, com atuação singular ou colegiada conforme o tamanho da empresa. Estes têm, então, funções e atribuições de informação, de consulta e de barganhar nos limites estabelecidos pela lei. Negociação do Contrato Coletivo de Trabalho da categoria, com mecanismos internos à disposição dos trabalhadores e dos sindicatos mais representativos, de controle da eleição dos organismos, assim como o respectivo mandato de seus representantes.

Os trabalhadores norte-americanos elegem uma unidade de negociação (bargain unit), mormente, aliados a um sindicato industrial ou profissional, como representante legal para a negociação coletiva (Statutory Bargaining Representative), o que acaba por afetar não só seus afiliados, mas a todos os trabalhadores daquela unidade legal de negociação (Statutory Bargaining Unit). A NLRB superintende a eleição secreta de representante exclusivo da negociação do Contrato Coletivo. Com uma petição de pelo menos 30\% dos empregados daquela unidade, a NLRB autoriza a realização da eleição para que se eleja um representante (individual ou ligado a um sindicato), mas que deverá 
ter, então, no mínimo $50 \%$ dos votos para a sua efetivação. Nas eleições, os trabalhadores têm as opções de vários representantes ou da não representatividade exclusiva.

\section{Gerência do Conflito}

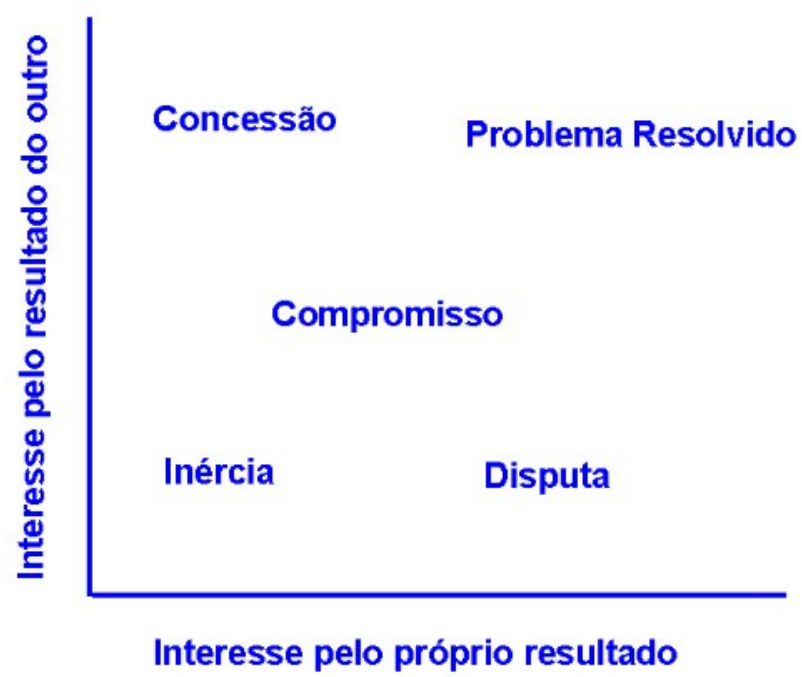




\section{TEORIA DA ATIVIDADE GREVISTA}

Greves devem atuar no sentido de moderar as demandas de ambos os lados.

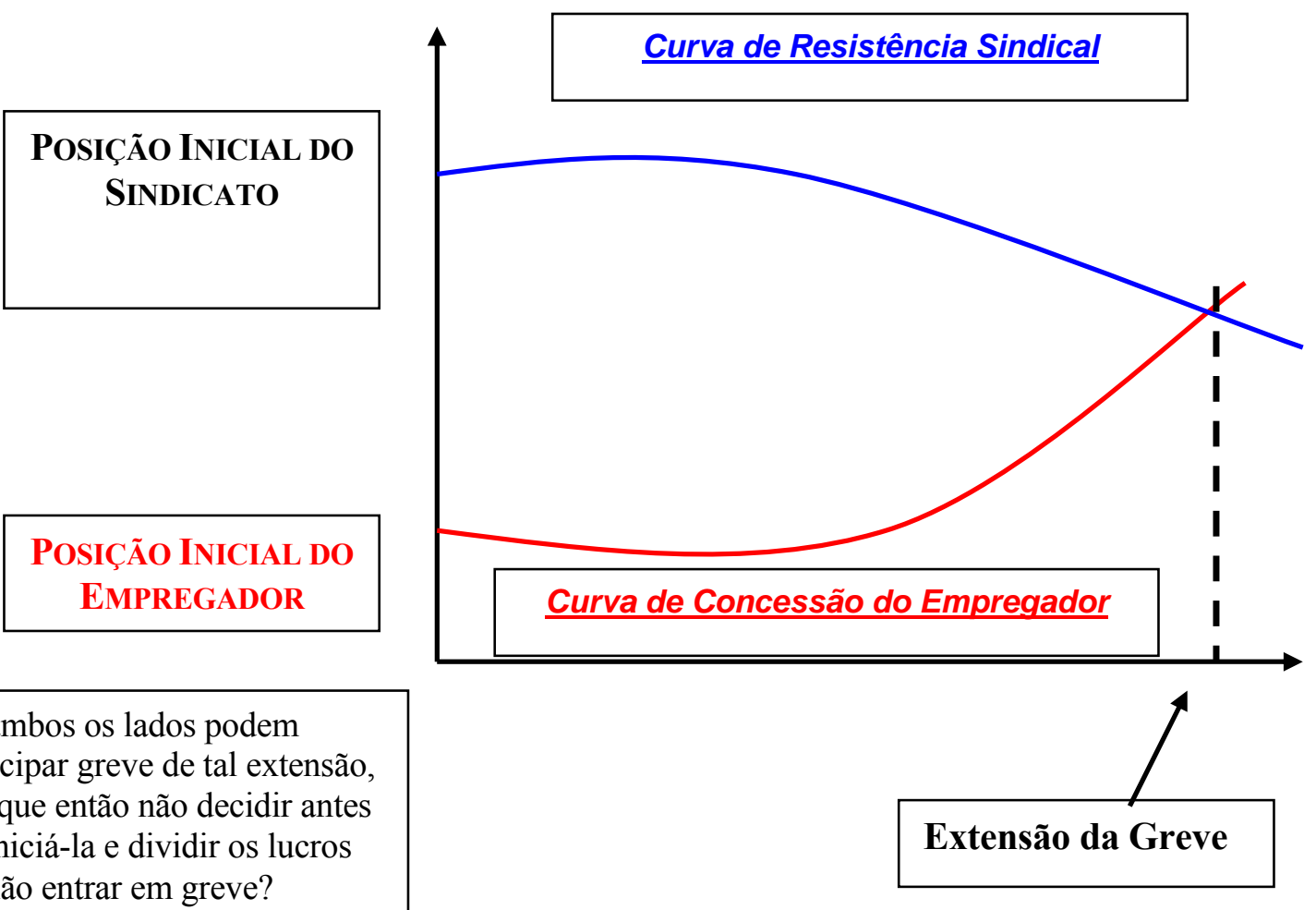




\subsection{A formação de sindicatos trabalhistas (Modus operandi)}

No que se refere ao direito dos empregados para formar sindicatos, nos Estados Unidos, os trabalhadores não têm a garantia de direito constitucional, expressamente, de se associarem. A "National Labor Relations Act" (NLRA) Section 1 [151] é o estatuto que provê a legalidade jurídica necessária pela qual os direitos de associação dos empregados em sindicatos e unidades de negociação são protegidos. A diretriz da lei estatui:

Por meio desta, declaro ser diretriz dos Estados Unidos, eliminar as causas de certas obstruções para o livre fluxo do Comércio e para abrandar e eliminar estas obstruções quando elas ocorrerem no âmbito da prática de conduta da negociação coletiva e proteção do exercício de liberdade total de associação dos trabalhadores, organização própria e a designação de seus representantes de sua livre escolha no propósito de negociar os termos e condições de seus empregos ou outro apoio ou proteção.

Verifica-se que o imperativo desta lei "eliminar as causas de certas obstruções para o livre fluxo do comércio e para abrandar e eliminar estas obstruções...” está contemplada inclusive constitucionalmente e refletem bem a conduta norte-americana de desobstruir quaisquer empecilhos ao livre comércio. Contemporaneamente, tal conduta importante no seu sistema de mercado interno, tem refluído aos mercados internacionais como determinante prioritário ao planejamento estratégico de sua política econômica global. Política bastante adequada no nível que alcançou seu desenvolvimento econômico, e quase sempre inadequada aos países com desenvolvimento aplicado a um capitalismo secundário dependente.

De fato, a política básica da NLRA é a livre escolha do empregado para a formação do sindicato sem que haja qualquer constrangimento de represálias ou punição econômica. A seção 7 [157] da lei estatui:

Os empregados deverão ter o direito de se organizarem, formar, ajuntar ou ajudar as organizações trabalhistas a negociar coletivamente através de seus representantes de sua livre escolha e empenhar de comum acordo atividades para negociarem 
coletivamente ou outra ajuda mútua ou proteção que deverá ter também o direito de se abster desta ou daquelas...

Assim, os principais direitos na Seção 7 são:

- prefaciar a formação de sindicatos entre os empregados de uma firma;

- juntar-se a um sindicato quer seja ele reconhecido ou não pelo empregador;

- ajudar o sindicato a organizar os empregados de uma empresa;

- $\quad$ agir de comum acordo com outros empregados a respeito dos termos e condições do emprego;

- abster-se de qualquer atividade conjunta no interesse ou na ajuda a um sindicato (liberdade total de ação).

A Seção 8 [158] da lei declara ser uma prática trabalhista discriminatória “interferir, restringir ou coagir os direitos garantidos na Seção 7”. O processo de formação dos sindicatos é o assunto tratado na Seção 9 [159]

Nos Estados Unidos, diferentemente do Brasil e México, os sindicatos trabalhistas não estão atrelados implicitamente ao Estado com respeito a sua formação. Os empregadores obrigam-se em reconhecê-los como capacitados a eleger uma unidade de representação exclusiva com poder de barganhar coletivamente. A unidade é eleita pelos próprios trabalhadores e está legalmente sujeita a esta obrigação.

O termo "Organização Trabalhista" é propositalmente definido em termos amplos em ambas leis: National Labor Relation Act (NLRA) e Labor and Management Reporting and Disclosure Act (LMRDA). A formação de organizações trabalhistas é supervisionada pelos 33 escritórios da National Labor Relations Board (NLRB), cuja presidência é nomeada pelo presidente da república após passar por sabatina no Congresso; isto tudo com o intuito de evitar interferência ou restrições indevidas para a sua efetiva formação.

O termo "organização trabalhista" designa uma organização de qualquer espécie, ou qualquer representação; ou, ainda, comitê de empregados, ou planos para sua formação na qual o empregado participa, e que existe com o propósito, em todo ou em parte, para tratar com os empregadores, matérias relacionadas a queixas, disputas trabalhistas, salários, taxas de pagamento, horas e condições de trabalho etc.

A definição da LMRDA é similar e mais abrangente, estatuindo que: 
“Organização Trabalhista” significa uma organização trabalhista engajada em uma indústria que influencia o comércio e inclui qualquer organização de qualquer espécie, qualquer representação ou comitê de representação de empregados, grupo, associação ou planos que estão engajados na participação do empregado e que existe com o propósito, em todo ou em parte, para tratar com os empregadores assuntos a respeito de queixas, disputas, salários, taxas de pagamento, horas ou outros termos, ou condições de emprego, ou qualquer outra deliberação, comitê geral, conselho ou sistema de afiliação ou comitê de afiliação, estão subordinados a organização nacional ou internacional.

Assim, a existência de uma "organização trabalhista" não é de qualquer maneira dependente ou submetida à regulação governamental. Verifica-se a ênfase, como já mencionada acima, do sindicato ou quaisquer outras organizações trabalhistas que possam influenciar o comércio, como a tônica que permeia suas atribuições, desde há muito tempo, inatas no âmago de suas instituições e explicitadas por atribuições genéricas como "market" e "business".

O não reconhecimento voluntário do empregador não invalida tal unidade. $\mathrm{O}$ sindicato deve, então, requerer o reconhecimento do empregador para negociar o contrato como representante exclusivo daquela unidade de empregados específica daquela firma, obtendo o certificado de representante da negociação coletiva daquela unidade através da National Labor Board Relations (NLRB). Para a obtenção de tal certificado, o sindicato propõe uma petição para uma votação secreta entre os empregados daquela unidade, conduzida pelo NLRB e obtendo maioria simples dos votos assegura sua representatividade exclusiva.

São necessários, pelo menos, $30 \%$ dos votos para caracterizar uma demonstração de interesse para assegurar sua representatividade. Tal demonstração de interesse é normalmente submetida à NLRB pelos sindicatos, na forma de cartões individuais que autorizam a consideração de tal petição.

A menos que as partes estipulem a organização da eleição, ou requerida pelos trabalhadores, a NLRB precisa, depois da "averiguação", rejeitar a petição ou ordenar a respectiva eleição. 
$\mathrm{Na}$ maioria dos casos, a averiguação processada pela NLRB consiste na formalização perante um oficial do escritório regional da NLRB onde tal pedido foi solicitado com referência à conveniência do propósito da negociação coletiva, daquela unidade de empregados que declararam na petição e na elegibilidade daqueles empregados ou na classificação destes que votaram na eleição. Assim que a parte é ouvida, o sindicato obtém o certificado da NLRB e o empregador tem a oportunidade de apresentar evidências que pudessem contestar à formação daquela unidade em sua empresa e de discutir sua respectiva posição, atendendo determinações do seu conselho deliberativo.

A NLRB considera a legalidade de tal pedido e determina um veredicto redigindo um documento em conformidade aos precedentes legais:

O Conselho deverá decidir em cada caso, consagrando o direito aos empregados de total liberdade de exercerem seus direitos, se a unidade apropriada para a negociação coletiva será a unidade tal ou...

Uma vez decididas a elegibilidade e a composição da unidade de barganha, a NLRB ou rejeita a petição, se o sindicato se recusa a continuar, ou conduz a uma nova eleição secreta para poder certificar o resultado que agora demanda $50 \%$ dos votos. A lei, Seção 9 [159], provê especificamente que a NLRB deve aplicar as mesmas regras, sem restrições à identidade das pessoas que propõem a petição. Uma vez certificado, o sindicato tem o direito de exigir do empregador seu engajamento nas negociações coletivas de "boa fé" para um contrato dos termos e condições do emprego agora devidamente representado pelos empregados eleitos. A omissão do empregador em reconhecer e negociar com o sindicato, que foi certificado pela NLRB como o representante exclusivo dos empregados daquela unidade, constitui uma prática trabalhista discriminatória, o que é uma violação da Seção 8 da NLRA. Com uma acusação alegando tal violação, o Conselho Geral da NLRB deve processar o empregador.

Em suma, nos Estados Unidos, de modo diferente do Brasil e México, os sindicatos de trabalhadores não precisam requerer autorização do governo ou registro com pré-requisito para a sua formação ou para peticionar uma eleição secreta entre os empregados para representá-los, que após esta eleição de demonstração de interesse será 
conduzida pelo governo federal através da NLRB de modo que seja oficializada a unidade de barganha coletiva. Se eleitos por simples maioria, os empregados, devidamente agrupados, têm o direito de requerer o devido reconhecimento e o poder de negociar um Contrato Coletivo; caso o empregador não o reconheça, deve ser processado pelo governo federal.

No tocante às exigências prescritas nos relatórios (informes), de acordo com as leis norte-americanas, os sindicatos de trabalhadores não necessitam revelar os nomes de seus membros incluindo os direitos de representação dos empregados para a sua barganha coletiva.

Enquanto a LMRDA impõe certas exigências nos relatórios dos sindicatos e que deve ser imposta aos seus membros ou pelo Ministério do Trabalho (Labor Department) através de ação civil, uma possível falha na execução dos ditames nas exigências do relatório, não despojaria os sindicatos do seu direito de solicitar eleições e de obter certificação da NLRB, nem da ação de práticas desleais que, se meritórias, deveriam exigir do Conselho Geral da NLRB, o direito de processar o empregador no sentido da necessidade de reconhecê-los e, assim, poder negociar coletivamente.

Em 1959, foram revogados pela LMRDA os artigos que previam os casos de sindicatos que falhassem no preenchimento legal das exigências ficando assim desprovidos do acesso aos processos da NLRB; casos em que não poderiam ser certificados e nenhuma queixa poderia ser emitida pela NLRB sob acusações formalizadas contra eles. A história da legislação da LMRDA revela as considerações do Relatório do Senado 187 que conduziu a sua cassação.

Negar o acesso dos sindicatos ao Comitê Nacional de Relações do Trabalho (National Labor Relations Board - NLRB), porque seus diretores não preencheriam as informações próprias, é imprudente por várias razões, dentre as quais destaca-se a eficiência no caso de sindicatos fortes, a exemplo do UAW (United Auto Workers), não dependentes dos recursos da NLRB. Não seria justo para os membros que não fizeram nada de errado, mas que sofreriam em ambos os casos a negação de informações e a perda da proteção da NLRB. Os direitos e deveres determinados pela National Labor Relations Act existem para o beneficio do empregado e empregador e, tal obrigação legal, deveria reforçar a igualdade para todos os casos, não jogando as regras de uns contra os outros. A experiência com as cláusulas similares da presente lei mostra claramente que o 
condicionamento do uso de processos da NLRB, conforme as exigências relatadas, possam resultar em frustração do principal propósito do Labor Management Relations Act, ou seja, a determinação de conduzir as disputas trabalhistas de modo eficiente, ordeiro, e de maneira expedita. Ocorre que tal procedimento, quando usado de maneira indevida, "é caro, enfadonho e de eficácia duvidosa".

Os países estabelecem leis e instituições, complexas pela sua natureza multifacetada, pois envolvem os valores econômicos e o poder político, de acordo com suas tradições e costumes, sempre com a finalidade de proteger aqueles que trabalham, procurando dar-lhes uma condição de vida apropriada. O Brasil e México têm suas raízes jurídicas fundamentadas no sistema francês e os USA no sistema inglês. Sem considerar a lei fundamental dos direitos humanos, foram criadas leis trabalhistas básicas para a proteção do emprego individual (CLT no Brasil, Ley del Trabajo no México, NLRA nos USA), que no contexto regulamentam também o acordo coletivo de trabalho e a lei previdenciária que procura assegurar a qualidade de vida. Várias teorias tentam justificar a eficiência dos sistemas, baseadas em como a sociedade manipula tais ferramentas de maneira mais eficiente para assegurar direitos àqueles que dedicaram sua vida ao trabalho consciente e produtivo.

A hipótese da teoria política sustenta que procura influir sobre o melhor desenvolvimento nas relações do capital versus trabalho pela imperfeição de mercado, o que é perfeitamente plausível e correto, entretanto, as supostas correções para ajustar as falhas deste mercado têm sido feitas, não conforme os estritos direitos de quem trabalha, mas sim, de acordo com os interesses particulares. Usam o poder político para suas conveniências às expensas dos trabalhadores conforme os vários casos relatados no presente estudo. 


\subsection{Alguns aspectos do cotidiano dos sindicatos}

A legislação trabalhista norte-americana permite aplicar parâmetros distintos ao julgar os direitos dos empregadores em relação aos empregados. ${ }^{55}$ Em nove de cada dez casos, as eleições dos sindicalistas são acompanhadas de perto pelas gerências das empresas e, obrigatoriamente, de reuniões, a portas fechadas, para desenvolver campanhas injuriantes e agressivas contra as tentativas de formulação da unidade de barganha que se encarregará da negociação coletiva, mesmo a própria formação do sindicato é ameaçada de vários modos. Os supervisores, que não são representados por sindicato algum, são obrigados a participar de campanhas contrárias ao sindicato.

Os trabalhadores que apóiam os sindicatos são prontamente identificados e isolados dos demais trabalhadores. A tentativa de formar um sindicato engaja, em cerca de $80 \%$ dos casos, a contratação de consultores, detetives e empresas de segurança que assessoram os empregadores em campanhas anti-sindicais. As atividades destes incluem a vigilância implícita dos ativistas sindicais com o objetivo de desacreditá-los e, em alguns casos, obtêm antecedentes médicos, penais e financeiros destes, mas também investigam sua vida familiar em busca de algum ponto comprometedor, algo próprio destes "advogados de porta de cadeia" assim alcunhados aqui no Brasil. Salvo raras ocasiões, é negado o acesso ao chão de fábrica ou a qualquer dependência da empresa para que os trabalhadores possam reunir-se durante a hora de descanso e discutir assuntos sindicais.

Os procedimentos da National Labor Relations Board, instituição que regula as relações industriais na maior parte do setor privado, não oferecem um desagravo eficaz frente aos abusos dos empregadores. Os processos judiciais, lentos e ineficazes, fazem muitos trabalhadores desistirem de recorrer a eles. ${ }^{56}$ Um estudo da UAW comprovou que $40 \%$ dos trabalhadores reincorporados realmente voltam ao trabalho e que somente $20 \%$ continuam trabalhando por mais de dois anos, sendo denominada de "tática paulatina

\footnotetext{
${ }^{55}$ Como observado por este autor, durante as suas estadas nos EUA, entre 1980 e 1985 (George Meany Center, vários sindicatos, Labor Department e Bureau of Labor Statistics) e corroborados por pesquisas mais recentes em 2004, durante três meses (Miami, Washington D. C., Nova Iorque, University of Michigan, Chicago, Detroit e Dallas).

${ }^{56}$ São 557 dias (1 ano e meio) em média, (Brasil são 7 anos, ou cerca de 2500 dias), o tempo que a NLRB leva para resolver um caso que transite em julgado, ou seja, encerrando definitivamente o objeto da disputa judicial. Há casos extremos como foi o processo Meritor Bank versus Vinson que ficou tramitando nos tribunais federais por 14 anos e acabou tendo sido declarada a falência da empresa mesmo antes do final do processo!
} 
desamparadora" com a exclusão dos elementos que lutam verdadeiramente pela melhoria da condição dos trabalhadores.

Ainda que ilegalmente, alguns empregadores ameaçam mudar as fábricas em mais da metade das campanhas de sindicalização, segundo um estudo publicado em 1996 pela UAW (United Auto Workers) em que se comprova, tal assertiva; problemas deste tipo são enfrentados por vários sindicatos de outros setores, mormente por aqueles sindicatos que representam trabalhadores de uso intensivo de mão-de-obra cuja produção transnacionalizada destrói empregos locais e os transferem alhures onde as condições de precariedade das relações de trabalho são determinantes. As ameaças têm sido mais incisivas nas indústrias metalúrgicas, pois nestas a resistência aos direitos ocorre em mais de $60 \%$ dos casos; aqui existe um paradoxo, pois vai contra a famosa liberdade de organização tão bem propalada pela verdadeira democracia e que merece uma investigação mais criteriosa quanto aos fundamentos teóricos para tal asseveração, a começar pelo não reconhecimento da convenção 87 da OIT.

Aproximadamente $30 \%$ dos empregadores ameaçam fechar suas fábricas e cerca de 14\% cumprem-nas quando os Contratos Coletivos do Trabalho são barganhados em primeira mão.

Um estudo bastante detalhado entre 600 empresas efetuado pela "Cornell University" evidenciou que, em $62 \%$ dos casos, os empregadores fazem sérias ameaças de transferir-se para outros países onde salários e benefícios são menores e cuja legislação ambiental, apesar de ser devidamente considerada, não é cumprida de modo a coibir possíveis infratores dada a precariedade dos mecanismos de coerção. A NLRB exige que se obtenha um mandado judicial federal contra os sindicatos que realizam práticas trabalhistas discriminatórias. Entretanto, não existe uma obrigação equivalente quando os empregadores realizam, mormente à socapa, aquelas práticas trabalhistas discriminatórias sob a tradicional alegação de obstrução aos negócios.

As medidas discriminatórias dos empregadores, freqüentemente, são cumpridas antes que se concluam quaisquer procedimentos legais. A excessiva demora e os custos elevados implicados na organização de sindicatos determinam, na prática, a negação implícita a amplos segmentos da mão-de-obra norte-americana não elitizada pelo direito de sindicalização e, por conseguinte, restringem o seu direito à livre negociação coletiva ao tentarem impedir a formulação da unidade de barganha. 
A certificação não representa um limite para as possibilidades de que dispõem os empregadores para desencorajar os trabalhadores a exercerem seus direitos sindicais. Os sindicatos novatos são os que mais padecem nas mãos de firmas que usam em suas negociações a má fé e se calcula que, cerca de 35\% dos casos, envolviam práticas discriminatórias e, destarte, cerca de $40 \%$ das negociações deste primeiro contrato negociado fracassava e 1/4 não conseguia negociar nenhum contrato posterior.

A própria legislação imbuída em desobstruir quaisquer obstáculos que dificultem o livre comércio e várias outras resoluções administrativas opõe toda uma variedade de restrições à participação dos trabalhadores em alguma forma de solidariedade, com delimitações sobre greves ocasionais, recusa coletiva de trabalho e inibição de transações. Entretanto, a lei outorga aos empregadores o livre jogo das forças econômicas e se eles não obtêm o planejado através das negociações coletivas, usam todos os tipos de tergiversação, como foi o caso, em 5 de fevereiro de 1996, da Crown Central Petroleum, sediada no Texas, responsável por uma das maiores greves patronais da história dos EUA, que acabou por impor unilateralmente, em 1999, seus termos de fechar a fábrica e transferir os empregados para outro local.

A inserção estratégica da indústria do petróleo, como gestora de grandes lucros, tem um histórico desalentador pela defesa intransigente de seus interesses em relação aos direitos dos trabalhadores nas negociações coletivas do trabalho. Outro destaque destas indústrias tem sido suas negociatas com países que abusam, notoriamente, dos direitos humanos, trabalhistas e ambientais. Em outro caso ocorrido em 1999, os trabalhadores do sindicato dos eletricitários (International Brotherhood of Electrical Workers), no "Local Union 1510", denunciaram várias irregularidades contra a fábrica Hi-Tech Cable Corporation, no estado de Mississipi, e continuaram trabalhando sem contrato coletivo, sendo que a empresa compradora em 1992, a Southwire, que se tornou sua subsidiária, declarou que a negociação coletiva estava num ponto morto ao terminar o prazo do contrato anterior e aplicou, unilateralmente, mudanças nas condições de emprego, incluindo jornadas de "12 horas sem horas-extras e a eliminação da arbitragem obrigatória com a intenção clara e deliberada de destruir o sindicato". 57

Dentre fatos mais recentes, ocorridos em 2001, de táticas similares, destaca-se o caso da firma chamada Avaya Corporation, que fora uma subsidiária da American

\footnotetext{
${ }^{57}$ In: Annual Survey of Violations of Trade Unions Rights. International Confederation of Free Trade Unions (ICFTU), 2001.
} 
Telephone \& Telegraph (AT\&T), que teve parte vendida a uma fábrica chamada Celestica Corporation, não-sindicalizada. Em mais de 30 anos de operação no mercado, esta corporação mudou de nome várias vezes:

1. WESTERN ELECTRIC, subsidiária da AT\&T;

2. AT\&T;

3. LUCENT CORPORATION, em 1996;

4. Celestica Corporation, em 2000;

5. AVAYA CORPORATION, em 2000.

O sindicato dos eletricitários que representava os trabalhadores da empresa Avaya Corporation, The International Brotherhood of Electrical Workers (IBEW), já estava consolidado há mais de 30 anos e havia acertado um "Contrato Coletivo", devidamente ajustado e assinado. A Celestica Corporation construiu na parte vendida da Avaya Corporation um muro no meio do prédio, dividindo a fábrica entre o departamento de engenharia e o departamento de desenvolvimento de produto que ficou com a Avaya Corporation.

A nova Celestica Corporation minimizou as preocupações dos trabalhadores com a assinatura de um novo Contrato Coletivo que, contudo, retirava quase todos os benefícios, inclusive o programa de assistência e acordos sobre regras de trabalho, pelos quais tinham lutado por cerca de 30 anos, conservando apenas o salário e os dias de férias acertados em Contrato Coletivo anterior. A nova empresa alegou que deveria começar do marco zero e, para esta finalidade, estipulou um trabalho de condicionamento instrumental, valorizando seus planos e objetivos, com a utilização de forte aparato midiático. Aquilo que a princípio parecia não ser tão ruim, no final revelou-se uma falácia, pois resultou em perdas de empregos e danos morais. Teve papel preponderante nestas discussões o forte Sindicato dos Engenheiros que, mais capacitados nas negociações, não esmaeceram com as tentativas da gerência em subtrair parte significativa dos benefícios adicionais que já haviam sido conquistados (fringle benefits).

Os produtos desta fábrica eram sistemas de telefone PABX instalados em gabinetes cujos tamanhos variavam do de um forno de micro-ondas ao de um refrigerador. Uma parte da fábrica produzia os circuitos integrados, enquanto a outra parte montava, configurava os circuitos nos gabinetes, testava e embalava para estocagem e 
carregamento. Durante mais de 30 anos, com poucos trabalhadores contratados devido ao que os americanos chamam de "attrition forecast" (antecipação, na base de planejamento estratégico, de prever quando ocorrerão vagas de emprego), teve como resultado a força de trabalho diminuída, cujo ápice atingira 3500 e baixara para 900. O sistema anterior de produção era moderno, eficiente e criador de trabalho humano, mas a concorrência irracional e cega que vem comandando a nova economia, paulatinamente, vai conduzindo-a a uma tendência diminutiva de sustentabilidade.

A transferência para a Celestica Corporation dos produtos da Avaya Corporation exigia reengenharia completa. Os trabalhadores da Avaya Corporation foram convocados para dar assistência aos novos times de engenheiros para a conversão dos processos, trabalhando em turnos de 10 horas, 7 dias por semana com a alegação de pedido urgente. Três faltas, mesmo ocorridas em fins-de-semana, significavam demissão. O limite federal, para casos especiais, de 14 dias contínuos de trabalho, era cumprido à risca pela direção da empresa assessorada por notáveis advogados especialistas.

A contratação de trabalhadores temporários, mais jovens, para a montagem das peças tinha sido efetivada, mas o contrato assinado anteriormente com os trabalhadores sindicalizados previa que os temporários seriam dispensados primeiro, antes dos permanentes. A tática usada pelas corporações tem sido a seguinte: dispensam os operários na quinta-feira e lhes é dito para não aparecerem na sexta-feira, sendo que os recontratavam na segunda-feira seguinte. No final da estória, a unidade de produção foi totalmente transferida para três destinos:

- $\quad$ Para o local próximo nos EUA, sem sindicatos.

- Maquiladoras no México, sem sindicatos ou submissos.

- $\quad$ E, para diversos locais na Ásia, sem sindicatos.

A política da doutrina do portão separado (Separate Gate Doctrine) foi um fortalecimento da lei Taft-Hartley, quanto aos boicotes e piquetes de efeitos secundários, preceituado pela Suprema Corte. Muito comum no setor da construção civil, onde se misturam vários prestadores de serviços e fornecedores, mas tem servido de modelo para outras áreas de produção. A NLRB preceitua que os sindicatos têm o direito de promover piquetes primários, ou seja, somente aqueles com quem estão em disputa. Por exemplo, se acontecer uma greve contra a firma contratante e existir somente um portão, o piquete é 
legal e quaisquer efeitos secundários na outra firma contratante não a deslegitima. Se a empresa construtora tiver dois portões, um restrito aos seus empregados e o outro ao seu fornecedor que, na prática, acaba por restringir a todos, então, tem sido motivo de muitas controvérsias ao ser considerado ilegal. Prática muito comum em meados dos anos 70 do século passado e têm sido em vão os esforços de tentar emendá-la a favor dos sindicatos de trabalhadores.

Estas circunstâncias oportunas resultam sempre de perspectivas de mercado, cujas vendas ou fusões de corporações determinam o embate complexo no mundo transglobalizado, pois a competitividade é condição sine qua non de sobrevivência. Infelizmente, as corporações têm tido a predisposição de destruir a força sindical, de maneira a retirar-lhe o status com a conseqüente desistência dos trabalhadores induzidos por pressão. Tais fatos trazem no íntimo de suas asserções, o tradicional conflito do capital versus trabalho, quando a premência da preponderante acumulação capitalista enfrenta as tentativas de fortalecimento dos sindicatos de trabalhadores na perspectiva de transnacionalidade produtiva, que caracteriza a época contemporânea neoliberal.

A AFL-CIO enviou uma carta solidária ao representante do sindicato, evidenciando um olhar bastante restrito quando não tenta mudar os termos que garantiriam aos trabalhadores sindicalizados, por meio de algumas das decisões de uma maneira mais efetiva, os seus direitos tão arduamente conquistados, compensando as decisões particulares excludentes do enfoque transcorporativo. $\mathrm{O}$ governo norteamericano procura compensar as derrotas dos sindicalistas com uma série de benefícios, mas, se as condições continuarem a se agravar de modo progressivo, poder-se-ia assistir ao fortalecimento de sindicatos socialistas mais ligados à valorização dos trabalhadores que vem se deteriorando, em detrimento dos interesses do capital, cujos compromissos são alheios aos anseios do árduo trabalho por aqueles efetuado.

Fatos anteriores têm demonstrado que estas táticas são comuns, pois como resultado da execução da lei Sherman Antitrust Act, em processo contra a AT\&T em 1974, foi interrompido seu monopólio com a renúncia dos serviços de telefonia de curta distância. Também foram criadas 7 companhias que vieram a ser chamadas de "Baby Bells", que proveram os serviços de curta distância, ficando com a AT\&T apenas os de longa-distância. Com o passar do tempo, muitas destas novas companhias entraram em processo de fusão, com aprovação do Departamento de Justiça, reagrupando as forças 
monopolísticas do setor. Fato curioso é que, mais recentemente, suas subsidiárias e outras corporações concorrentes do ramo de prestação de serviços exclusivos em países menos desenvolvidos, têm voltado seus ataques dissimulados aos próprios clientes, como provado pelas estatísticas alarmantes dos centros de proteção aos consumidores. Estas procuram se amparar em casuísmos legais, mormente em ambientes de incorporações, fusões ou venda dentro de países com legislações diversas, pois se valem de má-fé no que diz respeito à interpretação dos direitos trabalhistas e ambientais.

Em 1999, a multinacional francesa Imerys (resultado da fusão da Imetal e English China Clays), do ramo de cerâmica e produção de materiais de construção, retirou a representação sindical dos seus trabalhadores por causa da fusão desta empresa com outra não-sindicalizada, que empregava um maior número de trabalhadores. Os sindicatos que representavam os trabalhadores da English China Clay eram "U. S. Paper, AlliedIndustrial, Chemical \& Energy Worker's Unions (PACE)" até a momento da fusão, quando a firma retratou o reconhecimento sindical numa afronta aos estatutos laborais norte-americanos. A empresa iniciou uma campanha anti-sindical pautada em reuniões obrigatórias, cujos supervisores desta fábrica e de outras três não-sindicalizadas empregavam táticas de intimidação.

Como sói acontecer, os conglomerados que incorporam empresas de diversas atividades, aproveitam-se destas situações inusitadas e ainda não devidamente previstas pelas normas, para pôr em ação práticas discriminatórias deveras injustas e muitas vezes desleais, pois com a legalidade ainda difusa, os compromissos já negociados num contrato anterior estariam supostamente sub judice e o tempo para arregimentar novas estratégias já vem sendo considerado uma vitória para as corporações mais identificadas com a política neoliberal. Aquelas práticas que não são toleradas na Europa vêm caracterizar o tipo de política adotada por empresas transnacionais alhures e sinalizam as poucas diferenças nas dispensas arbitrárias entre o modelo europeu e o norte-americano fora de seus respectivos territórios geográficos.

As empresas de construção civil - usualmente cooptadas e com negociações pendentes anteriormente - mostram que $80 \%$ dos trabalhadores substituídos não conseguem um contrato justo, pois, segundo a lei, os empregadores podem contratar empregados substitutos durante uma greve de matiz econômica, ainda que a dispensa dos 
grevistas fosse proibida, mas o uso de substitutos permanentes faz com que, na prática, seja impossível distingui-los dos dispensados.

Cada vez mais, são os empregadores que provocam deliberadamente greves, com o intuito de eliminar os sindicatos, reafirmando a prepotência do capital sobre os trabalhadores. A estratégia usada é esta: os trabalhadores de substituição permanente têm o direito de votar a fim de retirar a personalidade jurídica do sindicato, eliminando, assim, seu reconhecimento sindical. O "jeitinho norte-americano", diferente do "jeitinho brasileiro", é muito mais sutil e sofisticado, pois está inserido dentro de uma rede complexa que envolve centenas de entidades especializadas e supervisionadas por uma diretriz de planejamento estratégico global.

A última grande alteração no direito sindical norte-americano foi processada pela Labor Management Reporting and Disclosure Act, também denominada "LandrumGriffin Act". A referida lei articulou-se em dois perfis específicos de tutela e de intervenção:

- em uma parte, disciplina a posição e os direitos dos associados em relação aos sindicatos quanto ao direito de receber informações (Bill of Rights);

- em outra parte, prescreve uma complexa norma disciplinando a estrutura e a atividade da associação sindical como a elaboração de estatutos e registro dos sindicatos, informações sobre as finanças pessoais dos dirigentes, informações dos empregadores sobre eventuais empréstimos feitos a sindicatos ou dirigentes etc.

No Brasil não houve grande impacto, pois os trabalhadores das empresas "fundidas" estão sob a guarda de um mesmo sindicato, sendo que o mesmo ocorre do ponto de vista da representação empresarial, entretanto, a lei sempre é mais favorável ao empregado, sustentando a premissa do direito do trabalho de proteger o menos favorecido, ou seja, o hipossuficiente.

As leis federais norte-americanas dão aos sindicatos certos direitos. A Comissão Nacional de Relações do Trabalho (National Labor Relations Board - NLRB) controla estas leis. Os Estados, através de seu poder legislativo e assessorados por advogados de alto gabarito quanto às reformulações de leis acabam por interferir nas relações trabalhistas, historicamente, sempre menos favoráveis aos empregados, mormente e muito mais, aos que não estão devidamente organizados. Faz parte da própria essência do poder 
interno norte-americano a intransigência àqueles que dificultam o livre jogo do comércio, pois o capitalismo mais avançado consiste numa acumulação muito exacerbada o que tem dado sustentação ao seu vasto império. ${ }^{58}$ Desde muito cedo, o povo norte-americano competindo entre si em larga escala tem favorecido o esmorecimento de aspectos humanitários, importantes para seu próprio bem-estar. A racionalidade de tal competição traz-lhe frutos econômicos que, destituídos de sapiência, provocam o desequilíbrio que começa no próprio lar, refluindo, às vezes, de maneira imperceptível, aos diversos setores da sua sociedade. A alienação mental nos EUA foi estimada em $22,1 \%$ da população, maiores de 18 anos de idade, ou seja, 1 em cada 5 sofre de alguma espécie de desarranjo mental. ${ }^{59}$ Essa alienação é crescente e caracteriza o alheamento com que o governo conduz a sociedade para aspectos mais humanitários.

As leis federais são bastante complexas, pois estão ligadas a vários dispositivos que envolvem, entre outras coisas, prioridade para certos segmentos de segurança nacional. O próprio Contrato Coletivo de Trabalho estabelece a sua duração (geralmente 1 a 3 anos), bem como as condições, a remuneração e as horas de trabalho. O sindicato local que se denomina Local X é afiliado ao International Longshore and Warehouse Union (ILWU) localizado no estado da Califórnia. A ILWU ajuda os sindicatos locais de maneiras bastante diversas, sendo a mais importante a de ajuda política, mas também os auxilia durante as negociações propriamente ditas e provê a educação quando preciso, a ILWU é, por sua vez, afiliada à AFL-CIO.

\footnotetext{
58 A acumulação sempre caracterizou o capitalismo, mas vem se intensificando nas mãos de poucos em função rentista em detrimento aos investimentos que dêem sustentação à própria economia, que tem tido como resultado uma maior precarização social e ambiental. No caso contemporâneo brasileiro, os aproximadamente 20.000 novos milionários são frutos, principalmente, desta função rentista.

59 AMERICAN PSYCHIATRIC ASSOCIATION. Diagnostic and Statistical Manual on Mental Disorders, 4th edition, (DSM-IV). Washington, D. C.: American Psychiatric Press, 1994.
} 


\subsection{O crime organizado e suas relações com as empresas e os trabalhadores organizados em sindicatos}

Uma parte importante da história dos sindicatos norte-americanos está ligada aos impactos evasivos que a extorsão do crime organizado, em especial, a máfia ítaloamericana, tem efetuado junto às diversas instituições industriais, comerciais e, em especial, de trabalhadores organizados em sindicatos.

A prática extorsiva possui como antecedente amplamente conhecido o feudalismo com a cobrança excessiva de taxas. São diversos os aspectos que justificam as peculiaridades da máfia siciliana, na Itália:

1. sua posição estratégica entre a Europa, África e Oriente Médio, que foi palco de insidiosos infortúnios, graças às ambições desmedidas de toda a sorte de conquistadores que por lá transitaram;

2. culturalmente diferente da Itália, a Sicília tem sido bastante tradicional e essencialmente familiar, tendo sofrido uma maior influência dos gregos e caracterizada como uma sociedade muito sofrida, mas de grande capacidade perceptiva;

3. um total descrédito popular na execução de leis na dinastia dos Bourbons, através de Carlos III, Duque de Parma e filho de Felipe V, que, em 1734 conquistara o reino de Nápoles-Sicilia;

4. a invasão de Napoleão Bonaparte (1796/97), que deixou a Sicília uma terra desamparada onde reinou o banditismo e a desordem. Neste clima, a disposição da ordem pública foi deixada ao povo siciliano que formou júris populares, sem o uso de normas específicas que pudessem promover a justiça, nada disto tendo ido além de mera reação aos excessos do feudalismo e absolutismo intransigentes. Tais júris populares deram suporte à formação das bases em que a máfia tradicional tem atuado e se desenvolvido.

O crime organizado ítalo-americano, denominado "La Cosa Nostra" iniciou seu poderoso desenvolvimento, a partir da segunda metade do século XIX, com a chegada dos primeiros mafiosos imigrados da Sicília, após campanha do governo italiano contra a Máfia, entre 1877-1878. Vale ressaltar que as autoridades italianas, entre 1923 e 1934 , 
perseguiram intensivamente e condenaram mais de 1200 membros da máfia siciliana justamente no momento em que a máfia ítalo-americana florescia em poder, fato que determina um grande inter-relacionamento entre a máfia siciliana e a norte-americana.

O crime organizado desenvolvia-se com uma série de transformações através do banditismo, pois no início do século passado, a cidade de Chicago, tradicionalmente violenta e corrupta, tinha mais assassinatos do que Nova Iorque e Londres juntas. Os criminosos dificilmente eram presos e somente 3,3\% dos suspeitos eram julgados e colocados em prisão. Cultivara-se um verdadeiro cartel em que os profissionais do crime corrompiam a polícia, políticos e advogados. O desenvolvimento do crime organizado prosseguia de modo mais intensivo, como conseqüência da crise de 1929, com a máfia ítalo-americana agindo com mais vigor até por volta de 1970.

Numa visão mais ampla, a inter-relação do crime organizado em Chicago e Nova Iorque - cidades pujantes que se sobressaem na representação dos sindicatos e do crime organizado -, com as instituições trabalhistas e empresas é de fundamental importância para se compreender a evolução histórica mais recente dos movimentos trabalhistas, interagindo e inspirando os conceitos e o modus operandi que derivaram do pensamento elitista dominante e que, certamente, carregam no âmago de suas asserções, os fundamentos políticos, econômicos e sociais que impactaram, negativamente, não só as relações econômicas de trabalho, mas toda uma sociedade.

A prática do crime organizado em fornecer "indivíduos encarregados da vigilância na manutenção dos seus interesses" para aterrorizar operários nos conflitos trabalhistas, sobrepujava quaisquer tentativas de negociação de um Contrato Coletivo de Trabalho que fosse mais justo. Está profundamente arraigado na mentalidade norteamericana o problema do socialismo e do comunismo e do que eles representam para o sistema capitalista, pois, em vez de dialogarem com os socialistas, os empregadores preferiam entabular acordos com o crime organizado que tem como princípio o lucro particular e o poder pessoal e familiar. Com o apoio, o controle e a proteção do crime organizado, os empregadores formavam associações cujos objetivos eram:

- Limitar e prevenir a competição.

- Fixar preços.

- Alocar contratos.

- Formar cartéis. 
- Controlar os sindicatos dos trabalhadores.

- Formar lóbis no Congresso.

De acordo com o relatório "The Edge", de 1986, que investiga o crime organizado, dentre os inúmeros sindicatos controlados pelo mesmo, destacam-se os sindicatos internacionais, ou seja, sindicatos norte-americanos que se associam a sindicatos canadenses, como os seguintes:

- International Longshoremen's Union - ILA (estivadores);

- Laborers International Union of America - LIUNA (trabalhadores diversos, geralmente imigrantes, mormente ligados à construção civil);

- International Brotherhood of Teamsters - IBT (caminhoneiros, motoristas);

- Hotel and Restaurant Workers International Union - HEREIU (garçons, cozinheiros).

A emenda constitucional americana de 1920 que proibira o transporte, venda e fabricação de bebidas alcoólicas - também conhecida por "lei seca" - e que vigorou até 1933, teve papel preponderante na formação histórica das inter-relações destes sindicatos junto às atividades do crime organizado em suas negociatas, ou seja, serviços de estivagem, pois as bebidas alcoólicas eram produzidas no Canadá, mormente junto aos grandes lagos fronteiriços (ILA), trabalhadores para a produção (LIUNA), distribuição do produto nos estabelecimentos (IBT) e serviços em hotéis, bares e restaurantes (HEREIU).

Os métodos usados são os da máfia ${ }^{60}$ siciliana em defesa de seus interesses privados e controle de diversas atividades e se tornou exemplo sem paralelo por diferenciar-se de outros grupos de crime organizado, no uso extensivo da extorsão nas relações trabalhistas do Contrato Coletivo de Trabalho, destacando-se na distinção aos outros grupos que atuavam somente nas atividades específicas do submundo do crime.

A lei seca tornou "La Cosa Nostra" rica e poderosa, sendo que após a revogação da dita emenda constitucional, com a liberação das bebidas alcoólicas, a extorsão trabalhista tornou-se o carro chefe de suas atividades ilícitas cujo ápice deu-se entre 1950 e 1960, época em que havia pelo menos uns vinte "Capo de tutti capi", 61 interagindo nas

\footnotetext{
${ }^{60}$ Que no dialeto siciliano significa "macho", "viril".

${ }^{61}$ Dentre os chefes das famílias independentes, havia um que era o patrão de todos.
} 
principais cidades. $\mathrm{O}$ dinheiro que obteriam, em grande parte, advinha da extorsão aos Contratos Coletivos de Trabalho barganhados de forma intimidante e violenta, transformando este instrumento legítimo dos trabalhadores em mera aceitação daquilo tido por "justo", que os empregadores em conluio com o crime organizado tinham a oferecer.

O movimento sindical clássico estava vivendo seu momento de esplendor com a economia desenvolvendo-se e o número de sindicalistas crescendo e com os Contratos Coletivos de Trabalho sendo negociados, exemplarmente, a favor dos empregados. As perspectivas estratégicas do crime organizado eram aquelas ferramentas tradicionais de intimidação, suborno e violência que descaracterizavam os Contratos Coletivos de Trabalho tidos como justos. Os membros do "sindicato do crime" fizeram parte de inúmeras diretorias de diversos sindicatos dos trabalhadores, uma vez que para a concretização de grandes negócios exigia-se a aliança das "máquinas" do crime organizado, dos sindicatos de trabalhadores e de algum partido político, principalmente o mais progressista.

As empresas empregavam os gângsteres com o título de "Consultores Trabalhistas", bem ao contrário dos modernos consultores de empresas especializados em resolverem quaisquer tipos de problemas trabalhistas sem o uso de instrumentos de intimidação tão violentos. Todos estes acontecimentos provocaram um descrédito nos sindicatos de trabalhadores e, atualmente, a falta de perspectiva tem provocado desalento na participação de novos correligionários, principalmente os mais jovens.

A grande central trabalhista AFL (American Federation of Labor) tentou em 1950, de maneira muito vaga e equívoca, abrandar a corrupção e extorsão feita aos sindicatos de trabalhadores justamente no momento em que as condições políticoeconômicas faziam o país desenvolver-se com crescimento em todos os setores. Desde esta tentativa infrutífera, a tendência do movimento trabalhista tem se eximido em admitir ou mesmo em tentar sanar a cumplicidade com o crime organizado, o que tem causado danos, principalmente aos trabalhadores minoritários que lutam pela melhoria de suas condições sociais.

Corroborando as conclusões de vários estudiosos do assunto, as evidências têm mostrado que os sindicatos opuseram-se à lei "Landrum-Griffin" (que dava aos membros dos sindicatos o direito de questionar seus representantes e exigia o balanço contábil 
financeiro de suas atividades de acordo com as normas contábeis do $\mathrm{AICPA}^{62}$ ) e à formação, junto ao Ministério do Trabalho (Labor Department), de uma repartição especializada na investigação da extorsão feita aos trabalhadores e, após 1970, ao uso da lei R.I.C.O, ${ }^{63}$ o que tem evidenciado a força do crime organizado em conduzir os caminhos a que os sindicatos são obrigados a submeter-se.

A lei R.I.C.O. tornou-se efetiva em 1970 com o objetivo principal de eliminar a Máfia e outras organizações criminosas, sem estar, contudo, diretamente voltada para o sindicato de trabalhadores, mas as conexões estavam tão evidentes que acabavam por incriminá-lo. Por conseguinte, as investigações nos sindicatos envolvidos tornaram-se rotina e focaram uma série de atos ilícitos, entre os quais a extorsão e a infiltração, inquirições sobre empréstimos em quantidade maior do que a usual ou a necessária e fraudes nas aplicações financeiras do montante considerável dos fundos sindicais.

\section{PROCEDIMENTOS DA QUEIXA CONTRA A LEI R.I.C.O.}

É indeclinável que cada queixa baseie-se em violação criminal e/ou extorsão monetária. Em matéria cível, o demandante precisa justificar não só o engajamento naqueles atos, mas em uma série que possa caracterizar a constituição de um padrão.

Os procedimentos cíveis e/ou criminais são bastante diferentes no rol das evidências:

- Em matéria cível, o querelante precisa apenas convencer o júri das evidências do ato extorsivo que o réu poderia ter cometido. Em matéria criminal, o querelante precisa provar o exercício de atos extorsivos monetários perante as possíveis dúvidas do júri.

As penalidades são diferentes também:

- Em matéria cível, a sentença determina o montante de três vezes o prejuízo referenciado no julgamento, mais os honorários e custos advocatícios.

- Em matéria criminal, o réu vai para a cadeia.

\footnotetext{
${ }^{62}$ American Institute of Certified Public Accountants. No Brasil, Conselho Federal de Contabilidade.

${ }^{63}$ Racketter Influenced and Corrupt Organizations Act (R.I.C.O.); essa lei resulta da reforma da lei Hobb de 1946 (Hobb's Act).
} 
A partir de 1981, essa lei efetivou-se de maneira mais incidente sobre as corporações, em razão da similaridade das práticas destas com as mafiosas.

Um exemplo clássico deste momento decisivo na execução da lei R.I.C.O. foi o assassinato em 1975 do conservador Jimmy Hoffa (que tinha ligações com líderes do crime organizado) quando tentara a reeleição à presidência do Sindicato dos Motoristas (International Brotherhood of Teamsters - IBT), sinalizando que o crime organizado não permitiria que se elegesse a cargo diretivo nos diversos sindicatos qualquer pessoa que não seguisse seus mandamentos. Após exaustivos anos de investigação, ficou muito claro à polícia federal (FBI) que foi a interligação dos chefes mafiosos da cidade de Chicago com o presidente do sindicato dos motoristas de New Jersey a responsável pelo assassinato, pois todos os demais que ousaram questionar as atitudes dos mafiosos eram sumariamente eliminados. Este escândalo deixou marcas no sindicato até os dias de hoje, o que explica, em parte, a preocupação de evitar publicidade deletéria e, algumas vezes, a confrontação com os empregadores.

A idéia enfática de como o crime organizado manipulava os contratos coletivos de trabalho origina-se da observância dos falseamentos dos acordos coletivos que se denominavam "sweetheart" (literalmente: coração doce, mas com significado figurado de “meu bem, meu amor"), ou seja, contrato particular arranjado pelo empregador para seu próprio benefício e comumente prejudicial aos interesses autênticos dos trabalhadores. Sobressai-se, destarte, a figura dos dirigentes sindicais eleitos para a unidade de barganha em conluio com o crime organizado na efetivação dos contratos coletivos em detrimento dos próprios trabalhadores.

Mesmo através da lei R.I.C.O. a justiça tem se mostrado lenta e ineficaz nos processos envolvendo a máfia, o que ainda reforça a influência política e domínio latente desta última, pois, entre outros casos, o processo contra o Sindicato Internacional dos Motoristas (International Brotherhood of Teamsters - IBT), de 1989, não foi suficiente, nem mesmo depois que a maioria do Congresso norte-americano peticionou o seu não arquivamento, com o objetivo de conservá-lo juridicamente relevante, com a tradicional alegação de que um interventor, nomeado pelo governo para administrar o sindicato de trabalhadores, tira-lhe a competência para se fazer representar!

Entretanto, a partir de 2003, foi consentida a nomeação de interventores para os 4 grandes sindicatos mais ligados ao crime organizado, no caso dos caminhoneiros (IBT), 
foi feita uma limpeza no quadro de dirigentes e membros e foi proposta, pela primeira vez na história deste sindicato, uma eleição genuína entre seus membros para a formação autêntica de seus representantes, pois as precedentes eram todas arrumadas de acordo com os grandes interesses particulares envolvidos. Apesar dos milhões de dólares gastos na implementação dos interventores nos sindicatos, pouco se sabe das mudanças reais efetivadas nestes em mais de 24 anos de atividades contra a criminalidade em sua atuação, principalmente, junto aos sindicatos de trabalhadores.

As dificuldades pelas quais a pesquisa não se desenvolve para o esclarecimento de muitas atividades, problemas e estratégias pertinentes à intervenção governamental naqueles sindicatos, parecem envoltas em mistérios e forças ocultas que dificultam sua elucidação, bem como os custos destas intervenções! Para o bom entendedor as palavras são necessárias, mas para o bom compreendedor uma palavra basta. A grande questão que se coloca é o quantum de ação do crime organizado que realmente foi expurgado dos sindicatos de trabalhadores e de que maneira foram eles mascarados por outras organizações criminosas ou mesmo por outras pessoas corrompidas. Pesquisas efetivadas segundo proposta da lei R.I.C.O. identificaram dificuldades na elucidação; chegam a ser constrangedoras, mas, por outro lado, são bastante esclarecedoras das forças políticas que continuam a agir na defesa de seus interesses particulares em detrimento dos da grande maioria dos trabalhadores que vêem agravar a sua situação, sem uma perspectiva de melhoria condizente, capaz de atenuar o desalento que impera no meio trabalhista.

O objetivo de expurgar a criminalidade dos sindicatos seria o de trazê-los de volta ao estado pleno de direito democrático, mas imperam as diferentes espécies de "grupos de interesses" agindo furtivamente em conformidade com suas determinações exclusivas, o que tem dificultado a representação do verdadeiro trabalhador honesto e cumpridor de suas obrigações cidadãs. A verdade é que o tempo não só disforma como desinforma a todos aqueles que não têm uma conduta consciente do seu porvir.

A prática da ocupação parece atrelada à política hegemônica e os resultados têm sido contrários ao bom senso, mas acordes com os instintos mais primitivos que ainda hoje comandam a humanidade a caminho da desarmonia e destruição.

A grande maioria dos membros dos sindicatos envolvidos com o crime organizado não parece estar muito preocupada com a sua participação efetiva na administração autêntica do sindicato, mas somente com a perspectiva de maximizar seus 
interesses particulares que, mancomunados a políticos, quando não a uma carreira política própria, acabam por influenciar negativamente as políticas públicas que supostamente deveriam estar voltadas para a melhoria das perspectivas dos trabalhadores.

A grande questão que se coloca seria: como desbravar os motivos reais do por quê este estudo tão esclarecedor, não só do trabalhismo norte-americano, mas também da sua própria "elite orgânica" 64 tem sido tão imprevidente?

Um paralelo conclusivo poderia ser tirado das dificuldades de poder contemplar dados reais que refutariam quaisquer tentativas de encobrir os grandes interesses hegemônicos em que políticos, sindicatos e crime organizado formam um complô na defesa de seus privilégios exclusivos em detrimento da grande maioria de trabalhadores e da própria sociedade norte-americana. Tal política reflete-se internacionalmente na defesa intransigente de seus interesses intervencionistas.

${ }^{64}$ DREIFUSS, René. A internacional capitalista: estratégias e táticas do empresário transnacional 19181986. $2^{a}$ edição. Rio de Janeiro: Espaço e Tempo, 1987, p. 21-51. 


\section{Capít u lo I V}

\section{EXPERIÊNCIA SINDICALISTA NO MÉXICO}

A industrialização mexicana não se consolidou dentro dos parâmetros da sua revolução cultural de 1910, mas da estrutura industrial do setor manufatureiro propiciado pelo vigoroso governo liberal de Porfírio Díaz (1830-1915) que entre 1877 a 1911, governou de maneira ditatorial com relativo progresso econômico advindo de um grupo de tecnocratas que orientaram sua política econômica. Nestes 34 anos de ditadura, governou de fato, com uma administração corrupta, mesmo que não tivesse ocupado a posição oficial de comando.

O despotismo de Díaz dera continuidade ao processo de exaustão dos recursos naturais e à exclusão do campesinato das terras cultiváveis em mãos de inversionistas estrangeiros que, aliados à oligarquia nacional, tinham total liberdade de empregá-los em condições espúrias, como forma de mantê-los à margem da sociedade, de maneira que lhes faltava o básico para sobrevivência e cidadania; reflexos ainda característicos e perceptíveis da exploração a que os nativos da Nova Espanha colonial foram submetidos pelas potências imperiais de então e cuja classe tem sido a base da sua força de trabalho. É interessante ressaltar que o governo do mixteque ${ }^{65}$ Porfirio Díaz (1876-1911) sobreveio como forma de contestação aos interesses capitalistas e que o governo sóbrio e intransigente de Benito Juarez (1858-1872) não observara quando confiscou as propriedades da igreja católica, limitou o poder militar e suspendeu o pagamento da dívida externa em 1861, veementemente protestado por França, Grã-Bretanha e Espanha.

No final do governo de Díaz, 85\% das terras estavam nas mãos de apenas 1\% da população e somente $3 \%$ da população rural possuía sua própria terra. O "porfiriato" foi executor inconteste na defesa dos interesses internacionais das grandes potências, graças as quais sua trajetória governamental longeva não foi perturbada, mas se deu em detrimento à formação de uma cultura econômica autônoma que pudesse ser economicamente mais sustentável e as relações de trabalho pudessem ser mais justas.

\footnotetext{
${ }^{65}$ Habitantes indígenas do sul do México, no Estado de Oaxaca, Chiapas etc.
} 
Com a dissolvência das propriedades comunais e sem uma perspectiva de melhoria para os excluídos, iniciou-se o processo de emigração para os Estados Unidos, com exceção daqueles que migraram para os grandes centros urbanos no México, principalmente "Ciudad Del México", dando uma continuidade mais dinâmica ao processo de industrialização secundária localizada, mas sempre de acordo com os reveses de uma economia inautêntica e gerando inquietação social nos centros urbanos por falta total de infra-estrutura condigna.

Antes do primeiro grande surto da industrialização secundária mexicana, propiciado pelo governo de Díaz, o grande aparato manufatureiro mexicano concentravase na indústria têxtil da cidade de Puebla, cuja posição geográfica tem sido estratégica na comunicação e distribuição de seus produtos, pois está localizada a meio termo entre Vera Cruz (porta de entrada do Atlântico) e Cidade do México no altoplano.

$\mathrm{Na}$ zona suburbana da cidade do México, surgiram pequenas indústrias têxteis, curtumes e moinhos movidos pela força hidráulica que era propiciada pelas águas dos rios que entrecortavam a região sudoeste. Deste cenário econômico despontava a formação dos primeiros círculos de trabalhadores daquelas áreas. Estas primeiras iniciativas próindustrialização proporcionaram o desenvolvimento da ferrovia movida a vapor e o respectivo pessoal de manutenção das vias, caldeiras e maquinários diversos e, a partir de 1876, foi fundada a Confederação de Associações de Trabalhadores dos Estados Unidos Mexicanos que, posteriormente, ramificou-se em diversas associações de trabalhadores ligados à incrementação da economia nacional em função das industrias têxteis, tipográficas e nas ferrovias para o transporte de suas imensas riquezas naturais.

$\mathrm{Na}$ cidade de Cananea foi fundada a União Liberal Humanidade, após a histórica greve de 5000 trabalhadores (1906) da maior mina de cobre e ouro, que estavam inconformados com os baixos salários e muitas horas de trabalho, em se comparando com os estrangeiros que recebiam 5 vezes mais e trabalhavam menos 4 horas do que os trabalhadores mexicanos. Com a solicitação de ajuda ao exército norte-americano feita pelo governador, foram enviados 500 soldados que, conjuntamente aos 100 soldados mexicanos, enfrentaram os grevistas com um saldo de 500 mortes de trabalhadores entre mulheres e crianças. Em 1912 foi fundada a Casa do Obreiro Mundial de tendências anarquistas que se propunha organizar os trabalhadores em sindicatos. 
Esta tem sido uma característica dos países latino-americanos ainda atrelados ao neocolonialismo e aos notórios aconchavos de uma minoria nacional subserviente que detém o prestígio e domínio e que, tornando-se uma vez abastada, acomoda-se em berço esplêndido. Com isso, perde-se toda uma perspectiva promissora de desenvolvimento econômico com maior sustentabilidade e o resultante bem-estar social para a grande maioria da população. Nos casos das ferrovias mexicanas (caso do Brasil também), no que diz respeito ao transporte dos produtos de exportação agrários e minerais, dos quais a industrialização secundária e acessória (ou tardia, como alguns preferem denominá-la) beneficiou-se de economias de escala, mas cuja decadência precoce tem sinalizado contra-sensos ímpares, mesmo considerando o baixo custo deste tipo de transporte que ocasionaria uma economia mais sustentável, caso continuassem a fazer uso mais intensivo dela, como têm ocorrido nos casos de países que tiveram o empreendimento inicial daquele investimento e que até hoje lhes trazem ótimas taxas de retorno e de manutenção de empregos. 


\subsection{O México pós-revolucionário}

O não desenvolvimento de uma segmentação oposicionista do setor privado e o projeto cultural de José Revueltas ${ }^{66}$ (1914-1976) e Octavio Paz foram características marcantes da revolução mexicana após 1910. Em 1916 formara-se um sindicato socialista de trabalhadores chamado Confederação do Trabalho da Região Mexicana (CTRM) que enfatizava a luta de classes com a apropriação dos meios de produção e com realce ostensivo na ação direta sindical sem o uso de meios políticos explícitos. Em $1^{\circ}$ de maio de 1918 fundara-se a Confederação Regional Obreira Mexicana (CROM) de ideal anarquista com a pretensão inicial de ser considerada uma unidade dentro de um movimento maior internacional, ainda que o movimento nacionalista fosse contrário a esta proposta de adesão. Durante os anos vinte do século passado, o CROM, apesar de várias vertentes ideológicas, conseguira influenciar os trabalhadores, mas, após a crise de 1928, o CROM finaliza sua trajetória inicial de ação direta, passando a estabelecer as bases de ação política que acabariam por atrelar os sindicatos ao Estado.

A Federação Americana do Trabalho (American Federation of Labor - AFL), fundada por Samuel Gompers, tivera conhecimentos da situação sindical do México por meio de trabalhadores emigrantes mexicanos em indústrias norte-americanas, fato que possibilitaria o engajamento de um estreito relacionamento desde a época do México porfirista (1870-1910, do presidente Porfírio Díaz). Uma comissão da American Federation of Labor (AFL) enviada ao México, em 1918, propusera a formação de uma Federação Pan-Americana de Sindicatos (Pan-American Federation of Labor - PAFL), com sucinta segunda intenção de intercessão em todo o hemisfério ocidental, mas que apesar do extensivo financiamento da AFL acabou por não se concretizar da maneira como fora idealizada.

A intenção de controle dos movimentos trabalhistas, com o pretexto de defender os interesses democráticos dos trabalhadores mexicanos, era mais evidente quando a AFL

\footnotetext{
${ }^{66}$ José Revueltas (1914-1976), nascido em Santiago Papasquiaro (Estado de Durango), autodidata, escritor prolífico, ativista e teórico político, socialista utópico, guia espiritual do movimento estudantil, cosmovisionário. Sua estada muito prolongada em prisões mexicanas alentou-o na formulação do realismo dialético o que atentava para que nos predispuséssemos a observar sempre a realidade em nossa volta, naquele momentâneo instante histórico, num esforço que nos pudesse igualmente mostrar, pouco a pouco, a universalidade do homem em seus diversos aspectos. Os anos de 1940 foram fundamentais nas transformações erigidas da sua literatura popular e pensamento.
} 
insinuava-se nos processos políticos locais, o que contradizia os próprios ideais aplicados à AFL dentro dos Estados Unidos, que era o compromisso principal de ordem econômica em benefício dos trabalhadores, sem se imiscuir na política partidária. A partir de então, a AFL começou a se conscientizar das dificuldades de separar os interesses políticos dos econômicos, principalmente no conturbado cenário internacional onde os interesses multinacionais são mais preponderantes.

Desde 1917, quando o presidente Venustiano Carranza (1859-1920) cogitara a nacionalização da produção de petróleo, o Departamento de Estado americano foi autorizado a efetuar, mais de perto, atividades investigativas sobre os líderes trabalhistas mexicanos mais conscientes da precária situação econômica do país e, para tal intento, foi utilizada a recém-criada PAFL, cuja presidência, na época era de Samuel Gompers. Foi nesta época que se formou todo o arcabouço graças ao qual as operações acobertadas tiveram início, especificamente junto aos movimentos trabalhistas ligados aos grandes interesses econômicos, ou seja, inversões em terras mexicanas e o delicado item petróleo para países extremamente dele dependente. O inter-relacionamento da AFL e do CROM tinha sido reprovado por vários segmentos do movimento sindical mexicano sob a alegação de excessiva influência norte-americana.

Após 1920, quando finalizava a sua revolução de caráter social-nacionalista, com aproximadamente 1.500.000 mortes no geral, tinha o México, de então, o governo débil de Álvaro Obregón que contribuía com certa morosidade nas almejadas reformas sociais. Ainda assim, remonta ao legado desta época a primeira Constituição (1917) do mundo pela qual se consagraram os direitos e garantias sociais tais como: o direito de associação, descanso no sétimo dia, salário mínimo, competência federal na resolução de conflitos do Contrato Coletivo de Trabalho (quando declarado obrigatório em mais de um estado), regulamentação do trabalho de menores e mulheres, jornada de 8 horas, segurança e saúde nos locais de trabalho, reconhecimento aos direitos dos trabalhadores e dos patrões (esses quanto à paralisação [paro = lock-out] e aqueles quanto à greve), cumulando um total de 30 itens de garantias trabalhistas. Contudo, o artigo 123, que tem regulado sobre matéria trabalhista, é contraditório, pois decorre de uma análise insatisfatória, quando consagra em nível constitucional, elemento de difícil realização: a criação de empregos, desde que sua efetivação dependa da relação eficaz dos fatores de produção na economia e não somente da intenção correta do legislador. 
Artículo 123 - Toda persona tiene derecho al trabajo digno y socialmente útil; al efecto, se promoverán la creación de empleos y la organización social para el trabajo, conforme a la Ley.

Implicitamente, conforme disposto na constituição de 1917, o preceito da luta de classes é outorgado entre os detentores da força de trabalho e do capital. O princípio da autonomia da vontade individual é rompido em contraposição ao sujeito coletivo do contrato de trabalho, conforme determinação da lei civil que, assim, garante a sua oficialização.

As diversas reuniões dos trabalhadores, face à falta de unidade no movimento laboral e de uma ideologia específica da classe trabalhadora, tiveram como resultado a formação de muitas agremiações, dentre as quais, a Confederação Geral de Trabalhadores e Campesinos do México que, mesmo considerando o pouco tempo de atuação, conseguira arregimentar um grande numero de adeptos, apesar da situação dispersante que tem caracterizado não só os trabalhadores mexicanos, mas os trabalhadores latinoamericanos em geral.

Entre 1934-1940, iniciara-se com o presidente da república, general Lazaro Cárdenas, um processo que objetivara a organização da sociedade por meio de sindicatos, confederações e ligas nas quais se oferecesse aos trabalhadores uma maior efetivação do Contrato Coletivo de Trabalho, bem como uma representação no Congresso Nacional. O plano sexenal que resultaria no milagre Mexicano, fruto da constituição de 1917, entre outros direitos dedicava-se à educação, ao regime campesino com a submissão da propriedade privada ao interesse social, proibição de monopólios e proteção dos consumidores.

$\mathrm{Na}$ fase correspondente ao primeiro ano de seu governo, tendo sido muito criticado pela elite por causa de seu ideal socializante, mas sem o devido respaldo econômico, Cárdenas foi incapaz de controlar os trabalhadores descontentes com o ideal frustrado. O movimento dos trabalhadores estava bastante dividido, mas tinha certa independência do Estado e fora conseqüência das pressões dos grandes interesses capitalistas quanto à interferência que sua política social causaria aos interesses do comércio e indústria. Tais pressões foram bem arquitetadas e cumpridas à risca pelos oficiais das embaixadas dos países envolvidos. Parte da elite, ainda comprometida com os ideais porfiristas, foi facilmente manobrada para a delineação das novas perspectivas 
condicionantes que o processo histórico tão bem nos ilustra. Em 1929, através de uma emenda constitucional (art. 73), foi proibido aos Estados legislarem matéria trabalhista, cabendo ao governo federal o ordenamento legal de todas as leis do trabalho.

A lei federal do trabalho de 1931 (Ley Federal Del Trabajo - LFT), resultado da regulamentação do artigo 123 da Constituição de 1917, subdividida em sete tópicos sobre relações coletivas de trabalho (Relaciones Colectivas de Trabajo), contempla a estruturação do Contrato Coletivo de Trabalho e o Contrato-Lei, conforme discriminados nos capítulos 3 e $4 .^{67}$

O artigo 360 da LFT classifica os sindicatos em classes:

1. Mesma profissão, ofício ou especialização que são denominados "gremiales". Ex: alfaiates, encanadores etc.

2. Trabalhadores de uma mesma empresa. Ex: Volkswagen de Puebla etc.

3. Sindicatos industriais: trabalhadores de duas ou mais empresas do mesmo ramo industrial.

4. Nacional de indústria: trabalhadores de uma ou várias empresas do mesmo ramo industrial, em dois ou mais Estados.

5. Multiofícios: trabalhadores de diversas profissões. Só podem se formar na cidade onde o número de trabalhadores da mesma profissão seja inferior a 20 elementos.

O artigo 361 regulamenta as câmaras patronais (sindicatos patronales) em duas categorias:

1. Local: câmara patronal formada de um ou vários ramos de atividades (mínimo de três).

2. Nacional: formada de um ou vários ramos de atividades (mínimo de três), em vários Estados.

O registro do sindicato é feito de acordo com sua competência: se federal (art. 527, têxtil, elétrica, açúcar etc.), na Secretaria de Trabalho e Previsão Social; se local, nas Juntas de Conciliação e Arbitragem.

Característica interessante no que tange às normas jurídicas trabalhistas mexicanas é a figura do Contrato-Lei e do Contrato Coletivo de Trabalho. Os artigos 386

\footnotetext{
${ }^{67}$ Verificar os capítulos 3 e 4 completos e traduzidos no apêndice, p. 228.
} 
a 403, que apresentam nítida influência do modelo norte-americano, regulamentam os Contratos Coletivos de Trabalho.

O Contrato Coletivo de Trabalho de cunho compulsório foi designado pela Lei Federal do Trabalho de "Contrato-Lei", mas este não pode ser considerado uma lei nem mesmo um contrato, propriamente dito, pois um não se origina do Poder Legislativo e outro não demanda anuência de vontades, uma vez que tanto do lado patronal como dos trabalhadores, a outorga poderia dar-se pelo capricho da maioria. Com um enfoque ainda bastante corporativista de tutelas jurídicas promovidas pelo Estado, o Contrato-Lei pretende englobar seu raio de ação para além das indústrias que a tenham convalidado e atingir toda uma categoria profissional de maneira compulsória. Estaria mais bem definido como um desfecho satisfatório emanado de uma câmara de conciliação onde governo, empresas e trabalhadores tentam um ponto de equilíbrio fundamentado nas experiências históricas destas relações de uma categoria profissional.

No caso de o Contrato-Lei envolver dois ou mais Estados, a solicitação deverá ser feita à secretaria do Trabalho e Previdência Social ou ao governador do Estado, quando for o caso de empresas de jurisdição local e com representação de, pelo menos, $2 / 3$ dos trabalhadores sindicalizados.

Em suma, as diferenças fundamentais entre o Contrato-Lei e o Contrato Coletivo no ordenamento jurídico mexicano do trabalho são:

I. O Contrato-Lei é, na realidade, um pseudocontrato bastante abrangente de uso em setores industriais ou zonas econômicas, mormente nas indústrias manufatureiras mais tradicionais, podendo ter abrangência nacional; o Contrato Coletivo de Trabalho é um contrato de empresas com regras assentes, mais determinadas e, contemporaneamente, com forte tendência ao ajuste neoliberal.

II. O Contrato-Lei deve ser registrado na STPS (mais abrangente), o Contrato Coletivo no JCYA (mais localizado).

III. O Contrato-Lei poderia ser assinado por várias entidades sindicais e patronais (2 ou 3), enquanto que o Contrato Coletivo poderia ser assinado por uma só.

IV. O Contrato-Lei deve ser revisto e poderia ser reformulado a cada 3 meses antes do prazo de encerramento, o Contrato Coletivo de Trabalho em dois meses.

V. O Contrato-Lei não poderá superar dois anos de prazo, conquanto o Contrato Coletivo de Trabalho não apresenta limites precisos, ainda que mormente se renove 
a cada dois ou três anos desde que denunciado, o que nem sempre acontece na maioria dos casos mexicanos, como já delineado no presente trabalho.

VI. O Contrato-Lei é, na realidade, um Contrato Coletivo Obrigatório, instituto este que, no Brasil, denomina-se convenção coletiva de trabalho, inserida na CLT e bastante abrangente até 28 de fevereiro de 1967 quando a lei federal número 229 ab-rogou vários de seus artigos.

O corporativismo, tão velho e tão novo não só no Brasil, tem tido propósitos vários, dentre os quais aquele que pretende ser uma ferramenta de representação política em que se pactua com os segmentos econômicos e sociais com o propósito explícito de eliminar os conflitos de classes entre os diversos atores e que, bem subordinados ao Estado, garantem a ele o autoritarismo que tem sido muito bem caracterizado nas relações do Estado com os sindicatos. Após as reformas do Partido da Revolução Mexicana (PRM) surgia, em 1946, com esta denominação, o Partido Revolucionário Institucional $(\mathrm{PRI}){ }^{68}$ de caráter mais corporativista, que previa maior influência do Estado na economia. O PRI centralizou-se ainda mais e deu poder quase absoluto ao presidente da república que, assim, esforçou-se para harmonizar, controlar e organizar a política e, ainda, torná-la eficaz no trato com os diversos segmentos da sociedade, caracterizando bem o regime "priista". O que caracterizou fundamentalmente o PRI foi a mudança de ideologia, que agora se tornara nacionalista revolucionária, deixando para trás as lutas de classes em voga até então.

${ }^{68}$ O PRI foi fruto do Partido Nacional Revolucionário (PNR) fundado em 1929 por Plutarco Elias Calles, que reunira os diversos grupos revolucionários, mas foi denominado de Partido da Revolução Mexicana (PRM) por Cárdenas em 1938. 


\subsection{Classificação dos sindicatos no México}

De acordo com a Constituição mexicana e a Lei Federal do Trabalho, existem somente duas classes de sindicatos:

1. Sindicatos de Trabalhadores;

2. Sindicatos Patronais.

A classificação dos sindicatos de trabalhadores, conforme Art. 360 da Ley Federal Del Trabajo (LFT), divide-se em cinco categorias:

1. Sindicatos Gremiais (Gremiales) - formados por trabalhadores de uma mesma profissão, ofício ou especialidade. Dada a exigüidade que caracteriza sindicatos de ofício no contexto contemporâneo de multifuncionalidade e interregionalidade produtiva, torna-se precária sua função tradicional de luta, para se situarem no front das acirradas disputas do competitivo mundo globalizado.

2. Sindicato de empresa - formado por trabalhadores que prestam seus serviços em uma mesma empresa independentemente de suas especialidades. As soluções dos problemas trabalhistas são mais diretas e imediatas, pois, neste caso, esta categoria sindical encontra-se inserida na realidade político-econômica de um dado local e momento específicos. A competência do sindicato está delimitada à empresa da qual os sindicalistas fazem parte e cabe ao Superior Tribunal de Justiça decidir, caso não esteja registrado na Federación de Sindicatos de Empresas de Bienes y Servicios (FESEBS) e em nenhum outro sindicato nacional de indústria em que os trabalhadores que prestam aquele serviço, pleiteiem organizar-se. Dada a precariedade dos sindicatos de proteção, torna-se a alternativa mais condizente com as peculiaridades econômicas do momento, principalmente, para os trabalhadores das "zonas maquiladoras". Os sindicatos deste tipo caracterizam-se pela dispersão, pois não favorecem uma estratégia comum aos trabalhadores de uma determinada cadeia produtiva.

3. Sindicato Industrial (Industriales) - formado por trabalhadores que prestam seus serviços em duas ou mais empresas do mesmo ramo industrial num mesmo Estado. O ramo industrial aqui está subentendido como uma atividade comum dos trabalhadores incorporados por uma determinada indústria. 
4. Sindicato Nacional da Indústria (Nacionales de la Industria) - formado por trabalhadores que prestam seus serviços em uma ou várias empresas do mesmo ramo industrial, instalada(s) em dois ou mais estados.

5. Sindicato de vários ofícios formado por trabalhadores de diversas profissões. Este somente será constituído quando o número de trabalhadores de mesma profissão for menor do que vinte em um determinado município, de maneira que, destarte, poderá negociar o contrato coletivo ou uma greve com uma ou várias empresas.

Também podem formar parte dos sindicatos de trabalhadores os maiores de quatorze anos, mas, pelo menos, vinte trabalhadores ativos deverão ser considerados para a sua formação. Não podem ingressar os trabalhadores de confiança, pois os estatutos dos sindicatos podem determinar a condição e os direitos de seus membros, para que sejam promovidos a um posto de confiança.

Os sindicatos patronais podem ser classificados, conforme Art. 361 da Ley Federal del Trabajo (LFT), em duas categorias:

1. Sindicatos locais (Locales) - formados por patrões de um ou vários ramos de atividades-locais; estes congregam os Centros Patronais (Centros Patronales).

2. Sindicatos nacionais (Nacionales) - formados por patrões de um ou vários ramos de atividades de diversos estados; estes são congregados pela Confederação Patronal da República Mexicana (COPARMEX).

Estes sindicatos devem constituir-se de, pelo menos, três patrões. 


\section{Ca pít u lo V}

\section{EXPERIÊNCIA SINDICALISTA NO BRASIL}

\subsection{Experiência sindical no Brasil pré-1964}

Da maneira pela qual nasceu o sindicato na Inglaterra, quando o processo industrial transformara a água sob pressão em partículas gasosas por efeito da ebulição, resultando em energia motora, foi neste ambiente que se deu a introdução da incipiente organização da força de trabalho, concomitantemente ao agrupamento da classe empresarial proprietária dos meios de produção que contava com as matérias primas essenciais ao processo produtivo: carvão e ferro.

O Brasil já assegurava o direito de associação e liberdade de trabalho na Constituição Imperial de 1824, outorgada por Dom Pedro I, o que na Inglaterra acontecera em 1825, entretanto a nossa industrialização era espúria e continuávamos sendo os maiores importadores de escravos da história com grandes latifúndios que não se coadunavam com a difusão deste modelo advindo da Europa em plena revolução industrial de meados do século XIX.

O processo produtivo na nossa Industrialização secundária, segundo preceito da CEPAL, ${ }^{69}$ denominado de "substituição de importações", tinha uma estrutura concentradora com a adoção de tecnologias importadas de uso mais intensivo de capital. Absorveria e remuneraria o capital muito mais do que a mão-de-obra, cuja veemência desta última é muito superior ao capital em si, aspecto controvertido que vem, desde há muito tempo, imperando nas relações de trabalho. O capital adaptando-se à técnica mecânica vislumbra um horizonte linear não contíguo por não se fazer premente à primordialidade da vida.

O estopim da crise de 1964, que se anunciava, foi o manifesto dos trabalhadores, proclamado pelo Comando Geral dos Trabalhadores (CGT) através da Comissão Permanente de Entidades Sindicais, Profissionais, Camponesas e Estudantis em 17 de

\footnotetext{
${ }^{69}$ Comissão Econômica para a América Latina. Órgão regional da ONU, fundado em 1948, conta com a participação de todos países latino-americanos e Estados Unidos, Grã-Bretanha, França e Holanda.
} 
agosto de 1962, na recém-criada cidade de Brasília. O CGT nasceu durante o IV Congresso Sindical Nacional dos Trabalhadores neste mesmo ano, em São Paulo, quando o Comando Geral de Greve (CGG) foi transformado em CGT com o apoio das principais entidades sindicais. Com uma greve geral iminente, o comando defendia as liberdades democráticas e sindicais e as reformas de base com a participação dos trabalhadores.

O princípio orientador forasteiro tem profetizado que qualquer que fosse a causa da debilitação econômica faria, no primeiro momento, crescer a dependência administrativa a favor dos sindicatos e a subseqüente iminência ideológica comunista pronta a se instalar no meio trabalhista. Uma conjunção de elementos dependentes daquela situação econômica forçaria o governo a tomar medidas contra o perigo vermelho que ameaçava as hegemonias, a fim de resgatar sua situação política. A fundação da União Sindical dos Trabalhadores (UST), no começo de 1964, foi a contrapartida ao Comando Geral dos Trabalhadores. 


\subsubsection{Classificação dos sindicatos no Brasil}

No Brasil, têm merecido destacadas reflexões o registro, a unicidade, o imposto sindical e a maneira pela qual se organizam os sindicatos:

1. a "Carta Constitucional" de 1937, no artigo 138, destacava a necessidade do registro legal pelo Estado da entidade representativa, por seu turno, a Constituição de 1988, no artigo $8^{\circ}$, inciso I, reinterpretou a liberdade e a autonomia sindical, mas também destacou a necessidade do reconhecimento sindical junto à instituição competente; entretanto, em ambas Constituições, não se determina taxativamente qual a instituição em que tal reconhecimento deveria ser feito. Estes pequenos detalhes demonstram a falta de coerência necessária para a efetivação da proposta.

2. o Brasil é tido como sui generis quanto a sua maneira de organizar-se, pois existe uma unicidade sindical legal (Sindicatos dos Arrumadores de Airoses, no Piauí; Metalúrgicos do $\mathrm{ABC}$ etc.) em contraste com sua pluralidade de fato, verificada através das centrais de trabalhadores: Central Única dos Trabalhadores (CUT), Central Geral dos Trabalhadores (CGT), Central Geral dos Trabalhadores Brasileiros (CGTB), Força Sindical (FS) etc.

O princípio da unicidade sindical determina que os trabalhadores devem ser automaticamente sindicalizados em organismos sindicais específicos, e isto decorre do conceito corporativista caracterizado pela demasiada intervenção do Estado. Poder-se-ia teorizar que, no Brasil, existe a execução intransigente deste princípio na base sindical, o que não ocorre na cúpula.

Com o êxito do Estado Novo, que reverteu a tendência à formação de sindicatos pluralistas, conforme a Constituição de 1934, art. 120, parágrafo único: “A lei assegurará a pluralidade sindical e a completa autonomia dos sindicatos", mas na Carta Constitucional de 1937, numa acintosa influência dos jurisconsultos e historiadores, o legislador redefiniu a formação sindical única por categoria. Denota-se nesse vai-e-vem as influências de forças coercitivas neocolonialistas na configuração adequada aos seus interesses, sugerindo a parcialidade, pois, às vezes, a ação política nacional possui um pendor em prol daqueles interesses que produzem, com o passar do tempo, situações 
deploráveis, tanto no plano econômico, mas como também no social, o que se comprova com a desigualdade causada pela má distribuição de renda, fator esse que descaracteriza o fortalecimento de uma nação.

No que se refere à proteção trabalhista, a Carta Constitucional de 1937 apresentou algumas alterações e acréscimos, mas foi amplamente recepcionada da Constituição de 1934, que poderíamos definir como concernente ao direito do trabalho, ainda que o dispositivo quanto à autonomia sindical, constante no artigo 120 da Constituição de 1934, nunca tivesse sido regulamentado, ato que lhe tirava a eficácia pela qual havia sido preceituada. $\mathrm{O}$ direito individual do trabalho concedia proteção plausível ao trabalhador, mas, em contrapartida, os sindicatos sem liberdade, autonomia e direito à greve, relegavam o direito coletivo do trabalho ao desalinho com o autêntico poder sindical. O termo "Convenção Coletiva", presente na Constituição de 1934, foi mudado para "Contrato Coletivo", três anos depois, na Constituição de 1937.

A seguir reproduzimos os artigos 61, 62, 138 e 139 da Carta Constitucional de 1937:

\section{CARTA CONSTITUCIONAL DE 1937}

Artigo 61 - São atribuições do Conselho da Economia Nacional:

a) promover a organização corporativa da economia nacional;

b) estabelecer normas relativas à assistência prestada pelas associações, sindicatos ou institutos;

c) editar normas reguladoras dos contratos coletivos de trabalho entre os sindicatos da mesma categoria da produção ou entre associações representativas de duas ou mais categorias;

d) emitir parecer sobre todos os projetos, de iniciativa do Governo ou de qualquer das Câmaras, que interessem diretamente à produção nacional;

e) organizar, por iniciativa própria ou proposta do Governo, inquérito sobre as condições do trabalho, da agricultura, da indústria, do comércio, dos transportes e do crédito, com o fim de incrementar, coordenar e aperfeiçoar a produção nacional;

f) preparar as bases para a fundação de institutos de pesquisas que, atendendo à diversidade das condições econômicas, geográficas e sociais do País, tenham por objeto: 
I - racionalizar a organização e administração da agricultura e da indústria;

II - estudar os problemas do crédito, da distribuição e da venda, e os relativos à organização do trabalho;

g) emitir parecer sobre todas as questões relativas à organização e reconhecimento de sindicatos ou associações profissionais;

h) propor ao Governo a criação de corporação de categoria;

Artigo 62 - As normas, a que se referem às letras b e c do artigo antecedente, só se tornarão obrigatórias mediante aprovação do Presidente da República.

Artigo 138 - A associação profissional ou sindical é livre. Somente, porém, o sindicato regularmente reconhecido pelo Estado tem o direito de representação legal dos que participarem da categoria de produção para que foi constituído, e de defenderlhes os direitos perante o Estado e as outras associações profissionais, estipular contratos coletivos de trabalho obrigatórios para todos os seus associados, imporlhes contribuições e exercer em relação a eles funções delegadas de Poder Público.

Artigo 139 - Para dirimir os conflitos oriundos das relações entre empregadores e empregados, reguladas na legislação social, é instituída a Justiça do Trabalho, que será regulada em lei e à qual não se aplicam as disposições desta Constituição relativas à competência, ao recrutamento e às prerrogativas da Justiça comum.

A greve e o lockout são declarados recursos anti-sociais nocivos ao trabalho e ao capital e incompatíveis com os superiores interesses da produção nacional.

A confusão conceitual (convênio, contrato, convenção e acordo coletivo de trabalho) caracteriza bem esta época de forte persuasão e que até hoje não foi restaurada da maneira como conviria para um melhor entendimento da matéria.

A convenção coletiva apareceu, primeiramente, em 1932 através do decreto 21761 representando semelhança ao estatuto francês de 25 de março de 1919, que regulamentava o regime de convenções coletivas, dando aos assalariados uma lei efetiva que contribuiu para eliminar sérios antagonismos, tendo sido o resultado de longos debates desde a vigência de uma lei de 1884 que versara sobre a liberdade de associação sindical.

O espírito da lei francesa de 1919 dizia respeito às disputas de propriedade quanto às denominações de regiões específicas produtoras de vinhos de boa qualidade; 
após a convenção coletiva, o direito foi adequado aos produtores que, então, estabeleciam no rótulo sua marca com as características da região produtora: Champagne, Borgonha, D’Or etc. Em França, o conceito de convenção coletiva tem a mesma conotação que no Brasil: um acordo relativo às condições de trabalho, concluída entre, de um lado, um ou vários sindicatos de empregados e, de outro lado, uma ou várias organizações de empregadores.

A Constituição de 1934, artigo 121, §1º, alínea “j”, reconhece as "convenções coletivas" do trabalho, contudo, no texto da Constituição de 1937, era atribuição do Conselho da Economia Nacional: "editar normas reguladoras dos contratos coletivos do trabalho entre os sindicatos da mesma categoria da produção ou entre associações representativas de duas ou mais categorias".

A partir do Decreto-lei 5452/43 (Consolidação das Leis Trabalhistas - CLT), o nome Contrato Coletivo de Trabalho foi mantido e denominava o caráter normativo em que 2 ou mais sindicatos representantes das categorias econômicas e profissionais estabeleciam condições para reger as relações individuais de trabalho, no âmbito de suas representações. A partir do Decreto-lei 229/67 foi excluída a frase "Contrato Coletivo do Trabalho", sendo substituída por "Convenção" ou "Acordo Coletivo do Trabalho" em todos os artigos do título VI da CLT, embora vários artigos desta ainda não tenham sido atualizados, a exemplo do que ocorreu nos artigos 59, 61, 71, 235, 239, 295, 391, 444, 462 e 513. Denotam-se, por meio desta escolha lingüística, as singularidades no emprego de termos mais adequados aos interesses em jogo, da coerência do uso conforme as especificidades históricas e culturais, pois "Convenção Coletiva" não indica tanto o caráter de relevância normativa e compulsória conferida à natureza do "Contrato Coletivo" em si, de feição mais civilista.

O Contrato Coletivo de Trabalho foi instituído de maneira mais categórica na Europa e nos Estados Unidos após a Segunda Guerra Mundial, época que se caracterizou por um forte crescimento econômico.

Desde a nossa época colonial, a característica elitista fora sempre ser muito receptiva e esplendorosa dos magníficos acontecimentos alhures, numa mistura de abstração e indeterminação, com o acolhimento, de tempo em tempo, destas influências, mas com um questionamento inadequado à nossa realidade. Discutia-se qual a teoria que melhor se adaptaria e acabava por se omitir à formulação de uma teoria mais genuína, em 
conformidade com os fatos, cujo detalhamento refletisse a realidade específica de um povo, dando suporte e sustentabilidade ao sistema de desenvolvimento econômico, tornando lícito o crescimento real do bem-estar social com o fortalecimento das relações coletivas de trabalho.

O Decreto-lei nº 1402 de 1939, que regulamentou a formação do sindicato e que foi, na maior parte, recepcionado pela Consolidação das Leis do Trabalho (CLT) em seu título V, através do Decreto-lei $\mathrm{n}^{\mathrm{o}} 5.452$, de $1^{\circ}$ de maio de 1943 , foi o contexto que resultou na transcrição do trecho original da "Carta di Lavoro" (1927) em seu artigo III, da então Itália fascista de Benito Mussolini, onde as corporações profissionais, diretamente instituídas e controladas pelo governo, substituíram os sindicatos mais aguerridos de trabalhadores inclinados ao anarcossindicalismo. Uma análise mais acurada do ambiente econômico entre-guerras mundiais, (fim do liberalismo econômico, conseqüências da queda da Bolsa de Nova Iorque de 1929, keynesianismo) e político (Getúlio Vargas e o Estado Novo, New Deal de Roosevelt e o fascismo de Benito Mussolini), evidencia o aumento de influências que caracterizaram muito bem esta época mutacional mais grave, num misto de influências impregnadas de valores integralistas nacionalistas, do autoritarismo fascista, estatutos franceses e a forte influência da política externa norte-americana.

A Assembléia Constituinte de 1988 foi paradoxal, pois não obstante tenha consagrado autonomia e liberdade sindicais, conservou a segmentação na organização sindical por categoria e o registro obrigatório, tornando-se manifesto o conservadorismo corporativista que atrela os sindicatos de trabalhadores ao Estado. As confrontações de pessoas pró-unicidade e em prol da pluralidade com suas respectivas razões têm refletido nas resoluções político-trabalhistas, de maneira a não favorecer o equilíbrio necessário em tal relação, historicamente instável, principalmente num mundo em rápida transformação que caracteriza a globalização sob a égide neoliberal.

A falta de um modelo autônomo de acordo com características culturais, políticas, econômicas e religiosas próprias em nada favorece as tentativas de correlações necessárias quando se procura o equilíbrio sustentável nestas relações. Os diferentes interesses privados aliados em escala globalizada não se coadunam com o interesse coletivo dos seres humanos em escala planetária. Carecemos de uma ferramenta que seja 
capaz de viabilizar projeto de tal envergadura a fim de garantir sustentação à fragilidade da vida comum a todos.

Às vezes faz-se necessária para a conservação da própria vida uma mudança gradual e equilibrada para que não haja um colapso do sistema, de modo que nos adaptemos à mudança que as forças imperiais impõem ao mundo de maneira bastante controversa. Nas palavras do prezado jurista abaixo, seria conveniente uma pequena modificação: no lugar de "removê-los" colocarar-se-ia: "convencê-los a se mudar de fato". Somente quando conseguimos nos mudar internamente é que teríamos condição de mudar alguma coisa, quanto ao mais é pura fantasia que resulta não ser sustentável.

A sindicalização por categoria é coisa do passado, inteiramente desatualizada, completamente desajustada ao mundo presente. Só se sustenta no Brasil, graças à mentalidade dominante, que autoriza a permanência de privilégios assegurados aos exercentes do poder sindical - patronal e de trabalhadores - que em nada cedem, apegados, como ostras ao rochedo, às posições de mando das quais ninguém consegue removê-los. ${ }^{70}$

\footnotetext{
${ }^{70}$ ROMITA, Arion Sayão. Sindicalização por categoria. In: Revista LTr, São Paulo, vol. 59, n. 3, mar.1995,
} p. 307. 
5.1.2. Descrição dos alicerces do sistema nacional de relações do trabalho

A. Sistema de unicidade sindical de representação da categoria profissional

Neste sistema só pode haver um sindicato para cada categoria econômica dentro de um setor territorial definido. Denominamos de "unicidade do sistema" da qual alguns sindicatos mais progressistas opõem-se e promoveram a formação de "centrais sindicais" que são organismos políticos totalmente independentes da tutela do Estado, ainda que esforços tenham sido envidados para sua regulamentação.

\section{B. Base territorial da representação}

A base territorial mínima é idêntica à base do próprio município. $\mathrm{O}$ sindicato não pode ter base territorial menor do que um município, mas pode ter base em outros municípios, num estado ou ter base nacional, como é o caso do Sindicato Nacional dos Aeronautas. A representação exercida pelas entidades sindicais é obrigatória, pois o trabalhador da categoria precisa da entidade sindical, uma vez que é afetado pelas suas decisões, independentemente de sua filiação àquele sindicato.

\section{Representação obrigatória e automática}

O sindicato de determinada categoria representa os trabalhadores, mesmo aqueles que não são filiados, sem que haja uma "cessão de poder" para o exercício desta representação e concede compulsoriamente o custeio daquela representação ao trabalhador: o imposto sindical é obrigatório e não depende de filiação ao sindicato.

O sistema unitário prevê um escalonamento hierárquico sindical, em que a representação dos trabalhadores é organizada mediante instâncias de diversas categorias:

- $\quad$ Primeira categoria: Sindicatos.

- Segunda categoria: Federações.

- Terceira categoria: Confederações (máximo da organização vertical). 
D. Organização setorial, com base em uma profissão, e não uma base de ramo industrial

No texto constitucional de 1988, com a unicidade sindical preservada, não sobrou lugar para as Centrais Sindicais, pois estas só têm significado num sistema de pluralismo sindical. As "centrais sindicais" são entidades mais de apoio políticoeconômico do que de ajuda legal-jurídica, as reivindicações políticas são mais intensas e mais se adaptam à agilidade necessária desta incessante, dinâmica e veloz transformação do sistema capitalista. A mutação por que passa a sociedade faz com que o conservadorismo do sistema legal-jurídico não tenha sido capaz de acompanhar as rápidas mudanças, de modo a poder oferecer ajuda mais condizente com a situação contemporânea. Se observarmos a realidade que nos envolve desde há muito tempo, verifica-se que nosso sistema apresenta falhas em quase todos os aspectos.

O sistema de unicidade sindical em vez de multiplicar as condições autênticas da representação trabalhista, desmembra a estrutura sindical com restrições setoriais, e esta é a desvantagem deste sistema de organização, pois se desvanece a expectativa de união dos diversos grupos de trabalhadores, o que, aliás, parece ter sido a intenção dos legisladores quando a produziram, mais de acordo aos interesses econômico-financeiros pró-capital envolvidos na época.

Não existe na estrutura legal-jurídica do sistema de unicidade sindical nenhuma instituição de trabalhadores que reúna grande parte dos sindicatos, nos moldes de como acontece informalmente com uma "central de trabalhadores", mas a formulação de várias Centrais também descaracteriza a unidade dos trabalhadores no sentido de enfraquecimento para a luta desigual que sempre se retratou na relação com o capital. A tarefa cabe ao Estado paternalista, que exerce o controle do movimento sindical. Esta é uma idéia que remete ao fascismo, quando não se permitiam quaisquer tipos de organizações sociais sem que o Estado as controlasse. 
5.1.3. A peculiaridade do sindicalismo brasileiro

A idéia de pluralismo implica reconhecer situações e idéias interdependentes; admitir que, em sendo coesas, idéias tendem a se harmonizar; sendo que as negociações entre grupos dependem de esforço conjunto na divisão de responsabilidades com capacidade suficiente para atingir metas, identificando o potencial das diferentes esferas do poder nas decisões políticas.

Nenhum conjunto de pessoas tem o privilégio legal ou de fato da posse exclusiva do poder e, à maneira clássica, o Estado funciona como um juiz imparcial que implementa políticas e cria normas de influência mútua de órgãos inter-relacionados, de acordo com o equilíbrio necessário para que a influência histórica do capital não se sobreponha taxativamente aos direitos mínimos dos trabalhadores.

Os problemas têm sido os oligopólios, poderio ursupador de muitos com características monopolizantes dominadoras, que hoje se denominam, mais apropriadamente, de redes corporativas transnacionalizadas que se sofisticaram e aperfeiçoaram a sua lógica de acumulação a ponto de deixarem o poder estatal e sindical quase sem efeito na intervenção em prol do bem-estar social do trabalhador.

Os organismos internacionais como hoje se apresentam, são mais entidades que defendem os pontos de vista dos grandes países capitalistas, capitaneadas pelas suas corporações transnacionais, cuja racionalização e eficiência econômica têm em vista apenas os seus próprios interesses que, muitas vezes sobrepõem-se às necessidades humanas vitais. Estas partem do princípio de que a divisão dos movimentos políticos e trabalhistas enfraquece as bases e, portanto, torna-se mais fácil manipulá-las. Após a segunda guerra mundial, com o advento da guerra fria, a luta ideológica contra o comunismo fora condição necessária para a vitória da democracia, e foi neste clima que a convenção 87 da OIT acabou sendo incrementada com o objetivo iminente de conter o avanço comunista junto aos movimentos de trabalhadores do que de servi-los, pois os detentores do poder capitalista não podiam conceber a perda pela revolução proletária dos trabalhadores.

A experiência de adoção do sistema de organização sindical no Brasil ocorreu, primeiramente, a partir da Constituição Federal de 1934 (Art.120) outorgada pelo governo 
Vargas, de ideais democráticos e liberais nela incrustados, tendo sido moldada a partir do modelo do regime inglês parlamentarista com características de imposição diversas àquele modelo clássico:

Artigo 120 - Os sindicatos e as associações profissionais serão reconhecidos de conformidade com a lei.

Artigo 121 - A lei promoverá o amparo da produção e estabelecerá as condições do trabalho, na cidade e nos campos, tendo em vista a proteção social do trabalhador e os interesses econômicos do País.

j) reconhecimento das convenções coletivas de trabalho.

$\S 2^{\circ}$ - Para o efeito deste artigo, não há distinção entre o trabalho manual e o trabalho intelectual ou técnico, nem entre os profissionais respectivos.

$\S 3^{\circ}$ - Os serviços de amparo à maternidade e à infância, os referentes ao lar e ao trabalho feminino, assim como a fiscalização e a orientação respectivas, serão incumbidas de preferência a mulheres habilitadas.

$\S 4^{\circ}$ - $\boldsymbol{O}$ trabalho agrícola será objeto de regulamentação especial, em que se atenderá, quanto possível, ao disposto neste artigo. Procurar-se-á fixar o homem no campo, cuidar da sua educação rural, e assegurar ao trabalhador nacional a preferência na colonização e aproveitamento das terras públicas.

$\S 5^{\circ}$ - A União promoverá, em cooperação com os Estados, a organização de colônias agrícolas, para onde serão encaminhados os habitantes de zonas empobrecidas, que o desejarem, e os sem trabalho.

$\S 8^{\circ}$ - Nos acidentes do trabalho em obras públicas da União, dos Estados e dos Municípios, a indenização será feita pela folha de pagamento, dentro de quinze dias depois da sentença, da qual não se admitirá recurso ex-officio.

Artigo 122 - Para dirimir questões entre empregadores e empregados, regidas pela legislação social, fica instituída a Justiça do Trabalho, à qual não se aplica o disposto no Capítulo IV do Título I.

Parágrafo único - A constituição dos Tribunais do Trabalho e das Comissões de Conciliação obedecerá sempre ao princípio da eleição de membros, metade pelas associações representativas dos empregados, e metade pelas dos empregadores, sendo o presidente de livre nomeação do Governo, escolhido entre pessoas de experiência e notória capacidade moral e intelectual.

Artigo 123 - São equiparados aos trabalhadores, para todos os efeitos das garantias e dos benefícios da legislação social, os que exerçam profissões liberais. 
As conseqüências foram tão calamitosas que o sistema foi alterado 3 anos depois, na Constituição de 1937. A criação de inúmeros sindicatos fantasmas, efetuada por candidatos interessados em se eleger representantes na Câmara Federal, acontecia porque a mesma Constituição Federal de 1934, em seu Art. 23, previa que, para se ser candidato a deputado federal seria preciso que houvesse a indicação de nomes por meio de uma organização profissional legalizada, neste caso, um sindicato de trabalhadores.

De acordo com esta conjuntura, os candidatos a deputado federal criavam sindicatos de trabalhadores onde exerciam aquela indicação, a saber:

Artigo 23 - A Câmara dos Deputados compõe-se de representantes do povo, eleitos mediante sistema proporcional e sufrágio universal, igual e direto, e de representantes eleitos pelas organizações profissionais na forma que a lei indicar.

$\S 3^{\circ}$ - Os Deputados das profissões serão eleitos na forma da lei ordinária por sufrágio indireto das associações profissionais compreendidas para esse efeito, e com os grupos afins respectivos, nas quatro divisões seguintes: lavoura e pecuária; indústria; comércio e transportes; profissões liberais e funcionários públicos.

$\S 4^{\circ}$ - O total dos Deputados das três primeiras categorias será no mínimo de seis sétimos da representação profissional, distribuído dividindo-se cada uma em círculos correspondentes ao número de Deputados que lhe caiba, dividido por dois, $\underline{\boldsymbol{a}}$ fim de garantir a representação iqual de empregados e de empregadores. O número de círculos da quarta categoria corresponderá ao dos seus Deputados.

Os sindicatos, nestes casos, tinham sido formados mais por interesse político do que econômico, e destarte, o instrumento da convenção coletiva prescrita na lei magna não é desenvolvida, pois apesar de reconhecê-la não a efetiva. Interesses políticos e classistas definem a atuação sindical, supostamente formulada para melhorar a condição do trabalhador, características que são fruto de uma ideologia adaptada a uma economia incipiente cuja classe política tinha sido bastante influenciada pelos ideais liberais do Partido Trabalhista inglês.

As centrais pluralizadas convivem com a unicidade de base (um só sindicato em cada categoria e base territorial), arraigada na tradição e reafirmada pela Constituição de 1988. A unicidade tem persistido a despeito da defesa do plurissindicalismo pelo governo 
federal e parte da Central Única dos Trabalhadores (CUT), em 2002. Reformas trabalhistas estão sendo bastante discutidas na Frente Nacional do Trabalho (FNT). Sindicatos são disputados por centrais de trabalhadores diversas; o resultado tem favorecido as centrais mais dinâmicas, que lutam por uma maior representatividade para incrementar sua força política.

São inúmeros os casos de sindicatos que mudam os vínculos, como o sindicato dos metalúrgicos de Volta Redonda tomado da CUT (Central Única de Trabalhadores) pela FS (Força Sindical) em 1992. O embate das centrais nas disputas pelos sindicatos desfocaliza a luta econômica coletiva que deveria pautar as disputas trabalhistas em prol do aumento do bem-estar dos trabalhadores, reafirmando a vocação política na história dos sindicatos brasileiros que, de certa forma, encontra na política um instrumento mais eficaz de luta contra a implacável imposição econômica que é dada aos países sem capacidade de formação primitiva de capital.

Tal fato se deve às características dos sindicatos de trabalhadores que, em razão das flutuações que vêm sofrendo no implacável processo histórico de peleja pela emancipação político-econômica, acarretaram a falta de uma maior autonomia de muitas agremiações, bem como o desaparecimento de algumas. Com o fortalecimento dos sindicatos efetivados nas regiões mais industrializadas, estes passaram a servir de modelo e referencial aos sindicatos de menor porte alhures. 


\subsection{Sindicalismo brasileiro no regime de exceção (1964-1985)}

Este breve retrospecto histórico abaixo procura situar a nova reformulação dos acordos coletivos, em especial dos contratos coletivos do trabalho no final do período em discussão.

A extensa transformação desenvolvimentista estrutural ocorrida neste período atinge o auge com os denominados "milagres econômicos" cujos custos só viriam à baila muitos anos depois com as altas taxas de inflação e a estagnação do setor industrial, causando todos os tipos de crises financeiras. Uma análise mais acurada de tais "milagres" caracterizou, em ambos os casos, não exatamente uma "dádiva de Deus", mas um fato expropriador, como se constatou, posteriormente, com a realização da taxa de retorno de investimento que não condizia com o montante investido e cujo custo ocasionou crises econômicas diversas com os agravantes, entre outros, do bem-estar social sumariamente precarizado.

A conjuntura econômica mundial da época indica-nos que a base mais importante que caracterizou a formação da Comunidade Econômica Européia foi o desequilíbrio financeiro mundial que possibilitou a formação do mercado europeu de dólares (de "eurodólares"), evidenciando sua determinação de enfrentar a hegemonia norte-americana para reforçar a sua própria.

O contínuo deficit externo estadunidense, a primeira crise do petróleo em 1973 e a injeção de petrodólares, associados à valorização das moedas fortes frente ao dólar, deixaram o mercado de crédito internacional com liquidez anormal, o que possibilitou a entrada de recursos consideráveis durante os últimos governos militares, dando andamento ao processo de substituição de importações, tanto é que se evidenciaram graves desequilíbrios sociais após a frustração da expectativa desenvolvimentista. A utilização de excedentes dos ativos financeiros que fluíram para o Brasil e México fez parte de medidas adotadas pelos governos detentores destes mesmos excedentes, com o intuito de tentar controlar as corporações transnacionais em sua relação de dependência, mas acabaram por precarizar, ainda mais, os graves problemas sociais localizados.

Assim como na medicina não existem milagres e toda cura tem causas biológicas, na economia ocorre o mesmo, pois o fato econômico não deixa de ser um 
aspecto particular de um fato social mais intrincado e variado com o qual mantém interdependência e cuja solução de cura está na harmonização dos inter-relacionamentos sociais com a finalidade de melhorar o bem-estar social como prerrogativa máxima da vida em equilíbrio.

A instauração deste modelo de crescimento para promover o desenvolvimento da industrialização secundária, com a segurança para a reinversão dos capitais externos aqui investidos, do frágil empresariado nacional mais a participação do Estado como feitor econômico, fez com que se formasse o tripé do almejado crescimento; entretanto, revelouse uma falácia: isto que fora aludido como uma grande racionalidade econômica, mostrou-se muito insipiente na dura realidade econômica e social. As multinacionais tinham sido cativadas pela conjuntura altamente favorável à introdução, fixação e expansão de seus conglomerados, principalmente pela mão-de-obra barata e a estabilidade assegurada pelos militares. Com o controle da intimidação exercida sobre o operário somado a outras táticas militares, o governo emprega diferentes formas de repressão aos trabalhadores, tais como o cerceamento da liberdade de organização sindical. Um exemplo foi a constrição do aumento real de salário conforme determinava a legislação de 1965. Ao optar exclusivamente pelos instrumentos autoritários da lei, o governo militar abdicou de qualquer tentativa de legitimar-se frente aos sindicalistas.

De 1968 a 1974, como foi conhecida a fase do "milagre", a expansão da economia manifestou uma rápida aceleração, com a média de $11 \%$ ao ano. A primeira crise do petróleo, de 1973, abrandou o crescimento excepcional, uma vez que importávamos grande parte do petróleo com preços e consumo crescentes. O governo Médici (1969 a 1974) investiu em grandes obras de infra-estrutura, como, por exemplo, a Usina de Itaipu em associação com o Paraguai do então presidente Alfredo Stroessner que geraria 10 milhões de KWs, vislumbrando um grande crescimento econômico. Esta obra, entretanto, prescindiu das necessidades históricas da sociedade brasileira e agravou ainda mais a já péssima distribuição de renda. Os velhos jargões mimetizados de outras culturas foram introduzidos a fim de propagandear as conquistas econômicas, a exemplo de bordões como "Brasil: Ame-o ou Deixe-o!", “Brasil: Potência Mundial!”, demonstrando falta de coerência quanto aos verdadeiros objetivos nacionais, como atestaram as palavras do presidente Garrastazu Médici à época: “A economia vai bem, mas o povo vai mal”. 
O crescimento do PIB foi extraordinário até 1974, com um desenvolvimento econômico florescente, mas demonstrou insustentabilidade por não ter havido domínio real e competência na administração do vultoso montante de capital externo que alavancara a economia, mesmo com a partição vantajosa para a classe produtora transformada, paulatinamente, após as várias crises, em classe rentista. Em razão de suas conseqüências desastrosas, a política econômica mostrou-se insuficiente para atender a um desenvolvimento lídimo cujo detalhamento refletira a dura realidade das demandas sociais, recrudescendo a já péssima distribuição de rendas sem, ao menos, sequer, vislumbrar um possível resgate da grande maioria miserável de trabalhadores.

\section{RIQUEZA NACIONAL}

\section{PARTICIPAÇÃO DA METADE DA POPULAÇÃO MAIS POBRE}

1960
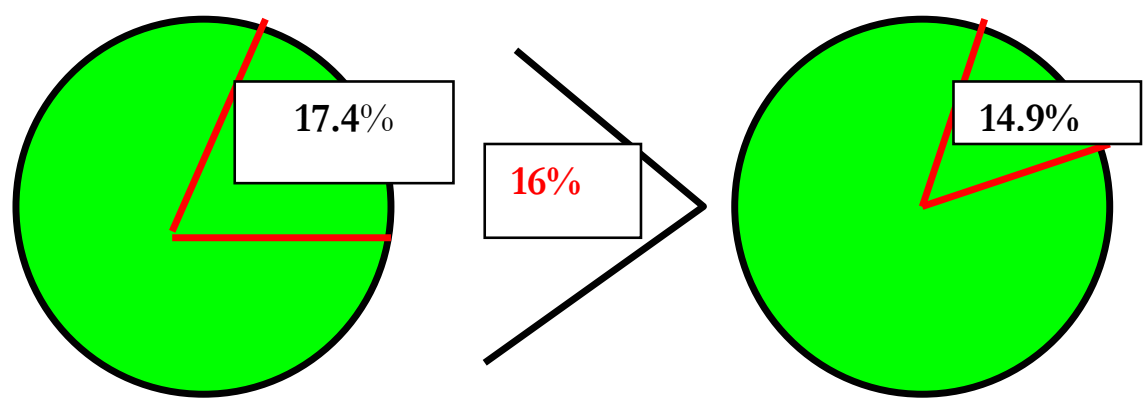

1970

Fonte: IBGE

\section{PARTICIPAÇÃO DE 20\% DA POPULAÇÃO MAIS RICA}

1960

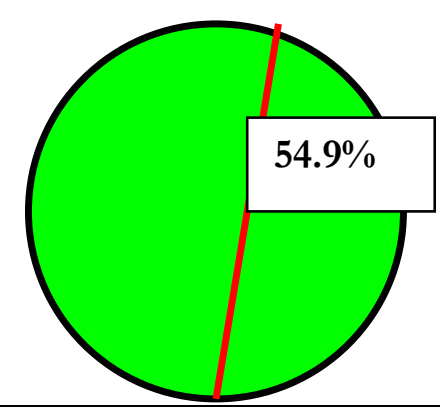

1970
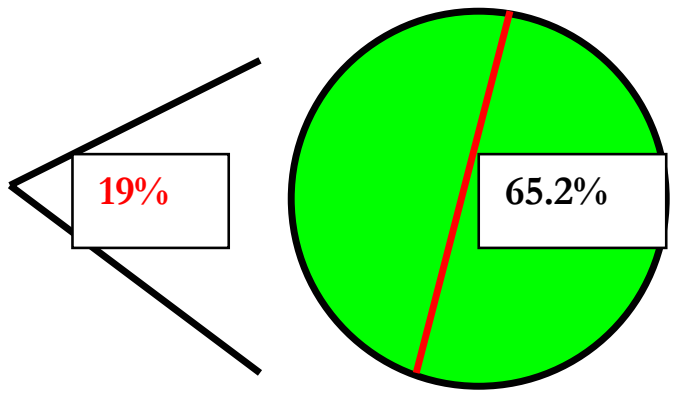

Fonte: IBGE 
Com a modificação da máquina produtiva industrial, o processo direcionou-se para bens de capital intermediário e durável modificando a distribuição da população economicamente ativa (PEA) que migrou do campo, expandiu o setor industrial e construção civil, mas não se fez acompanhar de uma urbanização condizente, o que denota a forma histórica de submissão que o governo acaba, por fim, tendo em relação a outros interesses, sem atentar de maneira mais substanciosa às variáveis de fortalecimento do mercado interno e de agregar maior valor à matéria-prima, com um juízo crítico avaliativo mais intenso na valoração do capital humano que se fortaleceria se houvesse a determinação efetiva e inviolável que um Estado arqui-são deve ter, primordialmente, com o ensino básico e fundamental.

Os diversos setores da indústria, no período do "milagre", passaram a desenvolver progressivamente um crescimento acelerado, especialmente, de bens de consumo duráveis (média de 23,6\%) e bens de capital (média de 18,1\%). A importância da indústria automobilística, que representava a aspiração do movimento desenvolvimentista brasileiro, com taxas anuais de $25,6 \%$, e de eletroeletrônicos de $28 \%$, dinamizava diversos setores de bens de capital, como o de autopeças e serviços interativos da produção automobilística.

A ampliação das relações contratuais individuais trabalhistas com a reformulação do processo produtivo possibilitou o aparecimento de um novo sindicalismo que se pautou por reivindicações e foi duramente reprimido pela ditadura militar, pois a subordinação ao Estado, uma das características deste corporativismo, não mais condizia com o estágio de desenvolvimento sindical que tem acompanhado a dinâmica da industrialização, mesmo a de caráter secundário e acessório. Entretanto, nem o governo e nem a classe empresarial esboçaram uma possível objeção ao modelo de política trabalhista vigente à época getulista.

O Decreto-lei 5.452, de $1^{\circ}$ de maio de 1943, em seu Título VI, na versão original, anunciara o Contrato Coletivo de Trabalho e os dissídios coletivos, com relativa autonomia. Em 28 de fevereiro de 1967, o Decreto-lei 229 introduziu mudanças na CLT, dentre as quais, a eliminação do dissídio coletivo de cunho essencialmente econômico, sendo seu ajuizamento somente permitido quando todas as tentativas de acordo tivessem sido esgotadas, pois a questão a que um CCT tradicional realmente deve se ater é a econômica; destarte, sua instituição foi postergada uma vez que não se admitiam 
discordâncias com a política econômica do governo. A possível reformulação da política econômico-financeira do ainda recente governo militar que pudesse eventualmente atender à demanda salarial dos trabalhadores pela convenção coletiva, poderia ser considerada nula, conforme o artigo 623.

A criação do Fundo de Garantia por Tempo de Serviço (FGTS), em 13 de setembro de 1966 através da lei $5107^{71}$, foi o preâmbulo da flexibilização na estruturação jurídico-trabalhista, pois passou a ser optativa (optante e não-optante) e, destarte, acarretou a perda da estabilidade empregatícia de quem completasse 10 anos de serviços prestados, então em voga. O sonho da casa própria, motivo pelo qual o FGTS investiria em construções de casas para acabar com o problema nacional de falta de moradia, continua, ainda hoje, uma quimera, pois as políticas públicas não se encontram mais tão voltadas à sociedade; em contrapartida, tem prevalecido a ótica do mercado na perspectiva neoliberal.

Em 1976, a rotatividade da mão-de-obra tornara-se significativamente maior para aqueles que tivessem mais tempo de firma: até 5 anos de firma, em média $70 \%$ do pessoal empregado com carteira assinada; até 2 anos, 60\%; e, até 1 ano, $40 \%$.

\footnotetext{
${ }^{71} \mathrm{Na}$ ocasião foi ministrado um primeiro curso sobre os procedimentos do FGTS do qual o autor teve a oportunidade de participar.
} 


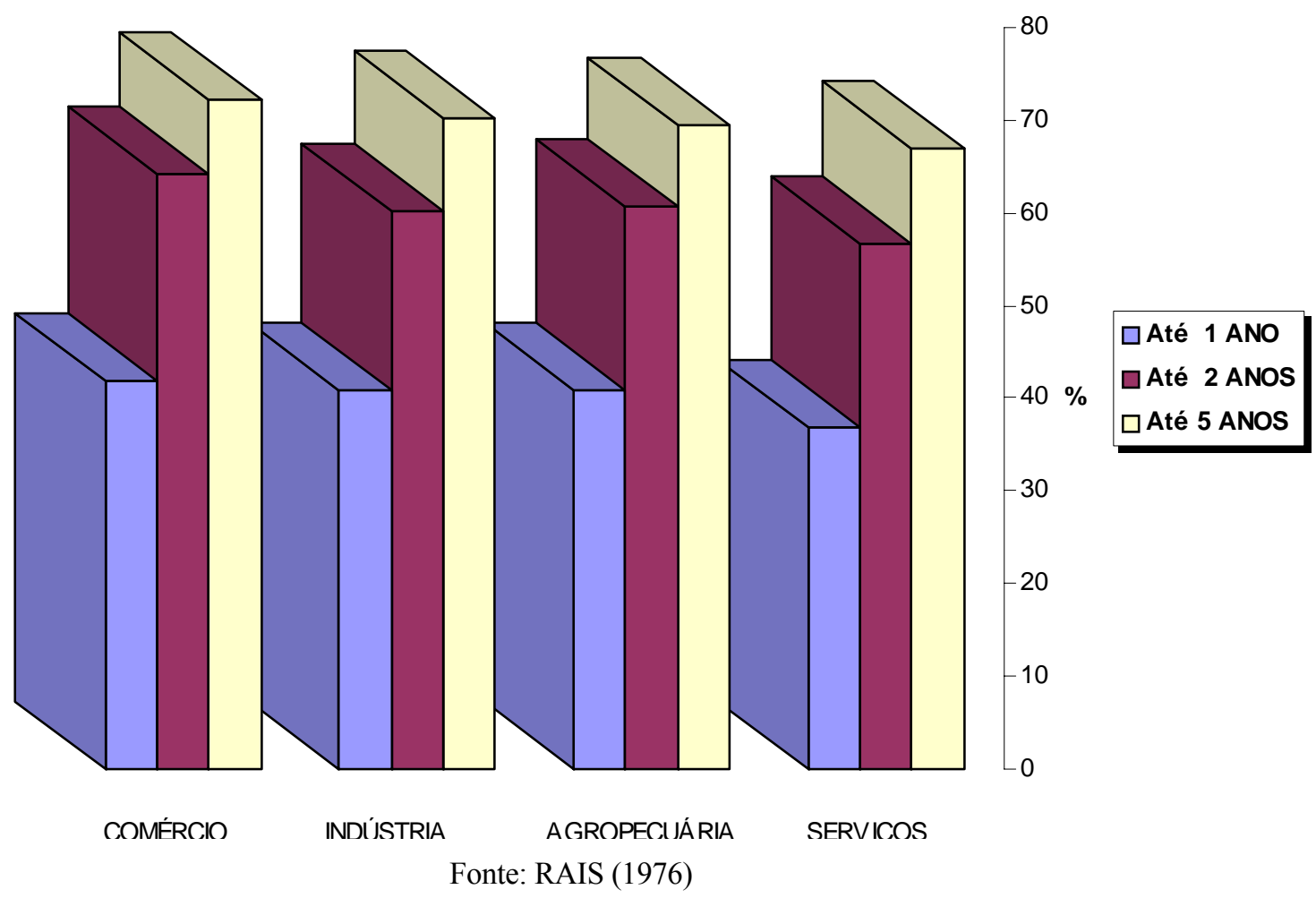

Aspecto bastante perverso e controverso (para quem tem um conhecimento autêntico que o fato de estar presente no cenário dos acontecimentos nos proporciona no desenrolar dos acontecimentos), foi a presença ostensiva de representantes questionáveis da reserva, em termos da execução justa dos objetivos nacionais permanentes conforme preceitos da Escola Superior de Guerra (ESG), dando cobertura, segundo princípios básicos da logística moderna, nos Departamentos de Pessoal de diversas indústrias dos setores mais dinâmicos da economia, como o setor automobilístico ${ }^{72}$.

As dependências que ocupavam as diversas patentes, com unidade de direção, eram sempre em salas muito discretas, mais pareciam dependências de caserna e mesmo estando dentro da mesma secção nunca se sabia exatamente quem era quem, a exposição era mínima e envolta em clima de incognoscibilidade. Na rotina do dia-a-dia as atividades eram centralizadas e diversificadas, delegava-se aos funcionários de confiança em cargos de chefia do departamento pessoal consultas às indústrias congêneres e aventava-se a

\footnotetext{
${ }^{72} \mathrm{O}$ relato a seguir foi fruto da experiência profissional do autor, que teve a oportunidade de presenciar seu "modus operandi".
} 
possibilidade de dispensa de um determinado número de torneiros-mecânicos de ambos os lados. Por intermédio da própria imprensa sindical, ou mesmo pelo eficiente sistema de informações e disciplina de comunicação dentro das próprias multinacionais, as vagas resultantes das dispensas arbitrárias "sem justa causa", eram preenchidas pelos ocupantes das vagas dos outros igualmente dispensados, evidenciando uma grande rotatividade da mão-de-obra. O salário, entretanto, era em média de $25 \%$ a $30 \%$ inferior na nova admissão. Era como matar dois operários com um tiro só. Assim, tiravam-lhes a segurança da estabilidade empregatícia e diminuíam-se os custos do trabalho num arranjo digno de uma maestria internacional que vem, justamente, caracterizar a intencionalidade que, em grande parte, o capital, mormente o forâneo, tem nas suas históricas relações com os trabalhadores desde a época da industrialização. Os problemas advindos de tal ato, agora, não cabiam mais à competência do departamento de pessoal, ou seja, a alçada agora era governamental, pois um Estado mais autêntico e autônomo deveria estar bem mais preparado para a defesa dos seus trabalhadores!

Tais constrangimentos ajudaram a criar um clima de revolta nos trabalhadores que se insurgiram com um "basta" para uma situação tão pitoresca, que representara a aliança daqueles oficiais da reserva com as empresas multinacionais na troca de "listas negras" de empregados mais conscientes deste descaso e de informações de ações acobertadas nas empresas e sindicatos, que teve como resultado milhares de demissões e centenas de prisões com participação exaustiva da polícia política, o que vem caracterizar as alianças deploráveis do poder. Uma interação forte e acintosa foi estabelecida entre Volkswagen, Scania, Mercedez, Chrysler e outras. Em muitos casos, as interações foram tão florescentes que, posteriormente, foram facilitados os entendimentos negociais para levar a efeito as fusões, de diversas formas e objetos, entre várias daquelas empresas multinacionais. É estarrecedora a capacidade do capital na defesa intransigente de sua prerrogativa real de acumulação, que se torna ainda mais perversa no mundo global de acintosa concorrência e desprovido de regras morais e éticas, em detrimento dos valores humanos de trabalho e de maior justiça social e ambiental.

Nos casos mais extremos, segundo a ótica de segurança das multinacionais, de preeminência das suas finanças patrimonialistas sobre as necessidades fundamentais e descasos aos trabalhadores, quando as determinações da matriz superavam as possibilidades locais, foram realizados diversos atos entre 1977 a 1980, cuja deliberação 
das atividades intimidadoras partia do próprio efetivo aéreo militar brasileiro, tão bem testemunhado em várias ocasiões no estádio de Vila Euclides em SBC onde se desenrolaram as reuniões do sindicato dos metalúrgicos de São Bernardo do Campo e Diadema, hoje "sindicato do ABC".

Foi a partir de 1977, diante desta nova dinâmica político-econômica, que as pressões externas, utilizando entre outras técnicas refinadas de psicologia comportamental, imiscuíram-se de maneira mais taxativa na defesa de interesses prócorporações privadas globais, delineando e promulgando as incipientes táticas neoliberais de enfraquecimento político institucional. Questões privadas que não deveriam prevalecer ao interesse público tornaram-se mais contundentes no sentido de facilitar a incapacitação do funcionamento adequado das instituições públicas responsáveis pelo tão almejado desenvolvimento autêntico de crescimento social-econômico.

A indústria automobilística esteve na vanguarda das novas relações trabalhistas com as negociações por setor (câmaras setoriais) entre empregador e empregado, flexibilizando a rigidez normativa das leis trabalhistas por meio de conciliações coletivas, adaptando-se à imposição capitalista contemporânea de acirrada competitividade frente aos mercados externos.

O aparecimento da "central sindical" abriu caminho para a organização horizontal, descaracterizando a obrigatoriedade da representação imposta pela lei. Estas metamorfoses, entretanto, apenas abrandaram a preeminência corporativista incrustada no movimento sindical desde a época de Vargas.

A centralização de grandes quantidades de recursos nas mãos do governo, da burguesia industrial e de agricultores latifundiários fez-se à custa de riquezas não compartilhadas pela população trabalhadora que as produziu.

Os responsáveis pela segurança das empresas multinacionais ligados a diferentes estratégias de intimidação, violência e proibição unilateral tidas como injustas pelo código dos direitos trabalhistas da Organização Internacional do Trabalho (OIT), são condizentes com a tímida burguesia nacional, sugestionada e acumpliciada com os interesses privados corporativos multinacionais. A elite nacional tem facilitado, com um mínimo de condicionantes, as transferências externas que poderiam gerir mais reinvestimentos, proporcionando um maior bem-estar social que adviria se tais transferências fossem feitas de maneira mais justa, de acordo com os verdadeiros 
objetivos nacionais de progresso econômico sustentável com o conseqüente desenvolvimento social. $\mathrm{O}$ que se verifica nestes casos tem sido um verdadeiro marasmo econômico do qual nós não conseguimos nos livrar desde a década de 1980.

A proibição de greves e o excessivo rigor na formulação salarial tiraram a capacidade de negociação dos sindicatos até 1977, quando um novo sindicalismo da industrialização secundária fez-se ouvir. Foi a iniciativa dos profissionais mais especializados, denominados de aristocracia operária, que iniciaram o movimento com a parada das máquinas, na primeira greve pós 1964, que conscientizou toda uma classe ao dar um basta à superimposição capitalista e seus coadjutores que procuravam preservar o não reconhecimento de autênticos direitos dos trabalhadores.

Quanto às greves de 1979 e, principalmente, a do dia $1^{\circ}$ de abril de 1980, a de 41 dias com 200.000 grevistas, podia-se constatar in loco a obrigação legal e profissional com que agiu o Tribunal Regional do Trabalho (TRT) no primeiro instante, declarando a greve legal, mas após telefonemas exaltados dos encarregados de segurança no departamento pessoal que saíam apressadamente para reuniões alhures, um fato novo ocorreu: um novo pronunciamento do mesmo TRT fez-se ouvir dois dias depois, tempo suficiente para os arranjos institucionais e reflexões mais profundas que culminaram na ilegalidade da greve, dando azo a diversas interpretações de ordem moral de qual teria sido o fato novo em que incorreram aqueles juízes para aquela nova determinação!

Como já estava previsto pela estratégia empregada por planejadores hegemônicos - exímios conhecedores dos caminhos com que o poder instiga a mente humana -, as lutas que travariam os líderes dos sindicatos fortes entre si descaracterizariam os desfechos de exercícios coletivos que pudessem debilitar o caráter tradicional com que o poder capitalista tem atuado na defesa intransigente de seus desígnios, no sentido de divulgar o novo sindicalismo como força atuante em todos os segmentos da sociedade. A constante diminuição na densidade de sindicalizados nãopúblicos vem caracterizar a prostração e a alienação em que a maior parte dos trabalhadores julga estar inserida.

O que se denominou "Oposição sindical” apareceu juntamente aos incipientes movimentos sociais do país que se insurgiram no momento da propalada abertura política que se intensificara a partir do governo do ex-presidente Ernesto Geisel (1974-1979), responsável pela distensão rumo à abertura democrática. 
As autoridades diplomáticas dos países movidos por maiores interesses capitalistas estiveram preocupadas com a formação dos quadros sindicais oriundos daqueles movimentos sociais, entre eles, as Comunidades Eclesiais de Base (CEB), Juventude Operaria Católica, Ação Católica Operária, trabalhadores autônomos e exlideranças contrárias do que então era a prática sindical.

Basta lembrar que, de 1977 a 1980, os inúmeros cursos e congregações incógnitas nos núcleos ligados à Igreja Católica de educação popular aos trabalhadores, principalmente em relação às Comunidades Eclesiais de Base (CEB), foram alvos de monitoramento das autoridades que representavam os grandes interesses capitalistas. Muitas destas "autoridades diplomáticas" faziam referência à localização da Praça dos 3 Poderes em Brasília, não na sua posição geográfica real, mas na confluência dos Consulados da União das Repúblicas Socialistas Soviéticas, do Norte-Americano e da sede da instituição religiosa católica denominada Conferência Nacional dos Bispos Brasileiros (CNBB). 


\subsubsection{A tácita persuasividade estratégica}

O Instituto Cultural do Trabalho (ICT) foi fundado em 24 de abril de 1963, como sociedade civil, e declarado de utilidade pública pelo decreto executivo estadual SP, número 42.099, de 26.06.1963, emanado pelo Palácio do Governo do Estado de São Paulo, cujo governador era o dinâmico Sr. Adhemar Pereira de Barros, na época em que o governo norte-americano, através de suas várias agências, promovia propaganda contrária ao governo de João Goulart devido, entre outros motivos, a algumas nacionalizações na área petroleira e à nova lei de remessas de lucros (setembro de 1962) mais favorável ao Brasil, mas que, ao mesmo tempo, enroupava os governos dos Estados de maior expressão político/econômica com o intuito de desestabilizar o cenário político desfavorável aos anseios exclusivos dos empreendimentos corporativos. Os notórios relacionamentos políticos e militares com o governo norte-americano eram mais efetivos desde a Segunda Guerra Mundial, pois, ao término desta, a maior parte dos oficiais brasileiros confraternizou-se com oficiais da Academia Nacional de Guerra, a "National War College", em visitas prolongadas a Washington D. C., e vice-versa. ${ }^{73}$

O IPES (Instituto de Pesquisas e Estudos Sociais) e o IBAD (Instituto Brasileiro de Ação Democrática) ${ }^{74}$ foram também instituições importantes na persuasividade estratégica. O IPES foi fundado em 1961 e o IBAD em 1959 e eram financiados por empresários brasileiros e estrangeiros. Tais instituições ligadas a organismos internacionais eram providas de uma complexa interligação e de um vigoroso planejamento estratégico, tendo estes sempre estado presentes na vida nacional em momentos delicados de transição política. Estes órgãos agiam, outrossim, em estreita e velada sintonia com orientações forâneas com o intuito de manter o status quo que lhes era próprio, visando prevenir seus amplos interesses econômicos/financeiros que também

\footnotetext{
73 O ICT fazia parte do programa de ex-presidente Kennedy denominado "Aliança para o Progresso", sediado, primeiramente, na rua Líbero Badaró, 293, cj. 24C e, depois, na Alameda Cleveland e na Alameda Dino Bueno, 475, São Paulo, Cep 01217, Capital, caixa postal 1610, endereço telegráfico "FREELAB" e telefone 221-8033. Era o instituto que promovia palestras e cursos regionais para os membros de sindicatos e fazia parte do complexo IPES/IBAD.

74 "A elite orgânica do IPES/IBAD constituiu-se num verdadeiro aparelho de classe, uma poderosa organização com formidáveis recursos e capacidade humana e material para realizar uma ação política, ideológica e militar de real envergadura nas áreas-alvo: sindicatos urbanos e rurais, a classe trabalhadora industrial do sudeste e sul, o movimento estudantil, as classes médias, hierarquia da igreja, o legislativo e os militares”. In: DREIFUSS, René. Op. cit., p.140-147.
} 
lhes garantia a preponderância local, sendo, contudo, submetidos à hegemonia capitalista de ação global, da qual foram fiéis e subservientes.

A partir do crescimento dos movimentos sociais reivindicatórios, a começar pelo dos trabalhadores rurais em Pernambuco e as insurgentes Ligas Camponesas nos anos 60, a participação de sindicalistas urbanos e estudantes universitários têm sido diretamente proporcional à articulação da classe mais rica, inculcada de valores elitistas, no sentido de impedir tais manifestações que, indubitavelmente, poderiam acarretar sérios aborrecimentos à exclusividade dos seus interesses em consonância com as orientações capitalistas internacionais. Foi justamente nos anos de 1961 a 1963 que o sindicalismo brasileiro mais autêntico logrou maior intensificação de suas atividades, com um aumento de $243 \%$ de greves em relação ao governo JK (1956/1961), sob a liderança da Confederação Geral dos Trabalhadores (CGT).

O ICT promovia o "Curso Básico de Liderança Sindical” com duração de 90 dias, num total de 360 horas, e os Seminários Regionais de uma ou duas semanas, num total de 40 horas. Foram feitos cursos e seminários em todo o Brasil exceto no estado do Acre e nos remanescentes territórios federais da época. A ordem de prioridade era de acordo com a importância econômica do sindicato e a urgência, no que diz respeito aos interesses ideológicos mais revolucionários, ou nacionalistas mais exacerbados, assim distribuídos no período de 1963/65:

CURSOS E SEMINÁRIOS REALIZADOS PELO ICT - 1963/1965

\begin{tabular}{|l|c|c|c|}
\hline Estados & Seminários & Cursos & Sindicalistas \\
\hline São Paulo & 31 & 65 & 810 \\
\hline Rio Grande Sul & 15 & 18 & 473 \\
\hline Paraná & 6 & 17 & 183 \\
\hline Pernambuco* & 5 & 11 & 162 \\
\hline Minas Gerais & 4 & 5 & 102 \\
\hline Guanabara** & 4 & 11 & 118 \\
\hline Bahia & 3 & 11 & 67 \\
\hline Ceará & 2 & 8 & 2018 \\
\hline \multicolumn{1}{|c|}{ TOTAL } & 70 & 146 & 103 \\
\hline
\end{tabular}

Fonte: Anotações pessoais.

* Abrangia Seminário especial de 30 dias com 160 horas, desde que fora criado no Recife o ICT/Regional quando, em março de 1965, organizou o $1^{\circ}$ Seminário Regional para 38 sindicalistas rurais. Em 1965, a Federação dos Trabalhadores Rurais de Pernambuco (FETAPE), com subsídios do IADESIL (Instituto Americano para o Desenvolvimento do Sindicalismo Livre), formulara instituir centros culturais do trabalho nas cidades de Carpina, Goiana, Garanhuns e outras com maior influência das Ligas Camponesas. ** Abrangia o Estado do Rio de Janeiro. 
Neste período inicial, entre os cursos promovidos e outras atividades, foram envolvidos cerca de 2500 sindicalistas. O objetivo oficial, no NE brasileiro, era o de atender às precárias condições econômicas e sociais que predominavam desde longa data, sem, contudo, ter conseguido reverter aquele quadro deu azo a interpretações contraditórias quanto ao seu verdadeiro objetivo. O crescimento das associações de trabalhadores rurais nas áreas canavieiras, principalmente no estado de Pernambuco, denominadas de Ligas Camponesas, tiveram por objetivos afirmar os direitos trabalhistas no campo e legitimar a posse da terra para o trabalho e sustento familiar.

Essas Ligas foram os atores principais na formação da CONTAG (Confederação Nacional de Trabalhadores na Agricultura) que defendia uma reforma agrária ampla, na expectativa de que fossem atendidas as suas reinvindicações, de modo que os meios de comunicação internacionais intitulavam-na de pró-comunista ou maoísta, mas cujo verdadeiro rótulo seria a defesa intransigente de interesses exclusivos do capitalismo internacional e seus colaboradores locais.

O ICT funcionou nos moldes de como foi idealizado, até meados de 1988, envolvendo cerca de 74.000 sindicalistas, dos quais cerca de 3.200 com cursos de longa duração e centenas de sindicalistas que foram para os EUA. Atualmente, um outro ICT, diferente do modelo anterior, funciona atrelado à Central Geral dos Trabalhadores (CGT) ${ }^{75} \mathrm{O}$ ICT recebia recursos diretamente do The American Institute of Free Labor Development (AIFLD), Instituto Americano para o Desenvolvimento do Sindicalismo Livre (IADESIL), diretamente ligado à AFL-CIO, subsidiado pela United States Agency for International Development (USAID), ou Agência dos Estados Unidos para o Desenvolvimento Internacional (AEUDI), com vistas à defesa da política e aos extensivos interesses corporativos norte-americanos, eventualmente ameaçados pelo comunismo e pelo castrismo e, com isto, poder ter um maior controle dos maiores movimentos trabalhistas, de acordo com a estratégica política internacional trabalhista (Foreign Labor Affairs) do Departamento de Estado.

O Instituto Americano para o Desenvolvimento do Sindicalismo Livre (IADESIL) foi originalmente concebido para treinamento de sindicalistas ligados aos setores de energia/comunicações desde os anos 50, mas foi fundado oficialmente em

\footnotetext{
${ }^{75}$ A partir de 21.07.2007 denomina-se União Geral dos Trabalhadores que foi o resultado da associação das ex-centrais sindicais CGT, Central Autônoma dos Trabalhadores (CAT), Social Democracia Sindical (SDS) e vários outros sindicatos independentes.
} 
Agosto de 1961, época em que aquelas multinacionais tinham investido montantes significativos em ativos permanentes na América Latina. Os sindicalistas escolhidos eram enviados para o centro de treinamento da Communications Workers of América (CWA), em Front Royal Institute (Virginia, EUA), para períodos de até 9 meses de doutrinamento, com direito à pensão completa. O curso de "Democracia Sindical Livre" era conservador, anticomunista e pró-comércio e seu propósito fundamental era o de poder resgatar o controle e monitoramento dos sindicatos latino-americanos.

Os dados com referência aos números de participantes são muito contraditórios, pois, segundo alguns autores, esta cifra envolvera cerca de 200.000 sindicalistas provindos da América Latina, ${ }^{76}$ mas a AIFLD, no seu relatório anual, quando comemorara os 26 anos de atuação (1962-1988), informou um total aproximado de 490.000 sindicalistas latino-americanos. Do Brasil participaram cerca de 74.000 sindicalistas (14\% do total) nos cursos e seminários locais e, aproximadamente, 680 nos cursos do Front Royal Institute e George Meany Center em Washington D. C., e cerca de 30 economistas ligados mais diretamente à área trabalhista, em universidades americanas. Estes dados refletem satisfatoriamente o universo brasileiro envolvido no esquema, pois que, concorrendo quase sempre de maneira pouco explícita, tais atitudes carregam no âmago um planejamento estratégico hegemônico global dissimulado.

As atividades têm sido subsidiadas, com diferentes configurações, pelo programa criado no governo Reagan, em 1983, a National Endowment for Democracy NED (Doação Nacional para a Democracia), ligada à American Chamber of Commerce, cujo montante aproximado de US\$ 30 milhões $^{77}$ serviu para desenvolver um pressuposto modelo democrático de sindicalismo livre, cujas bases, mesmo nos EUA, são dominadas pelas grandes firmas multinacionais e cujas lições devemos ter sempre em mente na análise da subjugação intrépida em que sempre estiveram envolvidos trabalhadores em lutas notáveis para as conquistas de bem-estar social.

O NED, de dotação orçamentária votada pelo Congresso americano, tem financiado, assessorado e assistido não só sindicatos, mas partidos políticos, campanhas políticas, grêmios estudantis, meios de comunicação, algumas ONGs, agências de publicidade e, enfim, todo tipo de organização ou pessoas com atitudes anticomunistas e pró-capitalistas com a finalidade de inteirar-se dos fatos. Este tem atuado nestes

\footnotetext{
${ }^{76}$ John Ranelagh, The Rise and Decline of the CIA, Simon \& Schuster, 1987.

${ }^{77}$ Dados tendenciosos e não confiáveis.
} 
propósitos de maneira mais aberta e adversa aos métodos furtivos das diversas agências de inteligência, mas age sempre de modo coadjuvante. Inicialmente, o ICT e, posteriormente, o NED desenvolveram um amplo programa que foi denominado "leader grantee" (líder beneficiário), que envolvia os principais segmentos da sociedade, mormente aqueles mais nacionalistas/progressistas que pudessem vir a criar a capacidade de intervir desfavoravelmente nos interesses que envolviam um enorme montante de ativos permanentes e financeiros que os grandes conglomerados norte-americanos haviam investido no país.

Os líderes desses segmentos haviam sido enviados para uma completa, bem estruturada e planejada visita estratégica aos EUA, nesta ordem de prioridade:

1. Jovens políticos promissores;

2. Acadêmicos brilhantes: ( $1^{\circ}$ Economia, $2^{\circ}$ Política, $3^{\circ}$ Direito $)$; antes de 1985 , a prioridade era outra: ( $1^{\circ}$ Política, $2^{\circ}$ Economia, $3^{\circ}$ Direito);

3. Lideranças na área trabalhista;

4. Militares destacados;

5. Líderes religiosos progressistas.

O estratagema possui a finalidade de envolver e criar laços cordiais entre os diversos atores procurando identificá-los com a submissão à ideologia proposta. Para tal objetivo, usavam diversas técnicas, dentre as quais, as psicológicas de comportamento pavlovianas $^{78}$ que foram tão bem desenvolvidas e refinadas por Skinner ${ }^{79}$ e Watson ${ }^{80}$. Tem tido sucesso em todas as áreas exceto quanto a alguns líderes religiosos mais progressistas que, munidos de um severo compromisso ideológico social não se deixavam conduzir pelo indeterminismo que caracteriza as motivações que levam o sujeito a desenvolver certas ações e a todo o momento não deixavam de reflexionar o conteúdo veiculado. Haja vista os estreitos relacionamentos com os atores-chave para o

\footnotetext{
${ }^{78}$ Ivan Pavlov (1849-1936). Fisiologista russo, vencedor do Prêmio Nobel em 1904. Desenvolveu a concepção do reflexo condicionado, que trata experimentalmente dos estados e processos mentais dando respaldo ao Behaviorismo.

${ }^{79}$ Skinner, B. F. (1904-1990). Psicologista norte-americano. Desenvolveu o behaviorismo cujo corpo teórico é especifico da psicologia experimental. A conversão do comportamento que advém da psicologia de aprendizagem é centrada nos reflexos consolidados, donde se determinam quais os que devem ser estimulados ou amainados.

${ }^{80}$ Watson, John B. (1878-1958).Psicologista norte-americano pioneiro da teoria psicológica comportamental e criador do Behaviorismo.
} 
desenvolvimento daquela estrutura e cujos laços culturais estão bem consolidados na tentativa de perenizar o modelo apregoado.

Este programa tinha sido orientado através da vasta rede de comunicação dos diversos institutos e centros internacionais ligados à AFL-CIO, com o propósito de formar correligionários com uma visão coadjutora tripartite entre empresas, governo $\mathrm{e}$ trabalhadores e, mais contemporaneamente, com ênfase nas organizações sociais:

- $\quad$ The American Institute for Free Labor Development (AIFLD), com operações na América Latina e Caribe, criada em 1962;

- African-American Labor Center (AALC), com operações em vários países africanos;

- $\quad$ Asian-American Free Labor Institute (AAFLI), com operações em cerca de 30 países na Ásia e Pacífico;

- $\quad$ The Free Trade Union Institute (FTUI), criado em 1977, com operações nos países europeus.

No período político do ex-presidente Ronald Reagan, Lane Kirkland elegera-se presidente da AFL-CIO (1979) e era tido como inexpressivo no que concerne às experiências das verdadeiras lutas pró-sindicato de trabalhadores, mas com grande afinidade nas relações internacionais, cujo título de "diplomata das relações internacionais do trabalho" seria mais apropriado, pois foi nesta época que foram traçadas estratégias de uma maior interação com os sindicatos do mundo inteiro através de seus diversos institutos internacionais. O destaque tem sido a imperatividade dos agentes, no sentido de fazer prevalecer a ideologia constante do manual prevaricador, na qual as várias nações com grandes investimentos multinacionais viam-se envolvidas perante os alegados perigos comunista e castrista, mas que na realidade tem envolvido setores econômicos hegemônicos que têm caracterizado a luta pelo poder.

Toda esta estratégia tinha tido o objetivo de favorecer um ambiente propício a investimentos globais em razão de injunções políticas e econômicas na subordinação à propalada democracia. Como a manipulação dos sindicatos pelos socialistas já tinha sido, desde 1929, refreada nos EUA, o governo estava persuadido de que os demais governos do ocidente, em que o povo exerce a soberania, estavam prestes a serem subjugados pelo alegado "perigo vermelho", mas foi após a $2^{\mathrm{a}}$ grande guerra mundial e usando todos tipos 
de subterfúgios, que pusera em prática uma rede de institutos internacionais, ligados aos sindicatos, dispersos em grandes áreas de interesse e interligados por eficiente sistema de comunicação, contando com a preponderância dos serviços escusos prestados in loco pelas várias agências nos diversos distritos consulares.

Enquanto isso, a partir de 1955, os próprios sindicatos estadunidenses enfraqueciam-se com perdas significativas na densidade de seus membros, bem como na sua tradicional força de barganha nas negociações coletivas, mas a questão principal tem remanescido controversa junto aos trabalhadores estadunidenses no chão de fábrica: que relevância estas operações, nos quatro institutos internacionais entre outros, poderiam ter para o próprio trabalhador norte-americano e seus sindicatos locais?

A AIFLD tinha conduzido este processo de maneira delével no sentido de favorecer os interesses econômicos dos trabalhadores estadunidenses quando assegurara matéria-prima e expansão do mercado já dentro de uma visão global de um processo de produção, às custas da ideologia proposta de sindicalismo livre, entre outros, aos trabalhadores latino-americanos.

A partir do começo dos anos 70 do século passado, o acirramento da competição internacional promovida pela idéia incipiente da comunidade européia e um Japão emergente, fez com que os empregos dos trabalhadores estadunidenses, devido ao seu alto custo, começassem a emigrar para outras paragens. Esta característica é própria de culturas dominantes que, após crescimento vertiginoso, tem se caracterizado pela ambição desmedida e desequilibrada, pois o seu mundo torna-se pequeno demais e aquilo que já havia sido aplicado aos trabalhadores norte-americanos deveria, em princípio, ser aplicado aos outros trabalhadores, como forma de assegurar a ampliação dos interesses capitalistas globais.

A AIFLD tem recebido concessões significativas do NED, de 1994 a 1996 e totalizou US\$ 2.5 milhões ${ }^{81}$ para o propósito específico de doutrinação dos sindicatos do terceiro mundo, no sentido de oporem-se às nacionalizações das companhias americanas e, com isso, promoverem os investimentos externos como parte de táticas hegemônicas na contextualização neoliberal. A partir de 1997, a AIFLD encerrara suas atividades ativas depois de quase 40 anos de lutas, e o presidente da AFL-CIO John Sweeney reorganiza as

81 Dados não confiáveis e tendenciosos. 
operações internacionais através da Central Americana de Solidariedade ao Trabalhismo Internacional (CASTI), ou "Solidarity Center".

As condições da conjuntura política/econômica brasileira, em 1975/1980, eram adequadas para uma reformulação geral no quadro dos líderes sindicais tradicionais ao modelo corporativista, bem como na estruturação de uma alternativa que pudesse satisfazer o governo e os empresários.

As proposições ideológicas de Samuel Gompers, ${ }^{82}$ pró-modelo sindical norteamericano, como parte de um amplo programa global, têm tido traços mui característicos na sua implementação: o sindicato não é visto como uma associação para defesa e coordenação de seus interesses profissionais, mas como mais uma instituição sujeita às regras de mercado; o pressuposto é o de que o sindicato de trabalhadores deve abster-se de uma maior participação política; a ênfase recai na figura da negociação coletiva como forma de conciliar o antagonismo de interesses embutidos nesta relação.

Momentos históricos díspares configuraram as tentativas de implementação do modelo de relação trabalhista contratual coletiva, mais própria para a cultura anglosaxônica, anfitriã da industrialização, com toda a sua tradição histórico-cultural, mas que não se coaduna com os interesses dos trabalhadores de países dependentes de tecnologia e capital, caracterizados por uma industrialização secundária e acessória, em que as variáveis são distintas daquelas pelas quais se originaram. As experiências diferentes no processo histórico da formação cultural-moral norte e latino-americanas, podem assim, ser distinguidas e caracterizadas genericamente:

\section{América Anglo-Saxônica}

Protestantismo. Extremamente devotada aos bens, valores e prazeres materiais. Destino manifesto, desenvolvimento das qualidades conterrâneas, superioridade, crescimento, domínio, evolução, prosperidade e independência. Não privilegia aquilo que é comunitário em benefício do individual. Frieza de caráter audacioso e enérgico etc.

\footnotetext{
${ }^{82}$ Fundador e presidente da American Federation of Labor (AFL). "Punir seus inimigos e recompensar os amigos". "Vencer para Vencer" (Win to win), "Sempre Mais" (More).
} 


\section{América Latina}

Catolicismo. Expunge o individualismo em favor do comunitarismo. Menospreza o orgulho e a ambição. Conflitos, dependência e fragmentação ocasionados pela falta de autonomia, firmeza e sobrelevação aos seus valores. Dependência econômica que se caracteriza pelo monopólio central e as diferenças de preços e elasticidade de bens exportados em contraste com os bens importados, resultando tendência decrescente na receita dos produtos exportados e tendência crescente na receita para os produtos importados etc.

Merece atenção especial, quanto aos objetivos e resultados de longo prazo, a análise dos fatos históricos que envolvem estas organizações trabalhistas internacionais, pois agregam uma antiga questão de economia política que é a defasagem que pode existir entre uma teoria e uma realidade; esta, quanto ao enfraquecimento institucional do governo capaz de políticas de preservação do patrimônio nacional; e, aquela, de doutrinas condizentes aos interesses da hegemonia global que domina os grandes países capitalistas.

Advinda da Confederação Interamericana de Trabalhadores (CIT) que se transfigurou numa nova entidade que foi fundada no México em janeiro de 1951, a InterAmerican Regional Organization of Workers (IAROW), traduzida por Organização Interamericana de Trabalhadores (ORIT), faz parte da International Confederation of Free Trade Unions (ICFTU), traduzida por Confederação Internacional de Organizações Sindicais Livres (CIOSL), com sede operacional na Europa, situada na cidade de Bruxelas. A partir de primeiro de novembro de 2006, em um congresso na cidade de Viena, a ICFTU fundiu-se com a World Confederation of Labour (WCL) e formaram a International Trade Union Confederation (ITUC) com a finalidade de discutir o impacto da globalização, tratando de assuntos como, por exemplo, fusões corporativas nas produções transnacionalizadas e as dificuldades de controle, empresas e sindicatos globais com enfoque no equilíbrio necessário da relação capital versus trabalho submetida à dominante do sistema econômico hegemônico vigente. Este abrange todo o hemisfério ocidental e possui entidades especializadas em todos os continentes, sendo que alega possuir aproximadamente 158 milhões de afiliados em cerca de 150 países.

A importância aparente de suas políticas tem insidido na adequação de propósitos do sindicalismo livre democrático, alentando as organizações sindicais nas 
suas ações conjuntas pró-modelo teórico exemplar de sindicalização a partir de modelo desenvolvido por influências da grande central norte-americana AFL-CIO, concorrendo na América Latina para o exercício de ações de domínio com a Confederação Latino Americana de Sindicatos Cristãos (CLASC), ${ }^{83}$ que desaprovara o pan-americanismo sindical referenciado pela ORIT, mas ambas intentando desalentar modelos sindicais idealizados pelo comunismo.

As organizações internacionais mais ligadas à ambição capitalista dos grandes conglomerados têm tido um olhar inquietante quanto aos sindicatos nacionalistas mais exacerbados e procuram norteá-los paulatina e inquebrantavelmente, de modo a não favorecer um questionamento desvantajoso aos seus vultosos interesses.

A localização geográfica de suas sedes ubíquas, flexíveis e mutantes tem estado sempre relacionada com o clima político do país receptor e seus interesses estratégicos globais envolvidos nestas operações. A sede da ORIT funcionou em Havana (Cuba) desde sua fundação no México em 1951/1961, Ciudad de México de 1961/1989, Caracas de 1989/2006, e desde 10 de abril de 2006, na cidade de São Paulo por pedido efetuado durante o XVI Congresso Continental Ordinário de CIOSL/ORIT, em 20 de abril de 2005 na cidade de Brasília, pelas três Centrais Sindicais, que agora fazem parte da nova direção: Central Única de Trabalhadores (CUT), Força Sindical e Confederação Geral dos Trabalhadores (CGT).

Nada mais oportuno que estar presente na arena, no palco das decisões sobre o futuro dos rumos das reformas econômicas, políticas e trabalhistas. A falta de um consenso entre os trabalhadores é uma prova cabal de que os verdadeiros interesses dos mesmos não estão sendo devidamente considerados; o clima de muita incerteza e desinformação que paira no ar tem uma logicidade inconteste de tutela que as forças capitalistas em conflito de interesses neocoloniais disputam entre si de maneira quase imperceptível, mas sempre com resultados no longo prazo, de precarização dos legítimos valores trabalhistas tão duramente conquistados, haja vista a situação da maioria dos

83 Fundada em 1954 e advinda da Confederação Internacional dos Sindicatos Cristãos (CISC) com inspiração católica apostólica romana. Foi a sua orientação revolucionária determinada no seu $3^{\circ}$ Congresso no Equador (1959) que deliberou a inquietação nos capatazes que representam a hegemonia capitalista. A partir de 1968, passou a se chamar Central Latino-Americana de Trabalhadores (CLAT). De pouco mais de 20 milhões de sindicatos latino-americanos em 1980, conseguiu arregimentar somente cerca de 5\% com sua proposta de solucionar os problemas sindicais através de uma $3^{\mathrm{a}}$ via. A partir de uma maior e incisiva consolidação da doutrina neoliberal, está havendo uma tendência de conciliação entre CLAT e ORIT no sentido de resguardar os direitos humanos e sindicais, cada qual dentro de seus objetivos. 
trabalhadores latino-americanos nas apregoadas lutas democráticas e a importância dos resultados da análise histórica feita de maneira imparcial e objetivando a valoração do trabalhador consciente, ou seja, a situação da maior parte dos trabalhadores, em mais de meio século de atuação, que vem sendo paulatinamente deteriorada.

Segundo estudo efetuado pelo Prof. Dr. André Lafontant Joseph, membro do sindicato dos professores do Haiti, na sua obra Le Mouvement Syndical Haitien, a ORIT encorajou mais de uma dezena de organizações trabalhistas a formarem a Coordination Syndicale Haitienne (CSH) que teve papel preponderante na derrocada do presidente Jean-Bertrand Aristide, eleito democraticamente em 1990 e que contava com o apoio de $70 \%$ da população haitiana. Fatos históricos em diversos locais e já comprovados não sustentam dúvidas algumas quanto ao envolvimento de entidades trabalhistas nas novas configurações governamentais de acordo com os amplos interesses econômicos embutidos em tal relação. Prática de interferência muito efetuada pelos governantes ianques na configuração das relações trabalhistas, também muito suscetível às prerrogativas do capital, em detrimento dos verdadeiros valores trabalhistas, humanos e ambientais, primeiro nos próprios EUA e, depois, onde tais prerrogativas são postas à prova na perspectiva liberal do capital, como foram os casos de México (durante sua revolução que começou em 1910), Guatemala (1954), Brasil (1964), Chile (1973), Venezuela (2002) etc., notoriamente sabidos e agora comprovados com a revelação parcial dos documentos secretos das agências de inteligência norte-americanas com a confirmação do envolvimento de várias delas e seus cooperadores na derrocada de todos aqueles governos democraticamente eleitos.

No caso específico da ORIT/AIFLD que, decerto, foi onde tudo começou, quando em 1962 uma delegação da ORIT composta então pelo seu secretário geral Arturo Jauregui Hurtado, do senador mexicano Manuel Pavon e a célebre e polêmica figura do ex-representante interamericano da AFL-CIO e editor do boletim trabalhista interamericano, custeado pela ORIT, Sr. Serafino Romualdi ${ }^{84}$ (especialista em estudos latino-americanos) estiveram no Brasil para confabular a teoria democrática dos interesses capitalistas dos grandes conglomerados multinacionais usando de todos os subterfúgios imagináveis e possíveis. O congraçamento que se desenvolve entre diversas agências e

\footnotetext{
${ }^{84}$ Estudo interessante sobre este tipo de agentes especiais, está contido na obra "Desafio Americano à Preponderância Britânica no Brasil: 1808-1850" Capitulo III (pg 79 a 116) da Profa. Dra. A. Fernanda Pacca de Almeida Wright.
} 
órgãos através de pessoas constituídas para compor os conselhos, evidencia a existência de atributos comuns compartilhados pela elite industrial e trabalhista e os órgãos de inteligência.

Os atos encobertos na Guiana iniciaram-se no começo dos anos 50 quando Serafino Romualdi esteve auxiliando os serviços secretos Britânicos para reforçar as oposições sindicais subjugadas e favoráveis aos interesses propostos do capital hegemônico na derrocada de governos. No início dos anos 60 houve grandes greves na capital Georgetown e as operações cobertas foram intensas com o provimento de fundos aos partidos políticos de oposição. A AIFLD provia, como de praxe, cursos de treinamento e ajuda financeira e teve o apoio de outros sindicatos estadunidenses, dentre os quais, a entidade sindical pública: American Federation of State, County and Municipal Employees (AFSCME) ${ }^{85}$ que veio e tem vindo, justamente, caracterizar o congraçamento desta com os interesses hegemônicos representados por setores governamentais. $^{86}$

No caso do Haiti, em 1986, os "CEOs",87 das grandes corporações multinacionais estiveram muito preocupados com a direção dos movimentos trabalhistas haitianos e convocaram um "briefing" 88 intermediado pelo Departamento de Estado norte-americano em Washington D. C., com notórias intenções de intervenção, através da American International Free Labor Development (AIFLD) que já havia promovido e financiado a Fédération des Ouvriers Syndiqués (FOS) fundada no Haiti em 1984, como organização afiliada, que, como de praxe, tem sido sempre efetuada alhures onde tais instituições bem adestradas servem de pivô para a reformulação de conteúdo, de acordo com os valores propostos.

Um outro exemplo bem mais recente, também no Haiti, 13 dias antes do golpe de Estado, do dia 16 de fevereiro de 2004, uma delegação da ORIT/CIOSL e sindicalistas

\footnotetext{
${ }^{85}$ Rabe, Stephen. USA Intervention in British Guiana: A Cold War History. University of North Carolina. Chapel Hill, 2004, pág 40-65.

${ }^{86}$ As conexões do trabalhismo internacional nasceram em meados da Segunda Guerra Mundial, com a criação da agência de espionagem estadunidense Office of Strategic Services (OSS); a forte ligação deste serviço com a AFL (quando George Meany tornou-se seu diretor financeiro) e os movimentos trabalhistas internacionais foi estabelecida, a princípio, com o intuito de conter o avanço nazista e, depois, o avanço comunista, para finalmente, após a queda do muro de Berlim, alavancar os interesses hegemônicos dos grandes conglomerados capitalistas.

87 Pessoas com o maior posição hierárquica dentro das grandes corporações. "Chief Executive Officer" (CEO).

${ }^{88}$ Termo usado originalmente com o significado de instrução resumida para fins militares.
} 
do Suriname (ex-Guiana Francesa), França, Canadá e várias fundações internacionais estiveram participando de uma mesa redonda com membros da Coordination Syndicale Haitienne (CSH), esta acusada de conspiração pelo governo constitucional e democraticamente eleito do Haiti. Dados posteriores comprovaram o uso da violência e perseguição política contra vários sindicalistas, dentre os quais se destacaram os professores, estivadores, motoristas e empregados públicos que foram amplamente noticiados por várias organizações na defesa dos direitos humanos, inclusive pelo pósgraduando Jeb Sprangue, e o sociólogo, Prof. Dr. Kim Scipes, além de vários jornalistas, como a canadense Isabel MacDonald (Fevereiro/2006) em entrevistas. ${ }^{89}$

As próprias organizações trabalhistas envolvidas no esquema, tais como ORIT, Solidary Center (ex-AIFLD) e outras, quando perguntadas do por quê não denunciar estas violações, responderam com respostas evasivas, do tipo: "Fizemos várias declarações públicas" e "Não investigamos isto", como tem sido a praxe nestes casos específicos em que pessoas adestradas ou alienadas fornecem o conteúdo incólume do real objetivo. Um golpe de Estado como esse, causou mais de 8.000 mortes e cerca de 35.000 violações graves, como: extorsão, roubo e pilhagem. As greves eram convocadas pelos empregadores para criar o clima propício na defesa intransigente de seus interesses exclusivos como têm sido os vários casos em diversas localidades com interesses globais e que têm tido como resultado uma grande inquietação e angústia para o povo trabalhador.

A partição da imensa área geográfica da América Latina entre diversas etnias aliada à imposição de regras duras, pelos países colonizadores aos seus colonizados, em conseqüência da disputa por domínios, contribuiu sobremaneira para a desunião destes últimos, desde que facilitou o modo pelo qual os domínios dos interesses político/econômico manipularam de bom grado a incipiente classe política pela sublevação instilada por golpes de Estado.

Na execução de seus vários objetivos "democráticos", a ORIT chama a atenção para o condicionante implícito de aceitação da intensificação na formulação de centrais sindicais independentes, contrariando as premissas de central sindical única, esta sim

${ }^{89}$ Disponíveis no site: www.wakeupwithcoop.org que é uma mídia independente financiada por seus ouvintes, cidadãos ilustres e preocupados em desmistificar a grande farsa que se vive atualmente e que obscurece o intento de procurar a verdade, única forma, de libertar a todos desta amarra que está tornando a maioria das vidas insustentáveis. 
capaz de coesão na luta conjunta pela defesa coletiva de seus interesses tal qual a grande e única central trabalhista norte-americana denominada AFL-CIO que, mesmo com uma visão extremamente limitada nesta fase neoliberal e apesar dos esforços recentes, conseguiu trunfos relativos, embora não devidamente esclarecidos de forma estrita, para os trabalhadores norte-americanos. A união, em 1955, entre a American Federation of Labor e a Congress Industrial Organization (AFL-CIO) confirma a tese de que a dispersão não tem sido salutar para a defesa dos direitos dos trabalhadores. A ação inspirada no modelo apregoado pela grande central norte-americana, no entanto, parece contradizer algumas de suas ações mais significativas para os trabalhadores alhures. Sua proposta de reformulação do sistema capitalista parece bastante sensata, mas ignorar o conflito que existe entre as classes seria ignorar a própria existência destas, o que vem a mistificar a própria realidade a que se propõem investigar.

Espera-se somente que seu triste passado histórico tenha-se revertido numa atitude de bom senso para com a premissa fundamental dos direitos humanos, pois sua função original simples de promoção do sindicalismo ocidental em países tidos como sujeitos ao desgastado jargão de propaganda comunista, parece ter-se transferido para as funções originais da extinta $\operatorname{AIFLD}^{90}$ e o dissimulado Instituto Cultural do Trabalho (ICT), ou seja, fortalecer laços culturais, trabalhistas e sociais com um programa de assistência educacional, cursos diversos, incentivos ao Contrato Coletivo de Trabalho, seminários, cooperativas, mão-de-obra, encorajamento às organizações nãogovernamentais, movimentos sociais etc., com o intuito, dentre outros, de desalentar a malevolência implícita das multinacionais frente aos trabalhadores mais conscientes de seus direitos, em contrapartida aos interesses hegemônicos do capital.

Tais organismos internacionais mutantes, pela variável de inconstância sempre presente na sua equalização e com a falta de uma programação que se ajuste à verdadeira intencionalidade de reverter o quadro decadente deste modelo intervencionista, têm trazido à reflexão um modelo que seja mais condizente com os princípios de dignidade que se espera, no mínimo, estejam presentes no sujeito humano contemporâneo em suas

\footnotetext{
${ }^{90}$ American International Free Labor Development; no Brasil "Instituto Americano de Desenvolvimento do Sindicalismo Livre" (IADESIL). A partir de 1997 transmuda-se para o American Center for International Labor Solidarity (ACILS), mais conhecido como Solidarity Center/AFL-CIO, sob a liderança de John Sweeney com propostas de refazer o triste passado histórico com uma possível e alentadora proposta de abertura dos arquivos confidenciais de seus antecessores. Somente a retórica de solidariedade é condição necessária, mas não suficiente para mudanças de conteúdo.
} 
relações de trabalho como forma de ascender ao ideal dos direitos universais do trabalho. ${ }^{91}$

O alheamento do trabalhador norte-americano faz parte de uma estratégia global cujo ideal verdadeiro de democracia que habita o espírito da maioria daqueles trabalhadores é dissimulado pelos interesses hegemônicos do capital. A frustração por que passam vários líderes verdadeiramente democráticos é desalentadora com o cinismo que impera em certas organizações trabalhistas internacionais na defesa intolerante e exclusiva das prerrogativas capitalistas.

\footnotetext{
91“Ninguém se torna explicitamente aquilo que não é implicitamente" com esta afirmação feita pelo maior filósofo contemporâneo brasileiro, professor Huberto Roden, criador da filosofia universalista, deveria servir de base para a conscientização de como a globalização social poderia vir a ser o instrumento adequado para a sobrelevação humana na luta global da ainda incipiente e utópica "Cosmocracia" idealizada segundo parâmetros da filosofia universalista.
} 


\subsubsection{Balanço e retrospectiva histórica}

Um conciso retrospecto histórico de como interagem o governo, os negócios e a sociedade norte-americana faz-se necessário para um melhor entendimento do assunto.

A guerra de independência americana (1775/1783), da qual originou-se sua Constituição, foi essencialmente econômica, desde que teve a incumbência de livrar-se das altas tarifas das políticas mercantis inglesas e ratificar a posse das propriedades em termos de benefícios individuais. Verifica-se que as 13 colônias norte americanas já traziam, no âmago de suas expectativas, uma ascendência primordial favorável ao livre comércio, como prioridade exclusiva. A primeira emenda ${ }^{92}$ à Constituição, assinada em 17 de setembro de 1787, salvaguarda o direito à liberdade de expressão, de organização e a maneira pela qual se poderia exercer pressão ao governo na intercessão dos seus direitos. As primeiras dez emendas (Bill of Rights), conhecidas como "Declaração de Direitos”, proveram proteção para os indivíduos e corporações.

Após a guerra de Secessão ${ }^{93}$ (1861/1865), entre o governo federal e os estados do sul, os negócios dos grandes conglomerados capitalistas iniciaram um processo hegemônico em que dominariam os governos estaduais e o federal como nunca antes visto. Com o crescimento do Partido Republicano, as grandes corporações americanas tiveram papel preponderante nas arregimentações eleitoreiras dos presidentes alinhados com as premissas pró-negócios, desde os presidentes generais Ulysses S. Grant, em 1868, a William McKinley, em 1900. Ao mesmo tempo, houve grandes corrupções, com suborno no Congresso, derivadas da perspectiva de grandes lucros nos negócios pelas empresas.

Após o governo de McKinley, da reforma política da chamada "era progressista", aconteceram reações às celébres corrupções do sistema político dominado pelos grandes negócios. O "New Deal” de Roosevelt, em 1932, sofreu bastante com as ofensivas das corporações, que fez com que surgisse a decisão política de que o governo

\footnotetext{
92 "Congress shall make no law respecting an establishment of religion, or prohibiting the free exercise thereof; or abridging the freedom of speech, or of the press, or the right of the people peaceably to assemble, and to petition the Government for a redress of grievances".

${ }^{93}$ Com 618.222 mortes, foi a maior mortandade da história norte-americana, 52\% maior que a da Segunda Guerra Mundial que perfez 405.399 mortes. Jaz incôndito nestes números o ideário pelo qual uma sociedade tem estado subjugada aos seus valores!
} 
deveria controlar a economia de maneira mais efetiva para que esta não ficasse à mercê das descontroladas forças de mercado, delineando-se, assim, as premissas do keynesianismo. Keynes desenvolveu sua teoria com base num modelo especulativofinanceiro em que se destacava o "multiplicador de demanda" dos gastos governamentais e privados, como importante fator agregador do desenvolvimento econômico em termos de renda e emprego; entretanto, foi criticado por Schumpeter ${ }^{94}$ pela inferência de modelos abstratos lineares que não permitiriam uma interação adequada das variáveis consideradas para a dinâmica do processo. $\mathrm{O}$ que Schumpeter observara foi que a distribuição de fatores de produção de uma sociedade num determinado período é menos importante que o desenvolvimento empreendido em longo prazo, principalmente quando relacionado ao aprimoramento tecnológico inovador.

O período de cronologia imprecisa, em tela, caracterizara-se pelo início das pesquisas fundamentais desenvolvidas pelas universidades norte-americanas em relação mais direta com os interesses corporativos que partem do pressuposto schumpeteriano de que o poder do capitalismo advém do lucro auferido com a utilização da criatividade, donde proveio a famosa asseveração soberba do processo evolucionário do capitalismo: “destruição criativa”, cuja estabilidade de mercado é entremeada por choques ou descontinuidades que dilapidam o velho processo de vantagens, pelo novo; sendo que é a competição que norteia a inovação, e todos os novos espíritos empreendedores (Unternehmergeist) obtêm uma acumulação de capital excedente, o que permite às corporações desenvolverem produtos superiores em termos tecnológicos e capacidade organizacional. Ou, em outras palavras, a competição que existe entre as corporações produtoras de know how no desenvolvimento de produtos agregados de novas tecnologias e de aprimoramentos na capacidade organizacional, são mais valiosos do que aqueles preceituados pela "teoria de equilíbrio" de tradição neoclássica, sendo a variação destes últimos relativa ao preço e ao comportamento de mercado.

Desde o paradoxo, que Adam Smith observara, de que o desenvolvimento monopolista não era salutar para a eficiência econômica à afirmação de Schumpeter de

\footnotetext{
${ }^{94}$ Economista e sociólogo (1883-1950), nascido em Trest (Morávia), antiga Tchecoslováquia, professor de economia e teorista social na Universidade de Harvard a partir de 1932 até o fim de sua vida. Vivenciou as duas grandes guerras mundiais que permitiram o desenvolvimento de altas tecnologias. Foi contemporâneo de John Maynard Keynes (1883-1946) e também da crise capitalista de 1929, Joseph Alois Schumpeter, com 18 anos de atividades acadêmicas nos EUA, desenvolveu teoria muito interessante da evolução do capitalismo.
} 
que o monopólio temporário através da "destruição criativa" tem sido ferramenta essencial no desenvolvimento econômico em longo prazo; conclui-se de que tem sido muito eficaz para afiançar as idéias neoliberais deterministas da nova economia, onde o esforço criativo é a mola mestra que conduz a forma pela qual a moderna acumulação de capitais oligopólicos se avulta no desenvolvimento de uma amplitude de novas tecnologias, sem a inferência primordial das variáveis "fator humano e ambiental" nas suas premissas. Isto é realmente uma criação exemplar de como idéias originais derivamse por "caminhos nunca dantes percorridos" quando se afirma que a relevância de um sistema de mercado capitalista consiste na oportunidade de recompensa que este sistema mutacional poderia prover àqueles que inovam e, destarte, tiram proveitos monopolistas da inovação.

John Maynard Keynes (1883-1946), John Kenneth Galbraith (1908-2006) e outros economistas daquela geração tiveram um olhar preocupante quanto ao monopólio privado, conquanto Galbraith admitisse o monopólio público, desde que voltado essencialmente para atender demandas essenciais da comunidade, tal preocupação relutante não se explicita nas considerações de Schumpeter, denotando mais um caráter de sucesso econômico privado, ainda que nos alertasse para o fim do capitalismo pelas suas próprias contradições (a exemplo de Marx, as contradições do capitalismo tornam-se exacerbadas no momento que precede o seu próprio esfacelamento, pela revolução do proletariado é instaurado o comunismo; mas, para Schumpeter, o fim do capitalismo darse-ia pela inovação tecnológica, ou seja, a "criação destrutiva"), mas as conseqüências, em longo prazo, para os valores sociais mais abrangentes, parecem não ter conotação de essencialidade primordial de equilíbrio e sustentação que as modernas teorias julgam procedentes como forma de assegurar o primado de nossa existência.

A "mão invisível” de Smith ou a "criação destrutiva" de Schumpeter? Que a ciência econômica deve-se adaptar à natureza da economia? Qual é a natureza da economia? Destes questionamentos pode-se extrair, a título de conclusão, o seguinte proveito: as novas teorias não invalidam totalmente as velhas teorias, há que se equilibrálas com boas políticas que atribuam ao Estado o seu papel regulador e incentivador de melhorias contínuas de crescimento econômico, com infra-estrutura adequada para intensificar e diversificar as idéias dos agentes inovadores que tenham, por objetivo, a cooperação entre indivíduos num ambiente de harmonia e compreensão. 
Karl Polanyi em seu livro A grande transformação, de 1944, mostrou-se adversário das teorias econômicas liberais e deterministas quando propôs que os sistemas econômicos estão intimamente inter-relacionados ao contexto social, político, cultural e institucional. Segundo sua tese, a idéia de mercado regulador é inadmissível "sem destruir a essência natural e humana da sociedade, transformando-a em uma selvageria". 95 Polanyi demonstrou que os mercados são construções sociais, formuladas pelos Estados através de políticas econômicas desenvolvimentistas, que dependem do contexto em que se inserem. Estas políticas produzem mudanças nas economias tradicionais, de modo a exaltar os interesses econômicos de mercado, confundindo a inerente qüididade humana com mercadoria que a cediça teoria econômica liberal propusera nos idos do século XIX.

A advertência que nos faz do economicismo prevalecente remete-nos à urgência de contribuirmos de maneira mais enfática nas economias solidárias das quais o social tem papel preponderante na edificação da economia como forma de sobrelevar a categoria humana, supondo-a capaz de construir uma nova sociedade, com a aptidão de vencer a árdua luta pela sobrevivência, não pela falta de recursos da mente economicista, mas pela percepção consciente de que o mercado tem a necessidade de controle social e o fator econômico deveria coadjuvar o social e não estabelecer com este um relacionamento conflituoso. Nesta lógica de mercado, não poderia haver o erro fundamental de se fazer prevalecer a premissa menor no lugar da maior, como forma de dar sustentabilidade ao sistema, cuja insofismável inexorabilidade torna-se mais evidente no dia a dia. Não existe a opção de escolha, no que resulta da implementação de uma política arbitrária que, entretanto, não é inevitável; falta-nos, outrossim, um instrumento adequado que nos permita exercer a plena cidadania, conforme os aspectos primordiais de nossa identidade.

A nova economia norte-americana exprime um descompasso em relação ao rigor de um mercado perfeito, pois, como se sabe sempre foram imperfeitas as situações reais de concorrência. A nova economia neoliberal global é cada vez mais competitiva e centralizada, mas não em termos da produção clássica, mas da "destruição criativa", como foi designada por Schumpeter. O equilíbrio que deveria ser levado em conta, nesta altura dos acontecimentos, parece irremediavelmente perdido, trazendo à tona a caótica situação do homo oeconomicus dividido entre a sobrevivência e sustentabilidade. Na verdade de que tudo é relativo, evidencia-se a sobredeterminação; ou seja, de que esta também é

\footnotetext{
${ }^{95}$ POLANYI, Karl. The Great Transformation: The Political and Economic Origins of Our Time. Boston: Beacon Press, 1944, pág. 78.
} 
relativa: o paradoxo epistemológico legitima perfeitamente a defesa de valores estáveis extra-econômicos que no fim das contas, correspondem àqueles valores que também devem orientar uma ética na política que não seja vazia.

Os 26 anos dourados da economia norte-americana, entre 1946/1972, foram agraciados com uma dinâmica própria de um capitalismo crescente com concessões privilegiadas. Os trabalhadores de então, de combatividade exemplar, tiveram muitas de suas reivindicações atendidas sem maiores delongas. A expansão do comércio influencia o crescimento da economia, proporciona o aumento salarial e a criação de empregos, de acordo com a lei da oferta e procura. O estilo americano de viver foi resultado da combinação destes fatores keynesianos de bem-estar na economia.

Durante os anos sessenta aos setenta, a política americana foi enaltecida pelas perspectivas de reforma liberal, mas, ao mesmo tempo, surgiram grupos antagônicos às políticas corporativas, com ênfase nos direitos humanos, meio ambiente e direitos dos consumidores, mudando, em definitivo, as perspectivas imperturbadas dos grandes negócios corporativos globais.

A tendência que hoje existe de crescimento no uso, não tradicional nos EUA, dos tribunais de justiça na resolução de disputas trabalhistas (labor courts) está diretamente ligada ao aumento de competitividade que os grandes blocos econômicos travam entre si através de seus processos produtivos transnacionalizados que tem ocasionado a corrosão do padrão nacional de direitos trabalhistas representado pelo contrato coletivo, mais a exportação de empregos para outras áreas de mão-de-obra a custos mais baixos. Se considerarmos a disponibilidade estrutural de mão-de-obra de reserva disponível no mundo, dentro da lógica de comércio livre apregoada pela AFLCIO através de seus institutos, como foi a AIFLD e a atual "Solidarity Centers", podemos esperar que a situação dos trabalhadores norte-americanos tenda a se precarizar ainda mais por diversas razões, entre elas:

- $\quad$ Existem 6.000 associações comerciais com forte poder de barganha;

- $\quad$ Existem 700 corporações com forte lóbis e boa recepção no Congresso;

- Os lóbis são vagamente regulamentados e deles vem a principal fonte de recursos eleitorais;

- $\quad$ A conseqüente formação de CAPs (Comitês de Ação Política) pelas grandes corporações e sua elite serviçal; 
- $\quad$ apesar de todos os esforços de tentar moralizar a influência corporativa nas eleições, tal intento ainda não se concretizou de maneira categórica, reafirmando, veladamente, a autocracia corporativa transnacionalizada.

Quanto ao panorama da política externa, tanto o partido republicano como o partido democrático, historicamente, têm comparticipado do mesmo ponto de vista, diferindo apenas na forma, mas de mesmo conteúdo. Quanto à política interna, são discordes no que concerne à formulação correta de políticas públicas de bem-estar social, que a fraca oposição em ambos partidos, representada pela esquerda sindical e a direita evangélica, não conseguem solucionar.

No caso do Brasil, com todas as resultantes do processo de dívida externa crescente, crise internacional, PIB per capita declinante, políticas econômicas recessivas impostas pelos credores, corrupção, aumento da informalidade e falta de execução de um planejamento genuinamente nacional, o resultado tem sido indeterminações de conteúdo. 


\subsection{Experiência sindical na "Nova República" (1985-2005)}

A incrementação da política neoliberal no começo da década de 90 trouxe como conseqüência um maior teor de insustentabilidade para o sistema econômico de formato subsidiário, haja vista a indústria nacional afetada negativamente no seu perfil industrial com a quebra de muitas indústrias, mormente aquelas de uso tecnológico mais intensivo, aumento das importações de partes eletrônicas e um maior desenvolvimento das firmas que atendem o mercado externo quanto ao suprimento de matérias-primas essenciais ao processo produtivo global. As privatizações das entidades públicas, parcerias ou fusões públicas-privadas, acessibilidade irrestrita ao comércio e eliminação das regras governamentais para o mercado financeiro acarretaram dificuldades para uma ação coletiva em defesa dos direitos sociais e trabalhistas já consagrados. Foram as conseqüências desta política econômica não adequada à sustentabilidade do sistema que influíram desfavoravelmente, com a indefinição das relações trabalhistas, maior persistência na institucionalização do Contrato Coletivo de Trabalho, cooperativas de mão-de-obra, terceirização, contratos parciais, contratos por tempo determinado e outros instrumentos flexibilizantes, cujas seqüelas têm sido o desemprego, a falta de criação de emprego e, por conseguinte, o aumento da informalidade.

O surgimento das centrais sindicais pulveriza, ainda mais, a heterogênea classe trabalhista brasileira com o enfrentamento e luta pelo poder nos sindicatos de base. $\mathrm{O}$ descontentamento destes torna-se generalizado com a interferência das centrais nas suas autênticas atribuições de representação. Marcou época na história do sindicalismo brasileiro a fundação, em 1983, da Central Única de Trabalhadores (CUT) que, ligada, ao Partido dos Trabalhadores (PT), transformou-se em ferramenta poderosa de negociação. Surgiram, no mesmo período, as Confederações Gerais de Trabalhadores (CGTs) com políticas adversas, o que culminou com a formação, em 1991, da Força Sindical de expressiva representação dos trabalhadores.

Entretanto, são poucos os sindicatos que atendem aos verdadeiros interesses dos trabalhadores, pois estão mais interessados em tirar proveitos próprios valendo-se da própria legislação trabalhista. 
O conceito de industrialização secundária conota uma situação de subalternidade, pois o "Welfare State", ou seja, o estado cujo governo proporciona o bemestar de seus cidadãos através de leis sociais, não se consolida em termos reais e começam a prevalecer interesses neoliberais mais incisivos, cujas ações mercantis garantem privilégios dentro da superestrutura política global. Generalizar a negociação coletiva de um contrato de trabalho numa economia extremamente submissa seria atrelar a própria dependência aos resultados econômicos conjunturais da economia nacional, exceto por poucos sindicatos de trabalhadores, com forte preponderância dos sindicalistas metalúrgicos, nas indústrias mais dinâmicas dos conglomerados transnacionais com interesses globais, que puderam usufruir aumentos reais de salário no final do século passado e início deste. Apesar de haverem conseguido algumas vitórias, tiveram que se sujeitar à flexibilização na jornada de trabalho através do banco de horas, à inferência da participação no lucro das empresas no molde do modelo alemão, de acordo com a medida provisória 794 de 1994, que corroborou com a descaracterização da luta sindical própria na negociação dos valores acordados entre a Indústria e os trabalhadores, de maneira mais direta. A organização e gestão de representação do trabalhador no chão de fábrica "OLT" (organização no local de trabalho) também se tornou uma luta preferencial.

O pragmatismo que tinha caracterizado os sindicatos mais fortes mudou sua linha de luta combativa para um sindicalismo mais aliável, ajustando-se à nova conjuntura econômica global e desfazendo toda uma perspectiva de luta conjunta de interesse coletivo, amoldando-se mais ao estilo do sindicalismo por objetivos que tem caracterizado o modelo norte-americano. Um indicador de tal perspectiva, digno de nota, foi a diversidade na forma das greves nas indústrias que obtiveram resultados coincidentes, em contrapartida às greves de confronto mais abrangentes. Sempre que se vislumbram, no cenário político, mudanças significativas de poder, mais atentos ainda ficam os construtores de impérios comandados pelos interesses hegemônicos do capital, cujo domínio de tendência açambarcadora dos meios de comunicação torna-se essencial aos seus objetivos. Observou-se que, de 1977 até 1985, os sindicatos mais vigorosos foram, também, os alvos mais intensos de programas de disseminação de idéias e informações, nem sempre patenteadas, com o uso de modernas técnicas de comunicação dirigida, inclusive as psicológicas de condicionamento e comportamento promovidas pelos diversos órgãos e agências de inteligência submissas ao ideário neoliberal global dos 
governos de países com maiores interesses locais. Um exemplo clássico disso foi o caso dos sindicatos dos trabalhadores japoneses que, insurgindo-se após a Segunda Guerra Mundial de maneira mais taxativa, foram desbaratados pelo empresariado que os compelira ao sindicalismo por empresas.

As lutas férreas que foram características daqueles sindicatos tornaram-se mais fracionadas na medida que, dentro de uma mesma classe profissional, começava a prevalecer as negociações do contrato de trabalho por empresas, desfazendo-se o princípio tradicional de maior união classista como forma de luta mais acorde com os interesses coletivos.

Foi a partir do governo do presidente Itamar Franco, em 1994, cujo ministro da Fazenda à época era Fernando Henrique Cardoso, que se colocara em prática um plano antiinflacionário de controle monetário, desindexação e estabilidade cambial (Plano Real), em que os reajustes salariais passaram a ser negociados livremente entre os interessados, sem a ingerência do governo; diga-se de passagem, não havia sido instituída para a defesa dos trabalhadores na luta desigual sempre favorecedora dos interesses capitalistas, conforme o princípio fundamental do Direito de Trabalho, de hipossuficiência do trabalhador. Os reflexos deste plano, no mercado formal de trabalho, foram o crescimento da destruição de empregos e diminuição da criação dos mesmos. Se compararmos com os dados da década de 1980, foram destruídos 1,4 milhão de empregos na indústria de transformação, e 400 mil nos estabelecimentos de crédito. ${ }^{96}$

Esta característica de menor ingerência do governo na economia é fruto da política neoliberal comandada pelos grandes interesses econômicos/financeiros das empresas transnacionais que visam auferir maiores lucros no conturbado mundo globalizado, pois o modelo importado fordista dá sinais de arrefecimento com a queda de produtividade do trabalho atrelada à estrutura acumulativa do capital. $\mathrm{O}$ enfraquecimento do poder normativo na regulamentação da relação entre o capital e o trabalho está diretamente relacionado ao aumento do poder das transnacionais que, de maneira nem sempre direta, mas coercitivamente, ditam os rumos que as economias dependentes devem trilhar, pois todos os óbices que pudessem dificultar-lhes os intentos deveriam ser, sumariamente, minimizados ou descaracterizados, quando não subtraídos.

\footnotetext{
${ }^{96}$ DEDDECA, Claudio Salvadori. Produtividade, emprego e salário na indústria brasileira. In: Anais do XXVII Encontro de Economia - ANPEC. Belém, 1999, pp. 2043-2058.
} 
A lógica prevalecente tem sido o preceito neoliberal de acirrada competição em que as empresas e trabalhadores menos organizados e conscientes são os mais afetados. Está explícita na declaração de princípios dos Institutos Liberais, a qual estabeleceu de maneira mais categórica neste período (1986), toda a formulação estratégica a que as políticas públicas deveriam se submeter para a efetivação ideológica de seus preceitos, em particular, nos estados com maior poder político/econômico:

- flexibilização total da relação capital x trabalho ao sabor do alegado livre jogo de mercado;

- colocar sob controle de empresas particulares a gestão da previdência, educação e saúde.

O retrocesso que se verifica nestas áreas é evidente pelo que se infere, da ideologia que o mascara e determina, também, políticas econômicas recessivas que suscitam o desemprego e, conseqüentemente, o enfraquecimento dos sindicatos de trabalhadores, mormente os menos expressivos, de acordo com o discurso liberal. As contradições tão evidentes do jargão "livre comércio" como salutar para o crescimento econômico se evidenciam nos próprios fatos econômicos e quem deles se avantaja. Nas décadas de 1960 e 1970, apesar de uma maior proteção ao livre comércio, a dinâmica da economia mundial foi bastante superior que a das décadas de 1980 e 1990, em termos do aumento da renda per capita que teve um crescimento superior a $1 \%$. O preço que se paga pelo avanço desenfreado do capitalismo é o desalento face à precarização generalizada dos serviços essenciais da sociedade e a distribuição mais desequilibrada da renda daquela que habitualmente se verificava.

Pesquisa feita pelo IBGE, de 1991 a 1998, demonstra uma quase perfeita interdependência entre duas variáveis, ou seja, a participação do trabalhador sem contrato ou carteira de trabalho assinada $(\mathrm{a}+)$ é equivalente à daqueles que se aventuram no trabalho por conta própria $(+b)$ com a abertura de pequenas empresas; entretanto, a grande quantidade de pequenas empresas que são fechadas (muito intensamente neste período) sinaliza, como de fato se deu, o aumento na informalidade $(=\mathrm{c})$ que, na equação acima, congrega a resultante das duas variáveis, ou seja, o contrato de trabalho precário que facilita, ainda mais, a já bastante acessível dispensa involuntária, sendo que a conjuntura econômica desfavorável aumenta o número de falências ou concordatas. 
A harmonização entre empresas e empregados, sem interferências indevidas, é o que realmente favorece a sustentabilidade de ambas instituições com respeito mútuo às suas determinações de auto-suficiência econômica.

A promulgação da Constituição de 1988 demonstra o despreparo dos legisladores no tocante a este problema, mais preocupados com o desfecho da ditadura militar do que com uma reformulação para um efetivo fortalecimento das relações de trabalho que pudesse atender à grande maioria de trabalhadores com representação precária ou mesmo sem representação, pois pontos cruciais para a sua evolução, apesar de haverem sido vislumbrados e questionados, não foram solucionados: a unicidade sindical e o imposto sindical que foram outrora instrumentos importantes, mas foram transformados em meros instrumentos de "politicagem" sindical, tornando patenteados o descrédito e a desagregação da classe trabalhadora.

\section{CRESCIMENTO DO PIB - BRASIL}

\begin{tabular}{|c|c|c|}
\hline PERÍODO & $\underline{\text { PIB }}$ & $\underline{\text { PIB/HABITANTE }}$ \\
\hline $1971 / 1980$ & & $\mathbf{5 . 7 0 \%}$ \\
\hline $1981 / 1990$ & $\mathbf{8 . 6 0 \%}$ & $\mathbf{- 0 . 3 6 \%}$ \\
\hline $1991 / 2000$ & $\mathbf{1 . 5 5 \%}$ & $\mathbf{1 . 1 3 \%}$ \\
\hline
\end{tabular}

Fonte: IPEA. 
CRESCIMENTO DO PIB - MÉDIA ANUAL

$1950 / 2000$

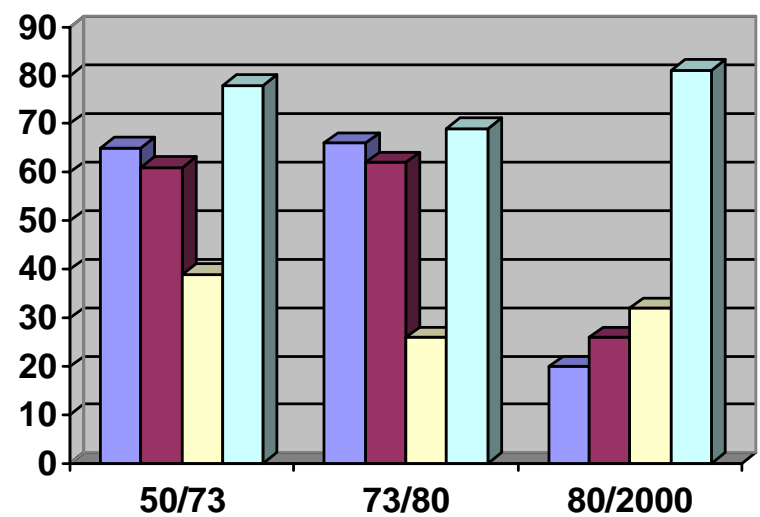

\begin{tabular}{|l|}
\hline Brasil \\
$\square$ México \\
$\square$ USA \\
$\square$ Coreia Sul \\
\hline
\end{tabular}

Fonte: Groningen Growth and Development Centre. Groningen University, Holanda.

\section{PRODUTO NACIONAL BRUTO Per Capita}

US\$ (000)

\begin{tabular}{|c|c|c|c|c|c|c|}
\hline & 1.998 & 1.999 & 2.000 & 2.001 & 2.002 & 2.003 \\
\hline Brasil & 4610 & 3900 & 3670 & 3110 & 2860 & 2710 \\
\hline Estados Unidos & 30700 & 32250 & 34360 & 34650 & 35400 & 37610 \\
\hline México & 4020 & 4460 & 5110 & 5560 & 5940 & 6230 \\
\hline Coréia do Sul & 8500 & 9220 & 9790 & 10580 & 11280 & 12020 \\
\hline
\end{tabular}

Fonte: Banco Mundial. The World Bank Atlas (vários anos) 


\section{PNB per capita}

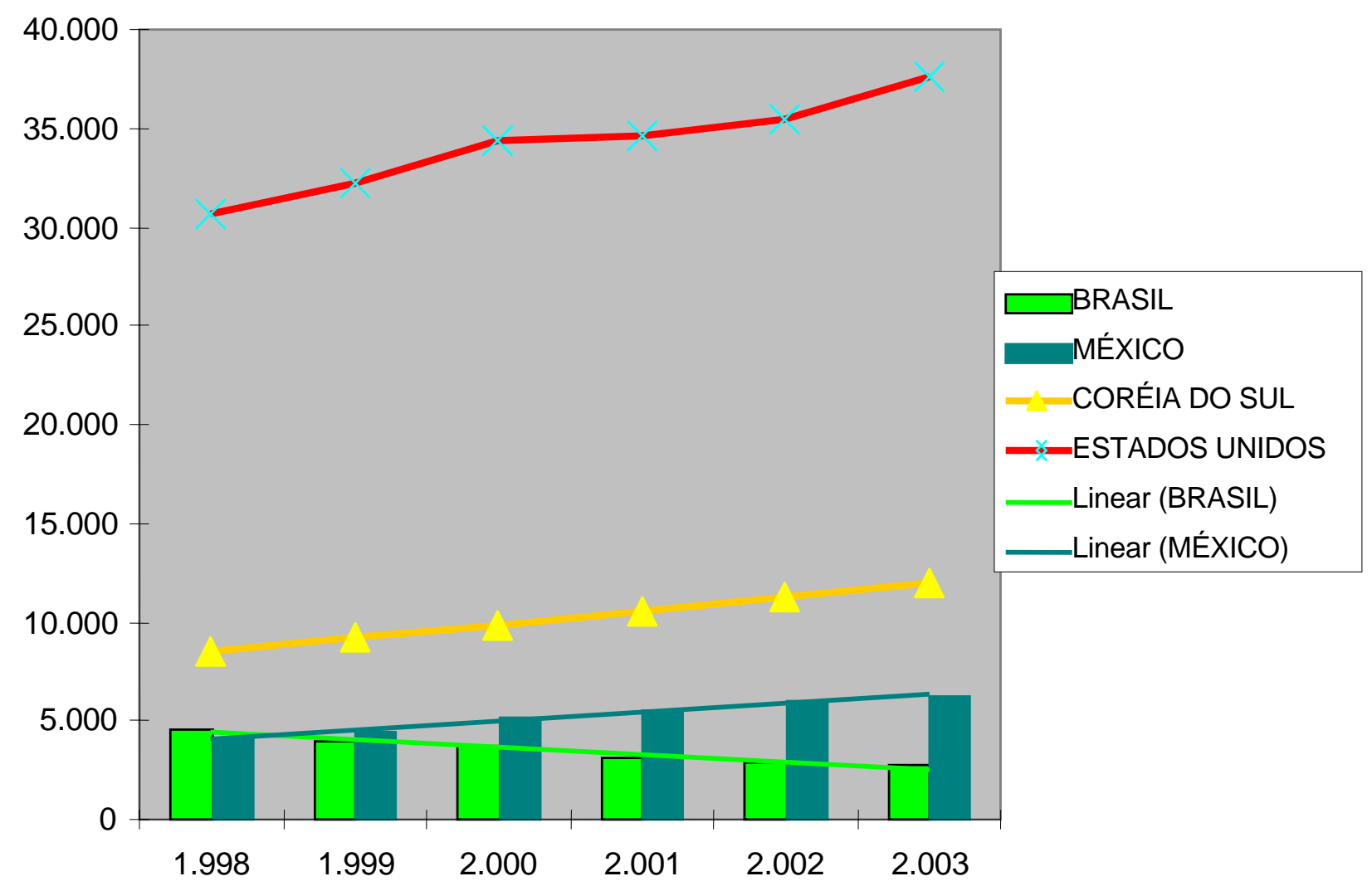

Fonte: Banco Mundial. The World Bank Atlas (vários anos)

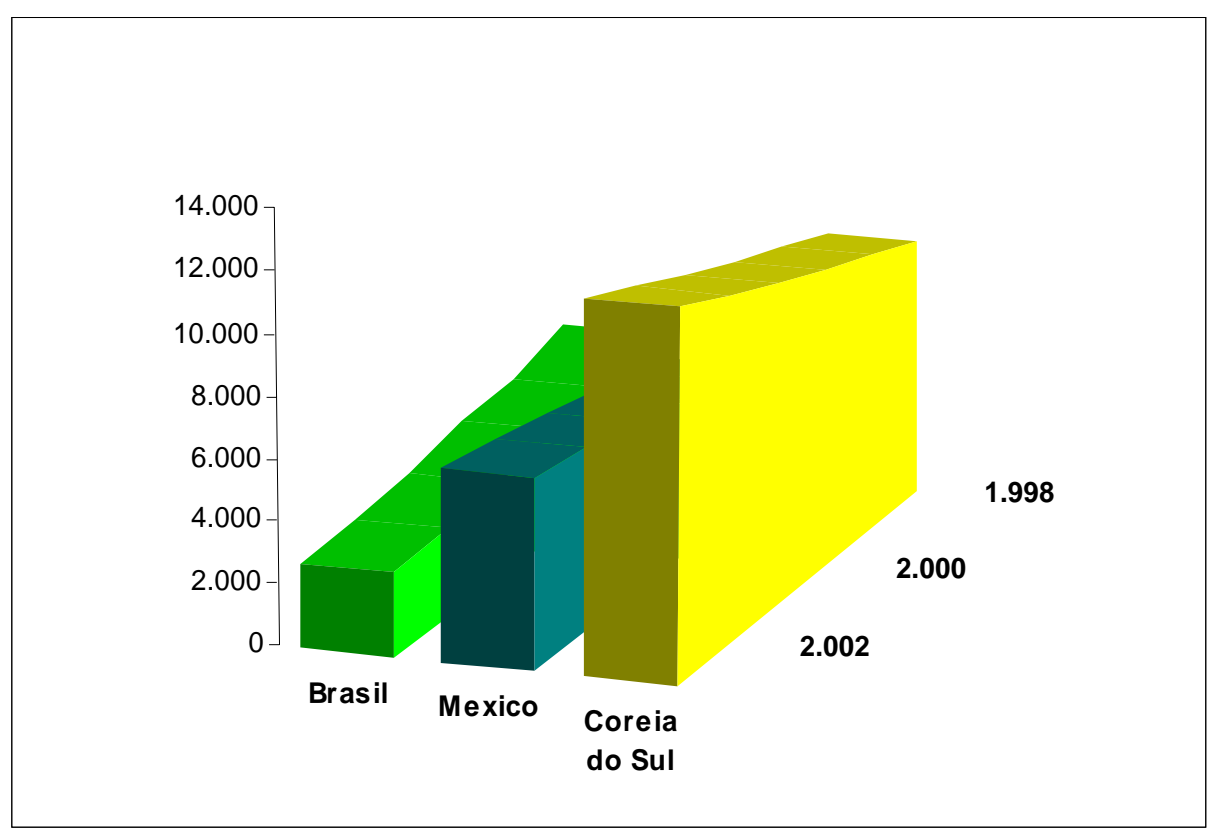

Fonte: Banco Mundial. The World Bank Atlas (vários anos) 
A comparação entre o PIB e PNB dos quatro países, conforme abordado na metodologia deste trabalho, torna-se esclarecedora quando invocamos as contas nacionais no seu conteúdo de rendas enviadas e rendas recebidas e vemos a coerência do sistema mundial e quem dele se prevalece por interesses capitalistas hegemônicos nesta década (1990-2000) de imposição da política neoliberal mais acirrada. O ponto de ruptura deu-se na denominada década perdida (1980-1990), em que a falta de maior autonomia consolidada se reflete na falta de autenticidade, em contraste à suposição de um desenvolvimento real em que o capital hegemônico pudesse beneficiar, de fato, a economia, dando-lhe uma maior sustentabilidade que é, na realidade, o que determina o fortalecimento e o real desenvolvimento da mesma. Este quadro de dependência tende a incrementar os sérios problemas sociais, determinado pelo enfraquecimento político, de parte significativa de elementos governamentais ardilosos, incompetentes e submissos. $\mathrm{O}$ que a teoria permitiria afirmar quanto ao asserto de subalternidade, de agora em diante, a comprovação histórica não permite questionar a significância em termos de compromisso e objetivo nacionais.

A vivência no conturbado mundo diplomático imbricado aos grandes interesses capitalistas permite que se estabeleça um forte elo entre os acontecimentos mais recentes com referência às determinações que podem influenciar a economia política dos países a elas subjugados. A eleição em 2002 do Exmo. Sr. presidente Luiz Inácio Lula da Silva causara certo desassossego no Congresso norte-americano, devido ao tradicional temor à ameaça "vermelha" que ainda está fortemente condicionada na mente da maioria daqueles parlamentares.

O processamento de considerável quantia de informações através de variados filtros e analisadas por " $n$ " agências especializadas chegou a um resultado nas mãos daqueles que são intitulados de usuários finais (end users), que neste específico caso, foi o especialista em finanças internacionais, o então presidente da "Federal Reserve" (FED), Sr. Alan Greenspan que, com muita discrição, anunciou aos ávidos e impacientes investidores que poderiam acautelar-se, pois o presidente eleito do Brasil poderia ser comparado com os aguerridos sindicalistas estadunidenses que se sobressaem pela sua veemência à negociação de seus contratos de trabalho. Em outras palavras, ele quis dizer que o aparente problema político não era consistente e que os rumos da economia poderiam prevalecer sem futuros constrangimentos à ordem pré-estabelecida. 
Se observarmos a tática dos serviços de inteligência nas diversas agências, verificamos que os mesmos elementos-chave, por meio de diferentes nomeações, estiveram presentes nos distritos consulares em épocas diferentes, mas todas elas de importância pelas conseqüências políticas que adviriam na possível mudança de paradigmas, a exemplo do que ocorreu com períodos pré-1964, "Nova República” e pósFHC.

Com a crescente sofisticação tecnológica dos meios de comunicação monopolizados nas mãos dos construtores de impérios, sobrelevou-se o condicionamento tácito a que a natureza do ser humano tem sido submetida para consolidar aqueles valores contrários à verdadeira solidariedade democrática e à construção de uma cultura de paz entre os povos trabalhadores.

Quanto mais necessitamos destes autênticos valores humanos de dignidade, mais se degrada o ambiente favorável à sua construção. A construção destes cenários, contrários ao bom senso no inconsciente coletivo, vem aviltando o mais autêntico destino dos trabalhadores na consecução de seus desígnios como seres humanos. É um projeto inconcluso, assim como a elaboração e desenvolvimento de um instrumento que nos possa dar a oportunidade de usufruir a harmonia universal para estarmos coesos com a realidade cósmica adjunta ao sujeito humano realizador.

Tudo leva a crer que para o ser humano cumprir o seu "destino" fazem-se necessárias condições condignas para um pleno desenvolvimento espiritual. $\mathrm{O}$ ideal seria que se trabalhasse menos e se tivesse mais tempo de ócio para ser preenchido por atividades desinteressadas e incondicionadas, no sentido de um exercício pleno da liberdade. Sem falar na possibilidade de se desenvolverem atividades múltiplas que resgatassem em uma existência "autêntica", o homem integral, em contraposição ao homem unidimensional de Herbert Marcuse (1898-1979).

Muitos sociólogos futurólogos da década de 1960 previam que no futuro, devido à automação principalmente, o ser humano estaria desincumbido de tarefas muitas vezes aviltantes que tomariam parte de seu precioso tempo. À época, nem cogitavam sobre a questão do desemprego e a exclusão do homem pela máquina, sendo que esta teria sido criada com a finalidade única e exclusiva de lhe proporcionar conforto.

Assim como a ciência, de uma maneira geral, era vista naqueles eufóricos e ingênuos tempos como uma aliada poderosa, fruto da inteligência humana voltada para a 
salvaguarda da espécie e o cumprimento do seu destino. Outrossim, não se pode ignorar o caráter exploratório e destruidor a que as descobertas científicas foram e continuam sendo submetidas, muito embora estas, em si mesmas, não sejam nem boas e nem más, mas tãosomente o uso que se faz delas. 


\section{O N C L U S Ã O}

A perversidade da história alienante que, em vez de conscientizar as verdadeiras razões pelas quais uma população não consegue tomar consciência da realidade que a envolve, debilitando a possibilidade de lutar para seu próprio progresso, está envolta por condicionantes advindos, principalmente, de uma educação iníqua cujo efeito desorientador favorece aos interesses mal-intencionados e cuja retórica hodierna tem sido palco de espetáculos estarrecedores na subjugação que nos tem sido imposta desde tempos imemoráveis.

A nova ordem mundial pressupõe a articulação de políticas econômicas subjugadas a um modelo ambíguo de economia política onde sobressai o descomprometimento do Estado nas suas atribuições clássicas segundo o receituário neoliberal, entretanto, tal fato não se verifica no eixo Norte-Norte onde cada caso é delineado de acordo somente com os grandes interesses econômicos envolvidos.

Ainda que as leis básicas do trabalho nos Estados Unidos, México e Brasil proclamem a proteção dos direitos aos trabalhadores de organizarem-se, os procedimentos seguidos por estes países são diferentes. No Brasil e México, os sindicatos com o respaldo de matriz constitucional, dependem ainda do registro no órgão competente para a sua efetivação. Nos Estados Unidos é a eleição dos trabalhadores por voto secreto, conforme os procedimentos específicos na Seção 9 da NLRA e nos regulamentos publicados pela NLRB, que garante ou nega a representação dos trabalhadores com poderes para negociar coletivamente, ou seja, independente de registro prévio, pois o governo apenas tenta organizar a efetivação voluntária dos trabalhadores.

Diferenças quanto à formação dos sindicatos:

\begin{tabular}{|l|c|c|c|}
\hline & BRASIL & EUA. & MÉXICO \\
\hline \multicolumn{1}{|c|}{ FILIAÇÃO } & obrigatória & voluntária & voluntária \\
\hline INSTITUCIONALIZAÇÃO DOS DIREITOS & constitucional & não constitucional & constitucional \\
\hline RECONHECIMENTO DO PODER PÚBLICO & necessário & não necessário & necessário \\
\hline CARACTERISTICAS FORMAIS DA ENTIDADE & restritas & amplas & restritas \\
\hline REPRESENTAÇÃO & unicidade & pluralismo & pluralismo \\
\hline CONDIÇÃO CONTRATUAL & legislação & negociação & legislação \\
\hline
\end{tabular}




\begin{tabular}{|l|c|c|c|}
\hline FUNÇAO DO ESTADO & ampla & mínima & ampla \\
\hline PREVIDENCIA SOCIAL & integrada & separada & integrada \\
\hline
\end{tabular}

Certos aspectos quanto à formação tradicional dos sindicatos no Brasil e México estão transformando-se, pois, nos EUA, a condição de fato depende das partes na negociação do contrato de trabalho e não tanto da lei ou da natureza das coisas. No México, a filiação é voluntária, mas quem não estiver afiliado ao sindicato não tem o direito de indenização, o que na prática deixa o empregado sem uma opção, determinando, de fato, sua obrigatoriedade.

Outro destaque seria um modelo que encetasse os trabalhadores não a uma cultura de confronto que hoje domina as relações de trabalho, mas a um modelo que cultuasse a cooperação, pois, contrariamente à cultura de negociação bastante aprimorada que predomina nas negociações norte-americanas, não existiu um desenvolvimento mais peculiar desta mesma cultura no Brasil e México.

A Suécia, por exemplo, a partir de 1930, aprimorou a cultura de negociação e tem hoje uma das melhores distribuições de renda do mundo e, destarte, negociações coletivas exemplares de respeito aos direitos dos trabalhadores e consciência empresarial que são modelos adequados ao desenvolvimento alcançado pelos povos bálticos.

Restrições às iniciativas autênticas e próprias de desenvolvimento econômico, historicamente sempre se sucederam, mas precisamos defrontá-las com atitudes próativas, e não somente com uma reação às contingências ditadas por interesses que não os próprios e autênticos de um povo não subjugado pelo legado colonial em que a elite liberal centrou-se para a formulação de políticas econômicas de bens complementares aos da metrópole. Esta visão estruturalista da dependência acentua-se na intensificação da concorrência no mundo global emanado dos centros de poder imperial que monopolizam estas relações, criando um elo de compatibilidade inadequado para um crescimento econômico mais autêntico que pudesse dar melhor condição de sustentabilidade ao modelo.

A economia do México baseia-se na singularidade de três elementos: o governo, que tem o monopólio do rentável ramo de petróleo; as empresas estrangeiras, basicamente as norte-americanas e coreanas que exploram a mão-de-obra barata através das "maquilas"; e os subjugados capitalistas mexicanos denominados "tyccons". Nesse contexto, não somente as relações coletivas de trabalho, mas também as relações sociais, 
tendem à precarização. Nesta época da globalização de fundamentos neoliberais, o capital e o trabalho imersos em uma realidade de constantes mudanças encontram dificuldades na adequação das normas legais às suas necessidades. A demora de um processo amplo de modificação na dinâmica das leis não acompanha a celeridade das mudanças econômicas e só beneficia a outra parte que, sem dúvida alguma, estaria mais ágil e coerente com o atual estádio da evolução capitalista e, por conseguinte, mais apta a receber os frutos que deveriam beneficiar de maneira mais justa a sociedade trabalhadora. Os trabalhadores brasileiros, mexicanos e norte-americanos e seus respectivos sindicatos têm tido importância fundamental na história dos seus países, tendo seus movimentos determinado o papel que o desenvolvimento histórico específico teve para cada um, variando em intensidade e grau, de acordo com a conjuntura político-econômica e cultural nos diferentes ciclos históricos característicos de cada país.

A generalização convencionada pelos estadunidenses, de que nos Estados Unidos os sindicatos são primeiramente instituições econômicas e no Brasil e México são primeiramente instituições políticas, tem seus méritos de acordo com os diferentes momentos históricos conjunturais.

A extensão de direitos aos acordos coletivos - designada juridicamente como erga omnes,$-{ }^{97}$ é garantida não só aos trabalhadores norte-americanos filiados aos sindicatos, mas a toda unidade legal de negociação.

No Brasil e México predominam os grandes sindicatos por ramo de indústria. Os sindicatos de alcance nacional prevalecem mais no México e menos no Brasil e são raros nos EUA, onde prevalecem os sindicatos de empresas de trabalhadores que elegem um representante legal para a negociação coletiva, o que caracteriza uma liberdade de escolha, ainda que, contraditoriamente, o governo não tenha ratificado a convenção número 98/1949, da Organização Internacional do Trabalho (OIT), organismo ligado à Organização das Nações Unidas (ONU), que versa sobre o direito de organizar-se e barganhar coletivamente, bem como a convenção 87/1948, que versa sobre a liberdade de associação e proteção do direito de organizar-se, dando margem a diferentes interpretações quando deliberadamente propagam a liberdade sindical como componente democrático, mas não a reconhecem de fato perante a comunidade internacional.

\footnotetext{
${ }^{97}$ Em relação a todos; a respeito de todos, sócios e não-sócios e estipulantes.
} 
No Brasil, a convenção número 87 aprovada, extraordinariamente, pela Comissão de Constituição e Justiça do Senado em dezembro de 2002, encontra-se em situação jurídica indeterminada por não se harmonizar com a Constituição de 1988 e aos interesses conservadores dos sindicatos dos trabalhadores. Este projeto de ratificação da convenção 87, que está em pauta desde o tempo do presidente Gaspar Dutra (1946 a 1951), necessita de retificação através de uma emenda constitucional (PEC), mas as discussões acirram-se em torno da unicidade e do imposto sindical compulsório que, para alguns, é ainda necessário e para outros não, pois nossa maturidade democrática já permitiria a liberdade sindical ampla sem imposições de espécie alguma. Ganha força a discussão da adoção do sistema sindical pluralista após a Convenção 87 da OIT que prevê a liberdade de organização dos trabalhadores, e a interpretação dominante considera restrição a esta liberdade a determinação de territorialidade como a base municipal e a proibição da coexistência de duas entidades sindicais para uma mesma base, bem como a necessidade de registro junto ao órgão competente público. A imposição que se verifica para a adoção de tal modelo não identifica as necessidades formais do trabalhador latinoamericano, mas as prerrogativas da globalização, pois os grandes países capitalistas disputam entre si os mercados globais em detrimento dos direitos sociais fundamentais e específicos dos trabalhadores em outras partes.

A tendência que se vislumbra, caso tal modelo seja contemplado, seria a de um aumento do já considerável número de sindicatos. A total autonomia na confecção dos estatutos, regulamentos e processos constitutivos dos sindicatos é o que determina tal convenção. O Estado em nada interfere quanto ao seu funcionamento administrativo, a não ser quando as leis não são cumpridas, pois determina que os sindicatos não podem suspender ou cessar suas atividades através de medidas administrativas e determina inteira liberdade para se associarem com entidades hierarquicamente superiores e organismos internacionais.

A interdependência entre os detentores do capital, do sistema jurídico-legal, do poder político e os diversos grupos de trabalhadores que formam os sindicatos, esboçam diferenças categóricas entre Brasil e México comparados aos EUA, quanto à organização, centralização e o relacionamento conflitante destes grupos. Encontra-se implícita nas leis trabalhistas básicas destes países a proteção ao trabalhador no seu direito de organizar-se, mas os procedimentos diferem-se bastante. No Brasil e México o status legal depende, 
ainda, do registro governamental. Nos Estados Unidos é a votação secreta dos trabalhadores, de acordo com o Wagner Act e sua regulamentação expressa na National Labor Relation Board (NLRB), que confere o status de representação dos trabalhadores nas negociações coletivas do trabalho.

Desde a década de 30, a maioria dos países latino-americanos já havia delineado suas leis de proteção ao trabalho como princípio básico de função social, sem considerá-lo simples objeto de comércio; ou seja, seguiam os princípios universais do direito do trabalho com proteção do Estado. Tais direitos do trabalho eram mais formalidades adstritas como parte do direito positivo do que a sua vigência propriamente dita. O que difere dos direitos conquistados no Brasil e México em relação aos Estados Unidos foi a outorga do legislador idealista latino-americano em contraste com o poder de barganha e pressões sociais dos sindicatos de trabalhadores norte-americanos. Os momentos são diferentes, pois os Estados Unidos foram partícipes importantes da primeira revolução industrial (1780/1820 - 3 a 4 decadas após a Inglaterra ter iniciado o processo), conquanto Brasil e México partícipes da segunda revolução industrial (1870/1910), o que determinou uma "industrialização secundária e acessória". No Brasil, dinamizou-se somente a partir de 1930.

A imposição neoliberal justifica, no Brasil e México, a tendência de negociação coletiva, de acordo com cada atividade econômica, que permanece restrita à empresa local, em detrimento de sua amplitude. Haja vista que, no Brasil, as grandes negociações coletivas de trabalho ocorrem nas regiões mais industrializadas, com tendência a se efetivar por empresas. No México, as zonas de "maquilas" caracterizam esta tendência e a presença dos contratos de proteção questiona a negociação coletiva, pois os sindicatos "pelegos" (blancos, charros) negociam contratos que favorecem somente os empregadores em detrimento de sua tradicional legislação laboral que assegura proteção, mas que ainda tem mostrado entraves históricos na sua execução.

Atualmente, o contrato coletivo de trabalho denota ser mais um instrumento maleável que precariza as relações de trabalho; tende a se propagar em detrimento de instituições que já foram consagradas. No entanto, a defasagem na aptidão e eficácia de tal desempenho na regularização das relações trabalhistas dependerá da reestruturação do sistema, em que a relevância das condições peculiares ao processo histórico do desenvolvimento cultural, social e econômico deveria estar "embebida" pelos 
fundamentos primordiais da nação. Ao contrário do que ocorre no Brasil e México, os sindicatos dos EUA organizam-se com unicidade na cúpula e pluralidade na base, todavia, um sistema que permitisse a pluralidade total, tanto na base quanto na cúpula, caracterizaria uma maior liberdade.

Os Estados Unidos, Japão e Comunidade Européia são os maiores agentes econômicos neoliberais na época da globalização. Qual o significado destes neologismos como "neoliberalismo", "aldeia global”, "fábrica global”, "mundialização dos mercados financeiros", "telecomunicação global" e a "transnacionalização da produção" subentendidos na palavra globalização ${ }^{98}$ ?

O "neo" do liberalismo econômico significa a imposição rígida das poderosas instituições financeiras acopladas às transnacionais, consoante com a rapidez da evolução tecnológica num mundo informatizado e "liberal" e, por conseguinte, transmuda o enfoque do liberalismo clássico, que se fundamenta na Escola Austríaca de Economia superconservadora de Hayeck ${ }^{99}$, com a predominância teórica de mercado livre que se transfigura no descontrole da empresa pós-moderna e seu capital transglobalizado que vem, justamente, caracterizar a incipiência de um sistema. É devido às constantes crises econômicas, com queda do lucro, que se tem vivificado nas elites corporativas a suposta eficácia dos mercados, livres de ingerências políticas ou outros óbices quaisquer, evidenciando a praxe histórica desde há muito tempo, com um mínimo de preocupação social e ambiental.

A palavra "neoliberalismo" é pouco usada nos EUA e conota mais um estilo de política externa, diferente da acepção latino-americana de mercados globais e políticas de livre comércio afinadas com os interesses dos grandes países capitalistas. Entretanto, mercado e comércio livres não são novidades, mas nas economias capitalistas avançadas tais relações sofisticaram-se e, apesar de ser um fenômeno das democracias ocidentais ricas, seus efeitos são maiores na intensificação da pobreza e riqueza em geral e com particular intensidade nos países menos conscientizados quanto à possibilidade estrutural genuína do seu desenvolvimento próprio livre das amarras de um capitalismo alquebrado.

\footnotetext{
98 O comércio global sempre existiu sob diferentes formas, mas hoje com o domínio "das grandes corporações transnacionais" é o que fundamentalmente caracteriza a globalização, segundo Octavio Ianni em entrevista concedida a globaliation.org., s.d.

99 Friedrich August von Hayek (1889-1992) com o seu livro "The Road to Serfdom" (O Caminho da Servidão), de 1944, crítico contumaz dos meios de regulação do Estado na economia.
} 
Este novo paradigma produtivo tem sido imposto como uma fatalidade de tendências hegemônicas globais e tenta explicar os diversos fenômenos que o envolvem, como a capacidade de trabalhar uma unidade em tempo real e em escala mundial dentro de único mercado internacional de finanças mais o papel pró-ativo das corporações transnacionais num contexto de acirrada concorrência lesiva à saúde econômica e ambiental do conjunto da economia global, em contraste com a pouca mobilidade da mão-de-obra.

O que foi a industrialização para o século XIX, ocorre hoje com o fenômeno da globalização ou mundialização, um novo ciclo de expansão do capitalismo em que tudo se move (coisas, gentes e ideais) em função do capital transnacional, ultrapassando "fronteiras geográficas, históricas e culturais", todavia bem mais dinâmico e ativo, mais condizente com esta época de céleres mudanças. Ou seja, a essência continua a mesma, mas a temporalidade ajustou-se às características contemporâneas. Com o advento do mercantilismo, colonialismo e imperialismo as regras mudaram de fantasia, mas a essência permaneceu a mesma; justamente por isso, percebe-se notoriamente que não tem havido progresso humanitário tampouco uma cultura de paz capazes de desenvolver as potencialidades latentes do ser humano para que se cumpra o papel reservado a ele no cosmos, ${ }^{100}$ na acepção filosófica grega de oposição ao caos.

Todavia, os países mais desenvolvidos precisam compreender ${ }^{101}$ e não só entender, os paises em vias de desenvolvimento, que numa primeira vista pode parecer não tão óbvio, pois não temos a desenvoltura e recursos para competir com igualdade com o dispendioso, sofisticado e complexo modelo das economias capitalistas avançadas e, em particular, a norte-americana, quanto ao sistema de medidas judiciais objetivas e pragmáticas e os poderosos lóbis que influenciam em excesso a sua economia política.

O que dizer quanto a objetivos como a promoção dos direitos humanos, direitos trabalhistas e o meio ambiente. Estes itens crescem em importância nos debates públicos relativos à globalização e instituições multilaterais. Não se pode deixar que simplesmente sejam negligenciados, colocados de lado em nome da primazia dos fatos puramente comerciais, que vêm ocupando o centro das atenções das negociações internacionais.

\footnotetext{
${ }^{100}$ Do grego "Kósmos" que significa ordem, organização, conveniência.

${ }^{101} \mathrm{Na}$ acepção etimológica do termo: de uma consciência ampla (com...), holística. O entendimento é linear de limitada interação e a compreensão é não-linear e, por isso, de interação mais ampla e dinâmica e capaz de deslindar as potencialidades humanas.
} 
O grande duelo que Brasil e México têm pela frente é o de tentar mitigar o grande desequilíbrio na distribuição da renda social entre uma minoritária elite, que detém o poder político/econômico, e a grande maioria que não dispõe do mínimo para poder partilhar. Os problemas sociais e políticos são muito semelhantes, pois a história demonstra que a exploração colonial, processos de independência e consolidação nacionais são bastante próximos.

O que devemos salientar aqui é a miscigenação característica dos povos brasileiro e mexicano, cada qual com suas especificidades, estando em processo constitutivo o molde do arquétipo mundial ${ }^{102}$ que, permitam-me ser utópico nesta finalização, surgirá de um sopro da capacidade inigualável de universalidade do povo mexicano e que servirá de baluarte para a construção da Cosmocracia!

\section{Estados Unidos}

A união AFL/CIO, em 1955, foi um dos eventos marcantes da história moderna norte-americana e decisiva para se compreender os fundamentos interativos estabelecidos pela fusão econômica com os atores envolvidos, principalmente para a perspectiva neoliberal dos dias atuais. Foi concebida por premissas voltadas não só aos interesses econômicos e sociais dos trabalhadores, mas para propugnar o bem-estar geral da nação. A fusão como processo dinâmico sugere que as diferenças nos propósitos, estruturas e métodos de operações entre a federação e as atuais fusões corporativas não são tão diferentes assim, na sua essencialidade. Evidências históricas do sindicalismo norteamericano permitem afirmar que estas coligações, quanto as suas respectivas jurisdições, têm reduzido a sindicalização e o próprio debate democrático. A ferramenta principal de luta, o Contrato Coletivo de Trabalho, propalado pela federação, hoje não mais condiz com os fatos da realidade econômica, distanciando-se, cada vez mais, dos anseios de trabalhadores mais conscientes. Os sindicatos agem de modo reacionário às imposições neoliberais de fusão corporativa, adaptando-se às modificações destas neocorporações que resultam numa estrutura de capital mais consistente com o crescente mercado competitivo, em detrimento da sua função social. A AFL/CIO tem conduzido sua política

${ }^{102}$ Como se refere o escritor mexicano José Vasconcelos na sua obra denominada "Raza Cósmica". 
sindical na base do consenso, tática válida nos anos anteriores à $1^{\text {a }}$ Guerra Mundial até pouco após a $2^{\mathrm{a}}$ Guerra Mundial em que o clima de união nacional, o firme crescimento econômico e as concessões governamentais pró-sindicato intercederam a favor daquela tática, que hoje não mais condiz com aquela conjuntura e, portanto, limita suas perspectivas com a dissensão.

Uma melhoria no panorama para o setor sindical privado vai exigir uma mudança radical no que os sindicatos fazem e inovações estruturais mais voltadas ao ser humano, o que parece, cada vez mais, relegado ao segundo plano, como resultado da crescente introdução de novas tecnologias no local de trabalho. $\mathrm{Na}$ atual fase neoliberal do capitalismo, cuja forte concorrência dita as normas de mercado, será necessário repensar a situação econômica conflitante da diminuição dos lucros nas empresas mais sindicalizadas, algo importante para se chegar à harmonização do conflito. Um prérequisito para valorizar o trabalhador será organizar-se em nível mundial nos mesmos moldes como foi estabelecido nos sindicatos nacionais, como maneira deliberada de conter a total falta de controle nas atitudes das corporações transnacionais para com os trabalhadores nas diversas partes do mundo, opinião compartilhada por muitos líderes sindicais.

Nos últimos dois séculos, o rápido crescimento tecnológico na área industrial manufatureira norte-americana levou o trabalhador a altos salários e padrão de vida crescente, mas, nos últimos 60 anos, está havendo uma redução da mão-de-obra manufatureira (mais artesanal) nos países de economia avançada e pioneira deste setor. Nos EUA, esta porcentagem vem declinando, pois, em 1960, os trabalhadores das indústrias manufatureiras representavam $25 \%$ e hoje não passam de $12 \%$ da população economicamente ativa (PEA). A fonte da prosperidade norte-americana não é mais a indústria manufatureira que, paulatinamente, foi se mudando para países de mão-de-obra mais barata devido às chamadas indústrias multinacionais e transnacionais, como é o caso das zonas "maquiladoras", mais comuns nos espaços geográficos próximos às zonas fronteiriças. O que se comprova é, pois, a efetivação deste processo desde há muito tempo, sendo que na atualidade, não há necessidade de espaços geográficos contíguos, dado que a globalização no enfoque neoliberal desconhece fronteiras, graças à moderna tecnologia e sistemas organizacionais mais complexos. 
Hoje, a maior economia do mundo está direcionada incessantemente para a economia de serviços em que a inovação em alta tecnologia e outros serviços altamente profissionalizados são as modernas fontes de prosperidade. A alegada proporção de cada emprego gerado no México corresponderia à geração de 2 ou mais empregos nos USA, como se dizia coisa de um ano e meio após a assinatura do NAFTA (North American Free Trade Agreement); o que é plenamente aceitável e está confirmado pelas estatísticas de ambos países.

O NAFTA, ou, como quaisquer acordos capitalistas impostos de cima para baixo, tem sido um ponto positivo para a Economia dos EUA, pois, apesar de os trabalhadores no sul dos EUA terem perdido milhares de empregos nas industrias têxteis e de móveis para os trabalhadores mexicanos de salários mais baixos, a grande maioria dos trabalhadores estadunidenses que perdeu seu emprego, muito rapidamente, foi empregada em empresas de alta-tecnologia, de modo que tiram dupla vantagem com a localização geográfica estratégica destas novas fábricas nas cercanias da área de livre comércio, ou seja: baixos salários para os trabalhadores menos especializados e emprego para o desempregado norte-americano em áreas de tecnologia de ponta. Isto de acordo com o programa do Departamento de Trabalho Americano (NAFTA-TAA) de assistência aos que perderam seu emprego por causa do acordo. O crescimento das exportações, inclusive para o México e Canadá, tem garantido o suporte para o crescente aumento da oferta de emprego.

Pesquisas de opinião pública indicam que $60 \%$ dos norte-americanos consideram que o NAFTA tem sido prejudicial para os empregos nos EUA, enquanto que $70 \%$ dos mexicanos consideram que os Estados Unidos têm sido muito mais beneficiados por este acordo capitalista (México e o Mundo: Visões Globais - 2004).

Para que a incorreção na interpretação das análises dos dados estatísticos diminua, é preciso ter sempre em mente os fundamentos do cientificismo da classe dominante, que tem pouca relação com as funções sociais primordiais da sociedade, porque os interesses econômicos embutidos na suposta neutralidade científica possuem fins escusos, o que não contribui para a isenção da classe verdadeiramente científica, que se preocupa com o papel social das ciências. O aspecto significativo do pensamento científico tem estado interligado à sua contrapartida econômica. $\mathrm{O}$ desenvolvimento tecnológico, em princípio, pode não estar relacionado às finalidades comerciais, mas com 
a intervenção pragmática da utilidade pela qual tal objeto se propõe, transforma-se em bem econômico e se sujeita às leis de mercado. Faz-se imprescindível pensar a crítica dos métodos utilizados pelos investigadores científicos, assim como dos fins a que se destina o que produzem, para que algo que é benéfico, em princípio, não seja desvirtuado $\mathrm{A}$ História, neste caso, vem a ser utilizada eficazmente para desmistificar o conteúdo real na produção do conhecimento e a acaba por ocupar um lugar de proa.

A coexistência pacífica entre o mercado econômico e a sociedade civil nunca foi tranqüila, pois o mercado global movimenta capitais financeiros, novas tecnologias e diferentes mercadorias sem limitações ou pouco controle conquanto as pessoas têm, no direito humano de ir e vir, restrições que se intensificam na atual fase.

Os 48\% do Produto Interno Bruto mundial dos USA, por volta de 1948, para a participação hoje de $22.5 \%$, de acordo com relatório do Banco Mundial, demonstra a fragilidade a que se expõem com a diminuição da quantidade de dólares disponível para os programas sociais. Está em jogo a sobrevivência do bem-estar social criado durante longos anos, desde Roosevelt e que agora enfrenta o sistema de globalização, que tem se tornado condição sine qua non da supervivência da maior potencia econômica do globo.

Foi a partir do final dos anos 60 que começou a surgir uma maior indisposição entre os sindicatos e as empresas; quando começaram a perceber as novas necessidades dos trabalhadores é que se criou um ponto de indiferença nessas relações.

Com a persistente perda de força dos sindicatos privados, as regras estabelecidas nos contratos coletivos tendem a torná-los sujeitos a uma paulatina transformação dos tradicionais contratos coletivos por sentenças normativas proferidas pelos foros judiciais (labor courts) - outrora negociados à mesa com os patrões. A sinalização de que tal procedimento vem se efetivando com a transformação dos modos de produção nacionalizados em transnacionalizados evidencia-se com a descaracterização das leis de proteção nacional, o que sugere uma nova fase de relações trabalhistas globais, a ser mais bem desenvolvida.

Tal fato remete-nos à indisponibilidade real com que os CCT estão sendo conduzidos e que, paulatinamente, precariza as verdadeiras e democráticas históricas relações trabalhistas estadunidenses.

As disputas trabalhistas são decididas, tradicionalmente, em foros distintos daqueles das disputas civis, apesar de certa tendência notada mais recentemente, para 
foros especificamente trabalhistas (Labor Courts), denotando uma interessante tendência de mudança de comportamento da Justiça estadunidense. Esta evidência começou a ser observada após o processo denominado Gilmer versus Interstate/Johnson Lane Corporation, ${ }^{103}$ pois a Suprema Corte determinou que a Lei Federal de Arbitragem (Federal Arbitration Act - FAA) tem favorecido, em alguns casos, a uma política liberal nos acordos arbitrados, questionando o Poder Legislativo sobre tal lei que tem impedido aos empregados interpelações nas questões dos fatos arbitrados, destacando que o árbitro tem poder para habilitar práticas discriminatórias de emprego. Cláusulas da lei em que as queixas discriminatórias podem ser contestadas na Suprema Corte de Justiça.

Esta tendência tem feito crescer a participação da NLRB na descaracterização das negociações coletivas, com o respectivo aumento da intervenção governamental na emissão de novas leis e entidades de competência sobre:

- $\quad$ Segurança e saúde ocupacional (Occupational Safety and Health Administration OSHA); que corresponde à Fundacentro no Brasil.

- $\quad$ Aposentadoria, pensões (Employee Retirement Income Secutiry Act - ERISA); que corresponde, no Brasil, ao INSS.

- Comissão de igualdade e oportunidades de emprego (Equal Employment Opportunities Commission - EEOC).

- $\quad$ Family, Medical Leave Act - Licença para tratamento médico sem pagamento, etc.

A multiplicação das leis tem aumentado a participação dos advogados e o recurso a elas, com uma quantidade de emendas que têm servido mais para regulamentar sua profissão nestas novas tarefas, do que a resolução das controvérsias. O fato é que cresceram os casos nos quais a NLRB tem tido que apreciar o reconhecimento expresso da entidade sindical em detrimento da negociação coletiva propriamente dita.

A arbitragem e a mediação, outrora figuras sem as quais não se imaginaria o desenvolver de uma negociação de dispensa sem justa causa, hoje estão tendendo a serem decididas judicialmente nos Fóruns, não como matéria laboral contratual, mas de alçada cível. Como a sua curta temporada na legislação trabalhista propriamente dita em meados

\footnotetext{
${ }^{103}$ Acordo para um arbitramento obrigatório (1991) para todas as disputas trabalhistas, na qual o empregado pode pleitear direitos sob os mandamentos da lei "Age Discrimination in Employment Act".
} 
do século passado e mais recentemente nos últimos 30 anos e, portanto, sem uma tradição de constância neste campo legal, agem paradoxalmente ao bom senso e tendem a conduzir as relações trabalhistas a um impasse sem precedentes dando azo a ideologias mais radicais.

As diferentes leis estaduais não permitem a celebração de um Contrato Coletivo de Trabalho para cerca de 8 milhões de trabalhadores nas diversas repartições públicas de 14 estados. No setor industrial e comercial privado (trabalhadores na construção civil, restaurantes, bares, prédios etc.), agricultura e trabalhadores domésticos (grande parte emigrantes em situação ilegal) abrangendo aproximadamente 27 milhões de pessoas que não têm o mínimo de segurança social em termos, principalmente, de plano de saúde e aposentadoria. As campanhas anti-sindicato são exaustivamente deliberadas no sentido de pressionar os trabalhadores a votarem contra a formação do sindicato e outras técnicas já aludidas no presente trabalho. Estes tipos de intimidação cobrem cerca de $51 \%$ das tentativas de organização dos trabalhadores. Caso os trabalhadores ganhem uma eleição para a formação de um novo sindicato, o supervisor usa de todos os meios possíveis para atrasar a negociação do primeiro Contrato Coletivo de Trabalho. Nestes casos, a tão propalada lei forte do NLRA torna-se inócua desde que sua execução não é cumprida de acordo com o que originalmente se propusera, ou seja, igualdade de condições e proteção contra pressões anti-sindicais, contrastando o verdadeiro princípio da boa fé e sua prática efetiva. Na realidade não existe uma padronização específica de como determinar se tal conduta é de boa fé, analisa-se o conjunto das ações e se determina em que circunstâncias as partes tentam chegar a um bom termo em se comparando com exemplos de negociações coletivas exemplares. Sob as aparências de uma negociação severa, o que é muito comum e legal, poderia uma das partes estar protelando a contenda para dificultar um acordo, o que caracterizaria uma conduta de má fé.

O engajamento do empregado no domínio do local de trabalho faz-se através de diversas formas de co-participação administrativa e, historicamente, tem proporcionado a coleta de informações que a gerência, habilmente, usa na prevenção de seus amplos interesses, como os movimentos paredistas e de solidariedade.

A jurisdição pela qual se subentende o posicionamento de um contrato coletivo do trabalho (CTT) no campo jurídico, como uma espécie de instrumento regulador ou mediador com forte compleição legal, mas com pouca ou quase nenhuma força coercitiva 
de facto, baseando-se somente em advertências, recomendações ou conselhos, tem sentido somente numa visão estritamente econômica, pois os aspectos de legalização e validação para a efetivação de benefícios sociais relevantes à classe trabalhadora tendem a se tornar cada vez mais abstratos.

$\mathrm{O}$ direito que regulamenta as relações de trabalho teve um crescimento significativo relacionado com o expressivo desenvolvimento econômico, sendo que, a partir dos anos 80, alguns juízes e tribunais de alguns estados começaram a impor limites à demissão involuntária, contrariando a lei "Employment at will", ${ }^{104}$ mas de maneira muito formal e controversa, pois desde de 1877 e baseada numa regra sem fundamentos jurídicos claros, os tribunais adotaram-na como lei ordinária.

A despeito do que se tem realizado em prol da garantia dos direitos trabalhistas, a usurpação praticada pelo crime organizado tem descaracterizado os contratos coletivos do trabalho:

- com a venda de acordos previamente estabelecidos em conluio com os empregadores (sweetheart);

- $\quad$ com desfalques dos fundos de pensão dos trabalhadores;

- $\quad$ com o estabelecimento e organização de cartéis; e

- $\quad$ com a eliminação de todos aqueles que, porventura, fossem contra seus fortes argumentos de intimidação.

\footnotetext{
${ }^{104}$ Os empregados nos E.U.A. são divididos em duas classes: 1. Employment at-will: podem ser demitidos a qualquer momento, com ou sem justa causa e, comumente, sem intervenção do tribunal para a defesa do empregado supostamente injustiçado. 2. Just-case employees: só podem ser demitidos por justa causa.
} 


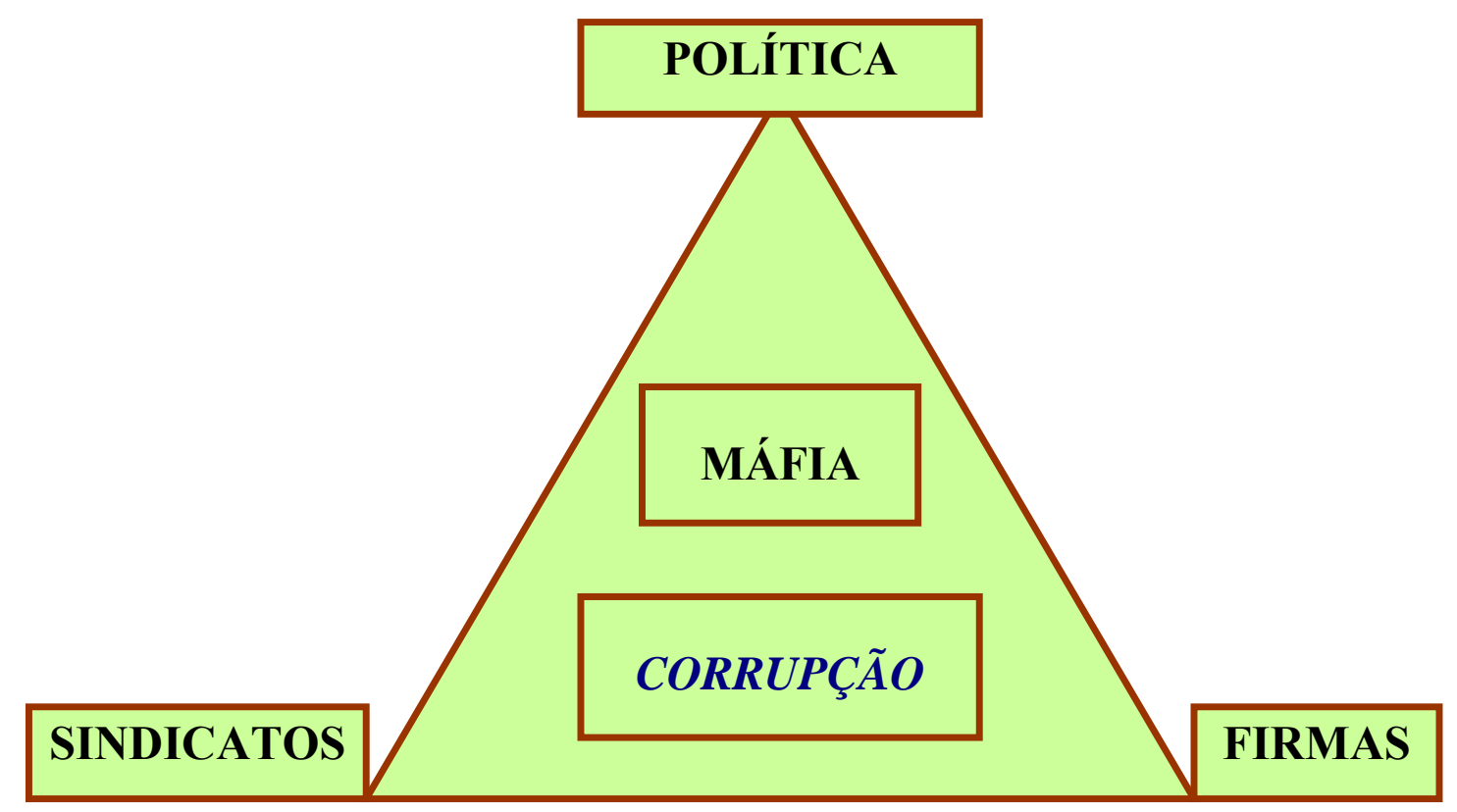

O impacto ambíguo que a depravação de hábitos e costumes tem provocado nas sociedades caracteriza-se pela dominação da ilegalidade e uma das características mais proeminentes do movimento trabalhista estadunidense tem sido a dificuldade em determinar a especificidade que a dinâmica do crime organizado tem tido sobre o movimento trabalhista e a sociedade.

A conclusão é simples para os fatos complexos, pois envolvem a capacidade que grupos organizados têm ao exercer o controle imperativo sobre certos segmentos da sociedade. As dificuldades inerentes à investigação dos grandes e diversos interesses envolvendo o poder são, freqüentemente, ocultas, vagas, ambíguas, irresolutas, confusas e imprecisas, pois tal condição de continuidade indefinida condiz com os interesseiros e o desconhecimento da verdade, retarda o conteúdo essencial e tende a conduzir a caminhos ilusórios, contradizendo a sua própria constituição, que tão bem os alerta contra tais atitudes quando manisfesta críticas internas tipo: "não é mais o governo do povo, pelo povo e para o povo, mas se tornou o governo do dinheiro, pelo dinheiro e para o dinheiro".

O envolvimento do crime organizado nas relações do trabalho ainda persiste, pois, de acordo com o relatório de 2003 do Office of Inspector General's (OIG's), existem 141 casos abertos envolvendo, aproximadamente, um montante de US\$28.000.000,00 entre restituições e confiscos, com 182 acusações e 123 condenações. A maior parte das 
condenações ainda envolve membros de "La Cosa Nostra", bem como um crescente envolvimento de organizações do crime não tradicionais e muito sofisticadas no seu modus operandi com o uso de modernas tecnologias informatizadas.

Os planos de pensão, com mais de 400 bilhões de dólares em ativos, são administrados pelos sindicatos e membros do conselho diretor das empresas, entretanto, um estudo em 14 planos de um total de 110 demonstrou várias irregularidades. 


\section{O PROCESSO DE NEGOCIAC̄̃̃O COLETIVA DO TRABALHO}

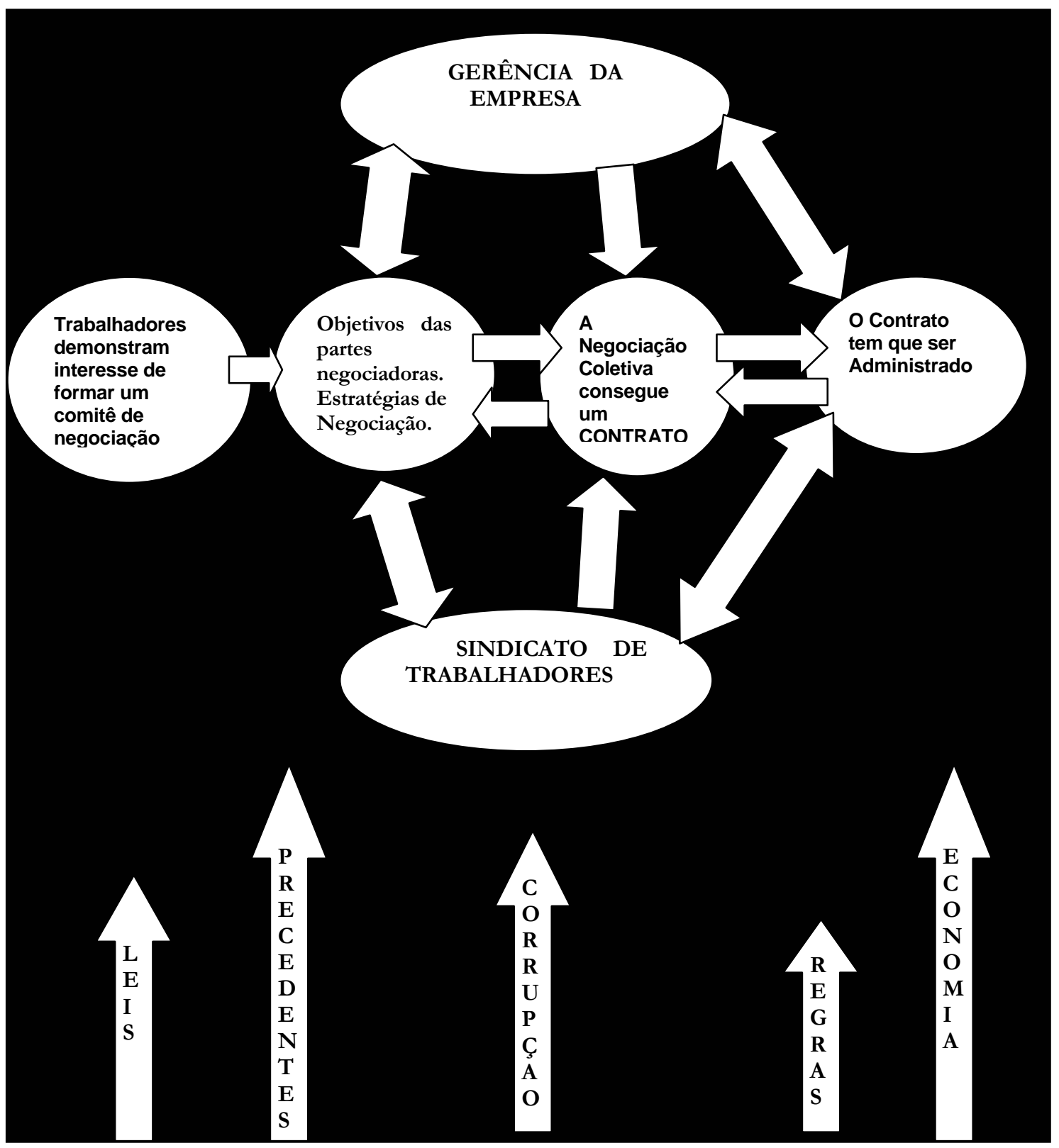




\section{México}

Gunnar Myrdal ${ }^{105}$, que conheceu a fundo os problemas do subdesenvolvimento, demonstrou distinta previdência quando, há 42 anos, expôs:

Como veremos, é isto o que acontece com a teoria do comércio internacional. Esta teoria, na verdade, admite que o comércio provoque um movimento no sentido da equalização da renda; no entanto, em vez disso, o comércio sem controle entre dois países, um dos quais industrializado e o outro subdesenvolvido, desencadeia um processo acumulativo tendente ao empobrecimento e à estagnação desse último país.

Pois é exatamente o que caracteriza a produção transnacionalizada do sistema neoliberal e tem acontecido não só no México, mas onde tal relação de reciprocidade se evidencia. O controle do comércio internacional tem estado mais afinado com os grandes interesses corporativos, pois é a própria essência da natureza capitalista mais avançada.

O conturbado sindicalismo mexicano, nos momentos de transição política, nunca foi coerente com a unificação que lhe daria força para vencer as crises, pois a divisão em diversas correntes acaba por atenuar os propósitos pelos quais lutam. Aliás, desde a época anterior à conquista, tal conceito de unificação não se faz representado, ainda que pudesse resultar numa perspectiva altaneira de solução para seus desencontros.

O movimento trabalhista mexicano durante os anos 30 do século XX teve um cenário próximo ao do Brasil, pois as características corporativas de controle dos trabalhadores dentro de um modelo de industrialização secundária baseada na substituição de importações são coincidentes na evidência de uma burguesia afinada com a padronização colonial.

O longo tempo de lutas, especificadas acima, explicitou, ainda mais, as divisões do movimento trabalhista com o desdobramento do Congresso do Trabalho (CT) na formação de trabalhadores que, descontentes com a situação, autodenominaram-se "foristas". Esta frente nacional do trabalho discutiu a maneira pela qual seria conveniente a atuação dos trabalhadores para enfrentar as prolongadas crises irresolutas donde proviria

\footnotetext{
${ }^{105}$ Economista sueco (1898/1987), prêmio Nobel de economia de 1974. Prêmio Nobel da paz em 1982 que compartilhou com o mexicano Alfonso García Robles.
} 
a formação, em 1997, da União Nacional dos Trabalhadores (UNT). O “forismo" buscou um novo pacto com o governo através de sua militância sindical sem, contudo, aliar-se a nenhum partido político na sua determinada luta contra o sistema neoliberal.

Esta tem sido uma característica dos países latino-americanos ainda atrelados ao neocolonialismo e junto aos notórios aconchavos de uma minoria nacional subserviente que detém o prestígio e domínio e que, se se torna abastada, acomoda-se em berço esplêndido e perde toda uma perspectiva promissora de desenvolvimento econômico com maior sustentabilidade e o resultante bem-estar social para a grande maioria da população. Exemplo ilustrativo de tal afirmação são os casos das ferrovias no Brasil e México, como resultado principal no transporte dos produtos de exportação agrários, das quais as industrializações secundárias beneficiaram-se de economias de escala, mas cujas decadências precoces têm sinalizado contra-sensos ímpares, mesmo considerando o baixo custo deste tipo de transporte que ocasionaria uma economia mais sustentável, caso continuassem dela a fazer uso mais intensivo, como têm sido os casos de países que tiveram o empreendimento inicial deste investimento e que até hoje lhes trazem ótimas taxas de retorno e de manutenção de empregos.

A legislação laboral que se iniciou em 28 de agosto de 1931, foi remodelada a partir de primeiro de maio de 1970, com a respectiva mudança no direito adjetivo, ${ }^{106} \mathrm{em}$ maio de 1980. Aquilo sobre o que dispunha o artigo 16 da lei federal do trabalho (LFT), de 1931, eram os casos não previstos pela LFT que se resolveriam de acordo com o costume, uso e eqüidade, autorizando, expressamente, o uso suplementar do direito comum. O artigo 17, da nova LFT de maio de 1970, omite o uso suplementar do direito comum como fonte do direito do trabalho, aproximando-se mais do modelo pragmático estadunidense. Observa-se que, gradualmente, os direitos adquiridos em matéria laboral, quando se recorresse ao direito comum ou a quaisquer outras fontes para assegurar a cidadania, estariam direcionados à efetivação do novo sistema neoliberal de relações de trabalho com ênfase nas observações contratuais como fonte deste direito. A força econômica, via de regra, sobrepuja-se aos direitos humanos fundamentais. Aquilo que vale para a economia, como característica local e temporal peculiares para uma melhor eficiência, não vale para o direito do trabalho que tem como característica, também, sua localidade e temporalidade específicas para conquistas de liberdades cidadãs, dentre as

${ }^{106} \mathrm{O}$ direito adjetivo torna efetivo o exercício regular das relações definidas no corpo fundamental da legislação. 
quais, uma distribuição mais eqüitativa das riquezas produzidas e a valorização de um direito fundamental do homem que é o direito ao trabalho. A lei federal do trabalho (LFT) que tem procurado regulamentar o artigo 123 da Constituição Mexicana, que, a princípio, não deveria suplantar os preceitos constitucionais, mas que na prática, tanto o Estado como a elite empresarial, violam-nas em suas relações individuais ou coletivas de trabalho, prática, aliás, muito comum alhures onde o termo "Contrato Coletivo" não condiz com sua acepção autêntica de jogo livre e justo entre partes conflitantes.

As características de uma industrialização secundária consistem em não ser competitiva, usar ora tecnologia ultrapassada oriunda da desativação de maquinários do país sede, tecnologia inadequada por conta dos modernos maquinários importados e em uso nas zonas "maquiladoras", de possuir tendências oligopólicas e de estar voltada somente ao mercado de consumo nos setores mais dinâmicos, mas não na implantação de um mercado de bens de capital que são bens que servem para a produção de outros bens como, por exemplo, as instalações de uma autêntica indústria nacional que atendesse aos interesses prementes da sociedade sem deixar que se ofusque o discernimento essencial para transformações sociais visando o bem-estar da população mais sofrida.

A intenção não tem sido a de desenvolver o seu mercado interno, nem mesmo a de amenizar a falta de eficiência dos trabalhadores mexicanos, mas volta-se ao mercado exportador com o uso de maquinários sofisticados importados do país sede onde o custo do trabalho é maior em dezenas de vezes. Tais aspectos evidenciam que estas implementações têm sido frutos de políticas econômicas despropositadas que, aliada às corporações financeiras internacionais em conluio com a oligarquia nacional, têm conduzido a economia mexicana a constantes desacertos.

A ratificação do convênio 87 em 1950, sobre liberdade sindical e proteção ao direito de sindicalização, contrasta-se com a não ratificação do convênio 98 sobre o direito de sindicalização e negociação coletiva. O verdadeiro CCT deve estabelecer critérios autênticos para não refletir certos privilégios a uma elite sindical, mas garantir os direitos consagrados dos trabalhadores no geral.

Com a rápida mudança na conjuntura econômica mundial comandada pelo neoliberalismo, a prioridade nos países que mais sofrem as más conseqüências, não deveria ser a de uma melhor adequação a este modelo, com uma maior flexibilização dos contratos anteriormente consignados, mas uma atuação mais de acordo com uma 
transformação desta situação condizente com a realidade econômica e social criada por aquela configuração. Esta política tem minimizado todos os aparatos que poderiam defender a sociedade, a começar pela política nacional (privatizações em vez de reforço de indústrias autênticas), sindicatos de trabalhadores (imposição do Contrato Coletivo de Proteção, em vez de maior ênfase nas reformas do direito trabalhista no sistema jurídico nacional) e, mais recentemente, o enfraquecimento do poder judiciário, na tentativa de flexibilização para posterior desregulamentação de políticas públicas autênticas, direitos trabalhistas adquiridos e precarização dos serviços públicos como a educação, saúde e previdência. Consiste em um plano de longo prazo cujas variáveis são devidamente implementadas e concretizadas com base num processo sofisticado de informações, com a utilização de técnicas de eficiência comprovada para o mercado de interesses capitalistas.

As próprias corporações são aliadas dos governos hegemônicos na sua função de gerar maior acumulação de capital para firmar um imperativo categórico de sujeição; tais conglomerados capitalistas, especializados em maquinações políticas, têm agido desde a época da industrialização, mas a sofisticação com que hoje se revestem na luta pelos seus interesses privados é fenomenal. Por exemplo, no aspecto contábil, as corporações são regulamentadas pelos governos, de modo a terem um passivo limitado, ou seja, suas responsabilidades são adstritas ao montante investido e negociado em bolsas de valores, dando azo, portanto, a todo tipo de especulações imagináveis sem maiores compromissos, e no anonimato.

Tendo passado por mais de quatro centenas de reformas, desde a sua promulgação, a constituição mexicana de 5 de fevereiro de 1917 vem sendo desenvolvida dentro de uma cultura reformista que tem produzido, contemporaneamente, tensões políticas e sociais agravadas basicamente por conflito de interesses entre os argumentos da política neoliberal, de um lado, e a interferência do Estado na economia, de outro. Do ponto de vista constitucional, ainda que legítima, nos últimos anos sua competência e eficiência vem sendo fortemente questionada. 


\section{Brasil}

A educação, quando devidamente efetivada, tem sido o baluarte da lei e da ordem.

Verifica-se um misto de influências de diversos receituários moldando o contexto trabalhista brasileiro desde o anarcossindicalismo, ação política manifestada na França no fim do século XIX, que exerceu domínio junto aos trabalhadores brasileiros no início do século XX, trazido pelas primeiras levas de imigrantes vindos da Espanha, Portugal e Itália. O surgimento nas décadas de 1920/1930 do regime fascista na Itália e outros movimentos semelhantes na Alemanha, Espanha, Portugal, tivera como característica o cunho autoritário e corporativista. Com o processo de desenvolvimento industrial promovido pelo governo de Vargas, as bases de uma legislação trabalhista, inspirada em parte pela Carta de Lavoro de Benito Mussolini, foi instaurada. Toda uma gama de fatores espaciais e temporais, implícitos e explícitos, combinou-se e foi determinante para grau de desenvolvimento econômico e social que se complementaria dando as características peculiares que têm identificado o modelo brasileiro de relações de trabalho.

O surgimento de novas instituições, conforme decreto federal $88.984 / 83,{ }^{107} \mathrm{em}$ ano de forte ação persuasiva junto aos atores competentes, denota vigorosa conotação de interesses capitalistas excludentes com o incitamento da ação "flexibilizadora" contraditória com a premissa maior da prática disciplinadora da CLT que, embora defasada, não deveria deixar de ser o instrumento determinante para a defesa do hipossuficiente, que caracteriza a maior parte dos trabalhadores brasileiros. É imensa a distância que separa a lei protecionista da realidade nas relações de trabalho, haja vista os mais de $60 \%$ de trabalhadores na informalidade. Quando as contradições entre a lei soberana e os valores dominantes sobrepujam a expectativa conciliadora, sobrepõe-se a crise que se anuncia com imposições de domínio político-econômico sobre a eficácia e a legitimidade da verdadeira lei que tem o dever de proteger os trabalhadores menos favorecidos dos óbices de um capitalismo tardio. Como protegê-los de maneira mais eficaz, se considerarmos que a nação não fez acumulação primitiva de capital e tem feito

107 Constituiu os Conselhos (Federal e Regionais) de Relações do Trabalho e o Serviço Nacional de Mediação e Arbitragem. 
uso inadequado daquele que toma emprestado? A lei enérgica (fiscal e trabalhista) acaba por desassistir não só a regulamentação do empregado, mas as próprias empresas, mormente as de menores portes, legando-os à informalidade. Trata-se de uma situação delicada, pois a eficiência do sistema concentra-se nas grandes empresas ligadas a sindicato forte, que são as que mais adotam medidas flexibilizadoras para atender ao aguçamento das concorrências - quase sempre desleais - entre as quais, a do mercado internacional, livre de quaisquer ingerências reguladoras no contexto da nova configuração da divisão internacional do trabalho. De um lado, nas grandes empresas, com as gerências bastante qualificadas que se convertem para uma situação individualista exacerbada, no que são respaldadas, por bons contratos e altos salários; de outro lado, nos sindicatos, em que se desvanece a consciência de classe operária e o companheirismo que os caracterizavam. Com isso, o sindicalismo combativo que tinha na unidade a sua força de luta, tende a se enfraquecer e vai-se perdendo toda a perspectiva de luta coletiva dos trabalhadores.

A partir da recessão dos anos 90 do século passado, o Brasil tem vivenciado sua pior crise na criação de empregos, que são frutos de séries de políticas equivocadas desde o retrógrado modelo de industrialização, cópia mal feita daquilo que, há cem anos, estava sendo feito de maneira própria e genuína pelos países desenvolvedores de tecnologia, sem mencionar o compasso de espera e a relutância em se livrar da escravidão, cuja imagem identifica uma das piores distribuições de renda do planeta.

O desemprego que atingia apenas os mais pobres, hoje atinge igualmente a todas as classes, evidenciando que a falta de uma maior autonomicidade, no sentido de estarem livre de influências subjugantes e desígnios impróprios, fatalmente, tende a conduzir a economia para este estádio de acontecimentos. Desde a proclamação da República até o fim da ditadura militar, o Brasil tem crescido vigorosamente, mas, nem por isso, parte da sociedade foi incorporada ao mercado de trabalho. Neste início de século de política neoliberal, outros indícios de mudança a serem considerados nas análises, referem-se à diminuição da taxa de natalidade, que já está pouco abaixo da taxa mínima de reposição populacional que é de 2,1 filhos por casal (nos anos 60 era de 6,2), variante a ser apreciada como fator demográfico, e que deveria, em princípio, melhorar as relações de trabalho e oferecer educação de qualidade, no que diz respeito ao seu impacto na atual conjuntura político-econômica. 
Nem as reformas clássicas aplicadas a um capitalismo secundário e acessório poderiam ser devidamente efetivadas, pois já conceituadas e passíveis de verificação, é comprovado que:

- $\quad$ a justa distribuição de terras aumenta a produção sustentável e diminui a migração para centros urbanos;

- a reforma fiscal possibilita uma mais justa transferência de rendas ao mais pobres;

- a educação básica, como parte de uma reforma social mais ampla, pode, primordialmente, contemplar a grande maioria miserável de cidadãos excluídos.

É bem por isto, que a distribuição de renda/terra e a formação educacional básica na América Latina têm sido insuficientes para atender à demanda populacional.

Estudos efetuados pelo CESIT ${ }^{108}$ (Centro de Estudos Sindicais e de Economia do Trabalho do Instituto de Economia (IE) da Universidade Estadual de CampinasUnicamp) demonstram aspectos interessantes quanto à análise do conteúdo das negociações efetuadas através das convenções coletivas nos subsetores do ramo metalúrgico dos estados de São Paulo, Paraná e Santa Catarina que têm mais experiências em negociações coletivas. Tal estudo minucioso contemplou de maneira categórica as tendências dos contratos coletivos no governo do ex-presidente Fernando Henrique Cardoso após aquelas mencionadas séries de medidas flexibilizantes das relações trabalhistas, nas quais prevaleceu o olhar neoliberal de constrangimento do trabalho em função social contraditória ao devido equilíbrio com o capital, pois políticas macroeconômicas consistentes não são feitas desde o segundo governo FHC.

O sindicalismo corporativo não mais condiz com a realidade da atual conjuntura político-econômica, não existe nem mesmo um comprometimento mais efetivo da maioria dos sindicalistas quanto à mudança, pois as relações de trabalho têm estado arraigadas ao sistema tradicional e conservador que beneficia apenas uma pequena parcela de atores sociais. Um modelo que condiga com nossa realidade não é fácil de conceituar, dadas

\footnotetext{
${ }^{108}$ KREIN, José Dari. Análise do impacto e da efetividade das principais alterações legais no padrão de relações de trabalho no setor metalúrgico, entre 1996-2000. Relatório de pesquisa (preliminar) do projeto "Desenvolvimento Tecnológico, Atividades Econômicas e Mercado de Trabalho nos Espaços Regionais Brasileiros": Projeto de Pesquisa e Formação Técnica DIEESE/CESIT/CNPq. Linha 4 - Mercado e Relações de Trabalho.
} 
nossas peculiaridades, pois requer uma metamorfose na função que o Estado exerce nestas relações e uma maior tomada de consciência na tentativa de modificar a relação explorado/explorador, para, com isto, possibilitar a identificação dos elementos perversos no sistema, permitindo, assim, sua dissolução definitiva.

Desde a edição da CLT que a estrutura do sindicalismo brasileiro permanece inalterada nos seus aspectos essenciais, apesar de transformações profundas nos aspectos econômicos, políticos e sociais que se verificaram nestas últimas cinco décadas. Junto às instituições conservadoras e acomodadas em berço esplêndido, assiste-se a uma degradação das relações de trabalho, que possuem vários motivos, dentre os quais destacamos:

- as imposições de subjugação, desde os tempos coloniais, que nos têm sido impostas pelos grandes interesses capitalistas excludentes, afinados com uma elite submissa àqueles interesses.

- $\quad$ a formulação das instituições jurídicas ligadas ao trabalho (Justiça do Trabalho) dentro do autoritarismo do governo Vargas, não se coaduna com a contemporaneidade das relações de trabalho, pois a dinâmica que as reveste deveria ser acompanhada, mais de perto, por uma comissão mediadora (para cada distrito industrial ou rural) composta por um juiz federal (o que compete à lei), um advogado trabalhista (no papel de árbitro, o que compete aos contratos), um economista do trabalho (competência da análise econômica regional), um representante do sindicato (reivindicações dos trabalhadores como classe social), um delegado sindical (reivindicações dos trabalhadores nos locais de trabalho) e, finalmente, um representante da empresa (decisões das empresas).

- a falta de uma cultura de negociação deveria ser contextualizada através de programas educativos, com ênfase na imparcialidade e confiabilidade, que são os atributos essenciais que devem caracterizar o árbitro, para que a efetivação do processo possa ser satisfatória, principalmente para a instituição de árbitros do setor privado.

Os direitos dos trabalhadores vinham sendo resguardados de maneira exemplar na defesa do hipossuficiente, até meados dos anos 60, como premissa maior do Direito do Trabalho, mas a união de três alicerces (unicidade, imposto sindical e a justiça normativa do trabalho) que têm dado suporte à estrutura corporativa dos sindicatos brasileiros, não 
mais condiz com a dinâmica que tem caracterizado a economia. A arbitragem não é um instrumento que garanta a generalização dos direitos trabalhistas que se vislumbrara no sindicalismo combativo do fim dos anos 70. A maneira pela qual a lei da arbitragem foi instituída não consagra, de maneira enfática, o aprimoramento das relações trabalhistas, mas apenas lança um olhar preocupante nas resoluções dos conflitos comerciais no âmbito geral.

Os pequenos grupos de atores sociais que resistem às mudanças mantêm seu status quo de domínio político-econômico, auferindo benefícios individuais, mas se vêem desorientados com os efeitos das rápidas mudanças na economia política, contrastada com o conservadorismo que não permite vislumbrar um novo paradigma que pudesse resolver as diversas crises que envolvem as respectivas áreas nas relações de trabalho, num mundo cada vez mais contextualizado na política neoliberal. $\mathrm{O}$ fato positivo da arbitragem é o comprometimento "bipartite" com a resolução do conflito e a construção de um novo modelo de relações trabalhistas mais pragmático, em contrapartida à relação tripartite cujas partes recorrem ao poder normativo através do dissídio coletivo para atender seus interesses econômicos sem um maior comprometimento com o resultado, pois, na maior parte dos casos, são interpostos recursos judiciais, o que ocasiona o abarrotamento de processos nos tribunais, invalidando, na realidade, sua eficácia.

A contraposição histórica entre o desenvolvimento econômico e a liberdade sindical remete-nos aos primórdios das relações comerciais em que o capitalismo insiste sustentar, desde a época liberal, ou seja, que a restrição à liberdade sindical é benéfica para o andamento dos negócios. O equilíbrio que seria salutar para estas relações tem sido sempre desfavorável à maioria dos trabalhadores.

A diferença entre países que investiram na educação e países que não investiram como deveriam é que, nos primeiros, a grande maioria dos jovens está ativa primordialmente na função educacional para a sua formação cidadã; enquanto que, nos segundos, os jovens estão ativos nos caminhos da ilegalidade, inclusive no mercado de trabalho informal. Em pesquisas efetuadas pelo autor da tese, entre 2001 e 2006, junto aos jovens que moram nas ruas de São Paulo, Rio de Janeiro, Belo Horizonte e Salvador, concluiu-se que estão na rua marginalizando-se por total falta de opção quanto a sua sobrevivência, pois mais de $93 \%$ dos entrevistados declararam-se infelizes e que não fazia 
parte de seus sonhos estar nesta situação degradante, mas ter um emprego, escola, moradia e lazer.

O Mercosul objetiva, assim como a União Européia, tornar-se um mercado comum, com o estabelecimento de normas trabalhistas comuns aos países-membros, bem como alguns alinhamentos e programas sociais para o eventual deslocamento de trabalhadores. O Nafta, por seu turno, assemelha-se mais a um acordo tácito capitalista que visa unilateralmente atender às prerrogativas do capital internacional. 


\section{B i b l i o g r a f i a}

ALMEIDA, Maria Hermínia Tavares. Difícil caminho: sindicatos e política na construção da democracia. In: O’DONNELL, G. A. \& REIS, F. W. (Eds.) Democracia no Brasil: dilemas e perspectivas. São Paulo: Vértice, 1988, p. 327-367. . O sindicalismo brasileiro entre a conservação e a mudança. In: ALMEIDA, M. H. T. e SORJ, B. (Orgs.) Sociedade e política no Brasil pós-64. 2a edição. São Paulo: Brasiliense, 1984.

AMERICAN PSYCHIATRIC ASSOCIATION. Diagnostic and Statistical Manual on Mental Disorders, 4th edition, (DSM-IV). Washington, D. C.: American Psychiatric Press, 1994.

ANTUNES, Ricardo. O novo sindicalismo. São Paulo: Brasil Urgente, 1991.

BENSUSÁN, Graciela. Estándares laborales después de TLCAN. $1^{\mathrm{a}}$ edición. México, D. F.: Plaza y Valdéz Editores, 1999.

. El modelo mexicano de regulación laboral. México: Facultad Latinoamericana de Ciencias Sociales (FLACSO), 2000.

BOITO, Armando Jr. O sindicalismo brasileiro nos anos 80. São Paulo: Paz e Terra, 1991.

BOK, Dereck C. and DUNLOP, John T. Labor and the American Community. Second Printing. New York: Rockfeller Brothers Fund. Inc./Simon and Schuster, 1970.

BONELLI, R. e FONSECA, R. Ganhos de produtividade e eficiência: resultados novos da economia brasileira. Texto 557. Rio de Janeiro: IPEA, 1998.

CACCIAMALI, M. Cristina. Mudanças estruturais no produto e emprego no Brasil: 1950-1980. São Paulo: FEA-USP, 1988.

. Mercado de trabalho no Brasil na década de 1990: menos empregos, mais política pública. In: VELLOSO, João Paulo dos Reis. (Org.) O Real e o futuro da economia. Rio de Janeiro: José Olympio, 1995.

CARR, Edward Hallett. Que é história? São Paulo: Paz e Terra, 1982.

CARTAS, Jose Maria. El caso mexicano: estabilizacion macroeconomica y reforma estructural del contexto político y social. Buenos Aires: Ed. Kas-Ciedla, 1993. 
CASTRO, Maria Silvia Portella. y WACHENDORFER, Achim. (Coord.) Sindicalismo y globalización: la dolorosa inserción en un mundo incierto. $1^{\text {a }}$ edición. CaracasVenezuela: Editorial Nueva Sociedad, 1998.

CEPAL - Centro de Estudos para a América Latina e o Caribe. Globalização e desenvolvimento. Distribución del ingreso, pobreza y equidad, Actores sociales, ONG's y sociedad civil, Comercio Internacional, Procesos de integración. Período de sessões da CEPAL. Brasília-Brasil, 6 a 10 de Maio de 2002.

CHAUI, Marilena. Convite à filosofia. São Paulo: Ática, 1999.

COGGIOLA, Oswaldo. e KATZ, Cláudio. Novas tecnologias: crítica da atual reestruturação produtiva. São Paulo: Editora Xamã, 1995.

COLLINGWOOD, Robin George. A idéia de história. Tradução de Alberto Freire. Lisboa: Editorial Presença, 1986.

COSTA, Armando Casimiro; FERRARI, Irany. e MARTINS. Melchíades Rodrigues. CLT-LTr 2006. 33ª edição. São Paulo: LTr Editora Ltda., 2006.

CROUCH, Colin. Industrial Relations and European State Traditions. Oxford: Clarendon Press, 1994.

DEDDECA, Claudio Salvadori. Produtividade, emprego e salário na indústria brasileira. In: Anais do XXVII Encontro de Economia - ANPEC. Belém, 1999.

DREIFUSS, René. A internacional capitalista: estratégias e táticas do empresário transnacional 1918-1986. $2^{\mathrm{a}}$ edição. Rio de Janeiro: Espaço e Tempo, 1987.

FERNANDES, Florestan. Nova República. $3^{\text {a }}$ edição. Rio de Janeiro: Jorge Zahar, 1986.

FOUCAULT, Michel. As palavras e as coisas. $6^{\text {a }}$ edição. São Paulo: Martins Fontes, 1992.

FOX, Stephen. Blood and Power: Organized Crime in Twentieth Century America. New York: W. Morrow, 1989.

FREITAS JR., Antônio Rodrigues de. Sindicato: domesticação e ruptura - um estudo de representação sindical no direito brasileiro. São Paulo: Ordem dos Advogados do Brasil, 1989.

FRUNDT, Henry J. "Labor Rights and Hemispheric Trade Agreements". Ensaio apresentado na Associação de Estudos Latino-americanos no XXI Congresso Internacional em Chicago, 1998. 
GARCÍA, Manuel Alonso. Curso derecho del trabajo. $4^{\mathrm{a}}$ edición. Barcelona: Ediciones Ariel, 1973.

GOLDENBERG, Arthur J. AFL-CIO: Labor United. First McGraw-Hill Paperback Edition, 1964.

GORZ, André. Métamorphoses du travail: quête du sens. Critique de la raison économique. Paris: Galilée, 1988.

HABER, Stephen. Development Strategy or Endogenous Process? The Industrialization of Latin America. Working Paper $\mathrm{n}^{\mathrm{o}}$ 269. Stanford Center for International Development, 2005.

HABERMAS, Jurgen. Between Facts and Norms: Contributions to a Discourse Theory of Law and Democracy. Cambridge University Press, 1998.

HEGEL, Georg Wilhelm Friedrich. A razão na história: uma introdução geral à filosofia da história. $2^{\text {a }}$ edição. São Paulo: Centauro Editora, 2001.

HICKS, John. Revolutions in Economics. In: HICKS, John. Classics and Moderns, Collected Essays, Vol. 3. Cambridge: Harvard University Press, 1983.

HIRSCH, Barry T. Unionization and Economic Performance - Evidence on Productivity, Profits, Investment and Growth. Public Policy Sources, number 3. VancouverCanadá: The Fraser Institute, 1997.

HOROWITZ, Carl F. Union Corruption in America: Still a Growth Industry. SpringfieldVirginia: National Institute for Labor Relations Research-NILRR, May 2004.

KERR, Clark. and BAKKE, E. Wight. Unions, Management and the Public. New York: Harcourt Brace and Company, 1948.

KREIN, José Dari. Análise do impacto e da efetividade das principais alterações legais no padrão de relações de trabalho no setor metalúrgico, entre 1996-2000. Relatório de pesquisa (preliminar) do projeto "Desenvolvimento Tecnológico, Atividades Econômicas e Mercado de Trabalho nos Espaços Regionais Brasileiros": Projeto de Pesquisa e Formação Técnica DIEESE/CESIT/CNPq. Linha 4 - Mercado e Relações de Trabalho.

LACEY, H. Is Science Value Free? Values and Scientific Understanding. Londres-Nova York: Routledge, 1999. 
LÓPES, Maria Xelhuantzi. La democracia pendiente: la libertad de asociación sindical e los contratos de protección en México. México: Sindicato de Telefonista de la República Mexicana, 2000.

MATURANA, Humberto R. e VARELA, Francisco J. A árvore do conhecimento. $3^{\mathrm{a}}$ edição. São Paulo: Palas Athena, 2003.

MAYER, Bernard. The Dynamics of Conflict Resolution: a Practioner's Guide. San Francisco: Editor Jossey Bass, 2000. p. 3-93 e 140-212.

MYRDAL, Gunnar. Teoria econômica e regiões subdesenvolvidas. $3^{\mathrm{a}}$ edição. Rio de Janeiro: Editora Saga-GB, 1972.

MORGAN, Chester A. Labor Economics. The Dorsey Press, Inc. Homewood, Illinois. The Dorsey series in Economics, 1962.

NORONHA, Eduardo Garuti. O modelo legislado de relações de trabalho e seus espaços normativos. Tese de Doutoramento em Ciência Política. São Paulo: Universidade de São Paulo, USP, 1998.

. O modelo legislado de relações de trabalho no Brasil. In: VI Encontro Nacional de Estudos do Trabalho, Belo Horizonte, ABET, 1999.

. O modelo legislado de relações de trabalho no Brasil. In: Dados [online]. 2000, vol. 43, n. 2. Disponível em: http://www.scielo.br/scielo.php?script=sci arttext\&pid=S0011$52582000000200002 \& \operatorname{lng}=$ pt\&nrm $=$ iso.

PETERS, Edward and PRASOW, Paul. Arbitration and Collective Bargaining: Conflict Resolution in Labor Relations. New York: McGraw-Hill Book Company, 1970.

POLANYI, Karl. The Great Transformation: The Political and Economic Origins of Our Time. Boston: Beacon Press, 1944.

PRESIDENT's Commission on Organized Crime. In the Matter of Roy L. Williams, a Witness Subpoenaed by the President's Commission on Organized Crime. In The Edge $=$ Organized Crime, Business and Labor Unions - Appendix. Washington, D.C.: U. S. Gob Printing Office, 1985.

RABE, Stephen. USA Intervention in British Guiana: A Cold War History. University of North Carolina. Chapel Hill, 2004.

RACKETEER INFLUENCED AND CORRUPT ORGANIZATIONS ACT (RICO): A Manual for Federal Prosecutors. U. S. Department of Justice. Fourth Revised Edition. Washington D. C.: July 2000. 
REVUELTAS, José. El luto humano. México: Editorial México, 1943.

ROBINSON, Ian. North American Trade As If Democracy Mattered: What's Wrong with NAFTA and What Are the Alternatives? Canadian Centre for Policy Alternatives and International Labor Rights Education and Research Fund, 1993.

ROBINSON, Ian; PRASAD, Monica; KIMELDORF, Howard; MEYER, Rachel. Consumers of the World Unite: a Market-based Response to Sweatshops. Labor Studies Journal, Vol. 29. Published for the United Association for Labor Education, West Virginia University. Morgantown: West Virginia University Press, 2004, p. $57-80$.

RODRIGUES, Iram J. O novo sindicalismo vinte anos depois. Petrópolis: Vozes, 1999.

ROMITA, Arion Sayão. Sindicalização por categoria. In: Revista LTr, São Paulo, vol. 59, n. 3, mar.1995, p. 307.

SANTOS, Enoque Ribeiro dos; SILVA, Otávio Pinto; CRAVO, Silmara Cosme; FIORAVANTE, Tamira Maira. (Orgs.) Temas controvertidos do direito do trabalho no cenário nacional e internacional. São Paulo: LTr Editora Ltda., 2006.

SCHLESINGER, Arthur M. New Viewpoints in American History. New York: Macmillan, 1922.

SCHLAGHECK, James L. The Political, Economic and Labor Climate in Mexico. Pennsylvania University, 1989.

SCHMITTER, P. Still the Century of Corporativism? In: Review of Politics, vol. 36, 1974, p. 85-131.

SCHUMPETER, Joseph A. Business Cycles: a Theoretical, Historical and Statistical Analysis of the Capitalist Process. New York: McGraw-Hill, 1939.

SCIPES, Kim. Labor Imperialism Redux? The AFL-CIO's Foreign Policy Since 1995, Monthly Review, May 2005. http://www.monthlyreview.org/0505scipes.htm.

SILVA, Edmar Luís. Compreender a vida, fundamentar a história: a crítica da razão histórica em Wilhelm Dilthey (1833-1911). Dissertação de Mestrado em História. Orientador: Prof. Dr. José Carlos Reis. Departamento de História Faculdade de Filosofia e Ciências Humanas da UFMG. Belo Horizonte, 2006.

SIMKIN, William E. Mediation and the Dynamics of Collective Bargaining. Washington, D. C.: The Bureau of National Affairs Inc., 1971.

SINGER, P. Globalização e desemprego. São Paulo: Contexto, 1999. 
SIQUEIRA Neto, J. F. O. e OLIVEIRA, M. A. Contrato coletivo de trabalho: possibilidades e obstáculos à democratização das relações de trabalho no Brasil. In: OLIVEIRA, C. A. B. de. e MATTOSO, J. E. L. (Org.). Crise e trabalho no Brasil. São Paulo: Scritta, 1996.

SKINNER, B. F. Ciência e comportamento humano. $2^{\text {a }}$ edição. São Paulo: Edart Livraria Editora Ltda., 1974.

SLATER, Joseph. Public Workers: Government Employee Unions, the Law and the State, 1900-1962. Cornell University-USA, 2004.

SMOOT, Dan. (1962) The Invisible Government. Published by The Dan Smoot Report Inc. Dallas-Texas: First Electronic Printing, May 2004.

SOMBART, Werner. Pourquoi le Socialisme n'Existe-t-il pas aux États-Unis? FranceParis: P.U.F., 1992.

SUM, Andrew; HARRINGTON, Paul; TOBAR, Paulo; KHATIWADA, Ishwar. The Unprecedented Rising Tide of Corporate Profits and the Simultaneous Ebbing of Labor Compensation: Gainers and Losers from the National Economic Recovery in 2002 and 2003. Center for Labor Market Studies. Massachusetts: Northeastern University Boston, March 2004.

USHER, Dan. The Price Mechanism and the Meaning of National Income Statistics. London: Oxford University, 1976.

VERSIANI, Flávio Rabelo. e SUZIGAN, Wilson. O processo de industrialização no Brasil: uma visão geral. Brasília: Departamento de Economia da UnB, 1990.

WRIGHT, Fernanda Pacca de Almeida. Desafio americano à preponderância britânica no Brasil 1808-1850. Publicação conjunta do Conselho Federal de Cultura e do Instituto Histórico e Geográfico Brasileiro. Rio de Janeiro: Departamento de Imprensa Nacional/GB, 1972.

ZYLBERSTAJN, H. É preciso esperar pela reforma trabalhista? In: Informações Fipe. São Paulo, Fipe-USP, n. 159, abr. 1997.

.; PASTORE, José. A administração do conflito trabalhista no Brasil. $3^{a}$ edição. São Paulo: Editora Ipê, 1988. 


\section{A N E X O S}

\section{E N T R E V I S T A S}

1. Prof. Dr. Ian Robinson - eian@umich.edu

Vice-presidente do Conselho da Universidade de Michigan, campus de Ann Harbor, que organiza as conferencias das organizações trabalhistas. Ele leciona economia política internacional comparada no Departamento de Sociologia com ênfase nas relações trabalhistas. Idealizador da urgência de mudanças sociais globais (Social Changes) para a melhora e equilíbrio do desenvolvimento humano. Ann HarborEUA. Setembro de 2004.

2. Profa. Dra. Graciela Bensusan e assistente Profa. Soledad Aragón solarmartinez@yahoo.com

Facultad Latinoamericana de Ciencias Sociales (FLACSO)

Camino al Ajusco, 377 - Col. Heroes de Padierna, Ciudad de México.

Outubro de 2004.

3. Centro de Apoyo a Trabajadores (CAT)

Avenida Reforma, 903-3, Colonia - Centro - Caixa Postal 72000

Tel. (052-222) - 246-0598 - Celular 750-1215.

Srta. Blanca Velásquez Diaz - Coordenadora e Relações Exteriores

Srta. Gabriela Cortez Cabrera (Cultura e Finanças)

Sr. Ivan de Erique. (Associado)

Ciudad de Puebla de Los Angeles - México. Outubro de 2004.

4. Entrevista com a Sra. Carolyn Kazdin - aflcio@uol.com.br

Representante no Brasil do Solidary Center - AFL/CIO.

Avenida Paulista, 1159, cj. 215 - Tel. 289.2921. Maio de 2002

5. Profa. Dra. Ceci Juruá. É professora de economia com especialização em Desenvolvimento e Planejamento Econômico na França, Conselheira do CRE/RJ. Membro do "Outro Brasil”, programa do Laboratório de Políticas Públicas (LPP) da Universidade Estadual do Rio de Janeiro dedicado ao estudo de economia política, política internacional, movimentos sociais e sindicais. Agosto de 2005.

6. Prof. Dr. Gus Cochram. Professor de Ciências Políticas. Advogado com especialização em relações de trabalho.

Agnes Scott College - Decatur, Geórgia, USA 30030

Tel (404) 471-6216. Março de 2006 e Outubro de 2007, em São Paulo.

7. Sindicato dos Trabalhadores em Transportes Fluviais do São Francisco (SINDIFLU) Sr. Helder Braga de Melo (presidente)

Av. São Francisco, 1588, Pirapora-MG.- Tel (038) 3741-1391.Janeiro de 2005. 
PROGRAMAS DE ÁUdIOS EM RÁDIOS - INTERNET

1. "Labor Express" programa de rádio na cidade de Chicago (USA), conduzido por Jerry Mead na WLUW Radio, entrevista com Kim Scipes. In: The Fight to Transform AFL-CIO Foreign Policy.

Disponível em www.laborexpress.org/AudioFiles/kimscipes.mp3. Acesso em 3 de março de 2006.

2. "Pacifica Radio Foundation" Kim Scipes, Ph.D., Assistant Professor of Sociology in the Department of Social Sciences at Purdue University North Central speak with Dennis Bernstein about the international foreign policy of the AFL-CIO's Solidarity Center. Disponibilizada em http://www.pacifica.org/programs/flashpoints/flashpoints_060613.html Acesso em 7 de novembro de 2006 às 10:15am.

3. "Democracy Now". Entrevista com Kim Scipes, prof. de Sociologia na Universidade de Purdue e reporter trabalhista, e Fred Hirsch, vice-presidente do Plumber Union de San Jose (California) e ativista da Coalisão de solidariedade na América Latina. http://www.archive.org/download/dn2005-0726/dn20050726-64kb.mp3. Acesso em 7 de novembro de 2006 às 10:00am. 


\section{A P Ê N D I C E}

\section{Capítulo III - ConTrato Coletivo de TrabalHo ${ }^{109}$}

Artigo 386 - Contrato Coletivo de Trabalho é o convênio celebrado entre um ou vários sindicatos de trabalhadores e um ou vários patrões, ou um ou vários sindicatos de patrões, com objeto de estabelecer as condições segundo as quais se deve prestar o trabalho em uma ou mais empresas ou estabelecimentos.

Artigo 387 - O patrão que empregue trabalhadores membros de um sindicato terá obrigação de celebrar com este, quando o solicitar, um Contrato Coletivo.

Se o patrão se negar a assinar o contrato, poderão os trabalhadores exercitar o direito de greve consignado no artigo 450.

Artigo 388 - Se dentro da mesma empresa existem vários sindicatos, observar-se-ão as normas seguintes:

I. se concorrerem sindicatos de empresa ou industriais ou uns e outros, o Contrato Coletivo se celebrará com o que tenha maior número de trabalhadores dentro da empresa;

II. se concorrerem sindicatos corporativos, o Contrato Coletivo se celebrará com o conjunto dos sindicatos majoritários que representem às profissões, sempre que fiquem de acordo. Em caso contrário, cada sindicato celebrará um Contrato Coletivo para sua profissão; e

III. se concorrerem sindicatos indústria, poderão os primeiros celebrar um Contrato Coletivo para sua profissão, sempre que o número de seus afiliados seja maior que o dos trabalhadores da mesma profissão que formem parte do sindicato de empresa ou de indústria.

Artigo 389 - A perda da maioria a que se refere o artigo anterior, declarada pela Junta de Conciliação e Arbitragem, produz a da titularidade do Contrato Coletivo de Trabalho.

Artigo 390 - O Contrato Coletivo de Trabalho deverá celebrar-se por escrito, sob pena de nulidade. Serão feitas 3 cópias, entregando um exemplar a cada uma das partes e se depositará o outro na Junta de Conciliação e Arbitragem ou na Junta Federal ou Local de Conciliação que, depois de anotar data e hora da apresentação do documento, o remeterá à Junta Federal ou Local de Conciliação e Arbitragem.

${ }^{109}$ Ley Federal Del Trabajo - LFT. (Tradução do Autor) 
O contrato sortirá efeitos da data e hora de apresentação do documento, salvo que as partes tivessem convencionado em uma data distinta.

Artigo 391 - O Contrato Coletivo conterá:

I. os nomes e domicílios dos contratantes;

II. as empresas e estabelecimentos que abranjam;

III. sua duração ou a expressão de ser por tempo indeterminável ou para obra determinada;

IV. as jornadas de trabalho;

V. os dias de descanso e férias;

VI. o montante dos salários;

VII. as cláusulas relativas à capacitação ou adestramento dos trabalhadores na empresa ou estabelecimentos que compreenda;

VIII. disposições sobre a capacitação ou adestramento inicial que se deva repartir a quem vá ingressar em trabalhar à empresa ou estabelecimento;

IX. as bases sobre a integração e funcionamento das Comissões que devam integrarse de acordo com esta lei, e

$\mathrm{X}$. as demais estipulações que convenham as partes.

Artigo 392 - Nos contratos coletivos poderá estabelecê-la organização de comissões mistas para o cumprimento de determinadas funções sociais e econômicas. Suas resoluções serão executadas pelas Juntas de Conciliação e Arbitragem, nos casos em que as partes as declarem obrigatórias.

Artigo 393 - Não produzirá efeitos de Contrato Coletivo o convênio ao que falte a determinação dos salários. Se faltarem as estipulações sobre jornada de trabalho, dias de descanso e férias, aplicar-se-ão as disposições legais.

Artigo 394 - O Contrato Coletivo não poderá consertar-se em condições menos favoráveis para os trabalhadores que as contidas em contratos vigentes na empresa ou estabelecimento.

Artigo 395 - No Contrato Coletivo poderá estabelecer-se que o patrão admitirá exclusivamente como trabalhadores a quem seja membro do sindicato contratante. Esta cláusula e quaisquer outras que estabeleçam privilégios em seu favor, não poderão aplicar-se em prejuízo dos trabalhadores que não formem parte do sindicato e que já emprestem seus serviços na empresa ou estabelecimento com antecedência à data em que o sindicato solicite a celebração ou revisão do Contrato Coletivo e a inclusão nele da cláusula de exclusão. 
Poderá também se estabelecer que o patrão separará do trabalho aos membros que renunciem ou sejam expulsos do sindicato contratante.

Artigo 396 - As estipulações do Contrato Coletivo se estendem a todas as pessoas que trabalhem na empresa ou estabelecimento, embora não sejam membros do sindicato que o tenha celebrado, com a limitação consignada no artigo 184.

Artigo 397 - O Contrato Coletivo por tempo determinado ou indeterminável, ou para obra determinada, será revista total ou parcialmente, de conformidade com o disposto no artigo 399.

Artigo 398 - Na revisão do Contrato Coletivo observar-se-á às normas seguintes:

I. se se celebrou por um só sindicato de trabalhadores ou por um só patrão, qualquer das partes poderá solicitar sua revisão;

II. se se celebrou por vários sindicatos de trabalhadores, a revisão se fará sempre que os solicitantes representem o cinqüenta e um por cento da totalidade dos membros dos sindicatos, pelo menos, e

III. se se celebrou por vários patrões, a revisão se fará sempre que os solicitantes tenham o cinqüenta e um por cento da totalidade dos trabalhadores afetados pelo contrato, pelo menos.

Artigo 399 - A solicitude de revisão deverá fazer-se, pelo menos, sessenta dias antes:

I. do vencimento do Contrato Coletivo por tempo determinado, se este não for major de dois anos;

II. do transcurso de dois anos, se o contrato por tempo determinado tem uma duração maior, e

III. do transcurso de dois anos, nos casos de contrato por tempo indeterminável ou por obra determinada.

Para o cômputo deste término se atenderá ao estabelecido no contrato e, em seu defeito, à data do depósito.

Artigo 399 bis - Sem prejuízo do que estabelece o artigo 399, os contratos coletivos serão revisados cada ano no que se refere aos salários em efetivo por cota diária.

A solicitude desta revisão deverá fazer-se pelo menos trinta dias antes do cumprimento de um ano transcorrido da celebração, revisão ou prorrogação do Contrato Coletivo.

Artigo 400 - Se nenhuma das partes solicitou a revisão nos términos do artigo 399 ou não se exercitou o direito de greve, o Contrato Coletivo se prorrogará por um período.

A Junta de Conciliação e Arbitragem resolverá a respeito do cancelamento de seu registro. 
Artigo 401 - O Contrato Coletivo de Trabalho se encerra:

I. Por mútuo consentimento;

II. Por terminação da obra; e

III. Nos casos do capítulo VIII deste Título, por fechamento da empresa ou estabelecimento, sempre que neste último caso, o Contrato Coletivo se aplique exclusivamente no estabelecimento.

Artigo 402 - Se assinado um Contrato Coletivo, um patrão se separa do sindicato que o celebrou, o contrato regerá, não obstante, as relações daquele patrão com o sindicato ou sindicatos de seus trabalhadores.

Artigo 403 - Nos casos de dissolução do sindicato de trabalhadores titular do Contrato Coletivo ou de término deste, as condições de trabalho continuarão vigentes na empresa ou estabelecimento.

\section{Capítulo IV - CONTRATO-LEI (CONTRATO COLETIVO OBRIGATÓRIO)}

Artigo 404 - Contrato-Lei é o convênio celebrado entre um ou vários sindicatos de trabalhadores e vários patrões, ou um ou vários sindicatos de patrões, com objeto de estabelecer as condições segundo as quais deve emprestar o trabalho em um ramo determinado da indústria, e declarado obrigatório em um ou vários Estados, em uma ou várias zonas econômicas que abranjam um ou mais dos ditos Estados, ou em todo o território nacional.

Artigo 405 - Os Contratos-Lei podem celebrar-se para indústrias de jurisdição federal ou local.

Artigo 406 - Podem solicitar a celebração de um Contrato-Lei os sindicatos que representem as duas terceiras partes dos trabalhadores sindicalizados, pelo menos, de um ramo da indústria em um ou vários Estados, em uma ou mais zonas econômicas, que abranja uma ou mais dos ditos Estados ou em todo o território nacional.

Artigo 407 - A solicitude se apresentará à Secretaria do Trabalho e Previsão Social, se se referir a duas ou mais Entidades Federativas ou a indústrias de jurisdição federal, ou ao Governador do Estado ou Território ou Chefe do Departamento do Distrito Federal, se se tratar de indústrias de jurisdição local.

Artigo 408 - Os solicitantes justificarão que satisfazem o requisito de maioria mencionado no artigo 406.

Artigo 409 - A Secretaria do Trabalho e Previsão Social, o Governador do Estado ou Território ou o Chefe do Departamento do Distrito Federal, depois de verificar o 
requisito de maioria, se a seu julgamento é oportuna e benéfica para a indústria a celebração do Contrato-Lei, convocará uma convenção dos sindicatos de trabalhadores e dos patrões que possam resultar atingidos.

Artigo 410 - A convocatória se publicará no Diário Oficial da Federação ou no periódico oficial do Estado e nos periódicos ou pelos meios que se julguem adequados e assinalará o lugar onde tenha que celebrar a convenção e a data e hora da reunião inaugural. A data da reunião será assinalada dentro de um prazo não menor de que trinta dias.

Artigo 411 - A convenção será presidida pelo Secretário do Trabalho e Previsão Social, ou pelo Governador do Estado ou Território ou pelo Chefe do Departamento do Distrito Federal, ou pelo representante que ao efeito designem.

A convenção formulará seu regulamento e integrará as comissões que julgue conveniente.

Artigo 412 - O Contrato-Lei conterá:

I. Os nomes e domicílios dos sindicatos de trabalhadores e dos patrões que concorreram à convenção;

II. A Entidade ou Entidades Federativas, a zona ou zonas que abranja ou a expressão de reger em todo o território nacional;

III. Sua duração, que não poderá exceder de dois anos;

IV. As condições de trabalho assinaladas no artigo 391, frações IV, V, VI e IX;

V. As regras conforme as quais se formularão planos e programas para implantação da capacitação e o adestramento no ramo da indústria de que se trate; e,

VI. As demais estipulações que convenham as partes.

Artigo 413 - No Contrato-Lei poderá se estabelecer cláusulas a que se refere o artigo 395. Sua aplicação corresponderá ao sindicato administrador do Contrato-Lei em cada empresa.

Artigo 414 - O convênio deverá ser aprovado pela maioria dos trabalhadores a que se refere o artigo 406 e pela maioria dos patrões que tenham a seu serviço a mesma maioria de trabalhadores.

Aprovado o convênio nos términos do parágrafo anterior, o Presidente da República ou o Governador do Estado ou Território, publicarão no Diário Oficial da Federação ou no periódico oficial da Entidade Federativa, declarando o Contrato-Lei no ramo da indústria considerada, para todas as empresas ou estabelecimentos que existam ou se estabeleçam no futuro na Entidade ou Entidades Federativas, na zona ou zonas que abranja ou em todo o território nacional. 
Artigo 415 - Se o Contrato Coletivo tiver sido celebrado por uma maioria de duas terceiras partes dos trabalhadores sindicalizados de determinado ramo da indústria, em uma ou várias Entidades Federativas, em uma ou várias zonas econômicas, ou em todo o território nacional, poderá ser elevado à categoria de Contrato-Lei, prévio cumprimento dos requisitos seguintes:

I. A petição deverá apresentar-se pelos sindicatos de trabalhadores ou pelos patrões ante a Secretaria do Trabalho e Previsão Social, o Governador do Estado ou Território ou o Chefe do Departamento do Distrito Federal, de conformidade com o disposto no artigo 407;

II. Os sindicatos de trabalhadores e os patrões comprovarão que satisfazem o requisito de maioria referenciado no artigo 406;

III. Os peticionários acompanharão a sua solicitude cópia do contrato e assinalarão a autoridade ante a que esteja depositado;

IV. A autoridade que receba a petição, depois de verificar o requisito da maioria, ordenará sua publicação no Diário Oficial da Federação ou no periódico oficial da Entidade Federativa, e assinalará um término não menor de quinze dias para que se formulem oposições;

V. Se não se formula oposição dentro do término disposto na convocatória, o Presidente da República ou o Governador do Estado ou Território, declarará obrigatório o Contrato-Lei, de conformidade com o disposto no artigo 414; e

VI. Se dentro do prazo disposto na convocatória se formula oposição, observar-se-ão as seguintes normas:

a. Os trabalhadores e os patrões disporão de um limite de quinze dias para apresentar por escrito suas observações, acompanhadas das provas que as justifiquem.

b. O Presidente da República ou o Governador do Estado ou Território, tomando em consideração os dados do expediente, poderá declarar a obrigatoriedade do Contrato-Lei.

Artigo 416 - O Contrato-Lei produzirá efeitos a partir da data de sua publicação no Diário Oficial da Federação, ou no periódico oficial da Entidade Federativa, salvo se a convenção assinalar uma data distinta.

Artigo 417 - O Contrato-Lei se aplicará, não obstante, a qualquer disposição em contrário contida no Contrato Coletivo que a empresa tenha celebrado, salvo naqueles pontos em que estas estipulações sejam mais favoráveis ao trabalhador. 
Artigo 418 - Em cada empresa, a administração do Contrato-Lei corresponderá ao sindicato que represente dentro dela o maior número de trabalhadores. A perda da maioria declarada pela Junta de Conciliação e Arbitragem produz a da administração daquele contrato.

Artigo 419 - Na revisão do Contrato-Lei se observará às normas seguintes:

I. Poderão solicitar a revisão os sindicatos de trabalhadores ou os patrões que representem as maiorias assinaladas no artigo 406;

II. A solicitude apresentar-se-á à Secretaria do Trabalho e Previsão Social, ao Governador do Estado ou Território ou ao Chefe do Departamento do Distrito Federal, noventa dias antes do vencimento do Contrato-Lei, pelo menos;

III. A autoridade que receba a solicitude, depois de verificar o requisito de maioria, convocará aos sindicatos de trabalhadores e aos patrões abrangidos a uma convenção, que se regerá pelo disposto no artigo 411; e

IV. Se os sindicatos de trabalhadores e os patrões chegarem a um acordo, a Secretaria do Trabalho e Previsão Social, o Governador do Estado ou Território ou o Chefe do Departamento do Distrito Federal, ordenará sua publicação no Diário Oficial da Federação ou no periódico oficial da Entidade Federativa. As reformas sortirão efeitos a partir do dia de sua publicação, salvo se a convenção assinalar uma data distinta.

Artigo 419 bis - Os Contratos-Lei serão revisados a cada ano no que se refere aos salários reais por cota diária.

A solicitude desta revisão deverá fazer-se pelo menos sessenta dias antes do cumprimento de um ano, transcorrido da data em que surtam efeitos a celebração, revisão ou prorrogação do Contrato-Lei.

Artigo 420 - Se nenhuma das partes solicitou a revisão ou não se exercitou o direito de greve, o Contrato-Lei se prorrogará por um período igual ao que se fixou para sua duração.

Artigo 421 - O Contrato-Lei terminará:

I. Por mútuo consentimento das partes que representem a maioria a que se refere o artigo 406; e

II. Se ao concluir o procedimento de revisão, os sindicatos de trabalhadores e os patrões não chegarem a um acordo, salvo aqueles que exercitarem o direito de greve. 


\section{S I G L A S}

\begin{tabular}{|c|c|}
\hline AFL-CIO & American Federation of Labor - Council of Industrial Organization \\
\hline BLS & Bureau of Labor Statistics \\
\hline CAT & Centro de Apoyo a Trabajadores \\
\hline CLASC & Confederação Latino Americana de Sindicatos Cristãos \\
\hline CLAT & Central Latino-Americana de Trabalhadores (ex-CLASC) \\
\hline CMT & Confederação Mundial de Trabalhadores (federação católica) \\
\hline COPARMEX & Confederação Patronal da República Mexicana \\
\hline COR & Confederação Obreira Revolucionária \\
\hline CEPAL & Comissão Econômica para a América Latina e o Caribe \\
\hline СCT & Contrato Coletivo de Trabalho \\
\hline $\mathrm{CP}$ & Contrato de Proteção \\
\hline CROC & Confederação Regional de Obreiros e Campesinos \\
\hline CROM & Confederação Regional Obreira Mexicana \\
\hline CT & Congreso del Trabajo; Labor Congress \\
\hline CTM & Confederação de Trabalhadores Mexicanos (a mais poderosa federação) \\
\hline EZLN & Exército Zapatista de Libertação Nacional \\
\hline FAT & Frente Autentico del Trabajo \\
\hline FNAP & Frente Nacional de Ação Popular \\
\hline FORO & Fórum do Sindicalismo (foristas, frente a crise nacional) \\
\hline FESEBES & Federação de Sindicatos de Bens e Serviços \\
\hline FGTS & Fundo de Garantia por Tempo de Serviço \\
\hline DIEESE & Departamento Intersindical de Estatística e Estudos Sócio-Econômicos \\
\hline IBGE & Instituto Brasileiro de Geografia e Estatística \\
\hline ICT & Instituto Cultural do Trabalho \\
\hline JFCA & Junta Federal de Conciliacion y Arbitraje \\
\hline $\mathrm{JOC}$ & Juventude Obreira Cristã \\
\hline IEDI & Instituto de Estudos para o Desenvolvimento Industrial \\
\hline NAFTA & North American Free Trade Agreement \\
\hline NAO & National Administrative Office (US Dept of Labor) \\
\hline NGO & Non-Governmental Organization (ONG) \\
\hline NLRA & National Labor Relations Act \\
\hline NLRB & National Labor Relations Board \\
\hline OIT & Organização Internacional do Trabalho \\
\hline PAN & Partido de Ação Nacional (oposição conservadora) \\
\hline PRD & Partido Revolucionário Democrático (orientação ideológica de esquerda) \\
\hline PRI & Partido Revolucionário Institucional \\
\hline PRT & Partido Revolucionário dos Trabalhadores \\
\hline PEA & População Economicamente Ativa \\
\hline REMALC & Rede Mexicana Contra o NAFTA \\
\hline SNTE & Sindicato Nacional de Trabalhadores na Educação \\
\hline SNTIHA & $\begin{array}{l}\text { Sindicato Nacional de Trabalhadores da Indústria de Ferro e Aço (primeiro } \\
\text { sindicato da Frente Autentico del Trabajo-FAT) }\end{array}$ \\
\hline SSM & Secretaria Social do México \\
\hline STERM & Sindicato Trabalhadores em Eletricidade da República do México \\
\hline STFRM & Sindicato Trabalhadores Ferroviários da República do México \\
\hline SUTERM & $\begin{array}{l}\text { Sindicato Único dos Trabalhadores em Eletricidade da República do México } \\
\text { (fusão compulsória emanada pelo governo) }\end{array}$ \\
\hline UNT & União Nacional de Trabalhadores \\
\hline UOI & Unidade Obreira Independente (federação de sindicatos independentes) \\
\hline
\end{tabular}

